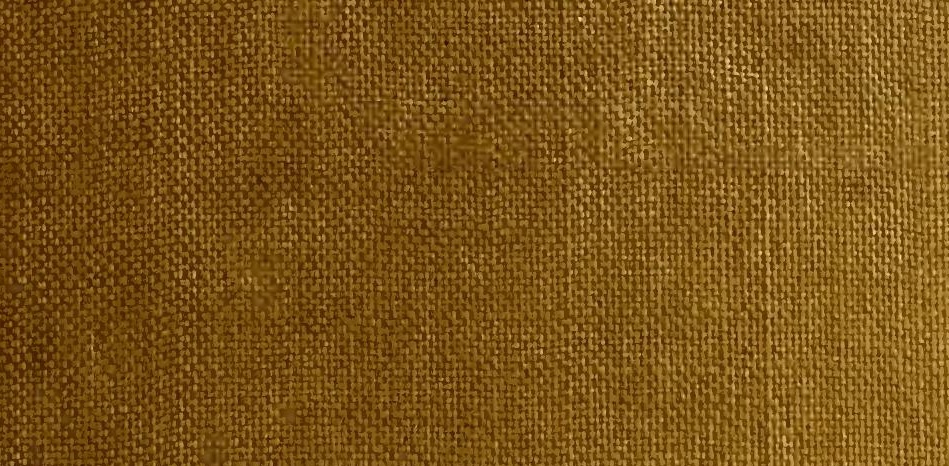







\title{
TRAVELS
}

\author{
To \\ T I M B U C T
}

VOL. II. 


\section{LIST OF PLATES.}

Page,

I.-Portrait of the Author. To face title Vol. I.

II.-General map. To face title Vol. II.

III-Itinerary map. Vol. II. . . . . . . . I

IV.-A woman of Timbuctoo . . . . . . . 61

V.-M. Caillié meditating upon the Koran, and

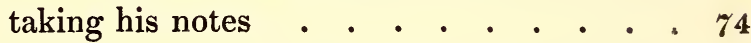

IV.-Plan of the great mosque of Timbuctoo, and

a view of it taken from the E. N. E. . . 79

V.-Details of the great mosque of Timbuctoo. . 73

V1.-View of part of the town of Timbuctoo, taken

from the summit of a hill to the E. N. E. 75

LONDON :

FRINTFD BY G. SCHULZE, 13, POLAND STREET. 



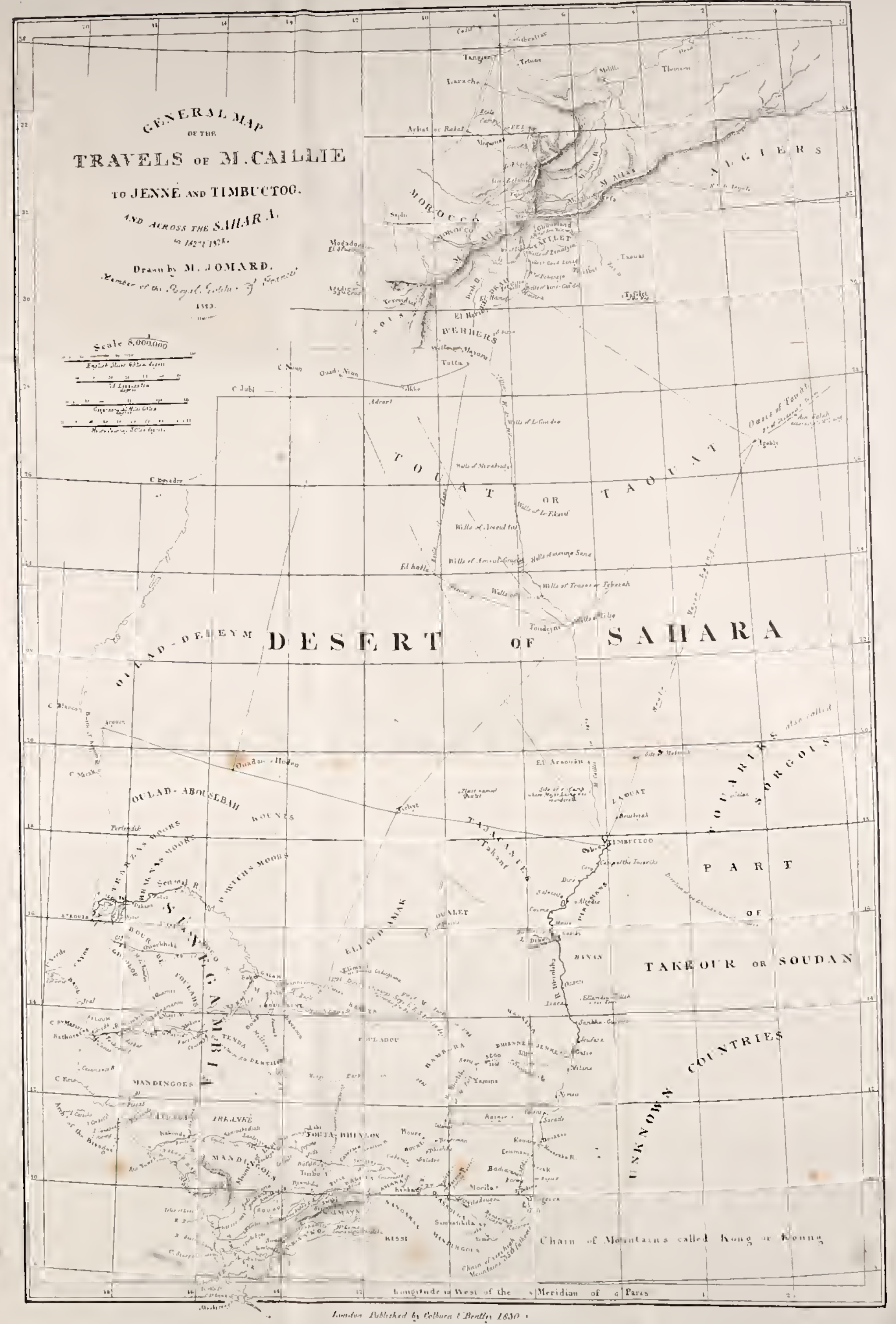





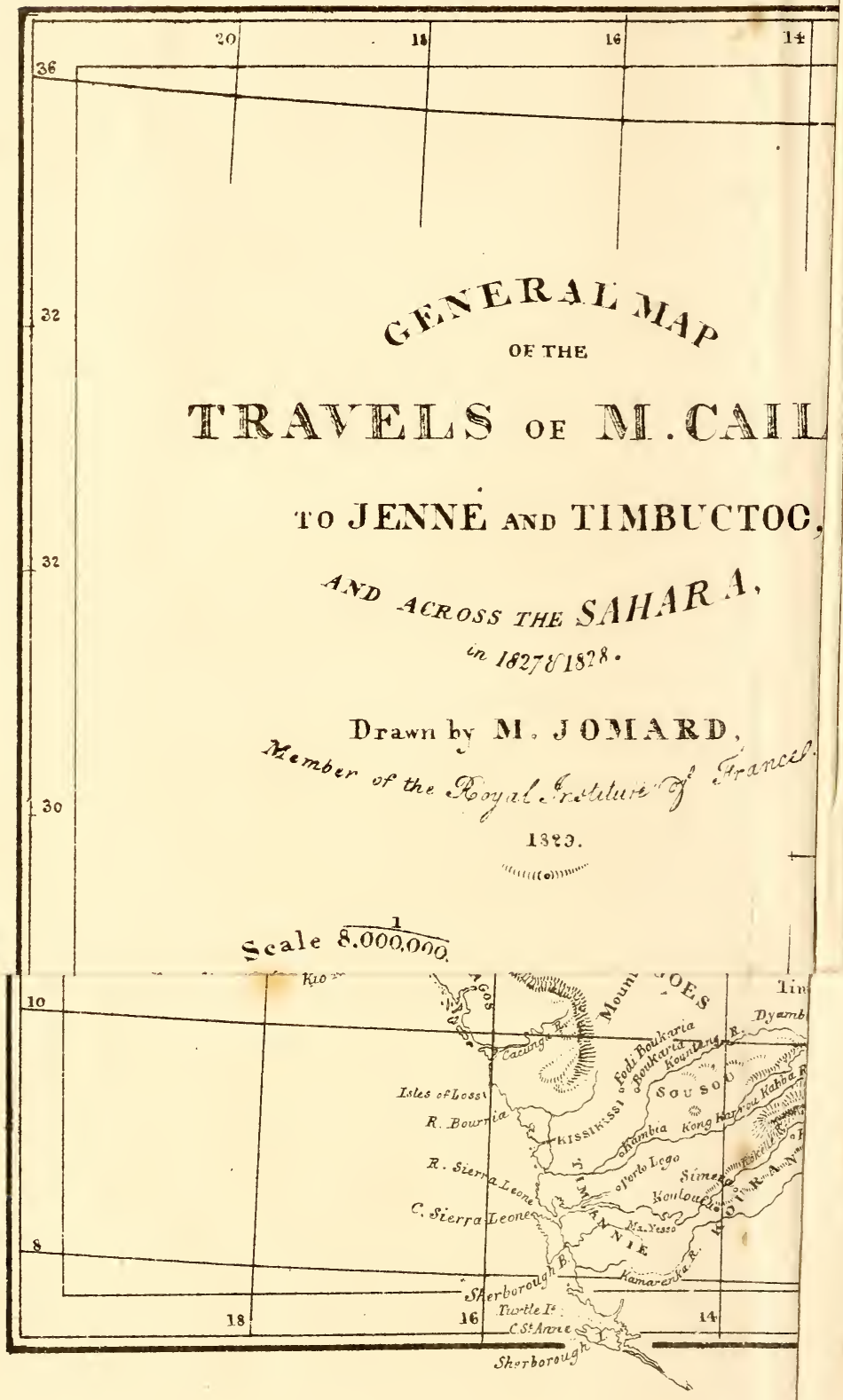




\section{T R A V E L S}

THROUGH

\section{CENTRALAFRICA}

TO

\section{T I M B U C T O O;}

AND

ACROSS THE GREAT DESERT, TO MOROCCO ;

PERFORMED IN THE YEARS 1824-1828.

BY RÉNE CAILLIÉ.

IN TWO VOLUMES.

VOL. II.

LONDON :

HENRY COLBURN AND RICHARD BENTLEY, NEW BURLINGTON STREET.

1830. 



\section{P R E F A C E.}

1 offer, at length, to the public the narrative of my travels in the interior of Africa, which should have appeared long since; several causes have, however, concurred during the fifteen months that have elapsed since my return to my native soil, to retard its publication till the present time. I have brought home, from the regions I have traversed, only fugitive and very laconic notes, written in haste and trepidation: they would have been inexorable evidences against me, had $I$ been surprised tracing unknown characters, and unveiling as it were to the Whites the mysteries of these countries. In Africa, especially in those districts occupied by the Foulahs and the Moors, religious hypocrisy in a stranger is the most flagrant of outrages, and it were a hundred times better to pass there for a Christian, than for a false Mahometan; so that if my mode of travelling had its advantages, which its success has proved, it was also attended with terrible inconveniences. I carried always in my wallet a sentence of death, and how often was that wallet necessarily confided to the hands of enemies! On my arrival in Paris, the notes, written mostly in pencil, were found so faint and so much effaced by time, my wanderings, and my 
ill fortune, that it required all the tenacity and the scrupulous fidelity of my memory to restore and reproduce them as the basis of my observations and the materials of my narrative.

But that scrupulous fidelity which should always distinguish the compilation of travels, and which I consider the principal merit of mine, demanded that I should consecrate to this work the time necessary to ascertain that I have omitted nothing essential, and to arrange the facts in the exact order in which I had observed and noted them. Another not less legitimate cause of delay arose from a long and dangerous illness which seized me some months after my arrival in France, and exhausted the strength which was left me by the long continued fatigues and privations of a seventeen months' journey over those burning sands so frequently fatal to our European travellers. To these causes must also be added the extent of my materials, my want of initiation into the art of composition in the most difficult and delicate of languages, and the resolution $I$ had formed to avoid having recourse to a more experienced pen, except for the correction of those errors of style which would naturally escape mine; for I was desirous of offering to the public a composition as entirely my own as the observations on which it was founded; a composition which, however deficient in studied elegance, should at least be simple, clear, and frank, describing the exact extent of iny travels and exhibiting the traveller under his peculiar traits. With regret I acknowledge that important observations upon 
the political and religious institutions, and upon the manners and customs of the people amongst whom I have sojourned, will not be found here; even had my prior studies directed my mind to this species of reflections, the scanty resources at my disposal, and the consequent necessity of a rapid passage, did not permit my residence in any place for a sufficient length of time to furnish a solid foundation for such researches. My principal object was to collect carefully and accurately all the facts, of whatsoever nature, which fell under my inspection, and especially to notice whatever appeared conducive to the improvement of geography and of our commerce with Africa.

A long stay in our establishments of Senegal, and perhaps also, my own experience, had taught me how much this commerce, which had so long languished, needed new markets and new connections in the interior; but to form these new connections, to impose on the distant population a tribute to our industry, new discoveries were necessary; and increased geographical knowledge was indispensable to enable the government to extend sufficient encouragement to our mercantile establishments on the coast. A strong persuasion of this necessity, of this urgent need, under which our African commerce labours, became in a manner the soul of my inquiries, particularly in a certain portion of my travels. I was convinced that our colonial and all our commercial relations must sooner or later be powerfully influenced by clear and positive information, drawn from the fountain head, and deposited 
with the government of a king, the zealous and enlightened protector of interests so important, and so nearly affecting, at the present period, the prosperity, and perhaps even the internal tranquillity of the kingdom.

Have $I$ been fortunate enough to realize in this respect the wishes I had formed, the hopes which, in common with my former compatriots of Senegal, I had dared to conceive, of fulfilling this part of the task which I undertook, and of thus paying my tribute to the government of my country? Let my natural judges, with whom the fruits of my researches are deposited, and let the success of future enterprizes, incited by mine, answer this question for me. It is not for me to estimate the progress which geographical and natural science may owe to my travels. I must leave it to be appreciated by those who so worthily represent them in the capital of the civilized world, and the possession of whose knowledge and talents would have been so delightful, and above all so useful to me, when day after day I found myself alone and left to my own feeble resources in a world as yet unknown to, and unexplored by curious and scientific Europe. Armed with the knowledge and the instruments for which we are indebted to them, I might have hoped to have more fully accomplished the wishes of the Geographical Society, and to have rendered myself more deserving of the flattering and benevolent reception which it has granted me, and of the distinction and rewards which its descriminating patriotism decrees to those who record its efforts; of that Society which, with so much zeal and success, prosecutes the 
extension of science, and which, by the encouragement it held out to those who should explore the central regions of Africa, confirmed my opinion of the importance of such travels, and determined me in the plan which I had already formed of one day attempting the discovery of Timbuctoo.

In paying this just homage to the Geographical Society, I must not omit one of its most distinguished members, M. Jomard, President of the Central Committee and Member of the Institute, who, since my arrival in France, has without intermission honoured me with his valuable advice and his personal kindness, who has not disdained to unite his name with mine, and has so largely contributed to any success with which this narrative may be honoured, by enriching it with a map founded upon my notes, and with geographical disquisitions upon a continent, the study of which has long been familiar to him, both as a traveller and as a writer. I request him to accept this public testimony of my warmest gratitude. 



\section{CONTENTS}

OF THE SECOND VOLUME.

\section{CHAPTER XIX.}

Page

Departure for Timbuctoo on the 19th of March.-Description of the banks of the river.-Slaves released from their chains.-Populous villages.-Vessels of from sixty to eighty tons burthen.-Branch of the river forming a large island. - Mode of building canoes.-Villages of Banan.-Character of the Mandingoes.-Description of Lake Debo.lslands called St. Charles, Henry, and Maria-Theresa .

\section{CHAPTER XX.}

Tongom, a village in the country of the Dirimans.-Co.-Do. -Sa, a commercial purt.-Mercantile flotillas.-The Soorgoos or Tooariks, a nomadic and predatory tribe.Baraconga._Lelel. — Garfola. - Filinsa. - Baracondié. Tircy.-Liquor made from the kondoo.-Alcodia, the Diriman capital.-Customs of the inhabitants.-Salacoila. -Cora.-Coratoo.-Separation of the river into two branches.-Arrival at Cabra, the port of TimbuctooDescription of the place. . . . . . . . . .

\section{CHAPTER XXI.}

Journey from Cabra to Timbuctoo.-First view of the city.The Kissoors.-The king grants the traveller an audience. -Condition of the slaves.-Description of the city, its buildings, extent, and commerce.-Food and dress of the people.-Bousbéhey, a city of the Zawats.-Toudeyni.Tribe of Salah.-Terror inspired by the Tooariks.-Description of that tribe.-The Jinbalas. - Particulars respecting the fate of Major Laing.-Reflexions on the means of penetrating to the centre of Africa . . . . . . 48 


\section{CHAPTER XXII.}

Departure from Timbuctoo on the 4 th of May, 1828.-Caravan of six hundred camels. - Entrance of the desert.-Suffocating heat.- The caravan falls in with the Tooariks.Manner in which the Arabs direct their course in the desert.-Aspect of Sahara, like the bed of a sea without water.-Details respecting the caravans. - The place where Major Laing was assassinated.-El-Arawan, a city in the desert: its springs, population, and trade.-Information respecting Tawât and Walet.-Caravan of four hundred camels. - Disheartening effect of the view of endless sands

\section{CHAPTER XXIII.}

Violence of the east winds.-Pillars of sand.-Scarcity of water.-Deplorable situation of the caravan.-Hills of loose sand.-Rocks of granite.-Wells of Telig.-Toudeyni, rich salt mines.-Thistle of the desert.-Vexations and persecutions of the Moors, their intolerance.-Wells of Cramès.Wells of Trases or Trarzas.-Trajacant Moors. . . . 108

\section{CHAPTER XXIV.}

Wells of Amoul-Gragin._Enormous serpents.-High sandhills called Helk.-Wells of Amoul-Taf.-Hills of variouscoloured granite.-Wells of el-Ekseif; very good water.Wells called Marabouty, el-Guedea, Mayara, and Sibicia.High and steep mountains, defiles and precipices._A severe fall._Encampment of Sidi-Aly._El-Harib._The Berbers. Tatta.-Description of the country at el-Harib, customs; the tribes who inhabit it. . . . . . . . 131

\section{CHAPTER XXV.}

Country of el-Drah-Zawât.-el-Hamid.-Buunou.-Town of Mimcina.-Camp of Berbers.-Tabelbât.-The Tawâts. -Wells of Yeneguedel, of Faratissa, of Bohayara - Customs of the Berbers. - Wells of Goud-Zenaga, of Zenatvia. 
-Town of el-Yabo. - Wells of Chanerou, of Nyela.-Arrival at Tafilet.-Town of Ghourland.-Market.-Ressaut, the residence of a Governor under the Emperor of Morocco -

\section{CHAPTER XXVI.}

Description of Tafilet and its commerce.-Flourishing state of agriculture and industry.-Miserable condition of the Jews ; their habits and customs.-Afile.-Gardens.-Tanneyara, Marca, M'Dyara, Rahaba.-Chains of granite mountains.-Small river of Guigo.-L'Eyarac, Tamaroc Kars, Ain-Zeland, L'Eksebi.-Very high mountains covered with cork-trees._L'Quin.-Guigo.-Town of Soforo.-Town of el-Fez, or Fez, the ancient capital of Morocco

CHA PTER XXVII.

Description of el-Fez.-Markets, monuments, gardens, police.-Mequinaz.-Inhospitality.-Arm of the sea called Sbo.-Arbata or Rabata or Rabat, the ancient Sallee. -Visit to the Consular Agent.-The traveller avoids the camp of the Emperor of Morocco.-Writes to the Vice Consul M. Delaporte.-Larache.-Arrives at Tangier 7 th of September, almost dying, emaciated by want, fatigue, and fever.-Generous reception of M. Delaporte.-Anxiety of the traveller.-Is introduced by night and concealed by the Consul.-M. Delaporte obtains from the naval commander of the Cadiz station a vessel to convey him to France.

\section{GEOGRAPHICAL REMARKS AND INQUIRIES}

\section{CHAPTER I.}

$\S$ I.-General retrospect of the published information on this subject prior to M. Caillie's travels. . . . . . . 227

$\$$ II.-Analysis of the itinerary map, and of the general map of the travels. . . . . . . . . . . . 253 
ARTICIE II.

Map of the traveller's route . . . . . . . . 258

First part of the journey. . . . . . . . . . . . 264

Second part of the travels. . . . . . . . . . . . 273

Observations on the course of the Dhioliba as traced from

Couroussa to Sego and Djenné. . . . . . . . . 279 Third part of the travels. . . . . . . . . 297

\section{ARTICLE III.}

Remarks on the general map of the trave!s and the elements which serve for its basis. . . . . . . . . . . 297

Observations on the situation of Timbuctoo, and particularly on its longitude. . . . . . . . . . . . . . 306

Bearings of M. Caillie's routes. . . . . . . 314

Computation of the days' journeys. . . . . . . 317

\$III. - Of the nomenclature. . . . . . . . . . . 326

$\S$ IV. - Of some results of the travels of M. Caillié. . . . $\$ 355$

$\S$ V.-Of the course of the Dhioliba above and below Timbuctoo. . . . . . . . . . . . . . 365

\section{CHAP'TER II.}

VOCABULARIES COLLECTED BY M. CAILLIÉ.

English and Mandingo vocabulary. . . . . . . . .375

Kissour vocabulary. . . . . . . . . . . . . . 392

Observations on the vocabularies. . . . . . . . . . 401

CHAPTER III.

M. Caillie's Itinerary.

CHAPTER IV.

Explanation of the plates . . . . . . . . . . . . 427

Miscellaneous notes. . .

CHAPTER V.

Documents and miscellaneous papers. . . . . . . 445

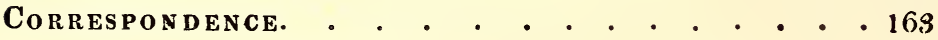


11 




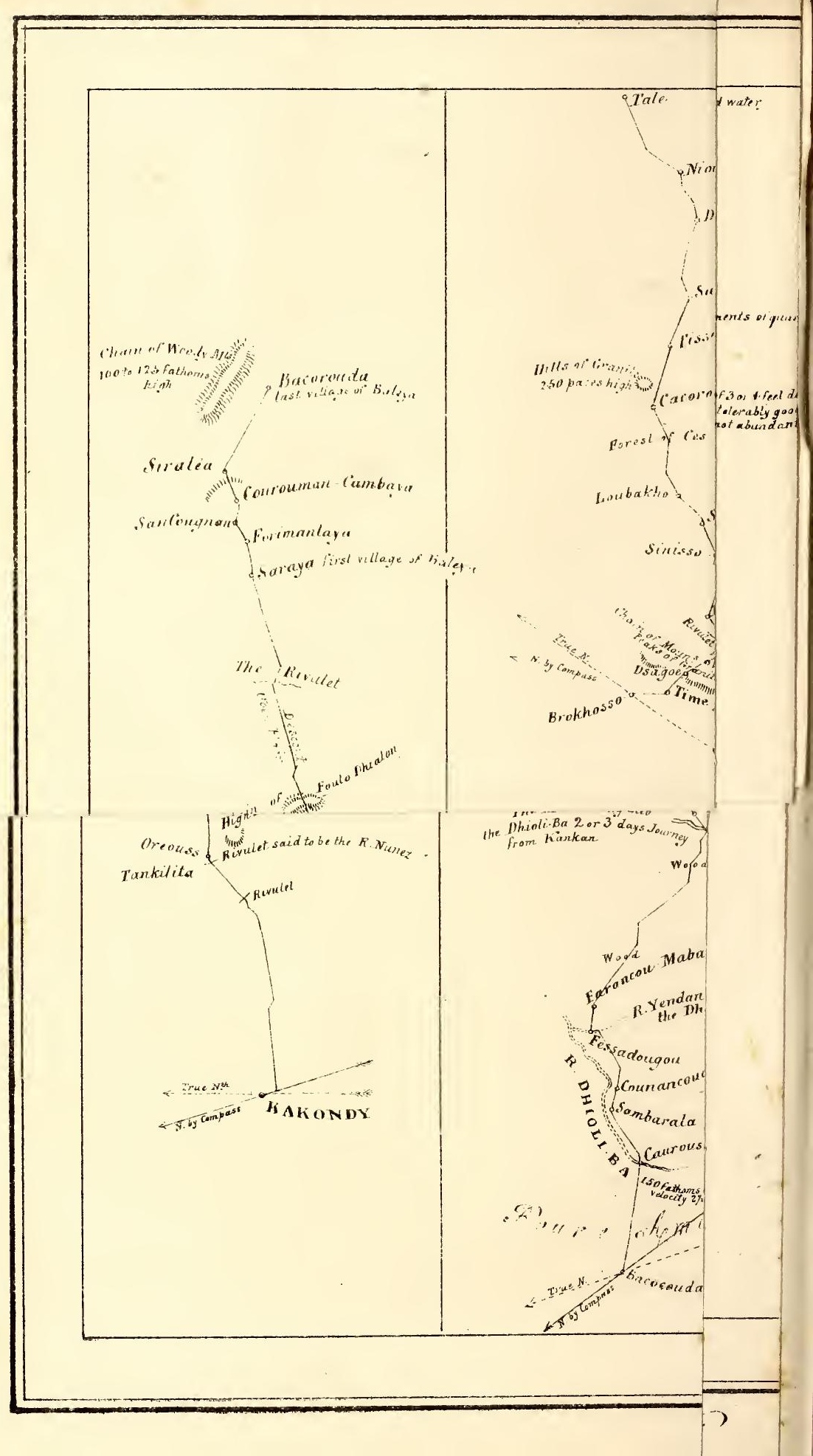




\section{TRA VELS}

\section{To \\ T I M B U C T O O, \\ $\& c ., \& c$.}

\section{CHAPTER XIX.}

Departure for Timbuctoo on the 13th of March.-Description of the banks of the river.-Slaves released from their chains. - Populous villages. - Vessels of from sixty to eighty tons burthen. - Branch of the river forming a large island.-Mode of building canoes.-Villages of Banan.-Character of the Mandingoes.-Description of Lake Debo. -lslands called St. Charles, Henry, and Maria-Theresa.

Aвоuт half past nine o'clock we left the port. We did not waste much time in adieus; my friends saw me on board, wished me a safe voyage, and departed exclaiming : Salam alécoom, Abdallah. The sherif, with whom the gift of my umbrella rendered me such a favourite, directed me to his correspondent at Timbuctoo, to whom he particularly recommended me in a letter, which he sent by the superintendent of the cargo. I had reason to be grateful for his kind foresight, to which I was indebted for the friendly 
reception I experienced on my arrival in the capital of the Western Soudan.

Though the heat was beginning to be exceedingly oppressive, 1 remained on deck, for the canoe was very full. The river makes several windings; its course is rapid; and as it is extremely shallow, we were obliged several times to unload the vessel in order to pass over the sandbanks. The negroes in the neighbourhood helped to load and unload the canoe, and to push it forward; all this, of course, occasioned considerable delay.

About two o'clock we reached the majestic Dhioliba, which flows slowly from W. N. W. At this part it is very deep, and about three times the width of the Seine at the Pont-Neuf. It takes a turn of about two miles to the south; its banks are low and very barren. The distance from Jenné to this river is, I should imagine, about ten miles. After flowing two miles to the southward, it turns to the N. N. E. About four o'clock we arrived at Cougalia, where I had previously crossed the river. Aided by the current I suppose we made about two miles an hour.

A little before sun-set we passed Kera, a pretty little village on the right bank of the river, containing about three hundred inhabitants. It is nearly seven miles from Cougalia. Here the river turns to the N. E. A little to the left there is a small island submerged during the inundation. The river is much wider here than at Cougalia, and it is quite as deep. On the plain I observed some slaves tilling the ground; they had pickaxes like those of the Bambaras. We continued our course till near midnight. As I had no compass I observed the direction of our course during the night by the polar star. In the evening we stood to the N. E., still going at the rate of about two miles an hour.

When we lay to, the negroes who had the management, of the canoe sought to pick a quarrel with me: they would not allow me to sleep on board. They told me that 
I had given them nothing, and that if I did not pay them they would put me on shore. I saw very well that their only object was to intimidate me and thereby to extort something from me. I disregarded their threats, and prepared to sleep on board in spite of them, for the cold night air and the damp were very unpleasant. I arranged my resting place as well as I could on a heap of baggage, where I was almost folded double and unable to move. I had not a wink of sleep during the whole night, and the negroes annoyed me in every possible way to induce me to leave the canoe. They even began to address insulting language to me, and threatened to put me on shore next day if I did not satisfy their demands. I suffered much from this annoyance; but the negroes gained nothing by their insolence. When the common people of these countries meet with a stranger who does not speak their language, they think they may insult him with impunity; but it is sufficient to shew firmness to make them more tractable. They gave me for supper a little rice boiled in water, which was the food of the slaves. I had not eaten any thing all day, for there was no possibility of cooking on account of the crowded state of the canoe.

At four in the morning of the 24th of March we stood to the N. E. The sailors pushed forward the canoe with a long pole: they rowed it in deep water, and sometimes towed it along shore.

At this part, the river is about half a mile broad and very deep. Its banks, though low, are adorned with a species of mimosa, which grows only to the height of a small shrub. About seven in the morning we stopped before the village of Soufara, situated on the right bank, on a height which preserves it from the inundation. Beside this village is a little stream, which runs in an eastward direction. We went ashore to purchase some maumies and pistachio-nuts for breakfast. In this place there is no regular 
market; but people go through the streets selling pistachios, and other little productions of the country. The village probably contains about two hundred and fifty inhabitants. They live in wretched huts, built of earth like those of the Bambaras, which do not approach the perfection of the habitations of Jenné. The people catch a great quantity of fish. They generally use nets made of cotton, but sometimes fish with the line. When I returned on board the canoe, the negro who was the master of the slaves and superintendent of the cargo gave me a piece of cake for my breakfast. Fortunately $\mathbf{I}$ had provided myself with some on shore, otherwise I should have made a sorry repast. The negroes again importuned me for cowries; but I persisted in my resolution to give them nothing. At half past seven we continued our course. The river now took a northerly direction. It continued wide, and its depth was about ten or twelve feet. This I ascertained by observing the long pole with which the sailors pushed the canoe. It was nearly eleven o'clock when we passed Cabia. In front of this village there are three little islands; here the river takes a turn to the N. E. and becomes narrower. About two o'clock I observed its direction was north, and at half past three, north-east. Its width and depth continued much the same; its banks were barren and low. On both sides I observed immense plains, the uniformity of which was broken only by some ronniers which rise majestically to the height of about eighty feet from the ground and bound the horizon. About five in the afternoon we perceived the village of Taco, which is situated on the left bank.

At sun-set I discerned, in the direction of the east, two little hills about six miles from the bank of the river, which in this part runs to the north. About seven in the evening we stopped before the village of Coona, which, is inhabited by Foulahs, who live in straw huts. In the port there were some canoes, all going to Timbuctoo. Here we could plainly 
perceive the two hills I have just mentioned, and a little to the north-east were three others of similar height. We passed the night in this village, which, like Taco, is situated on the left bink.

On the 25th of March I was informed that the great canoe which was to convey us to Timbuctoo was in the port and ready for our reception. It was covered with mats, and laden with rice, millet, cotton, honey, regetable butter, and other productions of the country. The canoe appeared to me very fragile; like the smaller ones its planks were joined with cords; its burthen was about sixty tons.

We were occupied all day in getting the merchandise from the small canoe, and putting it on board the large one. There was on the shore a great concourse of people, all engaged in some kind of labour; they had pitched tents to shelter themselves from the heat, which was excessive. The negroes offered us their merchandise for sale. On seeing them $I$ almost imagined myself in a market on the banks of the Senegal. The village is situated on a little eminence, and is scantily shaded by ronniers and mimosas. The heat was suffocating. I went to visit the market, which was very badly provided; for it was then the time of the Ramadan: there was a little milk, some pistachios, dry and fresh fish, maumies, and other light articles of food. The people looked at me with indifference. The young girls, who offered their merchandise for sale, had a very pleasing mode of address ; but I bought nothing, on account of the presence of the Foulahs, who are even more fanatical than the Moors, and who, if they had seen me eat, would have set me down for an infidel. My hosts at Jenné had however made me promise that I would not fast on my passage, observing that I could make up by fasting at Timbuctoo for the number of days during which I might neglect the practice of that religious duty. I sat down beneath a tree on the bank of the river, and amused myself for a short time by observing 
a group of young negroes of both sexes, who were bathing, dancing and gamboling about in the water.

A little to the north of the village the river is intersected by a sand-bank. This bank was covered by a multitude of water-fowl of various kinds, whose white plümage looked like a sheet of snow in the midst of the river. The channel for the passage of canoes is near the right bank. The surrounding country is very barren : not a single shrub is to be seen. The soil consists of immense marshes, which are inundated at the swell of the waters. The shore on either side is so extremely low that the river seems on the point of overflowing its banks. In the village $I$ met with a Moorish trader, who was returning from Timbuctoo in a common canoe, laden with salt. He told me that he had been a month on his way from Cabra to Coona. I invited him to come on board our vessel and take a little refreshment of dokhnou and water. Dokhnou, as I have before observed, consists of a mixture of the flour of millet and honey, which is afterwards mixed with water for drink. He requested me to wait until sun-set on account of the Foulahs, who, if they saw us drink, would have a bad opinion of us. He left me to take a turn in the village, but I did not see him again.

In the port, there were many fishermen's canoes. When the fishermen catch their fish, either with the net or the line, they dry it in the sun and sell it to the vessels which are continually stopping in their port : they also carry it to Jenné for sale. At two o'clock in the afternoon, I was informed that dinner was ready, and was asked whether I would partake of it; for the slaves were not required to fast, and I was ranked among them. That I might not be observed by any one, I went on board the canoe to take my dinner at my ease. It consisted of a little boiled millet-flour, without any seasoning. After this frugal repast, the slaves were freed from their chains, and I was gratified in witnessing the 
pleasure which these poor creatures experienced during their temporary release from bondage. They appeared perfectly happy. They tried to walk, but it was with difficulty that they could move a few steps, for the chains which they had worn since they left Jenné had wounded their feet.

Having nothing more to detain us in the village, we left it in the afternoon during a calm, taking a northern direction. The large canoe did not get on so well as the small one which we had left behind us, consequently we scarcely made two miles an hour.

About five o'clock we passed Taguetia, situated on the left bank. In front of this village a marigot, or branch, about twenty-five or thirty fathoms wide, runs off to the east. The village of Sangouno is on one of the banks of this branch. At its mouth are two little islands, about a quarter of a mile in circumference, on which are some fishermen's huts. The river still continues of the same width, running to the north. It is very deep, and its banks are low and barren.

At ten at night we stopped at Sankha-guibila. At this place the river takes a turn to the east, and then to the north. The inhabitants hold a little market, to which they bring milk and dried fish, which the negroes of the canoes purchase, and pay for in cowries, the only money current on the banks of the river as far as Timbuctoo. People came from all sides with earthen pots, calabashes, mats, and various other kinds of merchandise. This village probably contains about four hundred inhabitants, consisting of Foulahs, Mandingoes, and Bambaras from Jenné.

At three o'clock on the morning of the $26 \mathrm{th}$, we quitted the village of Sankha-guibila, the huts of which are all of straw, and badly constructed. We advanced slowly to the west. At sun-rise we found the river take a turn to the north. Its banks are adorned with a few dwarf shrubs.

At four in the afternoon we passed Diébé, situated on the 
right and before which there is a sand-bank. In general, all these villages resemble each other. The population varies but little. We stopped here nearly two hours to escape the north wind, which was blowing furiously, and which, in all probability, would have destroyed our frail bark. When it ceased we continued our course, and at nine o'clock we lay to at J saca, where we passed that night and the following day. During the night the wind changed to the north-east, and there was a good breeze stirring. The banks of the river are so low that the least wind prevents the canoes making way; for when the water is ever so little agitated the waves dash over their sides and sink them; an accident of frequent occurrence. The population of Isaca may amount to seven or eight hundred, all Foulahs. Their houses, which are built of bricks baked in the sun, resemble those of the Bambaras.

The inhabitants brought us fresh fish, sour milk, and butter, which we purchased. The butter was rolled up into little balls of the size of crab-apples, for which we paid six cowries each. In this village I saw a great quantity of dried fish, an article in which the inhabitants traffic very considerably. They carry it to Jenné and other neighbouring markets. The great arm of the river which, as the negroes informed me, branches off from Sego, and forms an immense island, rejoins the river a quarter of a mile from Isaca. This arm, which comes from the west, is very broad, and seems to be navigable for large boats. It has not a rapid current; indeed, the water appears to be almost stagnant. The village is situated on the right bank of the river, and is inhabited by Foulahs, similar to those of FoutaDhialon. They are the subjects of Sego-Ahmadou, the capital of which al-Lamdou Lillahi, is a day's journey eastward from Isaca. They rear flocks, which are their principal wealth, and cultivate rice in the plains, inundated by the overflow of the waters. They fish with nets made of cotton cord. 
The women manufacture a beautiful kind of pottery, which they sell at Jenné, and to the canoes going to 'Timbuctoo. The village is situated on a little eminence; it is a great market for provisions.

Before I proceed further I will give a description of the canoes which are employed in the passage from Jenné to Timbuctoo, and which keep up a continually active trade along the whole extent of the river. Little flotillas of sixty or eighty boats are frequently seen all richly laden with various kinds of produce.

A vessel of sixty, or eighty tons burthen, is about ninety or one hundred feet long, twelve or fourteen broad at midships, and draws six or seven feet depth of water. These canoes, whether large or small, are generally fragile, and it is astonishing how they bear the heavy cargoes with which they are laden, and which consist of rice, millet, butter, honey, onions, pistachios, colat-nuts, stuffs, and various kinds of preserved articles. In addition to their cargo they frequently have on board forty or fifty slaves, half of whom remain on deck.

The crew consists of sixteen or eighteen sailors, two steersmen, and a superior, who acts as captain. The manner in which these vessels are built shews their want of solidity. Large planks, five feet long by eight inches broad, and about one inch thick, * are adjusted and fixed together by ropes made from the hemp of the country and the leaves of the ronnier. These ropes possess the property of lasting a long time in water, an advantage of great importance in this country, where the inhabitants do not avail themselves of the use of iron.

The workmen first of all join the planks together; but they

* These planks are sawed; of this, at least, I think I am certain. The natives are indebted to the Moors for the knowledge of the saw. Wood is so scarce in this country that it is necessary to make a tree produce as many planks as possible. 
do not unite closely, and large interstices are left in this first joining. The seams are then caulked over with bruised straw, reduced to a sort of oakum, and mixed with a soft kind of clay, found in the morasses and on the banks of the river. The interstices thus filled up, the seams are closely covered with fresh straw, and the whole is strongly fastened by a second joining; this renders the canoe sufficiently solid for the purpose of navigating the river. At the bottom, wooden bars are laid at certain distances to consolidate the whole mass ; and similar bars are placed higher up, for supporting the deck. The hull being finished, it is covered over with small pieces of flexible wood, bent in a convex form, across which, other pieces of smaller size are fixed. This forms the deck, which is raised three feet and a half above the sides, and covered over with mats, made in the country from the leaves of the ronnier. The lightest merchandise is placed on the deck, or orlop, and is firmly lashed to the gunwales of the vessel, forming a sort of barrier, not very high, but sufficiently so to prevent the slaves, who sleep on deck, from rolling into the water. The vessel is loaded to the height of two feet and a half or three feet above the deck, even on the prow.

As they are unacquainted with the use of pumps, they leave in the middle of the canoe an open space, where two men are constantly stationed, and whose business it is to bale out the water which makes its way through the seams of the vessel. In spite of the quickness with which they work, the water on board is never less than half a foot deep. These men keep watch as in our European ships, and they are relieved every six hours. They use large calabashes to bale the vessel. I observed that this part of the canoe is always covered with moss of a fine green colour. This is also the place where the women kindle fires to cook the victuals of the crew; for which purpose they provide themselves with portable earthenware stoves. These stoves are in the form of chaffing-dishes, round and open, and are composed of 
glazed earthenware. 'They are manufactured at Jenné, or in its environs, and are nearly four feet in circumference. They are furnished with three little supports, forming a tripod, on which the pot, used for boiling the rice, rests. These portable stoves obviate all danger that might be apprehended from the use of fire on board the vessels. Before the cargo is put on board, the hold is lined with thick pieces of wood, to prevent the goods being damaged by damp.

These vessels being unprovided with sails, cannot make way except in very calm weather; they are besides so frail, that the slightest wind agitating the river (the banks of which are very low) produces waves, which, by dashing against the sides of the canoes, would either damage or swamp them. This danger often causes delay, and renders the navigation tedious and perilous. When the banks are entirely free from bushes, the sailors row or tow the vessel along, and when they can reach the bottom of the river with poles, they push it. In this manner the greater part of the passage is effected, and it was by means of these poles, which are about twelve or fifteen feet long, that I was enabled to judge of the depth of the river. It is very difficult to find wood of such a length in this country, and it is necessary to fix two pieces together lengthwise to form the poles. It sometimes happens that the banks are covered with bushes, and that the river is so deep that these poles cannot reach the bottom; in such cases the sailors move the vessel forward by paddles three feet long; and a place for the rowers is left open, quite at the fore part of the vessel, occupying only twelve or fourteen feet. They sometimes stand up close against the side of the vessel, and at other times sit upon the merchandise, having scarcely room to turn themselves round in consequence of the crowded state of the canoe. These men are naked; they row very fast, and keep time.

The master stands at the stern and steers the vessel, 
not without difficulty, by a long pole instead of a rudder. He experiences a good deal of trouble in managing the unwieldy machine, so that it is often found necessary for two others to assist him. A rudder like that attached to the boats which descend the Seine, would be extremely serviceable, but at present the people are ignorant of the use of such a thing. Each of these vessels has a captain, who maintains great authority over his crew, and I never witnessed any abuse of this authority, as is sometimes the case with us, especially in the merchant service. All the negro sailors who navigate the river are slaves; there are also some captains of this class, whose employers give them half of what they earn. Free men think themselves degraded by accepting such employment.

On the 28th, at four o'clock in the morning, the wind fell and we continued our course towards the north. The breadth of the river did not vary, and its banks continued low and naked. About seven o'clock in the morning the N. E. wind blew stronger than on the preceding day, and we were obliged to anchor before a large plain of white quicksand, which, when inundated by the rising of the waters, forms a great bank; the channel is on the left side of the river. The wind, blowing up the sand in great quantities, added to the inconvenience we were suffering from the heat.

To lighten the canoe all the slaves were set on shore, and the rice-grinders were sent to continue their work on the plain. At sunset the wind fell a little, and the oars might have been used during the whole of the night, but the negroes, to whom time is of no value, and who are never in a hurry to reach their destination, thought proper to wait till morning.

The slaves, male and female, all Bambaras, began to leap, dance, and amuse themselves in various ways. Their gaiety, however, proved the cause of some trouble to us, for 
the Foulahs, observing them, came on board at night-fall in a party of about thirty, armed with bows and pikes. They severely censured the impropriety of allowing the slaves to dance during the Ramadan, observing that it was like making a scoff of religion, and that, as a punishment for such misconduct, a fine of five thousand cowries (a sum equal to twenty-five francs) must be paid. The master, to whose charge the slaves had been committed, earnestly defended the cause of his employer. A spirited altercation arose between the parties, who were seated in a circle upon the sand. The Foulahs for some time shewed no disposition to forego their demands, but at length they were taught reason, and the dispute ended at the expense of the poor slaves, who, as a punishment for dancing during this sacred season, were each condemned to receive five lashes on the back. The sentence, however, was not executed with much severity, and it did not restrain the slaves from resuming their dance as soon as the fanatical Foulahs departed.

From motives of prudence, I had for some time kept myself apart from this scene, but I felt curious to know, belore the departure of these rigid defenders of Islamism, what was the subject of dispute. I therefore approached the spot where they were and sat down on the sand beside them. They were astonished at seeing me, for I had hitherto escaped their observation, owing to the interest they took in discussing the subject of the five thousand cowries, which they conceived they had a right to exact. They told the master that I must certainly be the chief of the canoe and the proprietor of the cargo; that I must doubtless have money; and that I must make them a handsome present.

The master answered them that I was a poor Arab, whom the christians had carried off from his country when a boy, and that I was proceeding to Mecca, to seek my relatives. 
This explanation seemed to satisfy them, for they asked no more questions about me.

The proprietor of the canoe had put a Mandingo negro on board, to take care of the cargo. This person was also directed to attend to me; a duty which he performed very negligently, for, after leaving Jenné, he gave me nothing but rice boiled in water, the food of the slaves. He was more strict than the Moors, and fasted on the voyage, not partaking of any thing until a repast was served to us at half past six in the evening. This was the best meal I had throughout the day, for he added a little dry fish and vegetable butter to the dish. However, he made me eat at other times with the slaves. I complained of this treatment, but the only reply given to my repeated remonstrances was, that he did not choose to have the trouble of lighting a fire for only one person, and that I must be content with what he gave me. Not being able to do better, I patiently bore my misfortune, and considered myself lucky when I procured a little sour milk to relish my dinner.

On the 29th of March, about three o'clock in the morning, we again put off. During the night time, the polar star served me for a compass, and the position of the stars enabled me to guess the hour. About nine o'clock a fresh breeze having sprung up, we were obliged to wait till midday, when we began to move on. At two o'clock we again stopped. The excessive heat brought upon me an attack of fever, which, fortunately, was not followed by any bad consequences. At five o'clock in the evening, the wind dropped, and we were enabled to continue our voyage. At sun-set, we passed a village on the left bank, close to which an arm of the river branches off to the west. At eight in the evening, we found ourselves before Wanza, having constantly advanced in a northern direction. We lay to about one o'clock in the morning, at a point where there was no 
village. Here the river might be three quarters of a mile broad, and from eight to nine feet deep; the banks were uniformly low and bare.

On the 3oth of March, at six in the morning, we put off, still in the same direction. About nine o'clock, a violent north-east wind arose, and obliged us to halt before the village of Sansan. Here the river is of considerable breadth, but the banks being ornamented with mimosas, presented a pleasing prospect after the long absence of all vegetation. About five in the evening, the wind falling a little, we advanced to the north-east. The country on either side of the river was covered with numerous herds of oxen, whose lowing was heard at a great distance; they belonged to the Foulahs, residing in a village at some distance from the shore, and whose only property is their cattle. At six in the evening, we passed over a sand-bank, extending across the river, which is here a full mile in breadth. The canoe ran aground several times, and the men were obliged to jump into the water in order to get it afloat, for which about four feet and a half water was requisite. By great efforts we gained the channel, which runs near the right bank. Here I saw thousands of trumpet-birds, which came down in flocks upon the sand banks, and by their shrill cries seemed to sound a charge upon the fish, destined by nature for their prey. There were also great numbers of ducks, water-fowl, puffets, pelicans, and egrets, and multitudes of the other varieties of water birds, which inhabit these marshes, and brood undisturbed by the people of the surrounding countries. Powder is a very scarce article here, and lead is unknown; pikes, therefore, form the only arms of the inhabitants.

We continued our course till midnight; when, our wearied rowers requiring rest, we moored the vessel to two stakes fixed in the shore, and went to sleep.

On the thirty-first of March, at six in the morning, we 
started in a northern direction. At seven we passed the village of Corocoila, situated on the right bank. This place contained from five to six hundred inhabitants, chiefly Foulahs, and also some who came originally from Jenné. In all the villages on the banks of the river the same language is spoken as at Timbuctoo and Jenné ; it is called the Kissour. The Foulah language also is spoken in those places. The banks of the river were still covered with numerous herds of oxen.

At ten o'clock, we lay to about two miles to the north of Cobi. Between this small village and Corocoilla is a pretty little island, about two miles in circumference, covered with the finest vegetation; I was astonished to find it uninhabited. In the evening we made three miles towards the north, for the purpose of reaching Cona, the first village in the country of Banan, which the negroes call Banan-dougou (land of Banan). Cona contains about eight hundred inhabitants, all negroes. There are in the country some Mandingoes and Foulahs, who are engaged in trade. It is situated on the right bank of the river, and its environs are marshy.

The people on board our vessel purchased tamarinds, earthen pots, and untanned ox-hides used for packing. The inhabitants brought us milk, giraumons, and other articles.

In this place I met two Moors from Adrar, owners of a very large canoe of eighty tons burden at least. They were going to Timbuctoo to dispose of the merchandise they had bought at Jenné. A small vessel of seven or eight tons, was employed to carry themselves and provisions for their use and it followed the large canoe at various distances; for the latter, encumbered with merchandise, advanced but slowly.

After introducing themselves, they invited me to partake of their boiled rice and some milk, while supper was preparing. About seven in the evening they proceeded on their passage, but we stayed until the next day. Several of our 
men went to the village to make small purchases for a venture. Banan is independent of Ségo-Ahmadou: it is situated upon the right bank of the river, and extends very far to the east. The inhabitants are all Mahometans, and the slaves, who are very numerous, are employed in tilling the ground. The people build canoes, and make voyages to Jenné and Timbuctoo. They are very rich in herds of oxen, sheep and goats, and rear great quantities of poultry. They are very industrious, and manufacture cotton stuffs, which they sell to the people of the neighbouring towns and villages. The cotton tree, which they cultivate, flourishes exceedingly in this place. They also make cloth from the wool of sheep, for the purpose of traffic.

I saw the inhabitants, who never go out unless armed with pikes, and bows and arrows. They have woolly hair and a very black complexion, and are in other respects like the Mandingoes, to which race indeed they belong, though they speak another language.

About ten at night, we left the village of Cona, with a fine moon-light that would have favoured our progress, but the negroes thought proper to lie to at eleven o'clock. $\Lambda \mathrm{s}$ soon as the ressels are anchored they beiake themselves to sleep, without leaving any one to keep watch, for they are not accustomed to such duty when at anchor.

On the 1st of April, at six in the morning, we made ready to start : a breeze was blowing, which however, about midnight so encreased in violence, that we were compelled to stop. Had we attempted to proceed, the canoe would infallibly have been destroyed; for during this gale it made more water than usual.

The frequent halts which we were obliged to make were very annoying to me; for I was obliged to remain on board exposed to the heat of the sun. How pleased should I have been had the adjacent country been like the smiling shores

VOL. II. 
of the Senegal! But here the immense monotonous plains on all sides fatigue the eye of the traveller.

The course of the river, though winding in some parts, is still northward. On the morning of the 1st of April, I observed a large hill, about two hundred and fifty feet high, distant three or four miles from the left bank of the river. It was without vegetation, and appeared to be composed of red sand.

We daily expected the owner of the canoe, who, on departing from Jenné, promised to join us in two days. He had assured me, that even in his absence I should be well treated on board. The case, however, was quite the reverse, so I looked for him with the utmost impatience, trusting that his presence would better my condition.

After my departure from Jenné, I had the misery of being the only white man among the negroes, and with their language I was unacquainted. This circumstance, joined to my being a stranger, and almost destitute, emboldened them to insult me in the grossest manner. I was absolutely ranked and treated as a slave.

During the day the heat was excessive, and I had great trouble to find a place where I could be shaded from the burning sun, which was almost insupportable, even in a state of inaction. In the night I slept on deck, for there was no room for me below. I was exposed to the dew and all the inclemency of the night; but I took the precaution of wrapping myself in a sheep-skin. However, this did not prevent me from being seized, on the 31st March, with a violent fit of illness. I experienced severe numbness, followed by great weakness, and my stomach rejected food.

During my illness I was permitted to go into the cabin; but the place assigned me there was very inconvenient. I was with a Mandingo and his female slave; and they allowed me so little room that I could not lie straight; my head 
touched my knees. I had been particularly recommended to the care of this negro by the sherif Oulad-Marmou; but he paid no regard to the directions he had received, and showed as little pity for me as the rest of the crew. I ought, however, to exempt from this censure a young Foulah from Massina, to whom the sherif had also recommended me. He was the only one who had behaved to me with any kindness. He went on shore whenever I asked him, bought me milk, and rendered me all the service he could. He even endeavoured to console me when I expressed dissatisfaction at the inattention with which 1 was treated by the rest. He often reprimanded the slaves, who, following the example of their superiors, behaved with the grossest insolence towards me. In short, I should have been much worse off had it not been for the attention of this kind-hearted young man.

In the course of my travels I have often had intercourse with the Mandingoes, and, with the single exception of those of Cambaya, in the Fouta, I have always found them arrogant when possessed of any little authority, while they are fawning, mean, and servile, to their superiors. 1 have seen them, in the passage from Tinné to Jenné, insult the poor Bambaras while selling their merchandise, speaking harshly to them, and even abusing them in their own language; but whenever the Bambaras showed a disposition to resent this treatment, the Mandingoes became all at once silent and humble. The women have the same faults, in addition to which they have insufferably harsh voices.

On the 1st of April, the wind continued blowing till four in the evening, when it fell a little. We rowed in a northern direction. Near half past six in the evening we halted at Toï. The river still continued the same; the banks being low and bare, and in many places not a single shrub can be seen. At nine o'clock, we started, and all night advanced towards the north. The river makes a few small windings to the east. 
On the 2nd of April the weather continued calm. Towards eight o'clock in the morning we passed some large islands, situated not far from the mouth of the lake Débo. The river is here divided by several islands, which separate it into different narrow branches of great depth. Two of these islands are larger than the rest, and might be habitable, for, when the river overflows, they are only partially inundated. On one of these islands, there are the huts of fishermen, and of shepherds, whose numerous flocks find rich pasture on the marshes. These marshes are covered by aquatic birds of every kind. There is an infinite number of other small islands covered with rank grass, and inundated at all seasons. When this immense river overflows all the herbage is under water, and then the lake appears much more extensive; its banks are no longer perceptible, and it might be mistaken for an inland sea.

After a slow navigation, during which we made repeated halts, we reached the mouth of the great lake about three in the afternoon. About six miles S. W. of this entrance, there is a rock in the form of a truncated sugarloaf; it is situated in an inundated marsh which is covered with green herbage. This enormous rock, which is quite bare, forms a singular contrast with the freshness of the surrounding vegetation. As it has, though a very striking land-mark, received no name from the natives, I thought proper to give it one, and have named the whole spot St. Charles's Island. In the lake, and about nine or ten miles to the N.E. is a small island on which 1 observed some trees almost destitute of leaves. It is capable of being inhabited, and affords facilities for the formation of a good port. I have named it Henry Island, in honour of his Royal Highness the Duke of Bourdeaux. A third island, also formed of rock, is situated between these two, a little to the eastward of the line which would intersect them, and to it I have given the name of Maria-Theresa, in honour of 
her Royal Highness the Dauphiness. Two of these islands appear to command the mouth of the lake. Were a fort built on one of the three it would command the environs, and the navigation would be under the control of the possessor.

To the N.N. E. of the island of Maria-Theresa we observed a hill about fifty or sixty fathoms high. It is composed of red earth, and of large porous rocks of the same colour. Some fishermen have established themselves on the declivity of this hill, which is extremely arid.

Land is seen on every side of the lake except on the west, where it spreads out like an inland sea. On coasting along its northern side, and steering nearly W.N.W. to the distance of fifteen miles, we leave on the left a tongue of very flat land, which extends several miles southward. It seems to close the passage of the lake, and to form a kind of strait. Beyond this barrier the lake is prolonged, as I have said, towards the west, until it is lost in the horizon.

The barrier I have just mentioned divides lake Debo into two lakes, the upper and the lower. 'That through which the boats passed, and in which the three islands I have mentioned are situated, is very large. It extends in an easterly direction, and is surrounded by extensive marshes. Land is visible on every side.

When we had advanced as far as the middle of the first division, three of the large boats fired some muskets, to salute this majestic lake, and the crew of each boat shouted with all their might Salam! Salam! repeating the cry several times. We stood off from the eastern bank and navigated with great caution: the lake was calm and the water clear. The current was not perceptible on its surface, the depth of the part which we navigated was twelve or thirteen feet. The canoes were merely rowed, and advanced very slowly. I could not recover from my surprise 
at seeing so great a mass of water in the heart of the country. There was something very majestic in the sight.

About five in the evening we arrived off Gabibi, a small fishing village on the right bank of the lake. The huts of this village are made of straw and of a round form. Since we entered the lake we had stood to the N.E. We passed close to the island of Maria-Theresa, on which I observed some fine granite of a bright chesnut colour. We took our departure from Gabibi, and at sun-set I saw, for the first time, since I left the coast, that luminary sink into a sort of ocean.

We proceeded along the shore, at some distance from it, in the direction of W.N.W. The boatmen sang while they pushed along the canoe with their poles. We observed large blocks of granite on the shore. We brought to about eleven at night off Didhiover, a large village inhabited by Foulahs, who have only straw huts like those of the pastoral Foulahs. Some negroes went to the village to buy giraumons. We could not procure a single drop of milk. 
Tongom, a village in the country of the Dirimans.-Co.-Do.-Sa, a commercial port.-Mercantile flotillas.-The Soorgoos or Tooariks, a nomadic and predatory tribe-_Baraconga.-Lelel.-Garfola.-Filinsa. -Baracondié.-Tircy.-Liquor made from the kondoo.-Alcodia, the Diriman capital. - Customs of the inhabitants.-Salacoila.-Cora.Coratoo.-Separation of the river into two branches.-Arrival at Cabra, the port of Timbuctoo.-Description of the place.

ON the 3rd of April we took our departure from the village of Didhiover, which is situated near the northern entrance of the lake. The river on issuing from the lake may be about six miles broad. At sun-rise we stood towards the north. In the course of the morning we passed the village of Tongom, which belongs to the country of the Dirimans. It contains about four or five hundred inhabitants.

About one in the afternoon, we lay to at a spot where we observed bushes and cut some for fire-wood. At this spot the river is only about three quarters of a mile broad. I went ashore with the slaves. The land, which is subject to inundations, is not destitute of vegetation. I saw naucleas and mimosas twelve feet high. In the course of the voyage, the master of the canoe asked me to lend him five thousand cowries, until the Moor, who was the owner, and who was daily expected, should arrive. The negro had already cheated me more than once, and as I was apprehensive that $I$ should never be repaid, which would have infallibly been the case, I refused to lend him such a sum. He made several individuals apply to me for him, but I would not comply. Finding that I was determined not to lend him 
the cowries, he threw out threats against me, and went so far as to pull me by the legs to make me leave the boat. He collected what articles belonged to me and threw them on deck, accompanying the action with many violent and rude expressions. He intimated that he would drive me among the slaves, and thus insulted me in a thousand different ways.

When I went on shore he objected to my going in the small boat. I knew not to whom I could complain of all these vexations, for there was no person on board who could protect me. At last the young Foulah obtained his consent to my going in the little canoe, to be put on shore along with some slaves. On landing, I seated myself under the shade of a mimosa, and, reflecting sorrowfully on the disagreeable situation in which I should be placed during the voyage if 1 did not lend him the cowries, I resolved to make that sacrinice. He came on shore to me, and assailed me with fresh reproaches, insisting at the same time that I certainly ought to place confidence in him, and assuring me that he would repay the debt on the arrival of his master. Though my resources were greatly diminished, and I felt that the strictest economy was indispensible, I promised for the sake of peace to lend him a thousand cowries. From that moment our quarrel terminated. His example was however followed by one of his comrades. These two negroes completely abused the advantage which circumcumstances had given them over me; and when we arrived at Timbuctoo I found it impossible to procure repayment.

About three o'clock in the afternoon, while we were proceeding on our royage, the canoe, which had put off from the shore with the slaves to bring them on board, sunk in consequence of being leaky and overloaded. The poor women, embarrassed by the weight of the pagnes about their loins, were in the greatest danger: but prompt assistance was given and every one was got on board without any 
further accident. It is usual to anchor the boats close to the banks of the river, but when the canoe filled we were under way.

The river here makes an elbow towards the east of about six miles; it then stretches towards the north. It is every where broad and deep, but the banks are low and bare.

About seven in the evening we anchored opposite Mujo, a village of the Diriman country, containing from three hundred and fifty to four hundred inhabitants. The huts are of straw and in the sugar-loaf form. In the evening $I$ was informed of the arrival of Sidi-Mbark,* the owner of our vessel. I immediately went to him and complained of the bad conduct of his people to me, but he paid little attention to my representations : he was along with a Moorish friend on board a small boat of six tons burthen. He had determined to get under way, immediately in order to reach Timbuctoo before us. I expressed a wish to go with him in his boat which moved rapidly, but he alleged that it was already too heavily laden, and that besides it was so small that there was not sleeping room for me. He once more consigned me to the care of the Mandingo, ordering him to supply me with provisions during the remainder of the voyage, and to treat me better than he had hitherto done. Sidi-Mbark afterwards tried to console me, advising me to have patience, and assuring me that we were not far from Cabra, which was the place of our destination.

The Moors of Adrar, whom I had seen in the country of Banan, stopped with us at the same spot. They sent SidiMbark a plentiful supper, consisting of rice, and dried meat, seasoned with giraumons and the small onions of the country. He invited me to partake of the meal; and I accepted his invitation with pleasure, for it was late and I had not yet supped. The Moors shew great address in eating

* An abbreviation of Moubark. 
with the fingers; for my part, however, though I had long been accustomed to take my food by handfuls, I was still far from being as expert as they: I sometimes let part of the mess fall on the ground which gave them great offence, and made them vent their anger in maledictions on the Christians, who, they observed, had not even taught me how to eat decently. This was the first comfortable meal I had made since my departure from Jenné. Sidi-Mbark gave his men colat-nuts to purchase provisions. I returned on board our boat, where I soon learned how little regard was paid to the directions of the master when he was absent.

At sun-rise we stood towards the north, at the rate of two miles an hour, leaving Mbark asleep in his boat; he soon got up with us however, for he had six good rowers: he came alongside of our boat and put on board some merchandise, which had embarrassed him on account of the room it occupied. He then gave his final orders and left us, expressing his hope that every man would do his duty. The river takes a turn to the west, the banks continue low, but at this spot, the right bank was not entirely destitute of wood. At ten o'clock we came to a spot were it made an elbow towards the N. E. About half past ten we passed Co, a large village, in the environs of which we observed some tamarind-trees and ronniers : the left bank is formed by sand hills. There is a little island in the midst of the river opposite to Co; it is inhabited by five or six hundred Foulahs who have numerous flocks. At noon we found the course of the river turning towards the N. E. and we proceeded with it in that direction until half-past four, when it elbowed round to the north. At this hour we passed in front of Do. The river then stretched westward. It is still broad and deep enough for the boatmen to use their paddles in navigating. At half-past six we halted at Sa, a large village surrounded with a wall and shaded by some tamarind-trees, (tamarindus indicus). This was the only village with a wall 
which I had seen on the banks of the river since we left Isaca. Here we joined from thirty to forty large boats, all bound for Timbuctoo. Many of these vessels were of about eighty tons burthen. Sa is a rendezvous for the vessels which navigate in this direction. It is their practice to assemble at this port and to proceed on the voyage together, to guard against the depredations of a tribe in the neighbourhood of this town, who often board their boats and commit acts of violence and robbery. They are called by the natives Soorgoos, and by the Moors Tooariks. There were in the port of Sa from four to five hundred persons, seamen and inhabitants, who gazed at the flotilla. The port was covered with bales of merchandise, ready to be shipped on board the canoes. The commercial activity appeared astonishing. There was something in the appearance of the flotilla far more interesting than I could have expected to find in the interior of Africa. The bustle on every side almost made me fancy myself in a trading port of Europe. The largest vessels belong to Moors, who carry on the principal trade of the country: they form themselves into companies, and employ their canoes in conveying merchandise to Timbuctoo, where they are paid their freight in salt or cowries.

On the 5th of April, at sun-rise, we got under way and steered a northerly course until eleven o'clock, when we came to a bend in the river, which then flowed towards the N. E. On every side we heard the joyous cries of the sailors, who also fired muskets, still more strongly to express their gladness. We passed the village of Baraconga, which is situated on the left bank. About one o'clock we anchored before Tantala, a pretty village, where we bought some dry fish, milk, and fine mats made of ronnier leaves. They are of a long shape and yellow colour; they are used for sleeping on, and for making sacks.

We continued our course to the N. E. until sun-set, when we passed a large branch of the river, which runs 
westerly. About seven o'clock we brought to at Cooma, where we passed the night. The river and its banks still presented the same uniformity of aspect.

On the 6th of April, at five in the morning, we got under way, and stood towards the east. The course of the river was in that direction, but with a number of small sinuosities on the northern and southern sides. About three in the afternoon we passed Lelel, a large village, containing from five to six hundred inhabitants, and situated on the left bank. A little before it reaches this village the river elbows round to the north for a mile and a half, and then turns back to the east. At half past four in the evening we passed Garfola, a village without a wall, and very much resembling the former. I observed around it multitudes of Barbary ducks and other aquatic birds. The banks in the neighbourhood of this village are somewhat elevated. Some baobabs, bombaces, tamarinds, somps, mimosas, and naucleas, adorn the environs. The river may be here about half a mile broad. About seven o'clock we anchored at Doboo, where we passed the night.

On the 7 th of April we waited to give time to the heavy boats, which we had left astern, to come up, and, about eight in the morning, stood towards the N. E. with a gentle breeze, favourable for that course. However, as it soon began to blow fresh, we anchored, about nine o'clock, at Filinsa, a village containing five hundred inhabitants. A great number of canoes were under repair in the port. I saw the carpenters at work: the only tool they used was a small hatchet, in the form of an adze, with which they shaped out, awkwardly enough, little pieces of plank, the greater part of which appeared to be in a state of decay. They were indeed fragments of old canoes which were thus used for repairs. When there was a hole in the side of a canoe, these carpenters clapped a bit of plank upon it, and fastened it, or, as it were, stitched it on with rope, made of the bark of trees. 
These patches are always very ill fitted, but the apertures which are left are stopped up with a mixture of bruised straw and clay. This compound is covered with a layer of fresh straw, which is fixed by a second stitching with bark-rope. I am astonished that boats thus constructed do not sink as soon as they are afloat. A man is kept constantly employed in baling them, to prevent their filling with the water which penetrates through the seams. These canoes belonged to fishermen. Young girls, half naked, came on board to us with milk and fresh butter.

The N.E. wind continued to blow till three o'clock, and it was five in the morning before we began to prepare for prosecuting our voyage. We had scarcely gone a mile when we observed that two large boats had fallen astern, and we thought it right to wait for them. We were then off Baracondié, a village opposite to which there is a large island, which is inundated when the water is high. All the villages from lake Debo belong to the Diriman country, which extends to a great distance easterly. A number of pastoral Foulahs also inhabit the banks of the river, and remove with their flocks when the inundations commence.

On the 8th of April, at five in the morning, we left Baracondié and directed our course westerly. About eleven we brought to off the village of Tircy. The N. E. wind, which blew a gale, obliged us to anchor. Here the river takes a turn towards the north. The village of Tircy con.tains about six hundred inhabitants; it consists of straw huts, of the same form as those of the pastoral Foulahs who inhabit the banks of the Senegal.

In the surrounding marshes I observed a number of negroes gathering a large herb, which grows only in marshy grounds. This plant is called kondoo: they dry it in the sun, and then pass it rapidly over a flame to burn off the leaves, as the stalks only are preserved. Of these they make large bundles, which they carry home on their heads. I 
also saw several asses loaded with these bundles. I asked my comrades what was done with this plant: they told me, that after it is well washed and dried by the women, it is reduced to a fine powder, which is put into a large earthen vase, having the bottom perforated with small holes. Upon the powder warm water is poured, and, in filtering, the water becomes impregnated with the essence of the plant, which is of a saccharine nature. The liquor thus obtained is much esteemed by the natives, who relish it greatly; but it has the effect of a purgative on persons not accustomed to drink it. It always retains a slightly smoky flavour, which renders it disagreeable to strangers. The Mahomedan natives indulge in this beverage without scruple: the Moors also drink it, but they always mix with it a little sour milk.

The stalk of the kondoo is as thick as a reed; it is a creeping plant, about eight or ten feet long; the leaves, which are narrow, are six or eight inches long; their edges are indented or serrated. The banks of the Dhioliba are covered with this plant. The Dirimans and some Foulahs who inhabit Tircy came to sell us this liquor, sour milk, fresh butter, dry fish, and mats. About a glassful of milk was sold for five cowries. I suppose that provisions were scarce in this village, for the dealers hawked their goods on the shore, and, in general, would take nothing but millet in payment. It is true, that among the number, there were many pastoral Foulahs who pay no attention to agriculture, and whose only resource consists in their cattle. Never travelling, and not being near any markets, cowries are of no use to them; but millet is always a ready and acceptable food. A bowl full of millet purchases twice the quantity of milk which the same bowl will hold. This is the fixed rate of dealing in the country. Young girls of twelve or fourteen years lined the bank of the river, offering to sell us their merchandise: they were nearly naked, having only a pagne round their loins. 
Soon after our arrival at the village of Tircy, we learned that some of the large boats had run aground, and that one of them had been completely swamped. This unforeseen accident occasioned considerable delay in the progress of the flotilla, which was obliged to stop in order to give assistance to the wrecked boat. The crews of the canoes hastened to help them; the greater part of the merchandise was floating about in the river, and, notwithstanding the activity which every individual displayed, only a very small part of the cargo was saved. This was a considerable loss to the owners; for, though the trade is very brisk, the merchants know nothing of the means of protecting themselves from risks by insurances. Notwithstanding this unfortunate occurrence, the Moor, whose neglect had caused it, did not appear in the least concerned.

The 9th and 10th of April were employed in dragging some bags of rice and millet out of the water; the negroes plunged in and one was drowned. All the negroes of the flotilla came to the aid of the wrecked canoe; they generally have an interest in rendering this kind of service, for they receive, by way of reward, a portion of the merchandise they save, except the manufactured stuffs, the value of which they are paid in millet and rice.

I saw at Tircy the two Moors of Adrar whom I had met at Banan; they greeted me cordially, and invited me many times to sup with them. As I knew these people think much of presents, I gave them a part of my dokhnou, a little baked bread, and a sheet of paper; these things they received with gratitude. One of them asked me whether I wanted some cowries to purchase milk with: as I had still from five to six thousand left, I thanked them, but declined their obliging offer.

The women of the Dirimans, like all who live on the banks of the river from Jenné to Timbuctoo, have their hair ornamented with small glass beads; they also wear glass, and 
sometimes metal rings in their noses. My fellow travellers told me that these people are robbers, and that they often practise great cruelties; this I was ready enough to believe, for, during the two days I staid among them, I observed much quarrelling and fighting. Their dress is the same as that of the people of Jenné ; like them, they have woolly black hair. They have handsome countenances, aquiline noses, thin lips, and large eyes; they are armed with two or three pikes and a dagger, which they promptly make use of on the least provocation. After being engaged in a quarrel, they fall devoutly to their prayers, for they are Musulmans, and they often rise from their religious duties merely to begin fresh contentions. They use the bow and arrow against their enemies; but some were armed with muskets, and some with sabres; these weapons had been introduced by Europeans. I saw a man walking on the bank of the river with a calabash full of saltpetre, which he offered for sale : I was desirous of knowing in what way it had been procured; the Moors informed me that saltpetre was manufactured in the country, and that it was used for making gunpowder.

The village of Alcodia, the residence of the chief of the Dirimans, is situated to the east of Tircy, from which it is a day and a half's journey distant. The crew, having saved all the merchandise they could, prepared to start the next day.

On the 11th of April, at six in the morning, we left the village of Tircy; the course of the river is northward. At seven o'clock we passed Talbocoila; about nine we halted to take in our stock of fire-wood. The wind blew gently from N.E. Two hours after we had re-embarked, we observed that the river, which had hitherto always continued of an equal width, became very narrow and deep; its banks were still low and bare. In many places we saw on the right bank quicksands, of a bright yellow colour; I perceived numerous herds of cattle grazing in the surrounding marshes. 
From five o'clock in the evening till seven, when we halted, the river continued its course to the north. We saw a good many hippopotami, who kept at some distance; I could see nothing of them but their heads : the negroes assured me that they often saw them, and that if they passed near the canoes they would shatter them, as it were, with a touch. The river at this part is a little wider, we crossed it to the other side during the night.

I gave the captain of the canoe (who since I had lent him some cowries had become more civil) a bit of coloured cloth, to make him a cap, on condition that he would supply me with proper food, till our arrival at Cabra; thus I was much better fed, than I had previously been, for the captain, who was not very scrupulous, took no notice of the Rhamadan, and, indeed, lived very well for that country.

In the course of the night we were awakened by the roaring of wild beasts.

On the 12th of April, at five in the morning, we stood to the east; the river continued narrow, but deep; its width, however, was still nearly equal to that of the Senegal at Podor; about eight o'clock it made an elbow to the south, and became narrower. This part of the river may be called the dungeon, the name given to a particular part of the Senegal which is extremely narrow. The country on all sides is low and damp, and very bare; at the narrow part of the river, $\mathrm{I}$ have just mentioned, there are several marshy islands, some of which are flooded all the year round; we also observed four great arms, two on each side. The river seemed to lose itself in the marshes, the banks being so low that, even at this season, they are well nigh overflowed.

These marshes, extending as far as the eye can reach, are covered with pasturage, and frequented by multitudes of water-fowl of every species; by numerous herds of cattle, sheep, and some horses, breaking, by their various cries, the silence of these desert regions. These herds belong to the voL. II. 
pastoral Foulahs, who came to the river's side to sell us their milk; they wanted to barter it for tobacco, of which we had none to give them; we were, consequently, obliged to go without their milk, for they would not accept cowries in exchange.

When, by the overflowing of the river, all the marshes are covered to the depth of eight or ten feet, this immense plain forms a vast lake; at those periods, the tribes of pastoral Foulahs, who have their huts in the neighbourhood, are obliged to retire into the interior, where the pasture is abundant during the rainy season. Continuing our course till ten o'clock in the morning, we found the river bend to the north; at this part, a very wide arm, branching from the river, extended to the east.

About eleven we passed Salacoila, a village of the wandering Foulahs, situated on the right bank; they build their huts on the quicksands. I went ashore with a negro to purchase a little milk, and saw some of the women, who were pretty well dressed; they would not take our cowries, but wanted millet or rice in exchange. They seemed very gentle in their manners; I visited their little habitations; they are of a circular form, made of a very pretty kind of matting, manufactured in the place; this is laid on poles which are fixed in the ground, and which, being flexible, curve inward at top; seven or eight of these huts were surrounded by quickset hedges of celane, a euphorbious plant which grows spontaneously on the sandy shores of the Senegal; these huts were very neat, being cleanly swept in the inside : they had no other furniture than a few mats spread on the ground, by way of bedding: some calabashes, wooden plates and skins for holding milk, were the only domestic utensils I saw. These Foulahs have the same cast of features and the same resemblance one to another as those in the neighbourhood of the Senegal; they, however, speak another language, though they perfectly understand that which is spoken at Timbuctoo. 
The only dress of the women was an apron tied round their waists. They were all exceedingly clean, and I do not think their hair was greased. They came in crowds to see me, being very curious, and apparently, very devout, for when I was going away they took up some sand in their hands and earnestly requested me to pray over it.* I complied with their wishes, gravely muttering some verses of the Koran. They then carefully rolled up the sand in their aprons, with the intention of preserving it as a precious talisman. The nenuphar (nymphaa carulea) grows in abundance in the immense marshes which surround'Salacoila. The largest species of this plant bears a beautiful blue flower. The inhabitants gather and dry the seed, and it affords them a valuable article of food. They also procure grain from the canoes which come from Jenné.

I observed the river sensibly widening. Its direction still continued northward. About two o'clock we stopped for some canoes that were astern of us. At four we again pushed off, steering to the N.E. The river now widened considerably. About ten we halted for the night. Here we again observed many hippopotami sporting about in the water. The negroes hunt this animal and sell its flesh, which they esteem very highly.

On the morning of the 13th of April, we continued our course to the north. I occasionally observed some alligators proudly rearing their heads to the surface of the water, and apparently threatening any one who might be bold enough to attack them. Scarcely had we proceeded three or four miles when we were obliged to halt to assist a canoe which had sunk. The crews of all the vessels were dispatched for this purpose, and the whole cargo was saved, but not without considerable difficulty. Every one assiduously exerted himself to dry the wet merchandise, and stow it again.

* This custom also prevails on the Senegal.

D 2 
During this disorder the whole cargo was lying on the shore exposed to the depredations of the sailors, who would have made no scruple of appropriating any article to themselves, had not guards been stationed here and there to watch them. When the cargo was once more in safety, the men who had rescued it were paid with millet. We then prepared to advance, leaving the owners and crew of the wreck to wait till they could get another canoe from 'Timbuctoo. Fortunately for them there was no village near, or part of their cargo would in all probability have been carried off.

About noon we took an easterly direction ; the river continued wide, its banks low and adorned with a few bushes. Along the shore I observed the traces of elephants, who inhabited the neighbouring woods. I was anxious to see one of these animals, but could not gratify my curiosity. It is strange that, during my long wanderings in the interior of Africa, which, according to the accounts of many travellers, is infested with wild beasts, I never met with one. At sun-set the river took a turn to the north. About nine in the evening we stopped to rest for the night; the heat had been excessive.

At five on the morning of the 14th of April we again started. Half an hour after sun-rise we passed two little islands pretty close to each other; here I observed a large arm of the river running W.S.W. At a little distance northward were two hills, which did not appear very high.

At seven in the morning we found the river turning N. E. and about nine o'clock it began to flow due east, in which direction it continued for four or five miles; then again it turned N.E., and about two in the afternoon we found ourselves before the little village of Diré, a dependency of Timbuctoo. As far as I could judge, I should suppose it contained about 150 or 200 inhabitants. Their houses are built of earth, and have terraced roofs. In an arm of the river which branched off in the neighbourhood of the village, there were six vessels of sixty tons burthen, on their way 
from Jenné. They had been waiting for us sixteen days. The Soorgoos or Tooariks would not allow them to pass without the payment of a ransom. These robbers daily went on board the canoes to levy contributions of food. The Soorgoos are a wandering tribe who inhabit the banks of the Dhioliba. They contrive to make themselves feared, and live at the expense of the poor negroes, whom they make their tributaries. I shall describe them more fully hereafter. The vessels which had been so long detained, joined us, firing muskets in token of their joy. The negroes of Diré, who are tributaries of the Soorgoos, informed us that the latter were absent, and that consequently we should escape the annoyance of their visits. In company with the canoes which had joined us, we now proceeded about four miles to the north-east, and afterwards turned due east. At sun-set we were overtaken by a violent storm, and we gained the right bank of the river, to which we moored our canoes with pikes made for that purpose. From N.E. to S.W. the sky was overspread with clouds driven by a gale, which continued part of the night. It did not raise the sand, but the heat was very great.

At six o'clock on the morning of the 15th of April, we took an easterly direction, and shortly afterwards I observed the river turning S.E. It was still as wide and deep as before, and its banks were very low. A few dwarf trees were growing in the plains. I was astonished to see so vast a mass of water, notwithstanding the idea I had formed of the magnitude of this river before my departure. The Senegal is but an ordinary river in comparison with this, which, at the season here referred to, was nine or ten feet deep. The current is scarcely perceptible; I should think about a knot and a haif an hour. About eight in the morning we passed an island, on which grow some low shrubs. We proceeded but slowly, having to wait for the large canoes, which could not advance so rapidly as we did. 
About half past eight in the morning we lay to for half an hour before the island. We saw the little village of Khokhoola, which like Diré, is a dependence of 'Timbuctoo. Here we met a little canoe which had left that city on the preceding morning. She had on board several of the Soorgoos, who exact a maintenance for themselves as far as Salacoila, where they stop, and then get conveyed home by some returning canoes. If they cannot obtain a conveyance in this way, they travel home by land. At Khokhoola the rivel takes a little turn to the N.E. and then to the north. The Soorgoos were waiting for us in the village, having been informed of our expected arrival.

They came on board the canoes, being rowed, from the shore, in little boats of their own. They were supplied with rice and water and honey mixed, a beverage of which they are exceedingly fond, and which they call Jenné-hari (water of Jenné.) These vagabonds levy their exactions without moderation. We did not allow them to come on board our canoe; we handed them out a bag of rice and they went away to importune some of our companions. When they are on board the canoes, and the negroes want to get rid of them, they fire a musket close to their ears, and they speedily take their departure, for they are very much afraid of gunpowder. They themselves never make use of fire-arms.

During the visit of the Soorgoos I was directed to go below, to avoid being seen by them; for, when they see a Moor on board, especially if his colour be lighter than usual, they assert that he is richer than the rest, as if his fortune depended on his complexion. 'They then become extremely troublesome, and will not suffer the canoes to depart without exacting a contribution from the white man, whom they call almankoye (the rich man.)

I was afterwards informed that these savages had detained on shore a Moor, whose complexion was, unluckily, not very dark, and who was imprudent enough not to conceal 
himself. They extorted merciless contributions from him. The Moors, aware of this danger, are accustomed to conceal themselves in the canoes, and only quit their hiding-place during the night.

The negroes only have the privilege of remaining on deck ; they are looked upon as an inferior class, who have not much to give, and are merely the servants of the Moorish merchant.

Wishing to see without being seen, I made several holes in the matting that covered that part of the canoe in which I was concealed. In this place the heat was so excessive, that it gave me a violent head-ache. The Moorish merchants of Timbuctoo have no authority over these robbers : not one of them would have ventured among the Soorgoos to claim the six canoes which were so long detained. If they had, they would have been sure of being laid under contribution themselves; yet, they frequently make presents to the Soorgoos.

Each flotilla that navigates the river has a chief called the amiroo, aud it is he who determines the periods for halting and starting; he is always the oldest man among the crews; it is his business to settle the amount of the contributions with the Soorgoos : though he has some influence over them, yet he can do nothing in behalf of the Moors, and if the Soorgoos see one on board his canoe, they become refractory, and often proceed to the utmost extremities to obtain what they want. "If you were not worth a single cowrie," said the negroes of our canoe to me, "they would declare that you were very rich, and you would be obliged to give them something before they would allow us to proceed."

The river, after flowing three or four miles to the north, turns to the east, and then to the N. E. ; its width still continuing the same, and its banks being uniformly low and barren. 
At eight in the evening we stopped before the little village of Cora, which, perhaps, contains two hundred inhabitants. Here we had another visit from the Soorgoos. They immediately went on board the canoe of the chief of the flotilla, to demand the contributions. Each canoe was ordered to put ashore a bag of millet for their supper, and the order was obeyed without hesitation. I was informed that the chief had engaged to pay at Cabra the exactions for allowing us to pass; which exactions consisted of millet, rice, honey, butter, manufactured stuffs, and preserved articles.

During the whole of the evening lightning flashed from the east. The heat was oppressive, and we had no rain.

On the 16th of April, we were detained at Cora until ten in the morning; the negro inhabitants of this village came to sell us milk, for which we gave them millet in exchange; they often want provisions, though they cultivate a great deal of rice; but they are continually robbed and harassed by the Soorgoos, who make these poor creatures supply them with food. At ten in the morning we stood to the N. E. There were some Soorgoos on board the canoes, and others were following us on horseback along the seashore. About one in the afternoon we lay to near some trees and shrubs, and collected a little fire-wood. At two we continued our course. At the point we reached at sunset the river turned to the north, and was very wide and deep. The sailors now used their oars instead of their poles. At eight in the evening we halted before a camp of the Soorgoo. The discussions which arose with these people occasioned considerable delay, and were a source of great annoyance, especially to me, who was shut up in my hidingplace, suffocated with heat, and only able to observe what was going on through the holes which I had made in the mats of my prison. We were continually harassed by troops of these banditti : some were in small canoes, others 
mounted on fine horses, gallopping along the shore, and by the most horrid yells instigating their companions in the canoes to board us. This tumult was insufferable. We did not entirely get rid of our tormentors until our arrival at Cabra. Every evening our canoes were obliged to give them rice and millet for their supper, in return for which they presented the chief of the flotilla with a little bull, which was killed and distributed among the masters of the different canoes. The reports of the muskets which the negroes fired before the camp, frightened the horses of those Soorgoos who had ridden from the interior for the purpose of sharing the spoil.

On the $1 \%$ th of April, at six in the morning, the flotilla stood to the north. We had not proceeded above four or five miles, when we were obliged to stop and wait for one of the great canoes which had sprung a leak, and was in momentary danger of sinking; the sailors on board set about repairing it; they plunged into the water with great agility and put oakum into the seams along the keel. About three in the afternoon all was put to rights, and we again pursued our course. The river was very wide and deep, and its banks were naked and marshy; it took a little turn to the east, and afterwards to the north : in every direction nothing was visible but marshes, without trees of any kind. At sunset the new moon was saluted by several discharges of musketry, which so terrified the Soorgoos, that they hastened ashore, and $\mathbf{I}$ heard some of them exclaim in their little canoes, "God preserve us from gunpowder !" The only arms used by these people, are lances and poniards. About seven o'clock we passed Caratoo, a little village on the right bank, and about nine, we stopped at an uninhabited place.

At five in the morning, of the 18th of April, we continued our voyage. The river turned eastward, and at seven o'clock we found its course changing to N. E. ; it then became rather narrow, the banks being all along very low and 
bare. The immense marshes on both banks were covered with cattle belonging to the Soorgoos. These herds as I have already observed, are their chief property.

At eight in the morning we stopped to say the prayer of the salam, it being the last day of the Ramadan, which the Mandingoes call Sali. We were within sight of Cabra, and the negroes testified their joy on perceiving the date trees of the village. They put on their finest dress, assembled in a large plain, and piously prostrated themselves in adoration of their God. I remained in the canoe, and observed them through the holes that $I$ had made in the matting of my prison, where the heat was suffocating. I congratulated myself that I was not required to join in these religious ceremonies, and secretly offered up a prayer that my enterprise might be favoured by Heaven. Their devotions being ended, the negroes went to dinner, and good cheer compensated for their past abstinence, which, however, had not been very rigorously observed. An easterly wind obliged us to pass some part of the day at this spot.

About four in the afternoon it became somewhat calm, and preparations were made for pursuing our voyage; but the Soorgoos opposed our departure until they had received four sacks of millet from each boat, independently of the duties we should be obliged to pay them on arriving at Cabra. This exaction on their part led to a long discussion : all the masters of canoes gathered round the chief of the flotilla, attended by the chiefs of the Soorgoos, and each party defended their own interests and those of their employers with considerable warmth. The Soorgoos were not inclined to abate their demands; but, by dint of entreaty and resistance, the contributions were reduced to one-half the amount which had been at first demanded.

About nine in the evening the canoes received orders to send on shore two sacks of millet; which was done without delay. These sacks were of the height of a man, and as 
wide as the sacks commonly used in France. I suppose they might contain nearly two hundred pounds of grain. Never did any day appear to me so long and tedious as this. I was almost within sight of Timbuctoo, and durst not shew my face : I was obliged to hide myself the whole day; and, if at any time the Soorgoos came on board, the crew obliged me to muffle myself up in a large woollen wrapper, and to pretend to sleep. At night I left my prison, for then the Soorgoos could not distinguish my complexion from that of the negroes, and 1 breathed the pure air until day-break.

On the 19th of April, at five in the morning, we stood to N.E., and at sun-rise passed a large branch of the river, which flows for a short space to W.S.W. About seven o'clock we found ourselves near a camp of Tooariks, the aspect of which was most miserable. The tents which the Moors inhabit on the right bank of the Senegal are palaces in comparison with the dwellings of these savages : a few stakes, three or four feet high, supporting a covering of untanned bulls' hides, and encircled by mats, in the form of a palisade, compose the abode of the chief, as well as of his meanest sujects. The interior of these habitations appeared to correspond perfectly with their exterior.

As we were very near the shore, I could observe a woman who had the clear copper complexion of the Moorish females, whom she still further resembled in dress : she was enormously fat, and was sitting on a sheep-skin spread on the ground; she was doubtless amusing herself by looking at the vessels as they passed. During my travels among the Braknas I never saw a woman who had attained such a degree of corpulency, though that quality constitutes the principal charm of female beauty among these people. This Tooarik Venus must have required four slaves at least to assist her in walking. The river now turned a little to the east. After having passed the camp, we came to a large island, off which we halted till eight o'clock, having to wait 
for some boats, which could not proceed as fast as ours. This island is very flat and sandy, but I observed some specimens of the mimosa, balanitis agyptiaca, and other stunted shrubs.

About nine o'clock we again put off, and at ten arrived at a place where the river separates into two branches : the principal of these might be three-quarters of a mile broad, running gently E.S.E.; the direction of the other is E. by $\mathbf{N}_{\text {. }}$; it is deep, and its breadth is from thirty-five to forty paces.

About one o'clock P.M. we arrived at the port of Cabra, and I was informed that I might quit my prison, the Soorgoos having remained behind; I speedily went on deck, whence I could see nothing around me but flooded morasses covered with aquatic birds. This arm of the river is very narrow, and the current stronger than in the large arm. I think it not unlikely that at a little distance it joins the Dhioliba, for in this place the branch inclines to the east. If this is the case, the river forms a large marshy island, which must be flooded during the inundations.

Across these immense marshes is discovered the village or little town of Cabra, situated on a small hill, which protects it from inundation. I was told that in the rainy season these marshes are covered with water to the depth of ten feet, which appeared to me a surprising depth for so vast a space, and that at those periods large vessels cast anchor before Cabra. A little canal leads to this village; but small boats only can enter the port. If the canal were cleared of the grass and nenuphars which choke the passage, vessels of twenty-five tons burthen might go up it in all seasons; but such a task would be too toilsome for the negroes.

I embarked on board a small canoe, in company with the Moors from Adrar, to proceed to Cabra.' The negro slaves hauled the canoe along by a rope, as the pole would not have been sufficient to move it. We met several small 
canoes which had been dispatched for the purpose of conveying to the town the most valuable commodities brought by the vessels from Jenné. About three in the afternoon we reached Cabra, which is situated three miles to the north of the great port. On entering it I observed a number of straw huts like those of the Foulahs, which were inhabited by trading slaves. Near their huts was a great quantity of the fruit of the nenuphar, which constitutes part of the food of the slaves and poorer classes.

I observed in the streets a great concourse of people and merchants; some walking idly about, others endeavouring: to dispose of their goods, consisting of fish, milk, colat-nuts, pistachios, \&c. The town of Cabra is narrow, and extends east and west; the houses are built of earth with terraced roofs, and have only a ground-floor; few of them are well built, being chiefly cabins, for the richer class of people prefer living at Timbuctoo, the centre of commerce. The inhabitants of Cabra, about a thousand or twelve hundred in number, are all employed, either in landing the various merchandise brought from Jenné, or in conveying it to Timbuctoo. For this purpose they make use of asses and camels. The slaves do not carry loads on their heads; this would be a bad speculation for their masters, for the poor creatures would soon be worn out, as the road leading to the town consists of quicksand which renders walking very difficult.

At Cabra a market is daily held for the sale of all sorts of merchandise from Soudan. The town contains a little mosque, surrounded by a tower or minaret. To the west of the town there are some specimens of the balanitis agyptiaca, and small gardens of tobacco; this latter plant, however, does not thrive, and seldom grows higher than six or seven inches. On the east side there are some date-trees, which are visible from a distance.

The almost constant inundation of the marshes, in the, 
neighbourhood of Cabra prevents the inhabitants from cultivating rice; and the sandy soil on the north is unfit for growing millet. The Moors from Adrar, in whose boat I had come from the great port, having unloaded the canoe, placed their goods in a store-house, until they should be ready to convey them to the city. The inhabitants of Cabra let their magazines to merchants, who wish to deposit their goods in the town; and they also let out asses for carrying loads to Timbuctoo.

I went out to take a view of the interior of the village. The streets are narrow, but neat. I saw several female traders, and from one of them I bought a little milk and a loaf of wheaten flour, which cost me twenty cowries. I made a hearty breakfast, for I had not tasted any thing all day. I had not cause to think much of the honesty of the woman from whom I made the purchase, for she wanted to make me pay twice. I was foolish enough to pay her beforehand; it is the custom in this country to lay the value of what is bought on the basket in which the goods lie, and the money is not removed until the article is in the hands of the purchaser. This precaution does not say much for the honesty of either buyers or sellers.

I saw in the port a number of large canoes undergoing repair. The owners are accustomed, as soon as the boats are unladen, to draw them on shore, where they are supported on large round blocks of wood, which keep them a little elevated from the ground. Were it not for this prudent practice, the cords with which the planks are fastened together would very quickly rot. The little port of Cabra extends east and west for the space of half a mile, being about sixty paces broad. It would be a very useful place, were it kept in better order; but it is very dirty and full of mud. Numbers of men and women áre always ready in the port to load and unload the vessels. This was the day for celebrating the conclusion of the Ramadan. The inhabitants were dancing and indulging 
in their simple demonstrations of joy. They were all decently clothed. I asked a female slave, who was sitting before her hut, for some water to drink. She immediately rose, and, washing a wooden bowl, brought me some water in it, which she presented to me with great civility.

The Soorgoos, or Tooariks, receive at Cabra the duties which they levy on vessels. They roam about the village, and behave in the most arbitrary way, making the inhabitants give them provisions and other property-in fact, seizing whatever they can lay their hands on. The inhabitants of Cabra took no notice of me. The Moors of Adrar invited me to partake of their supper of rice, which I found very palatable; and I passed the night in the open air, sleeping on a mat beside my companions. I was a little tormented by the mosquitoes, which, however, are not so common on the banks of the Dhioliba as on those of the Senegal.

On the 25th of April, the merchants of Timbuctoo came to Cabra, to land their goods. They were mounted on excellent horses. Sidi-Abdallahi Chebir, to whom I had been directed by the sherif of Jenné, did not come; but he sent his slaves. They were all well clothed, and armed with a common kind of muskets, made at Tunis. Sidi-Mbark, the owner of the canoe which had conveyed me to Cabra, had arrived at Timbuctoo several days before us, and had mentioned me to Sidi-Abdallah Chebir. He, consulting only the duty imposed on him by his religion (for he had not yet received the letter of his correspondent in my behalf) ordered his slaves to congratulate me on my happy arrival, and to invite me to visit him. This message led me to augur a good reception from him. 


\section{CH A P T E R X I.}

Journey from Cabra to Timbuctoo.-First view of the city.-The Kissoors. - The king grants the traveller an audience.-Condition of the slaves. -Description of the city, its buildings, extent, and commerce.-Food and dress of the people.-Bousbéhey, a city of the Zawats.-Toudeyni.

-Tribe of Salah.-Terror inspired by the Tooariks.-Description of that tribe.-The Ginbulas.-Particulars respecting the fate of Major Laing. - Reflexions on the means of penetrating to the centre of Africa.

ON the 20th of April, at half past three, I set out for Timbuctoo, escorted by Sidi-Abdallah Chebir's slaves. Our road lay northward. The slaves who had been on board our canoe also accompanied us, so that we formed a numerous caravan. The youngest slaves were mounted upon asses, as the road is very sandy and wearisome. Near Cabra we passed two lakes, the banks of which were overgrown with mimosas from five to six feet high. A little further the eye was refreshed by some signs of vegetation. The country presented the same scenery until we had proceeded half way on our journey, and then it began to be more naked, and the sand becoming exceedingly loose, rendered. travelling very difficult. On the road we were followed by a Tooarik, mounted on a superb horse. This marauder, who appeared to be about fifty years of age, shewed a disposition to appropriate to himself a young negro slave. Sidi-Abdallah Chebir's men represented to him that the slave belonged to their master, and that if, on arriving at the city, he would pay him a visit, he would doubtless receive a present. This appeared to satisfy him, and he ceased to molest us. He eyed me narrowly, and several times inquired who I was, and whence I came. They told him I was poor, and he relinquished the hope of getting any thing from me. 
At length, we arrived safely at Timbuctoo, just as the sun was touching the horizon. I now saw this capital of the Soudan, to reach which had so long been the object of my wishes. On entering this mysterious city, which is an object of curiosity and research to the civilised nations of Europe, I experienced an indescribable satisfaction. I never before felt a similar emotion and my transport was extreme. I was obliged, however to restrain my feelings, and to God alone did I confide my joy. With what gratitude did I return thanks to Heaven, for the happy result which attended my enterprise! How many grateful thanksgivings did I pour forth for the protection which God had vouchsafed to me, amidst obstacles and dangers which appeared insurmountable. This duty being ended, I looked around and found that the sight before me, did not answer my expectations. I had formed a totally different idea of the grandeur and wealth of Timbuctoo. The city presented, at first view, nothing but a mass of ill-looking houses, built of earth. Nothing was to be seen in all directions but immense plains of quicksand of a yellowish white colour. The sky was a pale red as far as the horizon: all nature wore a dreary aspect, and the most profound silence prevailed; not even the warbling of a bird was to be heard. Still, though I cannot account for the impression, there was something imposing in the aspect of a great city, raised in the midst of sands, and the difficulties surmounted by its founders cannot fail to excite admiration. I am inclined to think, that formerly the river flowed close to Timbuctoo; though at present it is eight miles to the north of that city, and five miles from Cabra, in the same direction.

I took up my abode with Sidi-Abdallahi, who received me in the most friendly manner. He had already been indirectly acquainted with the alleged circumstances, which, as I pretended, had occasioned my journey across the Soudan. He invited me to sup with him; and an excellent

VOL. II. 
couscous of millet and mutton was served up. Six of us partook of the dish, and we ate with our fingers; but in as cleanly a way as was possible under such circumstances. SidiAbdallahi, according to the custom of his countrymen, did not say a word to me. He was a mild, quiet, reserved man. His age might be about forty or forty-five. He was five feet high, stout and pitted with the small-pox. His countenance was pleasing, his manners grave, and rather dignified. He had no fault but his religious fanaticism.

After bidding my host good night, I went to repose upon a mat which was spread upon the ground in my new lodging. At Timbuctoo the nights are as hot as the days, and I could get no rest in the chamber which had been prepared for me. I removed to the court adjoining the house, but still found it impossible to sleep. The heat was oppressive; not a breath of air freshened the atmosphere. In the whole course of my travels I never found myself more uncomfortable.

On the morning of the 21st of April, I went to pay my respects to my host, who received me with affability; afterwards I took a turn round the city. I found it neither so large nor so populous as I had expected. Its commerce is not so considerable as fame has reported. There was not as at Jenné, a concourse of strangers from all parts of the Soudan. I saw in the streets of Timbuctoo only the camels, which had arrived from Cabra laden with the merchandise of the flotilla, a few groups of the inhabitants sitting on mats, conversing together, and Moors lying asleep in the shade before their doors. In a word, every thing had a dull appearance.

I was surprised at the inactivity, I may even say, indolence, displayed in the city. Some colat-nut venders were crying their goods in the streets, as at Jenné.

About four in the afternoon, when the heat had diminished, I saw several negro traders, all well clothed and mounted on good horses richly harnessed, go out to ride. 
Prudence forbids them to venture far from the city, for fear of the Tooariks, who would make them pay dearly for their excursions.

In consequence of the oppressive heat the market is not held until three in the afternoon. There were few strangers to be seen except the Moors of the neighbouring tribe of Zawât, who often come hither; but in comparison with Jenné, the market is a desert.

At Timbuctoo, it is very unusual to see any other merchandise except what is brought by the vessels and a few articles from Europe, such as glass wares, amber, coral, sulphur, paper, \&c.

I saw three shops kept in small rooms, well stored with stuffs of European manufacture. The merchants put out at their doors cakes of salt for sale, but they never exhibit them in the market. Such as do business at the market have stalls made of stakes covered with mats, to protect them against the heat of the sun. My host Sidi-Abdallahi was obliging enough to shew me over one of his magazines in which he stowed his European merchandise. I observed there many double-barrel guns, with the mark of SaintEtienne, and other manufactories. In general French muskets are much prized, and sell at a higher rate than those of other nations. I also saw some beautiful elephants' teeth. My host told me that he procured some from Jenné, but the larger ones had been bought at 'Timbuctoo; they are brought hither by the Tooariks or Soorgoos, the Kissoors, and the Dirimans, who inhabit the banks of the river. They do not hunt the elephant with fire-arms, but catch it in snares. I regret having never seen one of these animals caught.

On the 22nd of April, Sidi-Mbark, to whom I had made a present of a piece of cloth with the view of gaining his friendship, told me he should have a caravan ready in two days to go to 'Tafilet, and that I must hold myself pre- 
pared to accompany him to the great desert. This information vexed me, for I was not disposed to quit Timbuctoo so soon. I did not, however, lose all hope of prolonging my stay in that city.

In the evening I mentioned Mbark's proposition to my host, adding that I was greatly fatigued by the long journey I had performed on foot, and that I wished to rest at Timbuctoo for about a fortnight, after which I would avail myself of the first caravan that might depart. I had scarcely expressed this wish, when he interrupted me, saying in the kindest manner: "You may remain here longer than a fortnight, if you please. You will gratify me by so doing ; you shall want for nothing." I gratefully thanked him for his generous hospitality. Shortly after I had another instance of his kindness, for which I was very grateful. He had at first given me a chamber to myself; but the Mandingo negro by whom I had been so ill treated on board the canoe, on his arrival in Timbuctoo, quartered himself and his female slave in my apartment. I bore this patiently for some days; but the presence of the intruders prevented me from taking my notes which I could only do in secret. I mentioned to Sidi-Abdallahi that I should prefer being alone; and, after reprimanding the negro, he lodged me in another house belonging to him, which was near the marketplace and opposite to that which had been occupied by Major Laing, the street only intervening between them.

Often, when seated before my door, I thought of the fate of that unfortunate traveller, who, after surmounting numberless dangers and privations, was cruelly assassinated when on the eve of returning to his country. In the course of these reflections I could not repress a feeling of apprehension, lest, should I be discovered, I might be doomed to a fate more horrible than death-to slavery! But I determined to act with caution, and not to afford any ground for suspicion. 
I found myself much more comfortable in my new lodging. Sidi-Abdallahi my host had directed a mat to be spread in my chamber, of which he gave me the key. The slaves who lived in the house were ordered to wait on me, and they brought me twice a day couscous and rice seasoned with beef or mutton.

The city of Timbuctoo is principally inhabited by negroes of the Kissoor nation. Many Moors also reside there. They are engaged in trade, and, like Europeans, who repair to the colonies in the hope of making their fortunes, they usually return to their own country to enjoy the fruits of their industry. They have considerable influence over the native inhabitants of Timbuctoo, whose king or governor is a negro. This prince, who is named Osman, is much respected by his subjects. He is very simple in his manners : his dress is like that of the Moors of Morocco; and his house is no better furnished than those of the Moorish merchants. He is himself a merchant, and his sons trade with Jenné. He inherited a considerable fortune from his ancestors, and is very rich. He has four wives, besides an infinite number of slaves, and is a zealous Mahometan.

The sovereignty is hereditary, descending to the eldest son. The king does not levy any tribute on his subjects or on foreign merchants, but he receives presents. There is no regular government. The king is like a father ruling his children. He is mild and just, and has nothing to fear from his subjects. The whole community, indeed, exhibits the amiable and simple manners of the patriarchs. In case of war, all are ready to serve; but the mild and inoffensive manners of these people afford little ground for quarrels, and when they arise the natives of Timbuctoo repair to their chief, who assembles a council of the elders, all of whom are blacks. Though the Moors are not permitted to take part in these councils, yet my host Sidi-Abdallahi, the friend of Osman, was sometimes allowed to be present at them. 
The Moors acknowledge a superior among themselves; but they are, nevertheless, amenable to the authorities of the country. I requested my host to present me to the king, which, with his usual good-nature he consented to do.

The prince received me in the midst of his court. He was seated on a beautiful mat with a rich cushion. We seated ourselves for a few moments at a little distance from him. Sidi-Abdallahi, after briefly relating my adventures, told him that I wished to pay my respects to him. I could not understand their conversation, for they spoke in the language of the Kissoors. The king afterwards addressed me in Arabic, asking some questions about the christians, and the manner in which they had treated me. After a short time we took our leave: I wished to have seen the interior of the house, but my curiosity could not be gratified. The king appeared to be of an exceedingly amiable disposition; his age might be about fifty-five, and his hair was white and curly. He was of the middling height, and his colour was jet black. He had an aquiline nose, thin lips, a grey beard, and large eyes, and his whole countenance was pleasing; his dress, like those of the Moors, was composed of stuff of European manufacture. On his head was a red cap, bound round with a large piece of muslin in the form of a turban. His shoes were of morocco, shaped like our morning slippers, and made in the country. He often visited the mosque.

There are, as I have already mentioned, many Moors in Timbuctoo, and they occupy the finest houses in the city. They very soon become rich in trade, and they receive consignments of merchandise from Adrar, Tafilet, Tawât, Ardamas, Tripoli, Tunis, and Algiers. They receive from Europe tobacco and other articles, which they send by canoes to Jenné and elsewhere. Timbuctoo may be regarded as the principal entrepôt of this part of Africa. All the salt obtained from the mines of Toudeyni, is brought hither on camels. The Moors 
of Morocco and other countries who travel to the Soudan, remain six or eight months at Timbuctoo to sell their goods, and get their camels re-laden.

The cakes of salt are tied together with cords, made of a sort of grass which grows in the neighbourhood of Tandaye. This grass is dry when gathered; but it is afterwards moistened, and then buried under ground to keep it from the sun and the east wind, which would dry it too rapidly. When sufficiently impregnated with moisture, it is taken out of the earth and platted into cord, which the Moors use for various purposes. The camels frequently throw their loads off their backs, and when the cakes of salt arrive in the town they are frequently broken. This would spoil their sale, if the merchants did not take the precaution of making the slaves join them together again. When the pieces are fastened together, the cakes are packed up again with a stronger kind of cord made of bull's hide. The cakes are ornamented with little designs, such as stripes, lozenges, \&c., traced in black. The slaves are very fond of executing these ornaments, an employment which enables them to collect a little supply of salt for their own use. In general, the slaves are better treated at Timbuctoo than in other countries. They are well clothed and fed, and seldom beaten. They are required to observe religious duties, which they do very punctually; but they are nevertheless regarded as merchandise, and are exported to Tripoli, Morocco, and other parts of the coast, where they are not so happy as at Timbuctoo. They always leave that place with regret, though they are ignorant of the fate that awaits them elsewhere.

At the time of my departure, I saw several slaves affectionately bidding each other adieu. The conformity of their melancholy condition excites among them a feeling of sympathy and mutual interest. At parting, they recommended good behaviour to each other; but the Moors frequently hurry their departure, and interrupt these affecting scenes, 
which are so well calculated to excite commiseration for their fate.

When I was at the mosque, a middle-aged Moor stepped up to me gravely, and without saying a word slipped a handful of cowries into the pocket of my coussabe. He withdrew immediately, without affording me time to thank him. I was much surprised at this delicate way of giving alms.

The city of Timbuctoo forms a sort of triangle, measuring about three miles in circuit. The houses are large, but not high, consisting entirely of a ground-floor. In some, a sort of little closet is constructed above the entrance. They are built of bricks of a round form, rolled in the hands, and baked in the sun. The walls, except as far as regards their height, resemble those of Jenné.

The streets of Timbuctoo are clean, and sufficiently wide to permit three horsemen to pass abreast. Both within and without the town there are many straw huts of a circular form, like those of the pastoral Foulahs. They serve as dwellings for the poor, and for the slaves who sell merchandise for their masters.

Timbuctoo contains seven mosques, two of which are large ; each is surmounted by a brick tower.

This mysterious city, which has been an object of curiosity for so many ages, and of whose population, civilization, and trade with the Soudan, such exaggerated notions have prevailed, is situated in an immense plain of white sand, having no vegetation but stunted trees and shrubs, such as the mimosa ferruginea, which grows no higher than three or four feet. The city is not closed by any barrier, and may be entered on any side. Within the town are seen some of the balanitis agyptiaca, and in the centre is a palm tree.

Timbuctoo may contain at most about ten or twelve thousand inhabitants; all are engaged in trade. The popu- 
lation is at times augmented by the Arabs, who come with the caravans, and remain awhile in the city. In the plain several species of grass and thistles afford food for the camels. Fire-wood is very scarce, being all brought from the neighbourhood of Cabra. It is an article of trade, and the women sell it in the market-place. It is only burnt by the rich; the poor use camel-dung for fuel. Water is also sold in the market-place; the women give a measure containing about half a pint for a cowrie.

Timbuctoo, though one of the largest cities I have seen in Africa, possesses no other resources but its trade in salt, the soil being totally unfit for cultivation. The inhabitants procure from Jenné every thing requisite for the supply of their wants, such as millet, rice, vegetable butter, honey, cotton, Soudan cloth, preserved provisions, candles, soap, allspice, onions, dried fish, pistachios, \&c.

If the vessels from Cabra should chance to be stopped by the Tooariks, the inhabitants of Timbuctoo would be reduced to famine. To obviate this misfortune, they take care to have their warehouses always amply stored with every kind of provision. I saw the magazines of SidiAbdallahi full of great sacks of rice, which keeps better than millet.

For these reasons, the vessels which come down the river to Cabra are deterred from making any resistance to the Tooariks, notwithstanding the burthen of their exactions. I was assured that, if the crews dared but to strike one of these savages, they would forthwith declare war against Timbuctoo, and intercept all communication with the port; the city could then receive no supplies.

To the W.S.W. of the town there are large excavations, from thirty-five to forty feet deep : these are reservoirs, which are supplied by the rains. Hither the slaves resort to procure water for drink and cooking. 'This water 
is tolerably clear, but it has a disagreeable taste and is very hot.

These reservoirs had no covering whatever; the water is consequently exposed to the influence of the sun and the hot wind. The excavations are dug in loose sand. I descended into the largest of them by a gentle declivity: the bottom was not quite covered with water. I remarked some veins of hard red sand; with this exception the soil was grey sand, of a coarsish grain.

Near the reservoirs are some small plantations of tobacco. This plant grows here no higher than five or six inches, and that only by dint of watering. It is the only cultivated vegetable that I observed in this country. Some negroes were engaged in gathering it; and I remarked that it had already run to seed. They dry the leaves and pound them in a mortar, and then take the powder without any further preparation. It is merely a green powder, and has not even the smell of tobacco. They bring it to market; but the richer class of people prefer that which comes from Morocco, which is of a far better quality.

The inhabitants of Timbuctoo do not smoke, but the wandering Moors who dwell in the neighbourhood of the city use pipes.

The slaves draw the water from the reservoirs in calabashes, with which they fill leathern bags, which are carried by asses. Before they proceed to work, they always amuse themselves with a short dance; for, in spite of their hard lot, they are constantly full of gaiety. On their return home, they pour the water into jars, where it cools and loses somewhat of its disagreeable taste. I saw some female slaves washing in large calabashes beside the reservoirs.

Two days' journey N.E. of Timbuctoo stands the town of Bousbéhey, built of bricks, made of a sandy clay. It belongs to the tribe of Zawât, who wander in the desert of 
that name. The inhabitants of Bousbéhey trade in salt, which they procure in the small village of Toudeyni. They possess many camels, which constitute their principal property: they drink their milk, of which they also make butter. They possess a few sheep and some horned cattle.

The merchants of Timbuctoo purchase cattle from these people, and give in exchange millet and rice; for the soil of Bousbéhey is totally barren, and scarcely furnishes fodder for the camels. The Timbuctoo merchants likewise procure salt at Toudeyni, for which they barter millet, rice, cloth, and gold.

Bousbéhey and Toudeyni, being only supplied with the grain which the merchants of Timbuctoo receive from Jenné, would of course be reduced to famine if the trade between the two latter cities should be interrupted.

The country of Salah, which is inhabited by a wandering tribe like that of Zawât, is situated on the east, and is ten days' journey from Timbuctoo, whither the people of Salah often come for the purpose of trade. They possess numerous herds of camels, the milk of which, together with the grain they procure from Timbuctoo, forms their subsistence. Sidi-Abdallahi informed me, that there was no traffic or communication by water between Timbuctoo and the country of Haoussa; because, said he, the navigation of the river ceases at Cabra.

The negroes and Moors devote their attention exclusively to trade: they possess but limited ideas of geography. All to whom I applied for information respecting the course of the river to the east and E. S. E. of Timbuctoo agreed in stating, that it runs to Haoussa, and empties itself into the Nile.* I was unable to obtain any more accurate information on this point, and the great problem of

* The word Nile is generic, as are also the terms Bahr'B $\hat{a}$, Kouara, and many similar names. 
the issue of the Dhioliba into the ocean will thus be left to the demonstration of some more fortunate traveller; but, if I may be permitted to hazard an opinion as to the course of the river, I should say, that it probably empties itself by several mouths into the Gulf of Benin.

The Moors of 'Tripoli, as well as those of Ardamas, trade with Haoussa, whither they carry European merchandise, and in exchange bring back gold, which they procure in the rich country of Wangara; they afterwards go to Timbuctoo with packages of the fine cloth of Wangara, which is woven in narrow breadths, dyed a beautiful blue, and well glazed with gum. Sidi-Abdallahi shewed me a beautiful piece; it resembled the cloth manufactured by the negroes more to the north. At Galam, in 1819, I saw a similar kind of cloth which was brought from Sego, and was made by the Bambaras. It was as well glazed as that which $I$ saw at Timbuctoo. In general, the negroes of the Senegal set a high value on this article.

As the country of Timbuctoo is entirely destitute of pasture, (for even the camels can scarcely find food) the people obtain a considerable quantity of fodder from Cabra, which the inhabitants of that town grow in the marshes, and which they dry for the purpose of selling to those who keep horses, cattle, sheep, and goats. This forage is stowed on the roofs of the houses. Timbuctoo and its environs present the most monotonous and barren scene I ever beheld. I once indeed saw a herd of camels near the town feeding here and there upon thistles which had been dried up by the scorching east wind, and on branches of the mimosa ferruginea, the long thorns of which did not prevent these animals from devouring them. I was told that these camels belonged to the Moors who journey across the great desert.

All the native inhabitants of Timbuctoo are zealous Mahometans; their dress is similar to that of the Moors. Iike the Arabs, they are allowed to have four wives each. The women attend to domestic occupations, and they are not. 
like the Mandingo females, subject to the punishment of beating. The people of Timbuctoo, who are in constant communication with the half-civilized inhabitants of the Mediterranean, have some idea of the dignity of human nature. I have constantly observed in my travels, that in proportion as a people was uncivilized the women were always more enslaved. The female sex in Africa have reason to pray for the progress of cultivation. The women of Timbuctoo are not veiled like those of Morocco: they are allowed to go out when they please, and are at liberty to see any one. The people are gentle and complaisant to strangers. In trade they are industrious and intelligent; and the traders are generally wealthy and have many slaves. The men are of the ordinary size, well made, upright, and walk with a firm step. Their colour is a fine deep black. Their noses are a little more aquiline than those of the Mandigoes, and like them they have thin lips and large eyes. I saw some women who might be considered pretty. They are all well fed : their meals, of which they take two a day, consist of rice, and couscous made of small millet, dressed with meat or dried fish. Those negroes who are in easy circumstances, like the Moors, breakfast on wheaten bread, tea, and butter made from cow's milk. Those of inferior condition use vegetable butter. Generally speaking, the negroes are not so well lodged as the Moors. The latter have great influence over them, and indeed, consider themselves far their superiors.

The inhabitants of Timbuctoo are exceedingly neat in their dress and in the interior of their dwellings. Their domestic articles consist of calabashes and wooden platters. They are unacquainted with the use of knives and forks, and they believe that, like them, all people in the world eat with their fingers. 'Their furniture merely consists of mats for sitting on; and their beds are made by fixing four stakes in the ground at one end of the room, and stretching over them 
some mats or a cow-hide. The rich have cotton mattresses, and coverlets, which the neighbouring Moors manufacture from camel's hair and sheep's wool. I saw a woman of Cabra employed in spinning these coverlets.

The natives of Timbuctoo, as I before observed, have several wives, and to these many add their slaves. The Moors, indeed, cohabit only with their slaves, and these females are employed in vending merchandise in the streets, such as colats, allspice, \&c. Some also have a little stall in the market-place, while the favourite stays at home, superintending those whose business it is to cook for the household: the favourite herself prepares the husband's meals. These women are very neatly dressed : their costume consists of a coussabe, like that worn by the men, except that it has not large sleeves. Their shoes are of morocco. The fashion of the head-dress sometimes varies; it principally consists of a fatara of fine muslin, or some other cotton stuff of European manufacture. Their hair is beautifully platted. The principal tress, which is about an inch thick, comes from the back to the front of the head, and is terminated by a piece of cornelian of a round form and concave in the centre; they put a little cushion under the tress to support it, and add to that ornament several other trinkets, made of imitation of amber or coral, and bits of cornelian cut like that just mentioned. They also anoint the head and the whole body with butter, but less profusely than the Bambaras and the Mandingoes. The great heat, which is augmented by the scorching east wind, renders this custom necessary. The women of the richer class have always a great number of glass beads about their necks and in their ears. Like the women of Jenné, they wear nose-rings ; and the female who is not rich enough to procure a ring, substitutes a bit of red silk for it; they wear silver bracelets, and ancle-rings of plated steel, the latter of which are made in the country; instead of being round, like the bracelets, are flat, and about 
four inches broad. Some pretty designs are engraved on them.

The female slaves of rich masters have gold ornaments about their necks; instead of wearing ear-rings as in the environs of the Senegal, they have little plates in the form of a necklace. A few days after my arrival at Timbuctoo I fell in with a negro, who was parading about the streets two women, whom I recollected to have been fellowpassengers with me on board the canoe. These women were not young, but their master, to give them the appearance of an age better suited to the market, had dressed them well. They wore fine white pagnes, large gold ear-rings, and each had two or three necklaces of the same metal. When I passed them, they looked at me, and smiled. They did not appear in the least mortified at being exhibited iu the streets for sale, but manifested an indifference which I could easily enough account for, by the state of degradation to which they had been reduced and their total ignorance of the natural rights of mankind. They thought that things should be so, and that they had come into this world to be bought and sold.

The negroes of the Diriman Malaka and Kissoor villages, situated on the banks of the river, come to Timbuctoo in their canoes. They bring to that market slaves, ivory, dried fish, earthen pots, and various other articles, which they exchange for glass trinkets, amber, coral and salt.

To the south of Timbuctoo there is a country called Ginbala, which extends far inland. The inhabitants are, as I was told, all Mahometans. They seldom come to Timbuctoo on account of the Tooariks, whom they dread. They are very industrious, and raise crops of millet and rice; they are hospitable to strangers, and have numerous herds of horned cattle and flocks of sheep and goats. They grow cotton, with which they manufacture stuffs for cloth- 
ing. Having nothing to fear in communicating with Jenné, they prefer trading with that place.

The Foulahs who inhabit the neighbourhood of the river also visit 'Timbuctoo. The few whom I happened to see were similar in features and colour to those of the FoutaDhialon. They were armed with several pikes.

The trade of Timbuctoo is considerably cramped by the Tooariks, a warlike nation who render the inhabitants of the town their tributaries. The latter, for the privilege of carying on their trade, give them what they demand, independently of the duties levied on the flotillas at Cabra. A refusal to satisfy them would be attended with serious consequences; for the Tooariks are very numerous, and sufficiently strong to cut off all communication between Cabra and Timbuctoo, when the city and its neighbourhood, having within themselves no agricultural resources, would be reduced to famine. The Moors entertain a profound contempt for the Tooariks, and when they would express their utmost hatred of them, they compare them to the christians, whom they suppose to be the same kind of vagabonds and depredators. I endeavoured to refute this error, which received implicit credit here. I assured them that the Europeans were not to be compared to those marauders; that, instead of robbing, they were always ready to assist and succour their fellow creatures. "But if the christians are so very good," said they, "why did you not stay among them ;" This question embarrassed me a little; but I replied that God had ordained it otherwise, and had inspired me with the idea of returning to my country to resume the religion of my fathers.

The house of my host Sidi was constantly infested with Tooariks and Arabs. These people visit Timbuctoo for the sole purpose of extorting from the inhabitants what they call presents, but what might be more properly called forced contributions. I have often seen them sit in the 
court and insist on being supplied with food until the master sent them his tribute. They always come on horseback and their horses must be provided with forage.

When the chief of the Tooariks arrives with his suite at Timbuctoo, it is a general calamity, and yet every one overwhelms him with attention, and sends presents to him and his followers. He sometimes remains there two months, being maintained all that time at the expense of the inhabitants and the king, who sometimes give them really valuable presents, and they return home laden with millet, rice, honey, and preserved articles.

The Tooariks and Soorgoos are the same people: the former name is given to them by the Moors and the latter by the negroes. They are a wandering race, and inhabit the banks of the Dhioliba from the village of Diré to the environs of Haoussa, which my host informed me was twenty days' journey E. by S. E. of Timbuctoo, situated in a vast country of the same name, watered by the river.

The Tooariks have terrified the negroes of their neighbourhood into subjection, and they inflict upon them the most cruel depredations and exactions. Like the Arabs, they have fine horses which facilitate their marauding expeditions. The people exposed to their attacks stand in such awe of them, that the appearance of three or four Tooariks is sufficient to strike terror into five or six villages. At Timbuctoo the slaves are never allowed to go out of the town after sun-set, lest they should be carried off by the Tooariks, who forcibly seize all who fall in their way. 'The condition of these unhappy beings is then more deplorable than ever. I saw some in the little canoes almost naked, and their masters were constantly threatening to beat them.

The Tooariks possess numerous flocks of sheep and herds of oxen and goats. Milk and meat are their only food. Their slaves gather the seed of the nenuphar, which is very common in all the surrounding marshes; they dry it vOL. II. 
and thrash it. It is so small that it does not require bruising; they boil it with their fish. The Tooariks cultivate no kind of vegetable. Their slaves are employed in tending their flocks and herds. They have no grain for their own use, except what they obtain from the flotillas passing from Jenné to Timbuctoo. During the swell of the waters, the Tooariks retire a little into the interior of the country, where they find good pasture. They have numerous herds of camels, whose milk is always a certain resource for them.

The Foulahs who live in the neighbourhood of the river are not kept in subjection by these savages. The Foulahs are very superior to the pu:e negro race; they are full of energy, and are too brave to submit to the degrading yoke of the Tooariks. These Foulahs do not speak the Poulh language of the Fouta-Dhialon. I addressed to them some words in that dialect which they did not understand. They speak the language of Timbuctoo; but they have also a particular dialect which they use among themselves. All those whom I saw on the banks of the river were rovers.

I sometimes saw the camels of the Tooariks employed in transporting merchandise from Cabra to Timbuctoo; but only the poorest among them would condescend to earn any thing by this sort of labour. The rich are too proud to work. They sell at Timbuctoo oxen and sheep for the usual consumption of the town. Milk is very dear and not so good as on the banks of the river.

The Tooariks have, like all Mahometans, several wives. The largest and the fattest are the most admired. To be a real beauty with them, a woman must have such a degree of obesity as will render her unable to walk without two assistants.

They are dressed like the Moorish women on the banks of the Senegal; but instead of blue Guinea stuffs they wear blue pagnes, which are brought from Jenné, and which the merchants of Timbuctoo procure for them. Those I saw in 
passing the chief's camp were very dirty, and the men did not appear to be very careful about their dress. Like the negroes of Timbuctoo, they wore a white or blue coussabe, and trowsers reaching to the ancle, such as are worn at Jenné and Timbuctoo. The slaves have breeches, like the Moors who inhabit the banks of the Senegal. The dress of the Tooariks, except as to the head, resembles that of the Moors. They wear, both night and day, a band of cotton cloth, which passing over the forehead hangs down over the eyes and even upon the nose, for they are obliged to throw back the head a little to enable them to see. After two or three turns round the head the band is passed under the nose, and made to descend a little below the chin, so that only the point of the nose is visible. They do not take it off either to eat, to drink, or to smoke. On these occasions they merely lift up this bandage, which the negroes call fatara.

The Tooariks are great smokers. They have all fine horses, which they manage ably. They are as cruel as they are warlike. Their weapons consist of three or four pikes and a poniard which they wear on the left arm ; the blade pointing upward and the hilt touching the back of the hand. To the sheath of these poniards is attached a kind of muff, through which the hand is passed; they are straight and very well made. This weapon is brought from the banks of the Mediterranean. These men also carry bucklers, of tanned ox.. hide, the workmanship of which is elegant. In their form they resemble the shields of the ancient knights, except that they are square at the extremities.* They are adorned with handsome designs, and are large enough to cover the whole body. Some' negroes of Timbuctoo have likewise bucklers of the same form, but smaller. 'The only weapons of the Tooariks, who are always on horseback, are the lance and the poniard. They do not use the bow, as the management of their bucklers would prevent them from employing that

* Like the shields of the ancient Egyptians.

F 2 
weapon advantageously, The people who compose this wandering tribe have long hair and a very swarthy complexion, like the Moors. The nose is aquiline, the eyes large, the mouth finely formed, the face long, and the forehead rather elevated. The expression of their countenance is, however, savage and barbarous. They are supposed to be of Arab origin, and in fact, in some of their customs they resemble that race; but they speak a particular dialect. They assemble in force to attack the caravans from Tripoli, but the Morocco caravans are less exposed to their depredations because their haunts are more northerly. They keep many slaves, whom they partly employ in collecting gum on the banks of the river. This gum, and also considerable quantities of ivory, they sell to the merchants of Timbuctoo.

It is astonishing that such a number of different tribes submit quietly to the yoke of these Tooariks, when, were they to come to an understanding, they could so easily rid themselves of their troublesome enemy. The Dirimans, the Ginbalas, the Kissoors, and the Moors of Zawâ and Salah, if united, would be greatly superior to the Tooariks, and could soon deliver themselves from their oppression. The Tooariks dread fire-arms, of which they make no use, while the negroes of Timbuctoo and the Moors are armed with doublebarrel guns.

The Foulahs in the neighbourhood of Jenné, led by their chief Sego-Ahmadoo, attacked the Tooariks; the Foulahs were few in number, on account of their distance from their country, and the difficulty of procuring supplies of provisions; nevertheless, they defeated the Tooariks, made a number of prisoners, whom they put to death, and carried off a multitude of slaves and cattle, which were valuable prizes to the victors. This defeat proves, that there is no good reason for the dread with which the Tooariks are regarded, and that they are really formidable to those only who fear them. Were these tributaries, supported by the 
Moors, to attempt to throw off their yoke, they would quickly succeed; but, in general, the negroes are indolent, and the Moors, being addicted to commerce, have no martial character. Sego-Ahmadoo, indignant at seeing these Tooariks, who are Mahometans, although certainly not very zealous disciples of that creed, imposing a tax on the vessels from his country, has determined to make war upon them; but he is too distant to maintain a long war. I conjecture that Mungo Park was murdered by these barbarians.

After residing four years at Jenné, or Timbuctoo, the Moors return to their own country with a little fortune; they carry with them a number of slaves; the greater part, however, prefer trading with Sansanding and Yamina, on account of the vicinity of the gold mines of Bouré, whence they obtain considerable supplies of this precious metal. The Arabs, who come from Tafilet, Adrar, Tripoli, and other countries, bring wheat to Timbuctoo: of the flour of this wheat small learened loaves are made; they are round, and weigh about half a pound each; the bread is good, and a loaf may be purchased for about forty cowries, (equal to four sous Fiench money). The rich merchants, as I believe I have already observed, eat this bread at breakfast, with tea; they have tea services which are brought from Morocco; those which I saw were made of tin, and the cups were small, like Sidi-Ulad-Marmoo's, at Jenné. All the negroes of Timbuctoo are able to read the Koran, and even know it by heart; they make their children begin to learn it very early, whether they take upon themselves the task of instructing them, or confide their education to the Moors, of whose abilities they have a high opinion. They employ writing in their correspondence with Jenné.

Provisions are very dear in Timbuctoo, and I should have been greatly embarrassed if, as at Timé, I had been obliged to maintain myself, for my means would have been soon ex- 
hausted. 'To the worthy and generous Sidi-AbdallahiChebir, I was therefore indebted for my return through the great desert. I had only merchandise to the value of thirtyfive piastres, which I reserved to buy a camel, to carry me to the sea-coast, either through the great desert, or by directing my course westerly. I confess that the idea of crossing the Sahara in so dry a season was accompanied by not a little alarm; I was afraid that, with my slight resources, I should not be able to support the privations and fatigues of such a journey, augmented, as they must be, by a scorching wind, which blows unceasingly and renders the heat intolerable. However, after mature reflection, I resolved to encounter the dangers to which the great drought could not fail to expose me, and to venture with a caravan among the moving sands of the desert. I reflected that if I should return by the way of Sego, Sansanding, and our establishments at Galam, those who might envy the success of my enterprise, the very undertaking of which had created for me many enemies, would pretend to doubt the fact of my journey and of my residence at 'Timbuctoo, whereas, by returning through the Barbary states, the mere mention of the point at which $I$ had arrived would reduce the most malignant to silence.

Sidi-Abdallahi daily lavished on me marks of his kindness; he even went so far as to urge me to remain in Timbuctoo. He said he would give me merchandise to trade on my own acccount; and, observed, that when I should have accumulated sufficient profit, I might return to my own country without assistance from any one. However, the fear of being discovered, joined to a strong wish to re-visit my native land, induced me to decline his generous offers. I considered, moreover that, as my departure for the interior of Africa was not authentically known, even that circumstance would be buried in oblivion, were $I$ to perish, and the observations I had made would be lost to my country. Influenced by these considerations, I resolved to endeavour to 
return as speedily as possible. As the opportunity on which I relied, was likely to occur soon, I did not neglect to take advantage of the short time which would probably be at my disposal. I visited the great mosque on the west side of the town; it is larger than that on the east, but is built in the same style. The walls are in bad repair, their facing being damaged by the rains, which fall in the months of August and September, and which are always brought on by easterly winds, accompanied by violent storms. Several buttresses are raised against the wall to support thern; I ascended the tower, though its staircase, which is internal, is almost demolished. I returned several times to make my notes, for in this little frequented spot I was not afraid of being observed. During these travels, I always endeavoured to conceal myself while writing, lest I should awaken the suspicion of the Moslems : I always endeavoured to get into a wood, or placed myself under the shade of a bush or a rock, when I wished to commit what I thought worthy of remark to writing.*

From the tower I had an extensive view over an immense plain of white sand, on which nothing grows except a few stunted shrubs, the mimosa ferruginea, and where the uniformity of the picture is only here and there broken by some scattered hills or banks of sand. I could not help contemplating with astonishment the extraordinary city before me, created solely by the wants of commerce, and destitute of every resource except what its accidental position as a place of exchange affords. The western quarter of the mosque seems very ancient, but the whole façade on that side is in ruins. There are also some vaulted arcades, from which the whole of the plaster facing is detached. This

* When I wrote in the desert, I sat down and placed on my knees some leaves of the Koran, which I was supposed to be copying and studying. See plate 3 . 
mosque is constructed of sun-dried bricks, of nearly the same form as those made in Europe. The walls are roughcast with a kind of coarse sand, similar to that of which the bricks are made, mixed with the gluten of rice. In some parts of the desert there is found a very hard ask-coloured earth, in which sand predominates. This earth has been used in making the bricks for the mosque. The rest of the edifice appears to have been built after the western part was in ruins. Though the new part is very well for a people ignorant of architecture, it is greatly inferior to the ancient remains.

I was surprised to find in the ancient part three galleries, each supported by ten arcades, as well built as if they had been the work of a skilful architect. The arches are six feet wide and ten high; there the plaster is in an excellent state, and appears to have been white-washed. The style and the position of this building connect it with the ruins. I am inclined to think that the mosque consisted originally of this part only, and that additions were afterwards made to it.

The eastern part is composed of six galleries; those of the west are supported by nineteen pillars. The apertures are each six feet and a half wide, and ten or eleven high. The workmanship, though pretty well executed, is, as I have already observed, far from equalling that of the other quarter. The first three galleries on the east side, are one hundred and four ordinary paces* long, and about two and a half broad : the three next are only sixty-four long. The length of those on the west is only thirty nine paces. They lead to the great tower, which faces an inner court, closed on the west by the ruins. It is of a square form, but terminates in a small truncated pyramid, which is also built of brick and surmounted by a pot of baked earth.

* Of about two feet. 
Its height may be estimated at fifty or fifty-five feet from the base to the summit. The steps of the staircase, which is constructed internally, are supported by pieces of wood fixed in the walls and covered with earth. The dilapidated state of the staircase prevented me from ascertaining the exact number of the steps, but I observed the traces of thirty-two.

The walls of the mosque are fifteen feet high and twentyfive or twenty-six inches thick. 'The top of the wall of the east front is indented in the form of battlements, the salient parts of which are surmounted by puts of baked earth, similar to that on the summit of the tower.

Another massive tower, of a conical form, surmounts the front wall. It is about thirty feet high. On the dome, projecting pieces of wood are perceptible, the use of which seems to be to unite the masonry.

The roof of the mosque has a terrace like that of the tower, and is moreover surrounded with a parapet eighteen inches high.

The roof of the building is supported by rafters, formed of the trunks of the ronnier tree split into four, and placed at the distance of a foot from each other. Pieces of salvadora wood, brought from Cabra, where it grows in great abundance, cut to the length of the intervals between the rafters, are placed obliquely in double rows, crossing each other. Over these are laid mats made of the leaves of the ronnier, which are covered with earth.

This mosque has five gates of different sizes on the eastern side, three on the south side, and two on the north. On the western side the ruins form at once the boundary of the mosque and of the city. On the eastern and northern sides, the floor of the building is level with the ground; but on the south is an ascent of four steps.

On the eastern wall, in the interior of the building, there are some ornaments made of yellow clay. They are in the form of a chevron or triangular festoon, two feet high, 
with an opening of a foot and a half. They commence about eighteen inches above the ground. The pillars supporting the arcades in front, have some ornaments of the same material tolerably executed, but very much defaced. A kind of niche, in the centre of the eastern wall, is destined for the marabout who officiates at prayers. In another similar niche there is a large wooden pulpit, into which the priest ascends by two or three steps, on the days when he reads certain passages of the Koran. The floor of the mosque was covered with mats, on which the people kneel during prayers.

Conceiving that the description alone would not convey an adequate idea of the construction of this mosque, I ventured to make a sketch of it, as well as of the town; both would, I thought, convey a better idea than words alone of the objects with which I wish to make the reader acquainted*.

To make my sketch of the mosque, I sat down in the street in front of it, and, covering myself in my large wrapper which I folded over my knees, I held in my hand a sheet of white paper close to a leaf of the Koran. When I perceived any one approaching, I hid my drawing, and looking at the leaf of the Koran I appeared to be absorbed in devotion. The passers-by, far from suspecting me, regarded me as one of the elect, and applauded my zeal $\uparrow$.

The eastern mosque is much smaller than that on the western side. It is surmounted by a square tower, similar in form and dimensions to that of the western mosque. The walls are entirely stripped of their parget. Many buttresses have been erected to support the building. It has three arcaded avenues. The galleries are six feet wide and thirty feet long.

* See plates 4 and 5.

+ See plate 3 . 
The mosque itself is thirty paces long and five and twenty wide. The arcades which are three feet and a half wide and seven and a half high are built of the same bricks as those of the western mosque. There is an inner court, which must be passed through before we can ascend the tower. No part of this mosque is in ruins, though it appears very old. It is not very regularly built. I remarked that it had two gates looking to the south and one to the north. The western and eastern sides had no apertures. Near the mosque, on the eastern side, are seen a small hillock of sand, and some buildings overwhelmed by the sand blown up by the east wind.

In the centre of the town is a kind of square surrounded by circular huts. Here grow some palmo christi and a palm-tree, the only one I saw in the country. In the middle of this square is a large hole, dug for a receptacle for filth. Two enormous heaps on the outside of the town appeared to me to be also collections of dirt or rubbish. Many a time have I ascended to the tops of these hills to obtain a complete view of the town and to make my sketch*.

A third and somewhat remarkable mosque stands nearly in the centre of the town. This likewise has a tower, but not so high as those of the other two. It has square arcades: the naves are seven feet wide and twenty five long. The front wall is ornamented with many ostrich eggs, some of which are also placed on the top of the tower. On the east side is a very extensive court, in the middle of which a balanites agyptiaca is planted by way of ornament. At the back of the mosque on the opposite side, some salvadoras.

There are five mosques besides those which $I$ have mentioned; but they are small and built like private houses, with the 
exception that each is surmounted by a minaret; all of them have an inner court, to which the people resort in the evening to perform their religious devotions. The criers, whose business it is to call to prayers, receive no salary; but at stated periods they announce to the faithful from the summits of the minarets that it is time to pay their contributions. I happened to be at Timbuctoo at one of these periods. Each person made his offering, consisting of bread, millet, rice, dried fish, pistachios and cowries; all these articles were deposited on a mat spread on the ground, before the door of the mosque.

It frequently happened that Moors who felt interested in my situation questioned me about European customs and the treatment I had experienced at the hands of the christians. I tried in my turn to obtain from them information concerning the neighbouring nations and the distance of their country from Timbuctoo. But, so far from satisfying my curiosity, they pretended not to hear me, and turned from me to speak to each other. Unfortunately, I had not the means of gaining their favour by presents. They called me the meskine (beggar). The litt̂le information I obtained at Timbuctoo was furnished me by my host Sidi-AbdallahiChebir, and by some Kissour negroes. These were the only individuals who had the civility to reply to my questions. They had no definite idea of the course of the river eastward of the city. Sidi assured me, that it went to Haoussa and joined the Nilet. This is the general opinion of the Arabs of this country. This river bears at Timbuctoo the name of Bahar-el-Nil (Nile river).

The house which was appropriated for my residence not being quite finished, I had opportunity to observe the way in which the houses of this country are built. An excavation is made in the town itself to the depth of some feet, where a grey sand mixed with clay is found. This is made

* I have already observed that Nile is a generic term and does not necessarily apply to the Egyptian river. 
into bricks of a round form, which are baked in the sun. These bricks are similar to those used at Jenné. The young slaves carry them on their heads in calabashes, the way in which they also carry the mortar, which is formed from the same material. The builders, who are slaves, execute their work as cleverly as those of Jenné. I thought indeed that their walls were better constructed. Their doors are well made and solid; they are formed of planks joined with bars and nails brought from Tafilet. They fasten their doors by locks made in the country, without iron : even the keys are of wood*. Some Moors use iron locks and keys which they bring from the coasts of the Mediterranean. Locks are not used in the interior of the houses; but chains or bars supply their place. The roofs of the houses, none of which have more than the ground-floor, are, like those of the mosques, supported by rafters cut from the trunk of the ronnier, a tree which grows to a prodigious height on the banks of the river. I have seen some of these trees above a hundred and twenty five feet high. The trunk is split into four quarters, which are rounded off, laid upon the walls, and then covered with pieces of wood, mats and earth, like the roofs of the mosques.

Each house forms a square, $\uparrow$ containing two inner courts, round which are ranged the chambers, each of which is of a narrow oblong form and serves at once for a magazine and bed-room. These rooms receive light only from the door of entrance, and another very small door opening into the inner court. They have neither windows nor chimneys.

The people of Timbuctoo have not adopted the practice, which is general in the Soudan, of lighting fires in their

* Wooden locks and keys are also used in Egypt and Nubia.

+ See the plan of a private house. Plate 5, Figs. 4. 5 . 
houses. Some of them build in the court a small hut of mats, in which during summer they live day and night; the chambers being too warm.

A chamber similar to those $I$ have above described was allotted to me; but I had well nigh been suffocated in it. $I$ found it impossible to endure the heat, especially in the night. But what could $I$ do in a country where there is not a tree to cast the least shade? My only refuge was a mosque which was the coolest and most airy place I could find. The east wind too, by raising clouds of dust, darkens the atmosphere and augments the heat. The inhabitants stay within doors during the heat of the day, and only go out in the mornings and evenings. The nights bring with them an oppressive calmness of the atmosphere, and if by chance there is a breath of air, it is felt like a burning vapour, and seems almost to scorch the lungs. I was continually ill at Timbuctoo.

The caravan destined for Tafilet was not to leave Timbuctoo for some days, and I was informed that the next did not start for three months; I therefore determined to take advantage of the earliest conveyance; for I dreaded so long a stay at 'Iimbuctoo, notwithstanding the reiterated invitations of Sidi-Abdallahi, who recommended to me to take the route of Tripoli by Ardamas rather than that of Morocco. He told me that he had intended to make a collection for me, but that my speedy departure afforded him no time to do so. He assured me that, if I would remain with him some months, my subsistence should cost me nothing. I scarcely knew how to decline such kindness, but I had formed my determination; I excused myself to Sidi, by telling him that I was afraid to travel in the rainy season, and finding me obstinate he looked out for a good guide to conduct me to Tafilet.

The Moors in whose company I was about to travel 
were far from being so kind and civilized as those who reside in the city. I had had an opportunity of observing their manners before I started; for, they often came and begged of me, and made no scruple of rousing me out of my sleep. They are a class of men whom the Moors of a superior order call zenagues, (tributaries). They are very ignorant. Many of them do not know the first prayers of the Koran. They however observe religious ceremonies. A poor stranger like myself, unacquainted with their language, was in their eyes an object of contempt. I expected therefore to suffer much in crossing the desert.

Sidi-Abdallahi informed me that he had hired a camel to carry me to Tafilet. 'The thirty thousand cowries' worth of cloth, the proceeds of the sale of my merchandise at Jenné, sufficed to pay for the camel. Sidi told me that he would keep my cloth and give my guide ten mitkhals of gold, or thirty piastres.

I employed the remainder of the time I stayed in Timbuctoo in collecting information respecting the unfortunate death of Major Laing, which I had heard mentioned at Jenné, and which was confirmed by the inhabitants of Timbuctoo whom I questioned respecting the melancholy event. I learned, that when within a few days' journey of the city, the caravan to which the major belonged was stopped, on the road to Tripoli, by the Tooariks, or as others alleged, by the Berbiches, a wandering tribe, near the Dhioliba. Laing, being discovered to be a christian, was cruelly attacked, and his assailants continued beating him with a club until they thought him dead. I conclude that the other christian, who was said to have been actually murdered, was a servant of the major's.

The Moors belonging to the caravan raised Laing up, and succeeded in restoring him to animation. When he became sensible, they placed him upon a camel, but he was 
so weak that they were obliged to tie him on. The robbers left him almost destitute, having robbed him of the greater part of his merchandise.

On his arrival at Timbuctoo, Major Laing healed his wounds by the aid of an ointment which he brought with him from England. His recovery was slow; but he was made very comfortable, owing to the letters of recommendation which he had brought from Tripoli, and especially to the attention of his landlord, a Tripolitan, to whom he had been directed. The house of this Moor was near that in which I lodged at Timbuctoo. I had frequent opportunities of seeing him. He appeared to me a man full of kindly feelings. Many a time he has given me dates, from mere charity, and the day before I left he made me a present of a pair of blue cotton trowsers, to wear on my journey.

He told me that the major had been recommended by a Tripolitan house to an old Moor, who, not having convenience to lodge him, transferred him to his hospitality. Laing, he added, never laid aside his European dress, and used to give out that he had been sent by his master the King of England, for the purpose of making himself acquainted with Timbuctoo and the wonders it contains.* It would appear that the traveller had openly taken a plan of Timbuctoo, for the same Moor told me in his simple way that he had written down every thing in it.

Other Moors, whom I questioned respecting Laing, merely told me that the major ate little, and that he lived entirely on bread, eggs, and poultry. I moreover learned that he was tormented to say that there is but one God and that Mahomet is his prophet; but he always stopped at the words: "There is but one God." They then called him

* It is doubtful whether the English traveller would have expressed himself in this manner. 
cafir, and infidel, but, without ill treating him, left him free to think and pray in his own way. Sidi-Abdallahi, whom I often questioned as to whether the major had been insulted during his stay at Timbuctoo, always replied in the negative ; shaking his head, to give me to understand, that they would have been sorry to annoy him.

This toleration may be accounted for by the fact, that the Moors who reside at Timbuctoo come from Tripoli, Algiers, and Morocco, and that, being in the habit of seeing christians in their own countries, they are less liable to be offended at their worship and their manners. For instance, Sidi-Abdallahi, who came from Tatta, a lown near Cape Mogador, was not inimical to the christians. Thus it may easily be conceived that the major was free to inspect every part of the town and even to enter the mosques.

It would appear that, after he had made himself completely acquainted with Timbuctoo, he wished to see Cabra and the Dhioliba. But had he left the city in the day time he would have incurred the greatest danger from the Tooariks, who are continually roaming about the environs of Timbuctoo, and whose attack he had too much reason to remember. He determined to set off during the night. This was wise, for though the Tooariks dared not touch him while he staid in the town, they would have wrecked their vengeance on him had they caught him beyond its limits, and murdered as well as robbed him.

Taking advantage of a dark night, Major Laing mounted his horse, and, unaccompanied by a single native, reached Cabra, and even, it is said, the banks of the Dhioliba, without accident. On his return to Timbuctoo, he ardently wished, instead of proceeding to Europe by the desert, to travel by Jenné and Sego, ascending the Dhioliba, whence he might have reached the French factories on the Senegal. But, no sooner had he communicated his plan to the Foulahs 
established on the borders of the Dhioliba, (a great number of whom had resorted to Timbuctoo, on hearing of the arrival of a christian) than they all declared they would never suffer a nasarah to set foot in their territory, and if he made the attempt, they warned him that he would have cause to repent it.

The major, perceiving that he could do nothing with these fanatics, chose the route of el-Arawan, where he hoped to join a caravan of Moorish merchants, conveying salt to Sansanding; but alas! after journeying five days to the north of Timbuctoo, the caravan with which he had come up was stopped by Sheikh Hamet-oul'd-Habib, an old fanatic, chief of the tribe of Zawât, who wander in the desert of that name. Sheikh Hamet seized the major, under pretence of his having entered his territory without permission. He then wished to compel him to acknowledge Mahomet to be prophet of God, and required him even to make the salam. Laing relying too confidently on the protection of the pacha of Tripoli, who had recommended him to all the sheikhs of the desert, refused to obey Hamet, who more and more urgently insisted on his acknowledging himself a Musulman. Laing continued firm, and chose to die rather than yield; a resolution which made one of the most intelligent of travellers a martyr to the cause of science. A Moor, belonging to the train of the chief of the Zawâts, who was directed by his master to kill the christian, refused to execute his order. "What!" said he, "do you wish me to slay the first christian who has come among us, and one who has done us no injury? give the commission to another; I will not be the instrument of his death; kill him yourself." This address suspended for a moment the fatal sentence, and the question of Laing's life or death was warmly debated for some time. At length the latter was decided on. Some black slaves were summoned, and they were ordered to per- 
form the horrid deed, with which the Moor had refused to stain his hands. One of the murderers immediately tied his turban round the neck of the victim, and strangled him on the spot, he pulling one end while his comrade held the other. The corpse of the unfortunate Laing was cast upon the desert, to become the prey of the raven and the vulture, the only birds which inhabit those desolate regions.

When the major had once been discovered to be a christian and a European, death was a thousand times preferable to even a temporary change of religion, since he must have renounced all hope of again visiting Europe. The fate of Laing, had he become a Musulman perforce, would have been irremediably wretched. He would have been the slave of merciless barbarians, and exposed to all the miseries and dangers peculiar to that country; in vain would the pacha of Tripoli have demanded his liberation. At that immense distance, the chief of the Zawâts would have scorned his menaces and detained his prisoner. The resolution of Major Laing was perhaps at once a proof of intrepidity and of foresight.

On his departure for El-Arawan the major took with him some astronomical instruments and his papers, but very little merchandise, for the Tooariks had relieved him of nearly all he possessed. The Sheikh Hamet therefore gained little by the murder of the English traveller, and he was even obliged to divide that little with the wretches whom he had made the instruments of his crime. A Moor of Tafilet, who belonged to the caravan, had for his share of the spoil a sextant, which I was informed might be found in the country. As for the major's papers and journals, they were scattered among the inhabitants of the desert. During my stay at Gourland, a village of 'Tafilet, I saw a copper pocket compass, of English manufacture. Nobody could tell me whence this instrument had come, and I concluded that it had belonged 
to Laing. Had it not been for the precautions I was compelled to observe in my Arabic disguise, I would have given a good price for it ; but I could not, without betraying myself, show that. I attached the least value to an instrument, of the use of which I was supposed to be ignorant.

I have left a wide field of discovery for those who come after me, especially in the geography and natural history of this country. What I have suffered should not discourage future enquirers. Their attempts will doubtless be attended with hardships and danger; but an enterprise conducted with prudence would triumph over obstacles. To ensure success, the traveller should, I think, make no sort of display; he should externally adopt the worship of Mahomet, and pass himself off for an Arab. A pretended convert would not enjoy so much liberty, and would be an object of suspicion to such distrustful people. Besides, I am of opinion that a converted christian would not be tolerated among the negro tribes. The best plan would be, I think to cross the great desert of Sahara in the character of an Arab, provided with adequate but concealed resources. After remaining for some time in the Musulman town selected by the traveller as his starting point, where he might give himself out as a merchant, to avoid suspicion, he might purchase some merchandise in that town, under the pretence of going to trade further on, carefully abstaining from all mention of the city of Timbuctoo.

Let us suppose Tangiers or Arbate to be the place chosen as the point of departure ; mercantile business at $\mathrm{Fez}$ might be alleged as an excuse for setting off. Still adopting the same pretence, the traveller might proceed from $\mathrm{Fez}$ to $\mathrm{Ta}-$ filet, and thence to Timbuctoo. At Tafilet there would be no danger of speaking of Timbuctoo, for there a journey to the Soudan is an affair of frequent occurrence and it excites no attention. It would be advisable to purchase merchan- 
dise at Tafilet for the purpose of exportation. On reaching Timbuctoo, the traveller should settle there, establish a mercantile house; but he should above all things avoid appearing rich, and must make himself familiar with the customs of the country, and be very circumspect in every thing connected with religion.

After remaining at Timbuctoo seventeen or eighteen months, and purchasing some Mandingo or Bambara slaves speaking the Kissour and Tooarik languages, he might procure a middle-sized well built canoe, for the conveyance of merchandise and provisions. It would be necessary to take a supply of the latter, on account of the uncertainty of being able to procure them from the people who dwell on the banks of the river. By promising the slaves their liberty, they might be easily prevailed upon to undertake the voyage, the pretended object of which would be to trade in the lower part of the river, and to purchase gum, ivory, \&c. It would not be necessary to adopt all these precautions for the passage of the river above Cabra.

To lull suspicion, it would be advisable to leave at Timbuctoo a certain quantity of merchandise, under the care of a confidential slave, who might have orders to dispose of it under the direction of a Moorish merchant, during his master's absence.

Being once fairly embarked in the canoe with six slaves, good swimmers, it would be preferable to proceed onward during the night on account of the wandering tribes of 'Tooariks and others. But even if they were met during the day time, they might be got rid of with a few presents. This course, prudently and cautiously followed, would, I doubt not, be attended with complete success, and it appears to me preferable to the plan of sending numerous expeditions, which would rouse the cupidity and distrust of the natives.

The rapid passage of the little canoe would render the voyage infinitely less fatiguing and dangerous than if per- 
formed in a large vessel. Sidi-Abdallahi informed me that Haoussa was only a twenty days' passage from Timbuctoo, descending the river; but in a small canoe the passage might be accomplished in twelve days, and then the mouth of the river might be speedily reached, especially if it empties itself into the Ocean. 'This plan, I am convinced, would be far less dangerous than that of starting from the gulf of Benin, where great difficulties would always be experienced in ascending, both on account of the climate and the inhabitants. 


\section{CHAPTER XXII.}

Departure from Timbuctoo on the 4th of May, 1828.-Caravan of six hundred camels.- Entrance of the desert.-Suffocating heat.-The caravan falls in with the Tooariks.-Manner in which the Arabs direct their course in the desert.-Aspect of Sahara, like the bed of a sea without water.-Details respecting the caravans.-The place where Major Laing was assassinated.-El-Arawan, a city in the desert; its springs, population, and trade.-Information respecting Tawât and Wâlet.-Caravan of four hundred camels.-Disheartening effect of the view of endless sands.

ON parting with my host, I thanked him for his generous hospitality: though he had often declared that all the care he took of me was for the love of God and the prophet, I offered him the woollen wrapper which I bought at Kakondy, and which had been so useful to me during my long illness at Timé; I also offered him the satala or vase which I used for my ablutions. Contrary to my expectation, this excellent man declined receiving my offered presents, observing that I should want those articles in the course of my journey, and that I ought not to be deprived of then. At last, overcome by my solicitations, he consented to accept them; but, the day before my departure, he, in his turn, presented me with a cotton wrapper manufactured in the Soudan, and which was of equal value with the one I had given him. He added to this handsome present a new cotton coussabe also, that I might have a change of dress on my journey. This was not all, he presented me with a stock of provisions sufficient to last till I reached El-Arawan; and he paid all the expenses of my journey to that place, warmly recommending me to one of the inhabitants, who was his 
agent, during the stay $I$ should make there before I crossed the great desert. In short, he spared no pains to diminish the hardships of that undertaking. He also gave me two leathern bottles to hold my supply of water for the journey; some dokhnou, wheaten bread, baked in the same way as our biscuit, melted butter, and a large quantity of rice.

It was very warm during the whole of the fortnight that I stayed at Timbuctoo; the wind never ceased to blow from the east.

The caravan destined for el-Arawan, with which I had resolved to travel, was to set out on the 4 th of May, at sunrise. My host was up so early that morning as to allow me time, before my departure, to breakfast with him on tea, new bread, and butter. 'That nothing might diminish the agreeable impression which my stay at Timbuctoo had made upon me, I met, on departing, the host of Major Laing, who made me accept some new clothing for my journey.

Sidi-Abdallahi accompanied me to some distance from his house, and, at parting with me, he affectionately pressed my hand and wished me a good journey. This farewell detained me almost too long. To rejoin the caravan, which had already proceeded to a considerable distance, I was obliged, as well as three slaves who had also remained behind, to run a whole mile through the sand. This effort fatigued me so much, that, on reaching the caravan, I fell down in a state of insensibility; I was lifted up and placed on a loaded camel, where I sat among the packages, and though dreadfully shaken I was too glad at being relieved from the labour of walking to complain of my beast.

On the 4th of May, 1828, at eight in the morning, we directed our route to the north over a sandy soil, almost moving, quite level, and completely barren. However, at the distance of two miles from the town, we met with a few shrubs resembling junipers, and some rather tall clusters 
of mimosa ferruginea, which yield a gum of inferior quality. The inhabitants of Timbuctoo send their slaves hither for fire-wood. The heat was most oppressive, and tha progress of the camels was extremely slow; for, as they moved along, they browsed on the thistles and withered herbs, which they found scattered here and there on these plains. During this first day the slaves were allowed to drink at discretion, as I was. This conduct was doubtless very humane; nevertheless, I was soon shocked by an act of barbarity, which $I$ had the misfortune to see too often repeated. A poor Bambara slave of twenty-five was cruelly treated by some Moors, who compelled him to walk, without allowing him to halt for a moment, or to quench his burning thirst. The complaints of this unfortunate creature, who had never been accustomed to endure such extraordinary privations, might have moved the hardest heart. Sometimes he would beg to rest himself against the crupper of a camel, and at others he threw himself down on the sand in despair. In vain did he implore, with uplifted hands, a drop of water; his cruel masters answered his prayers and his tears only with stripes.

At Timbuctoo the merchants give the slaves shirts, such as are worn in the country, that they may be decently covered; but on the route the Moors of the caravans, who are the most barbarous men 1 ever knew, take the good shirts from them and give them others all in rags.

At five in the evening the caravan, the camels of which amounted to nearly six hundred, halted in a ravine of yellow sand, which was, however, pretty solid. Here these animals found some herbage, and the spot appeared to me delightful. A slave, who was barely allowed time to take a drink of water, was ordered to look after our camels, and we thought of nothing but how to pass the night quietly; but before we laid ourselves down to sleep, we made our supper on a cala- 
bash of water, some dokhnou, and the bread which I had received from Sidi-Abdallahi; the bread being hard we soaked it in the water, into which we put a little butter and honey. This mixture was to us a delicious beverage. The slaves had for their supper some sangleh seasoned with butter and salt. These good-natured creatures were so kind as to offer me some of their meal.

On the 5 th of May, at sun-rise, we resumed our journey. We still proceeded towards the north, upon ground similar to that over which we passed on the preceding day. A few stunted bushes were descried here and there, and also some salvadoras, which the camels devoured.

Towards noon we approached a less level region, where the ground was raised into slightly elevated mounds, all inclining in the direction from east to west. The heat was suffocating, on account of the east wind, which raised great clouds of sand: our lips were covered with it; our thirst became insupportable; and our sufferings increased in proportion as we advanced further in the desert. We fell in with two Tooariks, who were going to el-Arawan, and whom we took to be the scouts of a troop of these marauders. Fortunately they were alone. They were both mounted on one camel. On the left arm they had a leather buckler; by the side, a poniard; and in the right hand, a pike. Knowing that they should meet us in their route, they had brought no provisions with them, and trusted to the caravan for a supply. These robbers, who would have trembled at the slightest menace, if seriously made, took advantage of the terror which their name and the crimes of their tribe every where spread, and obtained whatever they demanded: in a word, the best of every thing was presented to them. On the one hand, there was a sort of rivalship in offering them whatever they chose to eat; on the other, to give them water, though it would be six days before we should come to any. At last, 
after they had staid with us three days, we had the satisfaction to see them depart, and to be delivered from their troublesome company.

At four in the evening we encamped to pass the night, during which we were oppressed by excessive heat, caused by a dead calm. The sky was heavy and covered with clouds which seemed immoveable in the immensity of space. Still the heat continued intense.

Before proceeding farther, I ought to inform the reader how I continued to make an estimate of the route. We travelled, at an average, about two miles an hour. At night we proceeded almost constantly in a northerly direction. Being afraid that my pocket compass would be noticed if $\mathbf{I}$ took it out to consult it, I judged of our course during the day by the sun; in the night, by the pole-star.

It is by this star that the Arabs are guided in all their excursions through the desert. The oldest caravan conductors go first, to lead the way. A sand-hill, a rock, a difference of colour in the sand, a few tufts of herbage, are infallible marks, which enable them to recognize their situation. Though without a compass, or any instrument for observation, they possess so completely the habit of noticing the most minute things, that they never go astray, though they have no path traced out for them, and though the wind in an instant completely covers with sand and obliterates the track of the camels.

The desert, however, does not always present the same aspect, or, consequently the same difficulties. In some parts I found it covered with rocks and gravel, which bore the traces of caravans that had passed long before. Besides, though the desert is a plain of sand and rock, the Arab commits few errors in crossing it, and is seldom wrong to the extent of half an hour in fixing the time of arrival at the wells. I ought not to omit to mention, that these wells are almost constantly found covered over, and that 
the first thing done on the arrival of a caravan is to clear away the sand.

On the 6th of May we resumed our march, at three in the morning, and continued our route to the north. Still the same soil, the same aridity, and the same uniformity, as on the preceding days.

The atmosphere was very heavy all day, and the heat excessive. It seemed as if we should have rain. The sun, concealed by clouds, appeared only at long intervals. But our prayers did not obtain from Heaven a drop of rain. In spite of all the prognostics no shower fell. The further northward we proceeded the more barren the country became. We no longer saw either thistles or salvadoras: sad consolations, where all nature wears so frightful an aspect! The plain had here the precise appearance of the ocean; perhaps such as the bed of a sea would have, if left by the water. In fact, the winds form in the sand undulating furrows, like the waves of the sea when a breeze slightly ruffles its surface. At the sight of this dismal spectacle, of this awful abandonment and nakedness, I forgot for a moment my hardships, to reflect on the violent convulsions which thus appeared to have dried up part of the ocean, and of the sudden catastrophes which have changed the face of our globe.

At eleven in the morning we halted. The heat was insupportable, and we seated ourselves beside some unhealthy looking mimosas, over which we extended our wrappers, for these shrubs being destitute of leaves afforded no shade of themselves. Under our tents thus formed, we had distributed to us a calabash of water, which was rendered tepid by the east wind. According to our custom, we threw into the water some handfuls of dokhnou. Finally, to relieve ourselves from every immediate care, we sent a slave to watch our camels, which were endeavouring to refresh themselves by browsing on some withered herbage. We then lay down to 
sleep on the sand, which at this place was covered with small stones. This was not done from indolence, but from consideration; for it was proper to wait for night to take advantage of the coolness, when we might travel more at our ease than during the day, in which the calms were sometimes more insupportable than the burning sun. During these calms I could not close my eyes, while the Moors slept soundly. The same kind of calm often prevails during the night, but then there is some compensation in the absence of the sun. In the inhabited countries, the night, or rather the latter part of the night, is always the most agreeable portion of the twenty-four hours. It is at day-break that the flowers exhale all their perfumes: the air is then gently agitated, and the birds commence their songs. Recollections, at once pleasing and painful, turned my thoughts to the south. In the midst of this frightful desert could I fail to regret the land which nature has embellished?

The caravans which traverse the desert are under no absolute commander; every one manages his camels as he pleases, whether he has many or few; some have fifteen, others six or ten; and there are individuals who possess not more than three; I have even seen some with only two, but these were very poor. Such persons join richer travellers and take care of their camels; in return, they are supplied with provisions and water during the journey.

The Moors always lay out the profits of their journeys in the purchase of camels, and none of them travel to Timbuctoo without possessing at least one. The camels do not advance in files, as they would do in our roads lined by hedges and cultivated lands. On the contrary they move in all directions, in groupes, or single, but in this journey their route is always between N.N.E. and N.N.W. Those which belong to one master keep together, and don ot mix with strange camels; and I have seen as many as fifty grouped 
together in this way. A camel's load is five hundred pounds, and the carriage from Timbuctoo to Tafilet costs ten or twelve gold mitkhals, * which are paid in advance.

The camels which convey merchandise of light weight, such as ostrich feathers, clothes, and stuffs in the piece, have their loads made up with slaves, water, and rice; for, the load being paid for according to its weight, the proprietors of the camels, if that weight were not completed, would gain nothing by the carriage of merchandise more cumbersome than heavy. When the caravan stops, the groupes of camels are kept at the distance of two hundred paces from each other, to obviate the confusion which would arise if they were suffered to mix together.

When the Moors return to their country, they do not carry back merely ostrich feathers and ivory; but they take also gold, some more, and some less. I saw some who had as much as the value of a hundred mitkhals. This gold is generally sent to the merchants of Tafilet by their correspondents at Timbuctoo, in return for the merchandise sent by the former, and sold on their account by the latter. During our halts in the deserts, I often saw the Moors weighing their gold in little scales similar to ours, which are made in Morocco. 'The gold which is conveyed by these travelling clerks of the desert is carefully rolled up in pieces of cloth, with a label, on which are written the weight of the metal and the name of the individual to whom it belongs.

When night set in, we took our usual supper, consisting of water, bread, butter, and honey. Several Moors, with whom we were not acquainted, came and asked us for a supper; they then invited the two Moors who were of

* The value of the gold mitkhal is about twelve francs, and the silver mitkhal about four. 
our party to share their mess of baked rice and butter. Though they knew that they had partaken of my provisions, yet they did not think proper to invite me, a proof, that notwithstanding all my efforts, there existed a feeling of distrust towards me. At sun-set a north breeze arose, which, though not very cool, was nevertheless very reviving, and enabled me to enjoy a little sleep.

About eleven at night we set out, still proceeding northward, and directing our course by the pole-star. The camels are so well acquainted with the desert that, as soon as they are loaded, they take, as if by instinct, the northern course. It would seem that they are guided by the recollection of the springs of water which are found in that direction. I really believe that a traveller, though alone, might safely trust himself to the guidance of his camel.

The night was hot and calm, and the clear sky was studded with stars. We had before us the great and the little wain which appeared very near the horizon. As I could not sleep, I amused myself by observing the courses of the stars; I saw in the east the remarkable groupe called the constellation of Orion; I watched it during nearly half its course, almost to our zenith. On the approach of day, the stars disappeared and seemed to sink into an ocean of sand.

The camels never accelerate their pace, which is naturally somewhat tardy. When they are in haste, they thrust forward their necks, the motion of which corresponds with that of their legs. They are led by men on foot, whose labour is so fatiguing, that it is necessary to relieve them every two hours.

The ground over which we travelled during the night appeared to me to be even more barren than that which we had passed on the preceding days. For whole hours in succession we did rot see a single blade of grass.

At eleven in the morning the heat became excessive, 
and we halted at a place where we found a few little banks of sand. A slave was sent to seek out a few bushes that might afford us shade, but no such thing was to be discovered. The reflection of the rays of the sun on the sand augmented the heat. It was impossible to stand barefoot on the sand without experiencing intolerable pain. The desert is here and there interspersed with a few hills, and we found at very distant intervals a little grass for the camels.

We had been the whole of the morning without drink, and as soon as our tents were pitched we slaked our thirst. Our water began to diminish in proportion as our thirst increased, therefore we did not cook any thing for supper, but merely drank a little dokhnou. About eleven at night we broke up our camp and proceeded northward: at seven in the morning we turned N.N.W.

At eleven o'clock on the Sth of May, the insupportable heat obliged us to halt on a spot as flat and barren as that at which we had stopped on the preceding day. We pitched our tents, and assembled beneath them. Some drink was distributed to us; and, as we had tasted none since five o'clock on the preceding evening, our thirst was very great. Though the water had received a bad taste from the leathern bag, it was nevertheless exceedingly grateful. I observed some ravens and vultures, the only inhabitants of these deserts. They subsist on the carcases of the camels that die and are left behind on the road. At half past six in the evening, after having refreshed ourselves with a glass of water and dokhnou, we proceeded on our journey. We travelled all night in a northerly direction. The camels, finding no pasture, went on without stopping.

About 8 o'clock on the morning of the 9th of May, we halted in a sandy plain, where we found a little grass for our poor camels. There we perceived at a distance the camels of el-Arawan.

In the morning, little before sun-rise, the Moors who 
accompanied me shewed me the spot where Major Laing was murdered. I there observed the site of a camp. I averted my eyes from this scene of horror, and secretly dropped a tear-the only tribute of regret I could render to the ill-fated traveller, to whose memory no monument will ever be reared on the spot where he perished.

Several Moors of our caravan, who had witnessed the fatal event, told me that the major had but little property with him when he was stopped by the chief of the Zawâts, and that he had offered five hundred piastres to a Moor to conduct him to Souyerah (Mogador). This the Moor refused to do, for what reason I was not informed, and I dared not inquire. They also spoke of the sextant, which I have mentioned above.

Having pitched our tents near some water, we could drink as much as we pleased. Rice was boiled for our dinner and we were somewhat indemnified for the privations we had undergone in the preceding days. At six in the evening we proceeded northwards over a very level sindy soil, on which were scattered a few solitary patches of vegetation. Though the sand has a tolerable consistency, yet not a tree was to be seen. Towards nine in the evening, we arrived at El-Arawan, another commercial entrepot. We encamped outside the city, and in the neighbourhood I observed several tents and camels, which I was told belonged to the caravan, waiting for the signal for departure. Our arrival was greeted by the howling of dogs, a circumstance which reminded me that $I$ had seen none of those animals at Timbuctoo.

Being unaccustomed to riding on camels, I found myself extremely fatigued by the journey. The moment we stopped, I spread my wrapper upon the sand, and fell into a profound sleep. I did not find the heat so oppressive as it had been on the preceding days. I was roused to partake of an excellent couscous brought from the city.

VOL II. 
On the morning of the 1oth of May my guide took me to his correspondent Kalif, to whom I had been recommended in a private letter from Sidi-Abdallahi-Chebir. I met with a favourable reception, and he lodged me in one of his houses, where he had some slaves and merchandise.

As soon as I was installed in my new dwelling, my guide, who had been very attentive to me on the journey, wished through my influence to get himself quartered upon Kalif; but I refused to make,any such proposal to my host, lest I should appear troublesome. Finding me obstinate on this point, he-asked me to lend him my cotton wrapper to wear while he paraded about the town to visit his acquaintance. I consented to this in order to get rid of him; but next day, I thought it prudent to make him return my wrapper. Another time he told me that he had been robbed of the wooden bowl, out of which he used to drink on the journey, and earnestly begged me to ask my host for one and give it hin. Wearied by all these demands and not knowing how to get rid of the troublesome fellow, I gave him a flat refusal; but that did not deter him from coming very often to partake of my repast of rice and couscous. This man was continually asking the slaves, whether they had any provisions or other articles to sell, a practise by which he and others like him often induced the poor creatures to plunder their masters.

My host sent me, about eleven o'clock in the morning, a plate of well flavoured rice and meat, and about eight in the evening a plate of couscous for my supper. The water for my drink was brackish and luke-warm.

On the 11th and following days, I inspected the town of El-Arawan. It is situated in a hollow, and surrounded by sandy hills, which extend to the west. The streets are wider than those of Timbuctoo, and equally clean. The houses, built in the same manner as at Timbuctoo, are much lower and less solid; for the sand here is not of so clayey a nature. 
The roofs are flat; instead of the small pieces of wood, which are used in the buildings at Timbuctoo, they here substitute the stalks of a bullrush which grows in the neighbourhood of the town. Thin rafters of ronnier wood support these reeds, which are slightly covered with sand. The magazines are very small. The houses are all of very frail construction, and their number may be five hundred, each containing about six inhabitants, including slaves. Before the doors is sprinkled a yellow kind of sand, which is found by digging to a certain depth.

El-Arawan, like Timbuctoo, possesses no resources of its own. It is the entrepot of the salt of Toudeyni, which is exported to Sansanding, on the banks of the Dhioliba. Its soil is even more barren than that of Timbuctoo. As far as the eye can reach, no trace of vegetation is to be perceived. The camels of the numerous caravans have to go a great distance for forage. Wood is so scarce, that nothing is burned but camel-dung, which is carefully collected by the slaves. This is the only fuel used even for cooking. The Moors collect their camels every six days, in order to take them to drink at the wells, which are in the environs of the town. These wells are about sixty paces deep. They employ a camel to draw up the bucket, which is made of hide. A pulley is also used. The water of these wells is brackish, warm, and very unwholesome. The springs are numerous. At the depth of four feet from the surface is found a grey sand mixed with a little clay of the same colour. This sand is tolerably firm. At the bottom of the pits there is a very white kind of earth, resembling chalk, of which $\mathbf{I}$ carried away a specimen. There are also some black and grey pebbles, and a small quantity of calcareous stones, of which the Moors make a brim round the wells. The place in which they are dug is flat, and surrounded by large hillocks of sand. I have often seen the Moors employed in watering their camels. They have a trough of tanned hide, which 
stands on three supports of twisted wood. For drawing up the water they use a rope made of straw, first damped and beaten and afterwards twisted. Though water when kept in the houses is always exposed to a current of air, it is invariably warm, and consequently very disagreeable for drinking.

Many Moors and negroes, impelled by curiosity, followed me in the streets. Some asked for snuff; in vain did I assure them that I had none, and never used any, they would not relinquish the attack, and they called me christian as the greatest insult they could offer me. Their vociferations were accompanied by threatening gestures. I began to fear that I should lose my temper, and that the affair might become serious. I hastened back to my lodging, into which my assailants followed me. An old Moor took pity on me, and reproached them for their behaviour, assuring them that $I$ was a Musulman and a stranger, and under the protection of Kalif, who would be indignant at my being ill treated. He finally succeeded in dispersing them.

I found a great difference between the inhabitants of this place and those of Timbuctoo, where I had been well received by the Moors. The people of El-Arawan,' on the other hand, looked upon me with suspicion. They could not believe, that after having passed my youth among the christians, I should voluntarily forsake their customs and resume those of my kindred. Fortunately for me, some old men more zealous, or credulous, than the rest, declared that God would support me in the way of salvation, since he had inspired me with so astonishing a resolution. They added in Arabic, "' Let us thank God, that he has returned among us."

These disagreeable occurrences induced me to appear more zealous than hitherto. I went regularly to the mosque, but, when I prostrated myself, like the disciples of the prophet, I offered up fervent prayers to God, thus endeavouring 
to atone for the painful sacrifice of my religion which I was outwardly compelled to make.

El-Arawan is not a place of such active trade as Timbuctoo, whence all provisions for the former place are brought, Sansanding, which is twenty-five days' journey to the west, being too far distant to afford supplies. I was told, indeed, by several Moors, that the journey occupied a month.

El-Arawan sends, as $I$ have before said, the salt of the mines of Toudeyni to Sansanding and Jamina, by caravans of Moorish merchants, who also carry tobacco, which is cultivated in Tafilet and Zawât.

'This town, though inhabited by the Moors of Zawât* and the different countries on the banks of the Mediterranean, has no market. I never saw so dull a place. In the interior of the town there are, as at Timbuctoo straw huts for the slaves.

Bousbéhey, of which I have already spoken, is two days' journey distant from El-Arawan, and the inhabitants of the latter place purchase cattle there, as in all parts of the interior of Africa there are no markets. Each family kills a bullock from time to time and cures the meat, by drying it in the sun. It is eaten with rice or couscous.

Though the great distance of Sansanding does not permit the inhabitants of El-Arawan to go thither for millet, they procure from that place more valuable articles, such as ivory, gold, slaves, wax, honey, the cloths of Soudan, and cured provisions. Rice is also transported thence in small quantities. Cowries, which are the current money of Soudan, do not pass at El-Arawan. There nothing circulates but gold and silver-neat pieces of the value of a mitkhal, in imitation of the money of Morocco. The gold mitkhal increases in value as you approach the coasts.

El-Arawan is the point for the arrival of the caravans from Tafilet, Cape Mogador, Drah, Tawât, and the cities

* It was the Moors of the tribe of Zawât, who assassinated Major Laing. 
of Aghdâmus and Tripoli. They bring merchandise of European manufacture, such as fire-arms, gunpowder, stuffs, and a few productions of their own countries, as tobacco, dates, \&c.

Kalif, who was one of the principal merchants of El-Arawan, was a native of Tawât, and he received from his country merchandise which he sent to the Dhioliba. The caravans which perform this journey are seven days without procuring water; after which they reach the banks of the river, which $I$ was informed is very wide at that part.

I supposed it to be the banks of the lake Débo. At a short distance from this place which is not inhabited, negro villages are met with as far as Sansanding.

In the rainy season, which occurs at the same time as at Timbuctoo, the inhabitants of El-Arawan are visited by the Touariks, who come and pitch their tents in the environs of the city, and collect the duties which they impose on traders. These duties are not so exorbitant as at Timbuctoo. The Touariks observe some moderation at ElArawan, on account of its distance from their country.

The inhabitants of the town are all fanatical Moors; they have numerous slaves, which they purchase at Sansanding, and, notwithstanding the natural brutality of the people, they treat their slaves kindly; they allow them plenty of food, consisting of sangleh, which is eaten with a sauce made of dried baobab leaves, boiled and seasoned with salt or allspice. They also clothe them well. If to the misery incidental to this wretched country were added the bad treatment which slaves experience in some parts of the desert, the poor creatures could not long survive.

An old Moor named Sidi-Boubacar is the chief of El-Arawan; he acts as judge in all the differences which arise among the inhabitants. At his death his son succeeds him. The Mahometan chief levies no duties on the people. He is himself a merchant and possesses considerable herds of camels. In the rainy season, when forage becomes 
more abundant, the inhabitants use camels' milk as an article of food.

On the 14th of May, a violent gale blew from the east, which unroofed several of the houses, and raised such a quantity of sand, that it was impossible to keep the doors open. The heat, though there was no sun, was stifling. The air was full of sand, which descended in the night. It would be impossible to express what I suffered during this storm. I was obliged to lie on the ground, with my head enveloped in a pagne, to protect myself from the burning sand, which entered through the chinks in the door. I experienced a continual thirst, and had nothing but warm and brackish water to quench it. This unwholesome drink caused a violent derangement of the stomach, and the heat, rising to a degree $I$ had never before felt, produced a dreadful head-ache.

The slaves, obliged sometimes to walk barefoot on the sand, complained of violent pain, which they were not able to bear long, but which soon compelled them to return home. The Moors stay within doors, keeping a piece of cloth constantly before their lips, to prevent the sand from getting into their mouths. I was unable to comprehend how the mere love of gain could induce these people to live for twelve or fifteen years in such a dreadful country.

The town of Walet, mentioned by Mungo Park, is ten days' journey W. N. W. of El-Arawan. Some Moors, whom I saw, told me, that no water is to be met with on the road, and that , this town carries on a great traficic in salt with Sansanding, Yamina, and Ségo. 'This last place is five days' journey to the south; salt, which is its principal article of trade is obtained from the mines of Waden,* situated in the great desert, fifteen or eighteen days' journey north of Walet. This salt is made up in cakes of the same dimensions as those of Toudeyni. The inhabitants keep a great many ca-

* The Hoden of the maps. 
mels, as well as a few goats and sheep. Walet is situated on a barren soil, not susceptible of cultivation, and the inhabitants buy corn in the Bambara country. I was told that this town is as large as Timbuctoo. I questioned some Moors respecting Tichit, but was unable to obtain any positive information on the subject.

During my stay at El-Arawan the same scorching east wind continually prevailed and obliged me to keep myself within doors, which vexed me not a little.

The caravans which were issembled at El-Arawan prepared to depart in a few days. I looked forward with pleasure to the happy moment when I was to leave this disagreeable country. My host, a zealous Musulman, laid in a supply of provisions for my journey. It was neither to his generosity nor his friendship for me that I owed this attention;-it was purely a sacrifice, which his piety prompted him to make in order to conciliate the favour of the prophet. The provisions consisted of a bag of rice weighing about fifty pounds, a bag of dokhnou of the same weight, and about ten pounds of butter. This was more than sufficient to last me two months. Wishing to make some acknowledgment for the attention of Kalif, I offered him some pieces of silver, a pair of scissors, and a small piece of cloth, the only one I had left. The good Musulman at first affected an unwillingness to accept my presents, saying that I was poor, and that probably the things would be useful to me, and that what he had done for me was solely with the view of serving God. He however put the silver in his pocket, and was apparently much pleased with that sort of money which is very uncommon in this country. He sent my provisions to the tent of Sidi-Aly, a Moor, with whom I was to go to Tafilet. This man, whom Sidi-Abdallahi-Chébir had recommended to me, had received on departing from Timbuctoo ten gold mitkhals (equal to 120 francs) for my expenses in the desert.

A Moor, who was settled at El-Arawan, and with whom 
I used frequently to converse, made me a present of a skin to enable me to increase my supply of water. He informed me that I should suffer much from thirst on the journey, and that for seven or eight days we should meet with no wells. The description he gave of crossing the desert at this season made me shudder. I thought I should certainly share the fate of the many unfortunate travellers who had perished there. However I rallied my courage, by dwelling on the hope of relating in my native country the result of my observations. I then no longer thought any difficulty insurmontable.

Sidi-Aly, whom I had not seen at Timbuctoo, and to whom Sidi-Abdallahi, my host, had strongly recommended me, gave me extraordinary proofs of his regard. He assured me that he would treat me as his son. He confirmed the report I had previously heard respecting the scarcity of water on the road, and stated that we should have to undergo great privations, but that I must not be disheartened, as he would take care of me, seeing that I was not like the rest, accustomed to the heat of the desert, and could not so well bear the excessive thirst, to which we should often be exposed. This person was looked upon by the Moors as a zealous Musulman. I was assured that he feared God, and that he would act towards me as he had promised. SidiAly always carried in his hand a rosary two feet and a half long, the beads of which were as large as nuts. He never failed, when he met any one in the streets, to cast his eyes piously on the ground, at the same time moving his lips, as if he were muttering a prayer. By this hypocrisy he imposed on me, as he did on others, and I believed that he was as good as he pretended to be; but I was cruelly deceived. Notwithstanding his feigned zeal for religion, the old hypocrite did not keep one of the promises he made me, as will be seen in the sequel.

We left El-Arawan on the 19th of May 1828, at six o'clock in the morning. Aly, my guide, had sent his son 
to carry my luggage to the place appointed for the rendezvous of the caravan. My host had invited me to share his repast; but as it was not cooked, I was obliged to set off without tasting anything but a little dokhnou and millet. He again recommended me to my guide, and took his leave of me after wishing me a prosperous journey. It was about half past seven, when the caravan began to move to the $\mathrm{N}$. E. I was concerned to see the poor slaves, whom I recognized as having been my companions from Jenné to El-Arawan, running through the sand to overtake the camels, which were in advance.

Our caravan was numerous : it consisted of fourteen hundred camels, laden with the various productions of the Soudan; as gold, slaves, ivory, gum, ostrich-feathers, and cloth in the piece and made into dresses. In leaving El-Arawan the road leads over a sandy country, with but few traces of vegetation. After proceeding six miles in this direction, we arrived at Mourat, a small village, containing five houses like those of El-Arawan, and built of sand bricks. At Mourat, the sons of Sidi-Boubacar, chief of El-Arawan, keep a school, where the children of the inhabitants of the town study the Koran. Mourat appeared to me even more gloomy than El-Arawan; the uniformity of the soil is broken only by a few plants, which are eaten by the camels, and which are buried beneath the sand; drifted by the east wind. On leaving Mourat, the traveller comes to some deep wells filled with brackish water. Here our caravan stopped and took a hearty draught, for we were now about to enter upon a part of the desert where we should find no water for the space of eight days. In the midst of these vast deserts, the wells of Mourat, surrounded by fourteen hundred camels, and by the four hundred men of our caravan, who were crowded round them, presented the moving picture of a populous town; it was a perfect tumult of men and beasts. On one side were cameis laden with ivory, gum, 
and bales of goods of all sorts; on the other, camels carrying on their backs negroes, men, women, and children, who were on their way to be sold at the Morocco market; and further on, men prostrate on the ground, invoking the prophet.

This spectacle touched and excited my feelings, and in imitation of the devout Musulmans, I fell on my knees; but it was to pray to the God of the Christians: with my eyes turned to the north, towards my country, my relations, and friends, I besought the Almighty to remove from my path the obstacles which had stopped so many other travellers; in the ardour of my wishes, I imagined that my prayer was granted, and that I should be the first European who had set out from the south of Africa, to cross this ocean of sand, and succeeded in the undertaking. The thought electrified me; and while a gloom hung on all other faces, mine was radiant with hope and joy. Full of these sentiments I hastened to mount my camel, and to penetrate fearlessly into the deserts which separate the fertile Soudan from the regions of northern Africa. I felt as if I was mounting the breach of an impregnable fort, and that it was incumbent upon me to sustain the honour of my nation, by divesting myself of every kind of fear and braving this new peril.

A boundless horizon was already expanded before us, and we could distinguish nothing but an immense plain of shining sand, and over it a burning sky. At this sight the camels uttered long moans, the slaves became sullen and silent, and, with their eyes turned towards heaven, they appeared to be tortured with regret for the loss of their country, and with the recollection of the verdant plains from which avarice and cruelty had snatched them. 


\section{H A P T E R XXI I I.}

Violence of the east winds.-Pillars of sand.-Scarcity of water.-Deplorable situation of the caravan.-Hills of loose sand.--Rocks of granite.-Wells of Telig.-Toudeyni, rich salt mines.-Thistle of the desert.-Vexations and persecutions of the Moors, their intolerance.Wells of Cramès.-Well of Trasas or Trarzas.-Trajacant Moors.-

We continued our route to the north a little west, through a district uniformly arid, interspersed with little sand-hills, in a direction from east to west. The east wind had now subsided, and the heat was excessive on account of the calm. We were tormented with thirst, for we only drank once in the course of the day. I derived some benefit from the care I took, after the example of the Moors, to fasten a strip of cotton cloth over my eyes, and another over my mouth to keep off the burning air which parched my lungs.

In the course of the day, we had passed over grey and red gravel in many places. Towards half past five we halted on unvaried sand; and a large calabash of water mixed with dokhnou was brought to us. We had eaten nothing all day, and yet we felt no need of food; for the dokhnou is very nourishing, and the burning thirst with which we were tormented had taken away every thing like hunger. A Moor was sent to take care of the camels, which were wandering here and there in search of a few blades of grass.

About ten at night, we had some rice cooked, which we ate with melted butter; but it made me very thirsty. I begged for a little water; but old Aly, my guide, who had remained behind, no doubt that he might drink as much as he liked himself without being seen, came up at the moment they were preparing to give me the water, and 
peremptorily countermanded it. This was only a prelude to the annoyance he afterwards caused me.

On the 2oth of May, at five in the morning, we continued our course to the north, the country being of the same nature, as that which we traversed the day before. About ten o'clock we halted in a place which was absolutely bare. The heat was beginning to be excessive, and we hastened to stretch the covering (a tanned sheep-skin which served for a tent) under which we collected for the rest of the day. We had each a calabash of water containing about three bottles which we swallowed at a draught; but this tepid water only filled the stomach without quenching our thirst: I would fain have drunk oftener, and a smaller quantity at a time, but the Moors who presided over the distribution of the water would not hear of this new arrangement, and adhered to the old practice.

The poor negro slaves, accustomed to a fertile country, suffered from this way of life, but they were no worse off than the rest of us; we were all on an equality.

It was not yet noon, and we were to have nothing to eat or drink till five in the evening. The heat was excessive and the east wind raised a great quantity of sand, as it had done most days; we suffered dreadfully. At the moment when I was thinking of nothing but the present calamity, old Aly came to inform me that the water-skins which Sidi-Abdallahi of Timbuctoo had given me were not large enough, and that our provision of water would not last long if we were not extremely economical. 'The rogue was right; for whilst I had three skins for my share, he and his compa$\mathrm{n}$ io had only two small ones a-piece, and there were nine persons to be supplied for a week. I was certainly entitled to forbid their making use of my stock; but what should I have been the better if $I$ had ? they would have drunk the water, and told me the east wind had dried it up. I answered therefore that I was obliged to Aly for his informa- 
tion, and that 1 should take his advice. During this conversation, which was followed up on my part by many painful reflections, the east wind increased; it was no longer a time for talking of one's affairs, but every one lay down to sleep, as we intended to travel during the night. My eyes never closed, and I lay wide awake. The east wind continued till sunset and then changed to the west; though its force was abated, it hardly incommoded us less, for it still blew up a great quantity of sand.

At five o'clock we had a calabash of dokhnou, and then lay down again till nine, when we started. We marched all night; and the calm was stifling, for the west wind had ceased. The country through which we travelled was quite level and absolutely barren. The slow and unvaried step of the camel made me drowsy. I laid my head upon my bag, and slept a little.

On the 21st, at ten o'clock in the morning, we halted. The burning east wind which was beginning to blow rendered the heat insufferable, and the scorching sand found its way into our eyes, in spite of the precautions which we took to exclude it. We pitched our tents, and tepid water was distributed, which we thought delicious though it had little effect in quenching our thirst; after we had drunk it, we stretched ourselves on the sand to repose. Notwithstanding all the precautions I had taken, the heat was so intense and my thirst so tormenting, that I found it impossible to get any sleep; my throat was on fire and my tongue clave to the roof of my mouth. I lay as if expiring on the sand, waiting with the greatest impatience for the moment when we were to have our next supply of water; I thought of nothing but water-rivers, streams, rivulets, were the only ideas that presented themselves to my mind during this burning fever; in my impatience I cursed my companions, the country, the camels, and for anything I know the sun himself, who did not make sufficient speed to reach the horizon. 
The spot where we were encamped was frightfully arid, there was not a single leaf to refresh the eye, and nature presented her most terrific aspect.

The camels scattered over the plain, the profound solitude, the silence of the desert, produced painful impressions, which it is difficult to describe ; the poor animals, exhausted with fatigue, were lying near the tents, with their heads between their legs, quietly waiting for the signal of departure; it was given at last. At half past four Sidi-Aly who had undertaken to provide our rations, threw a few handfuls of dokhnou into a large calabash, and poured water upon it; he then mixed the whole with his hands, thrusting his arms in up to the elbows-a sight which would have disgusted any one less hungry than ourselves, for water was so precious that old Aly's hands had not been washed for many days. 'Though the beverage was luke-warm, and very dirty, we drank heartily of it, and with the greatest delight.

When the Moors had quenched their thirst, they went to look after the baggage, and to see that none of the straps had given way. In spite of this examination, which is repeated at every halting-place, the camels are often galled by their loads, and these hurts are not easily healed; the Moors apply fire to the wounds, and often scarify the neighbouring parts and the tumours themselves, to let out the blood and matter; they cut away the dead flesh, and cover the wound with salt to prevent mortification. When a camel is ill, or ready to die of exhaustion, the Moors give it a little water, and for this purpose they use a wooden funnel which they apply to its nostrils; this is the best method of watering a camel, because the animal, though naturally docile, shakes its head about and spills the water on all sides, when it is applied to its mouth. It is only in cases of extremity however that they have recourse to this practice.

Sometimes it was immediately after doctoring the wounds 
of his camels that Sidi-Aly came and mixed our beverage without washing his hands; if by chance he did wash them, he gave the water he had used for this purpose to his poor slave to drink! I cannot describe the horror and disgust which I felt at this man's contempt for his fellow-creatures.

At five o'clock in the afternoon, we pursued our course towards the north; at ten we stopped for prayer, and having discharged this pious duty, we received a ration of water, very insufficient however to quench our thirst; for the further we advanced into the desert, the more intense became the heat. In the night I was almost consumed with thirst; but I could get no water. I doubled myself up upon my camel, whose motion lulled me and made me feel drowsy, but I could get no sleep.

On the 22d of May, at nine in the morning, the caravan halted; we were all exhausted by thirst; the east wind was hotter than ever, and our water was rapidly diminishing, for the wind caused a great evaporation by drying the skins; and a great deal of water filtered through the pores. As I lay on the sand, I ruminated on the possibility of alleviating the horrors of our condition; I desired Sidi-Aly to buy two or three more slins if any could be found, and I gave him for this purpose some goods which I had received from the Moors of Timbuctoo. He replied that nobody would sell them at any price; which I believed, but I suffered too much not to insist upon making the experiment. He then proposed to send one of the men belonging to the caravans to the nearest wells which he said was the best way of getting water to make sangleh to recruit our exhausted strength. I thought this a good plan, and agreed to it with pleasure; but Sidi-Aly, who was not the most scrupulous of Musulmans, never made the least inquiry for such a person; he took into his own possession what I had given him to pay the messenger, and sent his son to the well. 'This he would have done 
whether I had paid or not, for as I afterwards found it was the custom to do so, and I saw the Moors set off from all parts of the caravan for the same purpose.

My thirst was so intense that I determined, in order to appease it, to go into the neighbouring tents, and see if I could obtain a few drops of water out of charity. With my rosary in my hand, I went from tent to tent, to beg a little water "for the love of God;" I did not find many charitable souls, but it was not a favourable moment for the experiment, for we were all suffering alike. My useless fatigue, and the impatience it occasioned, augmented my torments, and when I got back to my tent, I fell on the ground senseless. 'The Moors who are themselves the most importunate beggars in the world, do not like to be asked for any thing. Sidi-Aly told me that I ought not to ask other people for water, that it was troublesome; I found out also that he boasted amongst his friends of the kindness he showed me, and said that he was grieved at the privation I endured. A lying hypocrite! he took no better care of me for that. Many of the Moors thought that he had brought me with him out of pure compassion, and, far from undeceiving them, he took care to confirm them in this error; but when they questioned me on the subject, I told them the state of the case, and they then assured me that I had paid too much to my guide. I knew that full well; but what could I do ? only resign myself to my fate.

About five o'clock in the afternoon, after having quenched our thirst, we continued our course to the north, and traversed a district interspersed with grey quartz rocks streaked with white : at midnight we ascended some sand-hills.

On the 23rd, at ten in the morning, we halted on sandy ground, but rather more solid than what we had crossed the day before, and interspersed with rocks of rose-coloured and black granite. Our situation was still the same; the east wind blew with violence; and far from affording us any re- 
freshment, it only threatened to bury us under the mountains of sand which it raised, and what was still more alarming, our water diminished rapidly from the extreme drought which it occasioned. Nobody suffered more intensely from thirst than the poor little slaves, who were crying for water. Exhausted by their sufferings and their lamentations, these unhappy creatures fell on the ground, and seemed to have no power to rise; but the Moors did not suffer them to continue there long when travelling. Insensible to the sufferings which childhood is so little fitted to support, these barbarians dragged them along with violence, beating them incessantly, till they had overtaken the camels, which were already at a distance.

Indeed, no person was privileged; even the Moors, whose turn it was to walk by the camels, and who, partly to amuse themselves and partly to encourage the animals, sang to them as they marched by their side, were under the same law as those who were riding, and never tasted water except when it was distributed to the whole caravan. I thought I could perceive nevertheless that Sidy-Aly had under his dress a small bottle, like our hunting bottles, and that the old fox made use of it every now and then in secret to refresh himself, without any regard for his brethren.

What distressed us most during this horrible day was the pillars of sand, which threatened every moment to bury us in their course. One of the largest of these pillars cros sed our camp, overset all the tents, and whirling us about like straws, threw us one upon another in the utmost confusion; we knew not where we were, and could distinguish nothing at the distance of a foot. The sand wrapped us in darkness like a thick fog, and heaven and earth seemed confounded and blended into one.

In this commotion of nature, the consternation was general ; nothing was heard on all sides but lamentation, and most of my companions recommended themselves to heaven, 
crying out with all their might, "There is no God but God, and Mahomet is his prophet!" Through these shouts and prayers, and the roaring of the wind, I could distinguish at intervals, the low plaintive moan of the camels, who were as much alarmed as their masters, and more to be pitied, as they had not tasted food for four days. Whilst this frightful tempest lasted, we remained stretched on the ground, motionless, dying of thirst, burned by the heat of the sand, and buffetted by the wind. We suffered nothing however from the sun, whose disk, almost concealed by the cloud of sand, appeared dim and shorn of its beams. We durst not use our water, for fear the wells should be dry, and I know not what would have become of us if, about three o'clock, the wind had not abated. As soon as it became calm, we prepared to set off, and the dokhnou was mixed and distributed. It is difficult to describe with what impatience we longed for this moment; to enhance the pleasure which I expected from my portion, I thrust my head into the vessel, and sucked up the water in long draughts. When I had drunk, I had an unpleasant sensation all over me, which was quickly succeeded by fresh thirst.

About half past four in the afternoon, we left the place where we had experienced this terrible hurricane, and proceeded on our way towards the north. 'The camels walked slowly and with effort, for they were almost exhausted; the poor beasts looked jaded and dejected. The sight of this numerous caravan, destitute of water, and condemned to die of thirst, scattered over the arid land, was truly dismal. The camels gently shaking their heads, or ruminating, took their course towards the north, without requiring any direc. tion. We advanced over a sandy soil covered with rocks, rising about five feet above its surface. Wrapped in my own reflections, I thought of the wisdom of divine Providence, which has anticipated all our wants. What a masterpiece of nature's workmanship, said I, is the camel! If it were not 
for this wonderful animal, who could exist for a week without food, how could these deserts be traversed? No mortal would dare attempt it, or if any were rash enough to venture upon such an undertaking, certain death would be the reward of his temerity. These reflections are trite; but they were natural in the situation in which I was placed, and I wish to give an account of my thoughts as well as of my sensations and sufferings.

On the 24th of May, at nine in the morning, we halted in as barren a spot as usual. The night had been calm, and the heat stifling; the fatigue we endured was augmented by the quantity of sand which fell upon us all the time we were travelling. We continued all day in a state of impatient expectation mingled with fear; the Moors, seeing our dejection and sufferings, tried to encourage us with the hope of the speedy arrival of the messengers who had been sent in search of water : vain hope! none of them returned. Despair was general; to keep up our spirits, a small quantity of water was distributed, and we were told that the delay of our messengers was not occasioned by their finding no water, but by their finding it in small quantities, so that it took longer to fill the skins; that they would have returned immediately if they had met with no water. Alas! this was a mistake, as will shortly appear. That we might not lose time in uncertain expectation, we continued our journey towards the north, at about four o'clock in the afternoon, over a firmer soil than we had lately crossed, and equally covered with quartz; we proceeded all night in silence; nobody slept however, for we were all too thirsty. The Moors who drove the camels were mute, and relieved one another oftener than usual.

On the 25th, at nine in the morning, we halted in a plain of hard sand, producing a few herbs, which were speedily devoured by the camels. This plain was interspersed with hills of coarse red sand mixed with gravel. We 
had now only a skin and a half of water remaining for eleven persons, we had indeed more than that number with us, and the allowance was every time more and more scanty; we suffered beyond all expression. After drinking a few drops, we lay down to wait for those who were gone in search of a fresh supply. About ten in the morning the poor wretches arrived half dead with thirst, and as soon as they had been relieved, as far as our small store permitted, they told us that they had had great difficulty at first in finding the well; and that when they had reached it they were dreadfully disappointed to find it quite dry; they were by this time so tortured with thirst, that they resolved to kill a camel, that they might divide amongst them the water contained in its stomach! a poor resource, for the water was not pure, and there was very little of it. The blood of the animal would have been a great refreshment, but they durst not drink it for fear of infringing the laws of the Koran.

About four in the afternoon, after having drunk the rest of our water, we were again on our way, more thirsty than ever, and proceeding slowly towards the north, in the hope of reaching the wells of Telig by the morning of the 26th. At nine in the evening we stopped for prayer as usual; a Moor who accompanied us gave us each a little water, which we received most gratefully; it relieved us very much. The night was very hot like the preceding. About ten we turned for three miles to the east, along the foot of some high hills of moving sand.

On the 26th, at five in the morning, we passed near some large masses of white earth, which looked at a distance like houses in ruins; in this part is found a very fine grey sand. The camels, though laden, lay down to roll themselves, which raised a terrible dust; and the Moors had infinite difficulty in preventing them from doing so. I also observed in this place gravel of the same colour, and further on $I$ found veins of white earth, of the same nature as the masses already 
mentioned. About three miles to the west we saw some sand-hills, covered with granite, the colour of wine-lees ; it is very brittle, and appears to lie in strata three or four feet thick.

We travelled the whole morning in an extensive plain, enclosed by these hills; the soil was very hard, covered with rocks and red and black granite, in flaky strata like slate. About eight in the morning, after climbing a high hill, we descended into a sort of basin formed by hills of red granite; the chain extends from east to west; the highest point that we passed over was three or four hundred feet high. In this valley, the soil of which is composed of coarse yellow sand, are the wells of Telig. We found these much wished-for wells filled with sand; which the Moors immediately fell to work to clear out; the poor camels which had already become unmanageable, from knowing that they were near water, were then permitted to drink: when they were driven away by the whip, they ran off to a little distance, and came crowding again round the well, ruminating, and laying their heads on the damp sand which had been thrown out of it. The first water we drew up was very black and muddy; but, in spite of the sand which it contained, the camels fought for it with fury. These wells, which afford plenty of brackish water, are not more than three or four feet deep.

When the water was fit to drink, I went and thrust my head in amongst the camels to drink with them; a Moor permitted me to drink out of his leather bucket, for we had not stopped to unpack calabashes, which were our usual drinking vessels. To the east of these wells, where the ground is lowest, we saw the ruins of some houses built of bricks of white clay; they are almost buried in the sand which the wind drives over them : further on in the same direction, there is a great deal of white-veined earth like that with which these houses were constructed; it bears some resemblance to lime. 
The whole day was employed in watering the camels, who seemed as if they would never be satisfied, and quarrelled for the last drop in the trough. I was forced to remain in the sun, for the Moors were so busy with their camels, that they never thought of pitching a tent. The east wind, which blew violently, rendered the day very unpleasant, particularly by the clouds of dust which it threw over us. As water was now abundant, we had a little rice cooked, which we ate with butter; it was the first meal we had taken since the evening of the 19th.

On the $2 \%$ th, many of our companions went to Toudeyni, which, as far as I could learn from our travellers, is a little less than half a day's journey to the west of the wells of Telig. From this little town is procured the salt which is brought from Timbuctoo to Jenné, and thence dispersed through all the Soudan. The salt mines, as I was informed, are three feet and a half or four feet below the surface of the ground; the salt is in thick strata, and is brought out in blocks, after which it is split into cakes of the size I have already described. These mines are the wealth of the country; they are worked by negro slaves, superintended by Moors, who live entirely upon rice and millet, brought from Timbuctoo, and cooked with camels' flesh dried in the sun. The water which they drink filters through the salt, and is extremely brackish; to render it more palatable they put dokhnou and honey into it; and they also improve this detestable beverage by mixing with it a sort of cheese reduced to powder, which I have mentioned above, and which is nothing but curd dried in the sun.

On the $2 \%$ th, about three in the evening, after having filled our skins with water, we broke up our camp, and iourneyed to the N. W. hoping we might meet with some vegetation for the poor camels, which wanted food the more, for having quenched their thirst. About five in the afternoon, we halted on a tract of loose sand, of a grey colour, 
where we found a few scattered patches of grass, which the camels devoured with eagerness, harsh as it was, as they had not eaten scarcely any thing for a week.

Just before we left the wells of Telig, we had been forced to kill two of these animals, which could go no further, and were dying of fatigue; the flesh was distributed among all who wished for it, and we had some for our supper. Part of it was boiled, and the rice which was cooked with it contracted the odious taste of the camels' flesh, which I disliked extremely. The Moors ate this meat with the greatest avidity, and said that it was excellent, but I was not at all of their opinion, for I thought it very tough, and the little $I$ ate disagreed with me; this might however be owing in part to the brackish water I had drunk. This was nevertheless one of the most comfortable nights I had passed since I had been in the desert; I lay down by a patch of grass, and the heat seemed to me less overwhelming than on the preceding days, which $\mathbf{I}$ ascribed to the vicinity of the wells.

The soil was covered with grey quartz, striped with a dirty white, mixed with which were several kinds of small gravel.

On the 28th at sun-rise, we were on our way in a northwesterly direction amongst quartz rocks; here and there upon the ruins of sand grew a few withered herbs which the camels browsed as they passed. About ten we crossed a soil covered with small black gravel, and varied by sandhills extending from east to west; this sand was harder and yellower than what we had seen the day before; in some places we found grey gravel and several rocks of black and grey granite. At half past ten we halted to rest our camels, which were all very weary, and they were fortunate enough to find a few thorny plants * which they amused themselves 
with cropping. These plants have short and flexible leaves; the thorn is short but very hard; by the wise providence of Nature this plant, the only resource of the animals of the desert, has the property of remaining green all the year round, in spite of the burning east winds which so frequently prevail; the camels though not very delicate would refuse the dry leaves. This plant is very tenacious of life, throws out long roots on the surface of the ground, and does not grow to the height of more than eighteen inches; it is found in sandy places, and $I$ have generally observed that it is most abundant on the west side of the hills. The roots are thick and serve for fuel; the Moors use it to cook their provisions, and at sun-set the slaves went to collect it, to boil our scanty portion of rice with water and salt, to which they added melted butter for sauce; this was our frugal supper. My portion was set apart for me in a little calabash: for the Moors did not chuse to eat with me after they had discovered that I had had the scurvy; they held me in utter abhorrence. In spite of the pains which I took to study their habits and customs, they observed that I could never eat rice as they did, making it into a little ball in the hand and tossing it into the mouth; when they meant to insult me, therefore, they always told me that $I$ ate like a christian.

Sidi-Aly, my guide, was a short man, about four feet high, with a wrinkled face, black mischievous-looking eyes, a little grey beard, a rather long chin, and a large mouth, which rendered him still more hideous: this man ate by himself that he might appear to be a person of importance. Thrusting his dirty hands, the chapped skin of which resembled a crocodile's scales, into a leather bottle, to take out some butter to put into our rice, he stirred our victuals about in this cleanly manner. Notwithstanding all the fine promises of protection which he had made me at first, I soon found how little he was to be trusted. He refused me the 
necessaries of life, and especially water, although he had been handsomely paid beforehand; the slaves were better off, for he did not prevent them from helping themselves when they wished-thanks to the wells at Telig however, there was no longer a scarcity. Fortunately the heat did not appear to me so great, nor was my thirst so tormenting as heretofore; whether because we were in the neighbourhood of water, or because we were now advancing to the north, I know not; whatever was the cause, I enjoyed some alleviation of my sufferings : a mortification, however, but of a different nature was in store for me.

The Moors of Aly's party, seeing that he had ceased to behave respectfully to me, were no longer under any restraint; they gave me ridiculous nicknames, calling me Gageba, from the name of the camel I rode on, and I was constantly exposed to their insult and raillery. Encouraged by my silence and patience, they set their slaves to follow their example, and the slaves were delighted to torment me; they talked on no other subject; they were continually ridiculing the form of my face; and they carried their ill-nature so far as to throw stones at me when I turned my back. All this persecution was at the instigation of their masters, who often supplied them with branches of thorns to thrust into my face; at other times they took little pieces of wood, and proposed that the slaves should drive them through my nose, as they do to the camels. These slaves, encouraged by the visible satisfaction of their masters, collected around me, laughing violently, capering, dancing, and showing me first the branch of thorns and then the piece of wood which they had been ordered to run through my nose. In this way I was tormented all the way from Telig to Tafilet. The Moors would often say with contempt, "Look at this slave; I would rather have him than thee, so thou mayst think how little I value thee." This insolence was accompanied by immoderate laughter. When I was eating, these boors 
would come about me opening their mouths as wide as they could; then, with hideous grimaces they thrust their fingers into them to mimic me, and called out at last: " $\mathrm{He}$ is like a christian!"”

I swallowed my vexation, trembling at the thought of what such men would do to me, if they discovered my real sentiments; they would have made a martyr of me; and I could not but think of the tortures which poor Major Laing must have suffered from beings who were still more ferocious. How I longed for the moment when I should reach Tafilet, and get rid of my tormentors. I had absolutely nothing left but the clothes $I$ had on, and a new coussabe which I owed to the generosity of my Timbuctoo host, besides a padlock which secured the bag that contained my notes: not a day passed that these did not excite the cupidity of my companions; when $I$ asked for water they said: "Give us thy new dress and thy padlock, and thou shalt have something to drink." They purposely left me in want that I might give them what they wished; but I had courage to resist and they obtained nothing.

The wells were now nearer together, and as we came to them more frequently, we could travel part of the day. When the heat was excessive, during the journey, those who wanted to drink were allowed to have water; on these occasions they pointed at me and said to one another: "Do not let us give him any, till he has promised us something." I disdained to have recourse to entreaty, and bore both hunger and thirst rather than ask for any thing at their hands; so I turned my head away, and pretended not to hear what they said. Thirst at last compelled me to apply to Sidi-Aly, who muttered when he ordered them to give me water; while I was drinking it he imitated the humming noise made to induce the camels to drink. He durst not refuse me the water for his own sale; for the other Moors in the caravan, who were not his associates, would have 
been indignant; in their presence he always pretended great kindness for me, and compassion for the sufferings which I had endured in the desert. It was impossible that he could altogether deceive them, for, notwithstanding the abundance of water which we had since we left Telig, I was often obliged to apply to the other Moors in the caravan when I wanted drink: I was also driven out of our tent many times by the rudeness of my tormentors, and took shelter with my neighbours, who were much amused with my conversation, and collected around me, to question me about my escape from the christians, their manners and customs; they asked me also whether I had been ill-treated by my white master. I always took care, as much as I could, to counteract the impression which they all have, that Musulmans are ill-treated amongst us, an idea which proceeds from their intolerant system.

They all showed me their guns and inquired where they were made; and when I told them that they came from France, I observed that they thought them the more valuable : accordingly, if I wanted to flatter a Moor I told him that his gun was of French manufacture, and out of gratitude for the pleasure which I afforded him, he commonly offered me a share of his dokhnou and water.

On the 29th, at six in the morning, we proceeded northward. The soil over which we passed was covered with quartz. About nine o'clock in the morning, we halted in a place where we found some traces of vegetation amidst the rocks. One of the Moors took water in his leather bag, and went to tend the camels; the others were engaged in examining and weighing their gold; they commonly hide it as I have already mentioned, in pieces of rag, on which they put a mark denoting the quantity, and the person to whom it belongs; for this gold is often the proceeds of goods entrusted to them by merchants, when they leave Tafilet.

The camel upon which I rode was laden with ostrich- 
feathers only. That it might be the less fatigued with the journey, I was never allowed to mount it while it was on its knees; one of the Moors was commissioned by SidiAly to help me to mount; and, for the reasons above stated, this Moor was very ill-natured, and took every opportunity of playing me a trick which might raise a laugh amongst his companions at my expense. At nightfall, rice was cooked for our supper. We had nothing before that but a little dokhnou and water to refresh us; as the roots of this plant were scarce, the slaves were sent to pick up camel's dung for fuel; though the wind quickly effaces their footsteps, it is always easy to track them by the great quantity of their excrement.

At ten in the evening, we broke up, and proceeded towards the N. W. The soil, which was as unvaried as ever, was covered on the surface by quartz. The night was calm, and the heat stifling.

On the 3oth of May, we halted at eleven in the morning, and found some herbage, which supplied the camels with food during that day and part of the succeeding night.

On the 31 st, at two in the morning, we continued our journey in the same direction. The soil was sandy, and covered with hills of loose yellow sand. In crossing the desert, I perceived, at a distance, immense tracts, which had the appearance of rivers or lakes, with islands of sand rising in the midst of them; they presented themselves to the eye, in the horizon of the desert, as places where one might quench one's thirst. This prospect broke for a time the uniformity of these vast deserts; on approaching, I was cruelly disappointed, for the water vanished, and I saw nothing but loose saud where I had hoped to quench my thirst. This illusion only rendered my situation more dreadful, when I was consumed with thirst, and saw the sea receding before me as by enchantment. It is impossible to form any correct idea of a mirage without having seen one. 
Towards noon we halted; the burning heat was augmented by a scorching wind from the east. My thirst was excessive, but I had no means of quenching it; my companions told me, to comfort me, that we should soon come to wells. In fact, the wells of Cramès are in this part of the desert; and we hoped to find water there; but alas! they were dry. These wells are situated near a chain of hills extending from N. N. W. towards south. At intervals, we came to a few tufts of herbage; the only trace of vegetation which is to be found here.

We pitched our tents, and sheltered ourselves under them from the burning wind; we had a very short allowance of water dealt out to us, on account of the impossibility of procuring more. The soil in this part is composed of hard sand, mingled with gravel; the east wind blew with such violence, that all our tents were overturned. About suriset, we had an alarm; the camel-drivers at a distance from the camp, saw some Moors, whom they took for banditti; they came to us, calling out, "To arms! to arms!" The whole camp was immediately on the alert; every one flew to arms, and hastened to meet the supposed enemy. I saw some of our party tremble, which made me presume that the danger was great. No person was left in the camp besides three or four old marabouts, the slaves and myself; they fell forthwith to prayers, and gave me a little water and a piece of camel's flesh, I suppose to propitiate Heaven. For my part, I was not less uneasy than the Moors ; I speculated sorrowfully upon what would be our lot, if we lost our camels, our only resource in the desert. We shall die in this horrid country, thought I, for we are too distant to receive help from any quarter; and as a climax to misfortunes, our provision of water is exhausted. In fact, a few of the camels had returned, but the greater number were grazing out of the camp. In the course of an hour, I beheld, to my great satisfaction, our intrepid warriors re- 
turning; and they informed us, with an air of triumph, that the robbers had disappeared. All the evening the camp was in a tumult; and there was a long deliberation what was to be done for want of water. It was an object to set off at night to avoid the heat of the day; but our prudent companions were afraid of being attacked on their way; it was even suggested, that the robbers might have taken possession of the wells, at which we were to arrive the next day. Sentinels were appointed, and a watch was kept for a mile round the camp.

On the 1st of June, at five in the morning, we prepared to continue our course to the north. Our water-bags were now dry, for we had supplied our last night's sentinels with water. All the forenoon we were travelling over a barren soil, which was dreary to look at; it was composed of very hard sand, covered with much grey gravel, and small, flat, sharp-edged, black stones. I perceived, which was rather unusual, a number of small tracks of former caravans, and which the winds had not had the power to efface, because the soil is hard and stony.

I shall here relate a conversation which passed in my presence between Sidi-Molut, a Trajacant Moor, and SidiBody, associates of Sidi-Aly, my guide, and some of my greatest tormentors; the conversation turned upon the number of slaves they supposed the Europeans to possessjust as they suppose that all the christians, of whom they know nothing but the names, are of one nation and subject to one chief. In this persuasion, Sidi-Molut related that the sultan of Morocco had made an agreement with the sultan of the christians for the exchange of prisoners of both sexes; and that, by this treaty, a christian was to be exchanged for ten Musulmans, or a thousand piastres. The moment Body heard that the price of a christian slave was fixed at this sum, he interrupted Sidi-Molut, and said : "Well, we must 
sell Sidi-Abdallahi," pointing at me with his finger. The other replied that I was not a christian but a Musulman, and that a Musulman was worth all the gold in the world. I could not refrain from darting a look of contempt at Body; and I even told him I saw plainly, that if he could he would sell me, the sooner the better, without any respect for his religion. He did not seem to pay attention to what I said; but Molut looked at me with a smile and said: "Body is a rogue, is not he Abdallahi ?"

The soil over which we travelled in the afternoon was covered with hills of loose yellow sand; we saw some vegetables, but at long intervals; the heat was excessive, and again increased the pangs of thirst. At last, about two in the afternoon, we halted near the wells of Trasas or Trarzas, situated in a plain surrounded by hills of yellow sand. These wells, which are numerous, are seven or eight feet deep; the water is salt and most disagreeable.

Here we found some Trajacant Moors, the very people whom we had descried the day before, and who had alarmed us so much; we had occasioned them equal alarm, and it was for this reason that they had not halted at the wells of Cramès. The wells of Trasas were filled with sand, but the Trajacants had cleared out two of them. In this plain, the surface of which is composed of hard grey sand, we found some lumps of salt, and near the place where we watered our beasts, several houses built with bricks of this substance. The Moors informed me, that there was formerly a large village in this place, belonging to their tribe, and that the inhabitants used to work the Trasa salt mines, and carried on considerable commerce in this article with the Soudan. They had many camels, as I learnt from the same authority; but the village had been destroyed by the Tafilet Moors. It is, nevertheless, very probable, that this village was voluntarily abandoned by the inhabitants, who might be dis- 
couraged by the great difficulty of finding fodder for their beasts, and grain for themselves, and also by the annoyance of being always forced to drink salt water.

As the Trajacants had taken the trouble to clear the wells, we had nothing to do but to profit by their labour; and to reward them, Sidi-Aly and Sidi-Molut joined to give them a good supper.

As our tent was not pitched, I took shelter under that of the Trajacants. I found them drinking dokhnou, and talking over the adventures of their journey; the moment they saw me, they perceived that I was not an African; their first look announced their ill-will, and one of them asked me who I was. A Moor of our caravan who happened to be with me, spared me the trouble of answering; he took the affair into his own hands, and related, without any omission, the fiction which I had industriously circulated, and which was now received as truth amongst all those who knew me. They afterwards criticised my countenance, which did not seem to them to possess the genuine Arab character, though I was by this time exceedingly dark; but my complaint had entirely disfigured me. The Trajacants asked me many questions about the Christians, and made me repeat a verse of the Koran which 1 had learnt by heart; they afterwards drank by turns, and then poured salt water upon what was left in the vessel, and asked me to drink.

On the $2 \mathrm{~d}$ in the morning, Aly sent two of his Moors to look out for fodder; they went a great distance, and returned in the evening with two little bundles of straw, which were given to the animals, and immediately devoured. Sidi-Aly asked me to go to seek food for my camel; I replied that he might go himself, and $I$ went to the tent of two Wadnoun marabouts. These men were very kind, and censured SidiAly's conduct towards me without reserve. All this day was employed in watering the beasts, and in laying in a stock of water for ourselves. The salt water penetrated our skins and 
ran out at the seams, in spite of all we could do. Some of the Trajacants set off before us.

On the 3rd, at five in the morning, we proceeded to the N. W . first crossing a chain of hills, and then travelling over a soil composed of black gravel, with flat, sharp-edged stones. We halted about half past eleven in a plain, in which were a few thorny plants for the camels to feed on. As we had plenty of water, we boiled a little rice with some morsels of camel's flesh, which had been dried in the sun, and were as hard as leather. After this savoury repast, we lay down on the ground by our baggage, to rest.

On the 4 th, at two in the morning, we prepared for departure, and directed our course N. N. W. till towards eleven; we travelled at first over very hard sand, and then crossed a chain of hills stretching from E. to W. About two in the afternoon, we halted, very much fatigued, because we had had to ascend the hills of loose sand amongst which we had encamped over night. I have observed that fodder is more abundant in these hilly tracts than it is elsewhere. I looked in vain for shells on these mountains; a search which was suggested by the idea that the sea may formerly have covered the site of these immense deserts. 


\section{CHAPTER XXIV.}

Wells of Amoul-Gragim.-Enormous serpents.-High sand-hills called Helk.-Wells of Amoul-Taf.-Hills of various-coloured granite.Wells of el-Ekseif; very good water.-Wells called Marabouty, elGuedea, Mayara, and Sibicia.-High and steep mountains, defiles and precipices.-A severe fall.-Encampment of Sidi-Aly.-El-Harib.The Berbers - Tatta.Description of the country of el-Harib, customs; the tribes who inhabit it.

ON the 5th of June, at three o'clock in the morning, we continued to ascend lofty downs of loose sand; our direction was northerly: the western side of these downs was covered with thorny plants, which served the camels for food. The poor animals moved with so much difficulty, that our progress was slow and painful; we advanced but a mile an hour.

Towards noon, having climbed to a great elevation, we found ourselves on an extensive plain of very hard grey sand: we halted near the wells of Amoul-Gragim; which, like the preceding, were filled up; these are only seven or eight feet deep ; their water is muddy and salt, but less disagreeable to the taste than that of Trasas.

This night seemed cooler than those which had preceded it: my rest was disturbed by the appearance of a serpent, which suddenly awoke me, and had nearly reached my head when I perceived it. I rose in haste; the reptile was alarmed by the noise I made, and returned immediately to its hole, which was not far distant : this serpent was five feet and a half long, and as thick as the thigh of a boy twelve years old. The idea of so unpleasant a neighbour banished sleep for the remainder of the night : my travelling compa- 
nions also experienced similar visits, and appeared no less dismayed by them than myself.

The whole of the 6th was employed in watering our camels ; we procured for then stalks of hedysarum-alhagi, and branches of the tamarisk, which grows on the plain at some distance from the wells: these were quickly de. voured. This night we lay down as on the preceding, and I was again annoyed with the sight of enormous serpents.

At four o'clock in the morning of the $;$ th, we directed our course to the N. N. E., among the chain of sand-hills called Helk; but these are not by much so high as those we had crossed the day before. Sidi-Aly, whom I questioned on the subject, and who at times vouchsafed an answer, assured me that in none of his former travels in the Soudan had he seen such lofty sand-hills; his route had always been more northerly.

As our road was better than that of the preceding day, we travelled at least two miles an hour. About half past eleven we halted at the foot of the chain, on a somewhat hilly plain of grey gravel, the finest I had yet seen.

On the sth, we set out at four in the morning, taking a northerly direction, over a sandy and tolerably level soil. Near noon we halted in a plain of firm ground, covered with sharp flints as flat as slate, and mixed with small gravel; this plain is surrounded by gently swelling downs. I longed to emerge from these frightful deserts, where the only indications of animated nature were the distressing east wind, and some light-footed antelopes, which swept across them with the rapidity of an arrow. I saw in several places skeletons of these animals, dried up by the burning sun; they had undoubtedly died of thirst.

On the 9th, at about one in the morning, we pursued our journey northwards; the soil was covered with black gravel, and studded with pointed rocks of the same colour. A little before eleven we halted at the wells of Amoul.Taf, 
situated among rocks of grey granite; it was necessary to open them; they are only four feet deep, the water sweet, but not plentiful; tamarisks flourish in the neighbourhood. We surrounded these wells with straw to prevent the sand from falling in.

The camels were but half watered, and we filled our leathern bags in preparation for departure.

At four o'clock in the morning of the loth, we continued our progress northward; and climbed a steep hill of granite with much difficulty, finding no beaten track. The soil we traversed was broken by hillocks of black gravel, and by sharp rocks : the country offered not the smallest sign of vegetation. Towards nine in the morning we descended into a plain, where we found a little grass, and some very stunted mimosa ferruginea.

Here we rested to let our camels graze, and killed one, which, quite overcome with the heat, could carry the baggage no longer : its flesh was distributed among:t the people of the caravan, and made us a very indifferent supper, but for want of better we were obliged to eat it.

On the 11 th we proceeded at four in the morning. If my inclinations had been consulted, the journey would have been delayed till sunrise, for $\mathbf{I}$ was much fatigued by rising every day so early. I was so sleepy that it was with much difficulty I could keep my seat upon my camel. I frequently called to mind that the only chance of surviving the journey lay in hastening our march; this idea supported my courage, and restored my exhausted strength: I confess nevertheless, that I envied the fate of those who can purchase fame at a cheaper rate than by such painful trials and continually recurring dangers.

We still travelled northward over a dry soil resembling that which we had traversed on the preceding day. As we advanced in this direction, the heat gradually diminished, and our thirst became less intolerable. About ten o'clock 
we halted; the tent was pitched, and I lay down in the hope of obtaining a little rest: next to thirst, the greatest torment I suffered arose from the fatiguing necessity of rising at all hours of the night, to pursue our journey.

On the 12th, at two in the morning, still half asleep, I mounted my camel and we resumed our route northward, over a level, hard and stony soil: I saw some mimosas scattered in the plain at great distances apart, without any other sign of vegetation. About nine, we descended, through a very narrow path, into a deep ravine, surrounded by enormous blocks of granite, of a pink and various other colours, in strata of eighteen or twenty inches thick. The camels, fatigued with so bad a road, had much difficulty in descending amongst these rocks. It was ten $\mathbf{A}$. M., when we halted at the wells of el-Ekseif, situated at the very bottom of the ravine. These wells, or springs, are shaded by a pretty grove of palm-trees of beautiful appearance; such at least is the impression produced by the contrast of this umbrageous and refreshing spot with the desolation that reigns around, and with the bare and arid region which we had just crossed; a few reeds and some rushes also grow round about.

This verdure, embosomed among immense rocks of granite, on a spot where, as far as the eye can reach, no other trace of vegetation is perceptible, has something at the same time wild and pleasing, which produces an effect strikingly picturesque.

The water of the wells of el-Ekseif is very good; I found a real luxury in drinking it, for it was sweet, bright, and limpid.

Tired of eating nothing but boiled rice, I went to a Moor who treated me with better fare. I recounted to him my privations, in which he seemed to take some interest, exhorting me to bear my misfortunes with patience, and inviting me to partake of his supper, which consisted of rice, boiled with meat dried in the sun, and seasoned with all- 
spice; the meat he had brought from Jenné, in which town he had lived several years occupied in commerce. I thought, by making him a little present, to obtain in return frequent invitations to his meals, and therefore gave him a piece of twenty sous, which he accepted; he considered himself however under no engagement in my favour, for he invited me no more.

On the 13th of June, we remained beside the wells to recover from our fatigues, and refresh ourselves with copious draughts of the delicious water. The soil on which we were encamped was dry, and full of stones, which we were ob. liged to clear away from the spot where the camels were to lie, lest they should be hurt. In the evening water was so abundant here that I was enabled to cool my body with a calabash of cold water, and I found great benefit from it.

On the 14th, we set out at five in the morning, still pursuing the same course. Descending into a plain where we found a little herbage, we halted about nine o'clock to allow the camels to graze. The road had been difficult and we had travelled about two miles an hour. At five in the evening, judging that the camels were satisfied, we continued our journey northwards, but had scarcely proeeeded a mile when we were obliged to wait for part of our company, who had stayed behind; the ground which we were upon was composed of very hard grey sand, covered with fine white gravel. Towards eleven at night, the stragglers, whom their beasts had carried to a distance in pursuit of food, arrived, and we resumed our route, guided by the pole-star; we travelled all night and till eleven in the morning of the 15th.

On the 15th, we met with the same soil as the day before, without any vegetation. A strong north wind prevailed and greatly incommoded us. At half past five P. M., after drinking some dokhnou, we again entered upon the desert. Travelling northwards all night, we found the air unusually cold, but free from fog.

On the 16 th of June, at sunrise, we saw a little chain of 
hills stretching from north to south; they appeared black, which made me presume that they were granite.

About ten in the morning, we rested at the foot of a chain of hills of loose sand, which ran in a parallel direction with the granite hills.

At two in the morning of the $1 \%$ th, we broke up our camp, and proceeded northwards; having on either side of the road hills of very fine sand. The poor camels cropped as they went along the heads of some prickly plants, the only species of vegetable which they could find. About ten we halted at the wells called Marabouty, situated a quarter of a mile east of our route, amongst high hills of moving sand : these wells, which are no deeper than the last, were also filled up, but we soon opened them.

I eagerly pressed forward to ask for drink, for I had not been able to obtain any on the road: my thirst was intense, and augmented by a violent westerly wind, which drifted the sand and rendered the journey most fatiguing. The neighbourhood of the wells is covered with the excrements of camels, to such a degree, that if the Moors were not well acquainted with their situation, these traces would sufice to point them out : the water is very good.

Another camel at the point of death was killed here and some of its flesh boiled for eating. Sidi-Aly had some pieces dried, and sprinkled with salt, to preserve them as a luxury for himself during the remainder of the journey.

On the 18th, at seven in the morning, we proceeded $\mathbf{N}$. N. E. at first amongst the sand-hills afterwards, over a plain of black gravel. About ten we halted to feed the camels, and a meal was prepared with part of the animal killed the day before. This mess did not provoke the appetite, but necessity taught us to eat it. One particular that I think worthy of remark is that my health continued perfectly good in the desert, notwithstanding the privations of every kind which I experienced. I had no fear of perishing but by thirst; and 
this was increased by the apprehension that we might lose our way and wander to a distance from the wells. Providence, however, watched for my preservation, and I escaped even this peril, the greatest, perhaps, which these frightful solitudes present.

At one o'clock in the morning of the 19th, we resumed our route over a hard soil covered with gravel, and followed the same course; some hills of little elevation were scattered over the country. At noon we arrived at a spot which offered a little grass, and there halted. A man was deputed to take care of the eattle, and we assembled under the tent for refreshment, and to shelter ourselves from the wind which now blew up clouds of dust.

On the 20th, at one in the morning, we resumed our journey northwards, over loose sand, and halted at ten; our camels found some prickly shrubs scattered over the plain. Towards midnight we broke up, and again travelled towards the north over some hillocks which rendered our progress slow and painful.

On the 21st, at nine A. M. we halted in the midst of sand-hills, amongst which grass grew pretty plentifully. We were a mile west of the wells of el-Guedea, where we found tolerably good water : the heat was greater than on the preceding days and it was increased by a dead calm : we were this day fully occupied in laying in a stock of water.

On the 22nd we recommenced our journey, still proceeding northwards; our progress was slow, as the camels browzed by the way on some thorny and half dried plants. The soil was of the same nature as that we had last traversed. At ten in the morning we halted to avoid the heat of the day, and about ten at night broke up our camp, directing our course northward amongst sandy hills till day-light, when we came to a more level soil covered with white gravel.

On the 23rd, at nine in the morning, we suspended our progress. Some pieces of camel's flesh dried in the sun 
were boiled for our dinner, but proved as hard as wood. The same evening at nine, we broke up, and, after proceeding northward for three hours, turned to the N. N. W. over a level soil, without any vegetation, and overspread with small gravel.

On the $24 \mathrm{th}$, at eleven in the morning, the heat being insufferable, we halted under our tent till it moderated, drinking a little dokhnou; and, about four in the afternoon, after having eaten some rice boiled with the flesh of the camel, we again advanced, bearing N. N. W. till sunset, when we turned northward to cross a chain of low sand-hills on which some grass grows. I learnt from my comrades that the Moors of el-Harib come as far as this place in the rainy seasons to pasture their flocks. We continued our journey till two in the morning, over a hard gravelly soil and some hills of loose sand; after which we halted till dawn, lying down beside our camels to rest. On each side of the place where we stopped were great rocks of granite, amongst which were seen some miserable plants of mimosa ferruginea.

On the 25 th, at four in the morning, there being sufficient light, we slowly advanced amidst large blocks of quartz, among which I saw many thorny plants and stunted mimosas, the bare branches of which the famished camels cropped and ate with avidity. Whether these animals were sensible that they were approaching their own country and the moment when their wants would be satisfied, I know not, but they appeared more sprightly and vigorous than usual. About ten o'clock the same morning, we halted at the wells of Mayara, situated in a defile surrounded by granite and some mimosas. The water of these wells, which are only four or five feet deep, is salt; its taste is detestable: we had still one leather bottle full of good water, but the Moors would not allow me my share of it ; they kept it all to themselves, and told me to go and drink with the camels. Three Moorish 
slaves, who were of our party, were more fortunate than I was; a small portion of the good water was given to them. At a hundred and fifty feet from the salt wells, there is another, the water of which is fit to drink, but it was nearly dry; several Moors passed part of the day in emptying it, and towards sunset I could quench my thirst at my ease.

On the 26th, I was awakened at one in the morning : we proceeded N. N. E. between two hills sixty or seventy fathoms in height, composed of great blocks of grey quartz and some granites of the same colour: many mimosas and hedysarum alhagi grow in this defile, the soil of which consists of grey sand. So long was it since I had seen any thing similar in point of vegetation, that $I$ thought myself in the most beautiful country in the world.

About eight in the morning, we entered a plain of black sand, in which we perceived here and there spots resembling little islands covered with herbage and mimosas. In proportion as we approached the limits of the desert, nature appeared less desolate. At eleven, we halted upon loose sand: we experienced the whole day a stifling heat, which created a dreadful thirst; as night drew on, some rice was boiled as usual for supper. About ten o'clock on the same day, we started towards the N. N. E, over a soil broken by deep ravines, on the edge of which some vegetation appeared. Our progress was slow, for the camels were allowed to graze as they went on; we proceeded but two miles an hour.

At nine in the morning of the 27 th, we stopped by the wells of Sibicia, situated between blocks of pale rose-coloured granite, and surrounded by a pleasant grove of datetrees, the verdure of which presented an agreeable contrast with the rest of the soil. The water of these wells, which are only seven or eight feet deep, is clear and delicious to drink.

About six in the evening, being occupied in prayer, we 
heard a musket-shot at a distance; this noise did not surprise us, as we knew that Sidi-Aly had gone on before from el-Guedea, to fix upon a spot where his camp might be pitched, and we expected that he would send some one to meet us and conduct us thither. Several Moors ran immediately towards the point whence the sound proceeded: it was actually a Moor sent to us by Sidi-Aly, who informed us that in two days we should reach the camp of the Moors of el-Harib. He was the bearer of letters for several members of the caravan, acquainting them with the state of the country and the prices of merchandise and provisions; part of the evening was employed in reading them publicly, so that the whole caravan shared the benefit of the news. We set out again at ten in the evening, taking a northerly course; and travelled all night over a gravelly soil.

On the 2sth, about seven in the morning, we descended a very steep hill, bestrewed with rocks of granite, soft and crumbling, in strata from twelve to eighteen inches thick. The road was very difficult and even dangerous for the beasts of burden. About ten in the morning, we pitched our tents in a plain, upon a stony soil, and surrounded by hills of granite of the most arid appearance.

I was not suffered quietly to enjoy the shelter which this halt offered us; for the Moors incessantly tormented me. Sidi-Body, the same who proposed to Sidi-Molut to sell me, carried his indignities so far as to strike me. I was obliged to take refuge under another tent, where I lay down for the remainder of the day. The wind blew with violence; I was very thirsty and could obtain no water from my companions. The strangers to whom I applied pitied my situation and gave me a little. I passed the day, without eating; in the evening I was indebted for a handful of rice to the generosity of my new hosts, who awoke me that I might share their meal.

As we approached the encampment of el-Harib, some 
Moors prepared their dress, with the intention of preceding us on the following day, in order, no doubt, to enjoy as soon as possible the pleasure of meeting their families. One of them, the son of Sidi-Aly, my guide, had paid court to me for several days, that I might be induced to lend him my wrapper, his own being torn: as I had less reason to complain of him than of his comrades, during the journey, I consented to lend it to him.

About nine at night, we again decamped and took a north-west direction, as we had done from seven till ten in the morning. 'Toward midnight, we changed our course to N. N. E. through the passes of high mountains of granite, amongst which were pools of salt water. Enormous masses of these rocks, suspended over our heads, seemed to threaten to tumble and crush us. In one of these defiles, the camel that I rode took fright, turned aside and ran away. I was thrown flat on my back upon the gravel.

The pain I experienced was so great, that I was persuaded some of my bones were broken, and indeed that I was near my end. A Moor came to my assistance; he took me in his arms, and pressed me violently against his breast, which afforded me some ease. He assisted me to overtake my camel, which had been stopped, and made it kneel, that I might remount with more ease ; this Moor was a stranger, who did not belong to the company of Aly. My sufferings were still so acute, that I could not restrain my groans; I conceived that my skull was fractured; I experienced a giddiness in my head and could scarcely see. I was not relieved from these symptoms till the following day, and the pains in my loins continued with much violence, so that I could not stoop without great difficulty. I felt the effects of this fall for more than two months. The Moor who assisted me to rise placed me himself upon my camel, which I should have been incapable of mounting without help.

To issue from these defiles, we were obliged to climb a 
steep and lofty mountain; the path was narrow and winding, and presented considerable difficulties, in consequence of which all the company were required to alight from their camels. I alone continued to ride; I was so severely bruised that I should have found it impossible to walk any part of the way. This exposed me to numerous invectives from some of the Moors, who threatened to throw stones at me to compel me to dismount: those, however, who had witnessed my accident took my part, and I was allowed to proceed in peace.

The camels, exhausted by the fatigues of the journey, advanced with reluctance, took two or three steps, then stopped, painfully turning their heads first on one side and then on the other, uttering low moans, while they seemed to measure with their eyes the laborious task which still remained to be accomplished. It was with regret that I found myself obliged to continue mounted, for I pitied these unfortunate animals. The Moors, walking behind, encouraged them with their voices, repeating certain words in different tones, in the way of a song, which the camels appeared to understand.

The track frequently passed so near the edge of the rock, and was so narrow, that I thought it impossible to follow it without being thrown down frightful precipices. At length, having with great toil attained the summit, we discovered an extensive plain, the soil of which, composed of gravel and grey sand, is very hard and interspersed with thin flat stones, resembling slates, and of a grey and black colour.

On the 29th, about two in the morning, the soil changed, becoming more sandy, and offering some traces of vegetation. At daybreak we stopped to perform our devotions; after having returned thanks to God, those who wished to precede us set ont for the camp upon fresh camels and went off at a swift pace. 
We followed them soon afterwards, in a N. N. W. direction, over a hard soil covered with coarse grey gravel. About eight o'clock, we descended into a plain in which the vegetation was tolerably fine; I particularly remarked the tamarisk in considerable quantity. The herbage, though dry, on account of the season, afforded abundant nourishment to our camels.

The inhabitants of the camp, apprised of our arrival, hastened out to meet us : the women presented the children to their fathers, who expressed the greatest joy, embracing them alternately, and affectionately returning their caresses. I was much struck by this interesting scene, and could not avoid comparing it in my mind with the coldness, which annongst the Braknas the wife and children of MohammedSidi-Moctar had manifested on occasion of his return to his family.

About nine o'clock in the morning, we arrived at the dwelling of Sidi-Aly. His camp belonged to the tribe of Body; it was composed of twelve or fifteen tents, covered with stuff made of camel's hair, pitched in a spacious plain, to the north of which rose high mountains entirely bare and running from east to west. My joy on finding myself in an inhabited region was extreme; the idea that henceforth I might quench my thirst at my ease made me forget the fatigue of the desert.

On entering the camp my guide met me laughing, and asked me to give him my hand in token of peace : he inquired after my health and even lodged me in the tent of his aged sister, who was so prejudiced that she durst not approach me. I had soon numerous visits from men and women; for Aly had related to his countrymen the various circumstances which had determined me to cross the desert on my return to my own country. The women, whom I found much more curious than the men, teased me incessantly; they talked all together, so that I was at a loss which 
to listen to. In order to attract my attention, one struck me on the shoulder, another on the head, and another pulled me by my clothes. Sidi-Salah, to whom 1 had in the morning lent my wrapper, gave me some dates for my breakfast; I found them however so hard that $I$ ate but few, which nevertheless renewed the pains in my jaws.

Aly, my guide, had couscous of wheat prepared for two Mahometan priests, of the Trajacants who had travelled with us : I expected that he would have offered me a small share, for I had eaten nothing throughout the day, except the bad dates which had been sent to me; but I was disappointed and compelled to wait patiently.

At sun-set, Aly killed a fine sheep to regale the priests ; the liver and suet were stuck upon skewers, laid upon the coals, and eaten half-raw. He gave me a taste of it; the children and their parents divided the entrails, which they also laid upon the coals.

The remainder of the mutton made a plentiful supper; they gave me a good portion of couscous of barley-meal, adding a small piece of the belly of the sheep which had been reserved. Though this couscous was detestable, both for its want of seasoning and for the great quantity of fat with which it was made, I ate of it with appetite.

On the 30th of June, the women were early at work grinding wheat for the breakfast of the priests. The means by which they obtain the flour separated from the bran is as follows : they have two round flat granite stones, placed one upon another, and set into one another by means of a piece of wood fixed to the centre of the lower stone; the upper has an opening through which the grain is introduced; it is then turned with a handle. Two women are employed in working this machine, although it is neither heavy nor difficult to move.

When the wheat had been thoroughly sifted several times through a sieve of thin canvas, the two daughters of 
Sidi-Aly, as dirty as their father, proceeded to knead it into a cake without yeast: one of them made a great fire of tamarisk wood, to heat the ground on the spot chosen for baking the cake: when it was considered sufficiently hot, they swept the place and laid the dough upon the earth; the embers were then replaced upon it and covered with loose sand which had been heated for the purpose: when half-baked it was washed, broken in pieces, and thrown into a calabash, full of fat, the remains of the preceding night's supper; a kind of sauce was now poured over it and a piece of a sheep recently killed was added. All the family and the priests partook of this stew, and when they had eaten sufficiently they brought me a small portion which remained, with a little sauce upon it; this formed both my breakfast and dinner. On the succeeding days they gave me nothing but dates; I represented to SidiAly that they disagreed with me, owing to the complaint in my teeth, which prevented my chewing them without experiencing severe pain. Aly answered that he was sorry for it, but he had no meat to give me; that in this country dates only were eaten during the day and couscous at night : the remainder of the rice which had been given me at elArawan, was put into his tent, and the family ate of it without ever offering me any. At length, having no remedy, it was necessary to conform to this mode of living upon dates alone: but how much did I suffer! I had soon a sore on the roof of my mouth, and fearing lest $I$ should be again reduced to the dreadful state in which $I$ had formerly been, I gave up eating these fruits, and determined to beg a little camel's milk from our neighbours, whom I found but little affected by my petition. Aly had several daughters whose young lovers were frequently coming to his tent; sangleh was often dressed for their breakfast, but they never once offered me any, though they knew that it gave me such excruciating pain to eat the dates. In three days' time the 
family of Aly began to persecute me ; they conceived they could not do better than imitate the chief, who, on all occasions, manifested an implacable hatred to me. The women appeared to take pleasure in tormenting me; they would not allow me a tent; the moment I lay down to sleep, they played a hundred tricks to oblige me to rise, they pricked me with a piece of wood, dragged me by the legs, took away my wrapper, and threw water over my face. Tired of these endless annoyances I resolved to take refuge in the tent of a good blacksmith who had performed the pilgrimage to Mecca, which was a great recommendation to him in that country: his aged mother was very pious, and received me kindly; she gave me for refreshment milk and water, which beverage they, as well as the Braknas called cheni. The good old woman thought she was performing a meritorious act, acceptable to God, in saying that her tent was mine, and that I might come thither to sleep whenever I pleased. Though a devout Mahometan, she was full of spirits and fond of a joke, nor did I find her given to falsehood like the other women. Sidi-Aly, seeing that his people would not endure me in any of his tents, had one pitched for me alone, but it was impossible to remain in it, for, as the air entered at one side only, the heat was suffocating.

Early on the 2nd of July, the sister of Sidi-Aly came to seek me, holding in her disgusting hands a lump of sangleh covered with hairs, for she had used the same butter to grease her head and to season this mess : though I was exceedingly hungry I had not courage to taste it. This woman, about sixty years of age, took me aside, and said in a low voice: "Listen, Abdallahi, thou who wert brought up among the christians, who know every thing except the path to salvation, thou shouldst be as wise as they are; and I come to pray thee to make me a charm for one of my nieces who wants a husband; if thou consentest, and the charm 
proves good I will provide thee with sangleh for two days." She paused a moment to hear my answer; she then added, that she had induced the Moorish priests to write several for her and had paid them well in dragmes, but that they had produced no effect; she hoped that mine would turn out better. The situation in which I now stood did not permit me to reject this proposition : I only insisted upon the clause that she should not put butter into the sangleh. Without loss of time she fetched ink and a straw to use as a pen. She first told me the name of the desired lover, and the names of his parents, and recommended to me particularly to keep the secret: as she had no paper I furnished her with a little bit, and wrote in her presence the charm she wished for. To give it the more importance, I ordered it to be tied round the neck of the young girl, which was immediately done, and finally, to inspire a high idea of my skill in magic, I traced upon a little board another talisman, directing that the writing should be washed, and that her niece should drink of the watei which had been used for this purpose. This formality having been punctually fulfilled, the girl came to ask me what time would elapse before the charm would operate. As I knew that I should not be many days in the country, I told her that it would probably not be twenty before she was married. Her aunt Ayesha (this was the old woman's name) kept her word; she brought me on the morrow, in a very dirty calabash, some sangleh made of barley-meal and without seasoning. The daughters of Aly, having become more civil since I had shewn my talent for bestowing husbands, ceased to molest me ; they came and offered me some fresh camel's milk, and this was the first time that I had drunk any in the dwelling of my host.

Meanwhile the good old aunt who had so strongly recommended secresy to me, gave her friends information of the happy talent which I possessed, and I soon had to write for the neighbouring camps. All the women of the environs 
made friends with me that, I might give them a charm which would procure husbands for their daughters; they even went so far as to offer me money in payment, which it will be easily imagined I was far from accepting; but I made no scruple of taking milk and sangleh for my support : profiting by this innocent stratagem, I had every day gruel or milk for breakfast. Before chance furnished me with this method of procuring food, I had given my host a little coussabe, entreating him to send me each morning, at least, a small quantity of sangleh : the old hypocrite kept my present, but gave me nothing in return. One day I reproached him for his conduct, and he returned me my coussabe : I changed it for a pair of morocco shoes, for I was barefoot; in the middle of the day, the sun was so scorching, and the gravel and dry herbage cut my feet so much, that I had been obliged to borrow shoes to walk in.

The sons of Sidi-Aly, from twenty-eight to thirty years of age, not wanting my assistance to find wives, did not treat me more kindly than before; they continued to insult me up to the time of my departure ; they even carried their insolence so far as to present themselves uncovered before me using the most indecent gestures. Aly, their father, only laughed at this conduct, which he witnessed.

The Arabs of el-Harib are so harassed by the Beraberas, or Berbers, to whom they are tributary, that they are fearful of travelling even in their own country without an escort from among these people; for if these unfortunate Arabs were met by the Berbers, they would be beaten and pillaged: for this reason we could not proceed to Tafilet without an escort. We were therefore obliged to wait for one of the chiefs of this nation, who lived in a village of the Drah or Draha, and had been sent for.

On the 3rd of July, this chief arrived at the encampment Aly gave him a good reception. They agreed upon the price which each load should pay for transport from el-Harib to 
Tafilet-for this Berber was to furnish beasts of burden; they signed a written agreement in which they mutually bound themselves to fulfil their engagements, and the Berber promised to return in eight days with the camels. Tired of the monotonous life which I was leading in the camp, I resolved for amusement to make a tour among the tribe of Oulad-Gouassim to visit an eminent Mahometan priest, whose sanctity had been highly extolled; his encampment lay about three miles to the east of ours. I approached his tent at the moment when the holy personage was coming out : several old men accompanied him; they had heard me spoken of, and immediately informed hin that I was unhappy, and that $I$ had separated from the christians. He answered with an air of indifference and without appearing to take any notice of me: "Well then! he has to thank God for his return into the way of salvation." I seated myself for a moment upon the ground with him and some of the Moors, who were vicing with each other in obsequiousness to him : he ordered one of them to fetch him a little water, to dissolve some salt which he intended to take as a remedy for an indisposition, pretending that this beverage would give him relief. As the vessel which was brought to him was too full, he was about to pour out some of the water, when one of the Moors in his company, being apparently thirsty, proposed to drink it, but the haughty priest, with a contemptuous air, asked who he was that he should drink out of his satala: the person who aspired to this favour was no doubt worthy of it, for no sooner had he mentioned his name than the priest presented the vase to him. During the short time that I remained in his presence I saw a number of Moors come to consult him on divers maladies ; his only remedy for so many complaints was to lay his hand gravely upon the part affected, and, rubbing it gently, to pronounce a prayer. 'This important person was also the public writer and the instructor of the children. 
The only wealth of this man consisted in his knowledge of the Koran ; but in Africa this knowledge is worth an estate. From all parts they brought him cotton cloth for his dress, stuff for his tent, beasts to carry him on his journeys, and barley for the food of himself and his people : he received all this in exchange for the charms which he wrote. In his camp he was abundantly furnished with whatever could contribute to his support and that of his friends; in return, he gave talismans for the cure or prevention of all diseases, against thefts, or to obtain husbands for the young females.

As it was late and I did not intend returning to Aly's camp, and as the priest had not given me an invitation to sleep in his tent, I sought elsewhere a lodging for the night; $I$ addressed myself as is usual to the first man I met, and requested permission to sleep near his tent: this man received me kindly, installed me in the place which he usually occupied, and left me; he then sent me a supply of dates to serve till supper time. I did not touch them, being afraid of them. During the night I was visited by a Moor, who was a cripple, and obliged to be carried by another. I was lying upon the ground; on rising I was astonished to see this little man beside me; he gave me the idea of a mysterious dwarf; I knew not what to think of his nocturnal visit, and conceived that by the assistance of his companion he intended to steal something. Finding that their presence was not at all to my satisfaction, they desired me not to be afraid, but I assured them loud enough to be heard by the reighbours; that if they did not leave me, I should complain to my host. The deformed dwarf threw himself into the arms of his conductor and they disappeared like lightning. About ten o'clock at night, my supper was brought me: it was good couscous with meat, such as I had never eaten in Aly's family. The chief of the tent brought me water to wash my hands, inquired if I had had a good supper, and took his 
seat beside me : he put several questions relative to the customs of christian countries, and then withdrew.

On the 4th of July, after taking leave of my generous host, I returned to Aly's camp. On the road I met two women, whose conversation amused me a little. They begged me to write charms, one to make her husband who intended to quit her change his mind; another to procure a husband for a young woman who wished to marry: they offered me money in exchange, but warned me, laughing, that they should pay nothing till my charms had taken effect. This conversation made the walk pleasant, and beguiled the length of the way.

We arrived at the camp : the blacksmith, to whose tent I often went to sleep, was preparing to transport two cargoes of ivory to Tatta; I perceived that he paid dues to the Berbers to travel through the country in safety. On making inquiries concerning the place to which they were going, I learnt that 'Tatta is a large town situated five days' journey to the N. W. of our camp: the route leads through the town of Brahihima, which is two days' journey from the camp. The goods taken to Tatta are dispatched thence by the merchants of Soueyrah (Cape Mogador.)

On the 6th of July, the wife of Sidi-Aly, who till then, like the rest of the family had given me tokens of ill-will accosted me in a very affable tone, and requested a saphi for bad eyes; promising me that if I effected a cure, she would give me every thing I wished. To get quit of her I gave her one immediately, and she received it with gratitude. I refused her money, but accepted with pleasure a little milk which she offered me. After some days, the impatient Mariam (that was her name) seeing that my amulet did not operate, reproached me bitterly, saying that my skill was no greater than that of the priests. Knowing from her husband that I had some medicaments, she asked me for physic, which embarrassed me greatly, as I was fearful of 
increasing her complaint; it was necessary however to satisfy her, under penalty of being considered disobliging. Convinced that cleanliness was the best remedy I could prescribe, to force her to it, I diluted with a considerable quantity of water a small portion of sulphat of quinine, and desired her to wash her eyes with it; she insisted that I should perform this operation myself, unfortunately the water, penetrating to her eyes, made them smart a little : upon which she flew into a rage, loaded me with abuse, and in conclusion, cursed both the doctor and his medicines. From that time she gave me no more sangleh.

This incident did not destroy their confidence in my saphies, to the credit of which moreover old Aly had contributed by a falsehood; having asserted that when I left Timbuctoo my abdomen was much swelled, and that I wrote in a book, washed my writing in water, and drank this liquor, which cured me.

An old woman long tormented me to procure a husband for her daughter ; she dragged me, at length, against my will into her tent, which belonged to a neighbouring camp, promising me a draught of cheni in recompense. Here I saw the object of her maternal solicitude; a girl about iwenty years of age, repulsively ugly, clothed in rags, the filthiness of which could only be equalled by that of her person. Her left cheek was covered by a scar, and she had sore eyes. Her whole figure presented the most revolting appearance imaginable; and I perceived at a glance the cause of her mother's anxiety to get her married by means of a charm. I felt that it was quite beyond my art to accomplish such a prodigy. To induce me however to exert all my skill, the old woman offered me a piece of dried meat, which she took out of a large leathern sack, where, from its state of putrefaction, it might have been deposited on the day that her amiable daughter was born. Notwithstanding the repugnance which I manifested, the mother in- 
sisted upon my acceptance of the delectable morsel, which she assured me was excellent; but such was iny disgust that I even refused the cheni which she offered. I was anxious to withdraw, but could not effect my escape till I had written the amulet required; this done, I fled with all expedition, invoking for the maiden a man courageous enough to take her to wife.

I have never, in any country, seen women so dirty as those of el-Harib. This total want of cleanliness is no doubt the cause of the chronic ophthalmia, and other disorders, with which they and their equally filthy offspring are afflicted. My medical reputation drew upon me most unpleasant avocations : the mothers brought to me in crowds children in so disgusting a state that I could not look at them without horror; in vain did I avert my eyes, they only became more importunate, compelling me to examine the miserable beings for whom they solicited my aid. I could do no better for them than recommend cleanliness; but this simple remedy they despised, and would not be content with any thing short of the marvellous.

On the evening of the 6th, a troop of Berbers arrived in our camp demanding hospitality. Aly ordered for their supper a couscous of wheat flour, to which were added some pieces of meat dried in the sun. The food for me and the slaves was separately dressed; but Aly's sister, who, since I had given her amulets for her nieces, had become much more attentive to me, gave me some of their meat concealed under the bad couscous of barley intended for me.

On the 8th of July, another troop of Berbers carried off several camels which were grazing at a distance. The whole camp took the alarm, and arming themselves with guns the men set off in haste, some on foot and others on horseback; but the thieves were already distant, and their pursuers returned without having overtaken them. The evening was 
spent in lamentations on the part of the owners of the camels, their relations, and friends. They had recourse to fortune-tellers to know if they should recover them; and came to consult me on the subject, requesting a charm to bring them back; this I refused, under pretence that my writings did not possess that virtue.

On the 11th of July, the Berbers who were to escort us to Tafilet arrived, and great was my joy to think that on the morrow I should quit a place where I had experienced so many mortifications. Aly had a sheep killed for the Berbers' supper and gave me a little bit, with an apology on account of the many persons who were to partake of it.

On the 12th, at five o'clock in the morning, our preparations were made for departure; but before quitting this country I shall give a description of it.

The territory of el-Harib, two days' journey west of that of el-Drah, and one to the east of the tribe of the Trajacants, is situated between two chains of mountains, which extend from east to west, and separate it towards the north from the empire of Morocco, to which it is tributary. The inhabitants are divided into several roving tribes. Their principal wealth consists in the great quantity of camels which they breed, and which in the wet season produce abundance of milk for their sustenance. All the Moors of el-Harib travel in the Soudan; they go to Timbuctoo, elArawan, and Sansanding; the merchants of Tafilet, elDrah, and Soueyrah, give them loads for their camels; on their own account they carry only wheat and dates, and these in small ventures. When in the Soudan they remain there several months, for the purpose of traffic; making little journeys to Toudeyni, where they purchase mineral salt, which they sell again to the principal merchants in the two chief entrepôts, receiving in exchange grain, the stuffs of the Soudan, and gold. Having spent nine or ten months in this traffic, they take a load for Tafilet or some other city, 
and afterwards return into their own country and to their family, bringing with them gold only and some slaves, whom they sell in Morocco.

On returning to their own country, they are obliged to pay a small tribute to a chief called the sheikh. The goods brought by the Moors from the Soudan to el-Harib are transported to Tafilet or other places by the Berbers alone, or under escorts which they furnish at a price agreed upon; without which precaution the merchants would certainly be robbed or murdered on the road.

The Moors of this miserable country are incessantly harassed by the Berbers, from whose habits of rapine they have every thing to fear, although they pay them a heavy tribute; and not one of them, whatever rank he may hold at home, dares travel without being thus accompanied. These roving people, not being themselves cultivators of the soil, are obliged frequently to go to el-Drah to purchase barley and dates for food, and not daring to attempt this without the convoy of the Berbers, they pay them an additional tribute by way of remuneration. These latter, well armed, are contitinually prowling about in the country of el-Harib, to obtain food from the Moors and even to carry off their cattle.

The inhabitants of this district are so poor that they can purchase only the cheapest provisions, principally such dates as, having fallen from the trees before they have become perfectly ripe, are carefully picked up by the owners, exposed to the sun to dry, and then put into leathern bags, where they become so extremely hard that very good teeth are requisite to eat them without pain. Upon these dates, which they pound in a wooden mortar, and a little cheni, the Moors of el-Harib subsist during the day; eating sangleh before evening only in very particular cases.

About eight or nine at night, they usually sup upon a couscous of barley generally steeped in warm "water, in which they have boiled a handful of herbs gathered in the 
environs of their camp. They also breed some sheep, but when they kill one, which is very rarely done, they dry the meat and preserve it in leathern sacks, sometimes for six months. They have recourse to this reserve when they treat strangers, particularly the Berbers, to whom they are very attentive. As a mark of consideration, they spread before the tent for their repose a carpet as good as those which we use in Europe. The master, in honour of his guests, frequently eats with them from the same bowl, and, instead of offering them pure water, he adds to it camel's milk, which in the rainy season is very abundant. On the arrival of the strangers, the dates and cheni are immediately set before them as a refreshment till the supper hour. Though the Moors of el-Harib receive the Berbers thus hospitably, yet in travelling through their country they are never treated even with a supper; in their journeys therefore, they are careful to carry their provision of dates and a little barleymeal, which they boil in water. The costume of the Berbers differs from that of the Moors only in a band of coloured stuff, which the former wrap round their heads in the form of a turban; they also wear ear-rings. They are all armed and mounted on fine horses, handsomely caparisoned, and they wear spurs, which are attached to a leather strap firmly fastened round the instep.

The Moors of el-Harib dress like those on the banks of the Senegal, except that over their coussabe they wear a linen wrapper manufactured in the country of el-Drah or Tafilet. They have only one wife, but like the Braknas change her frequently. They are all Musulmans, yet they do not addict themselves, like the marabouts, to the study of the Koran, being satisfied with knowing the first verse of it without learning to write; a marabout is, consequently, held in great consideration among them.

The Moors of el-Harib are generally detested by their neighbours; in el-Drah and Tafilet they are seldom called 
any thing but cafirs or infidels. In my life I never saw women so evil disposed and so dirty as those of this country: they do not veil themselves, like the women of Morocco, but expose a face disgustingly filthy; the smell that proceeds from them is most offensive. The inhabitants eat the camels which have died from fatigue, but not till they have drained off the blood; they keep some sheep and a few horses. El-Harib contains eleven tribes, the names of which, as I received them from an old inhabitant of the camp, to which I belonged, are as follows : Oulad-Rossik, Oulad-Wébal, Oulad-Gouessim, Oulad-Foulh, Oulad-Ouraff, Oulad-Rouzinn, Oulad-Rahan, Oulad-Nasso, Oulad-Body, Oulad-Bonlaboi, Oulad-Sidi-Ayesha. One day's journey west from our camp are situated the first tents of the Trajacants; at the distance of four in the same direction are the tribes of Oulad-Noun, who dwell near the village of Adrar, which must not be confounded with the country of el-Drah, a small district extending from east to west, and from north to south, between Morocco and el-Harib; five days' journey west from the encampment of Sidi-Aly is the village of Sous; at fourteen days in the same direction that of Soueyrah; and at ten or eleven days from el-Harib, to the N. N.W. is Morocco, the capital of the empire of that name, which these rovers sometimes visit.

While the men of el-Harib are travelling in the Soudan, the women employ themselves in making ropes of grass, to fasten the baggage and to draw water from the wells in the deserts; they spin camel's hair with which they make tent-covers; they prepare and tan leather, and make sandals for their husbands, and the remainder of their time is devoted to their domestic concerns. As in all other Mahometan countries, they eat apart from the men.

Sidi-Aly had frequently teased me to part with my two pieces of blue cotton cloth from the Soudan, that I 
might have, he said, the means of purchasing provisions for my journey to Tafilet, those which had been given me at Timbuctoo and el-Arawan, having been wholly consumed by himself and his family. Wishing to retain my cloths, which might probably prove serviceable to me in future, I resisted his importunities, and this cheating his cupidity ran the risk of exposing myself to his resentment. My resolution, however, produced no ill consequences. 


\section{CHA PTER XXV.}

Country of el-Drah.-Zawât.-el-Hamid.-Bounou.-Town of Mimcina.-Camp of Berbers.-Tabelbât.-The Tawâts.-Wells of Yeneguedel, of Faratissa, of Bohayara.-Customs of the Berbers.-Wells of Goud-Zenaga, of Zenatyia.-Town of el-Yabo.-Wells of Chanerou, of Nyela.-Arrival at Tafilet.-Town of Ghourland.-Market.Ressaut, the residence of a Governor under the emperor of Morocco.

ON the 12th of July, we set out at five in the morning, after having taken a little camel's milk, which I bought with a glass bead from my chaplet. We proceeded slowly towards the east, over a hard soil, composed of grey sanü, covered with vegetation, and intersected with deep ravines. Aly would not permit me to mount my camel all the morning; it was not till towards noon when he mounted himself that I could obtain this favour. About two P. M. we halted on a very hard sand upon which grew some zizyphus lotus; throughout the day a strong easterly wind incommoded us much : at four in the evening it veered to the west. At nightfall we were visited by a Moorish priest whose camp was in the vicinity of our halting place. As he was proprietor of several flocks of sheep, we wished to purchase some mutton of hin but he refused; and we gave him some barley-meal which he undertook that his wife should dress for our suppers. He sent it to us at ten o'clock, and had the civility to add some milk from his ewes. Out of reserve he declined supping with us, but seated himself apart and waited till the dish containing our mess was brought to him.

On the 13th of July, at two in the morning, we continued our route E. N. E., and crossed several sand-hills covered with dry shrubs. About eight o'clock we passed 
the ruins of some mud-huts, surrounded by a battlemented wall; opposite to these ruins is a small square mausoleum, the roof of which is a vaulted arch. Immediately within the little entrance door, is stretched a cord from which depend numerous shreds of cloth of various colours, which travellers had hung there from a sentiment of devotion. Several pyramids of flint heaped together without cement, and about eighteen inches in height, are another kind of offering made by passengers to the manes of the sherif whose ashes repose in this monument, and whose memory is held in veneration.

Here the Moors and Berbers of our little caravan went through their devotions; after a short ceremony they took a little sand from the place in which they had prostrated themselves and sprinkled it over their camels and slaves. 1 learned that these ruins belonged to an ancient village called Zawât, long since abandoned by its inhabitants, who had elsewhere founded another town of the same name.

The soil of the environs is barren, hard, and full of stones of various colours; a few bushes indeed are to be seen, but their foliage is parched up by the sun.

It was noon when we passed the new village of Zawât, which belongs to the country of el-Drah. This village is peopled by the former inhabitants of the deserted ruins we had seen in the morning : the houses are of stone, with terraced roofs, and consist only of a ground-floor; they are ill-built and resemble the huts of the Bambaras. We crossed some fields which had been cultivated, and about half past twelve halted in a wood of date-trees, near a neat village, called el-Hamit. Nothing was to be seen on all sides but forests of date-trees majestically rearing their summits to the clouds. Under these trees the inhabitants of el-Drah cultivate wheat, barley, and some garden vegetables. They divide their land, the soil of which is a fine sand but fertile, into little squares, round which they raise 
dikes to receive and retain the rain-water, and when they have collected more than they want they convey the surplus by channels to the foot of the date-trees. Each landholder has in the middle of his field a well of clear and good water, sunk to the depth of twenty or twenty-five feet, in a hard sand mixed with small black and yellow pebbles; I remarked several having strata from fourteen to eighteen inches thick of red sand a little veined with grey and of the consistence of clay. Two posts fifteen feet high are erected, one on each side of these wells supporting a crossbeam, to which is fastened a long pole, bearing a weight at its hinder extremity to counterbalance the bucket which is attached by a piece of cord to the other; the water is thus drawn up without much effort and serves to water their plantations. At the depth of about twenty-five feet are found rocks which appear to be of granite. Wood is very scarce in this country; the fuel consists only of dry palmleaves and the trunks of dead trees : the timber used in the construction of their houses is that of the date-tree.

The plough is used in this country, and it is drawn by mules or camels.

Near sunset the Berbers collected some small pebbles, which they arranged symmetrically upon the sand, then heated them with a fire of palm-leaves, and, after kneading a little barley-meal, baked a cake of it for our supper upon the stones; to improve it they mixed with the meal some small bits of mutton fat; when baked it was divided among us. Aly gave me a little bit of it which I thought delicious, although badly baked and very heavy, for I had tasted nothing the whole day; my guide, however, though he allowed me so little nourishment, upbraided me with living at his expense, since my own provisions had been long exhausted. Happily for me two Trajacant marabouts had joined our caravan; Aly supplied them with provisions, and allowed them sometimes to ride his camels, not out of humanity, but because he would have 
utterly forfeited his reputation as a pious Musulman had he acted otherwise. These two men were excellent company to me : they consoled me ander the insults to which I was incessantly exposed, and greatly alleviated the hardships of my lot during this long and toilsome journey ; for I should probably have encountered still worse usage but for their presence, which imposed some restraint on my guide and his family. The marabouts had even the kindness to give me drink, when, as it frequently happened, water was refused me.

On the 14 th at three in the morning, we took our departure, slowly directing our course E. N. E., through numerous plantations of dates; the soil was broken by hills of loose sand.

About eight in the morning, we passed a large village called Bounou, surrounded by beautiful palm-trees. About ten we came to a hard soil covered with small black and yellow pebbles; here we met six Berber horsemen, all well mounted, and armed with sabres and muskets; they advanced at full speed to meet us with hostile intentions, pointing their loaded muskets : the six Berbers who formed our escort, with four well armed Moors, placed themselves at the head of the cavalcade, holding their weapons in readiness to receive the enemy. The two parties halted within a certain distance, when the Berbers parleyed together in their own language, still holding their muskets ready for firing. As soon as they recognised each other to be countrymen, they saluted; and we pursued our route without molestation. What a country is this, in which it is impossible to stir a step without danger of being robbed and even murdered by one's neighbours! We continued our course in the same direction over a hard and stony soil, and passed an ancient village in ruins, where the minaret of a mosque is still to be seen; beside it is a well at which travellers quench their thirst; one of the Trajacant Moors 
gave me a little of this water, which I found tepid and bad. I also observed a mausoleum, like that which we had seen the day before, and where the Musulmans again performed their devotions. Proceeding in the same direction, we met some wretched Moors, leading asses laden with forage; these men were badly clothed and walked barefoot.

About noon we encamped in the fields under the shade of some date trees and not far from Mimcina, a large town of el-Drah, inhabited by Berber and Moorish hushandmen. This town, surrounded by walls twelve feet high, is situated between two chains of hills stretching east and west, the soil of which every where presents a reddish hue, without any trace of vegetation.

As it was hot, and our people were not yet returned from watering the camels at the wells, my thirst became extreme, and I determined to visit the tents of the Berbers, pitched at a short distance from our own, to beg a little water.

No sooner did I approach the camp than three large dogs rushed upon me, tore my garments and bit me in several places. I cried aloud to the Berbers for assistance, but these unfeeling wretches carelessly looked on or turned away with the utmost indifference: assailed by so many enemies I found the combat very unequal; and, for fear of being torn in pieces, sounded a retreat, still sustaining some bites as I retired: the dogs carried off some pieces of my dress as trophies, and did not leave me till I was at a considerable distance from their tents. Heartily cursing the inhumanity of their masters, I returned sorrowfully to our own camp under the date-trees. The Berbers keep a great number of dogs to watch their flocks, and they are so accustomed not to suffer the approach of any stranger what. soever to the habitations of which they are left in charge, that the fear of being devoured by them serves as a wholesome restraint upon the depredations of those robbers by 
whom the country is so much infested. The Berbers themselves dare not approach without caution the camps of their own tribe to which they are strangers; but, if business obliges them to repair thither, they take the following method to escape the fury of these pitiless guardians. The visiter advances slowly, and makes a circuit round the tents at a considerable distance; the dogs begin to bark, without advancing on account of the distance; as soon as the owners of the tents shew themselves, he acquaints them with the object of his coming, when they are anxious to satisfy him; if he applies for hospitality, supper is spread for him on a mat at a short distance from the tents, which no one is ever allowed to enter.

At five in the evening, when the heat was abated, I took a walk to the town of Mimcina, accompanied by a neighbouring Moor, who, being a friend of Sidi-Aly's, had come to visit him and brought him a present of dates, which, by the invitation of the donor, we ate together. The chief of our Berbers strongly recommended me to this Moor, and charged him especially to guard me from insult and not to suffer me to be robbed of the pagne which I wore; a recommendation which gave me but an indifferent opinion of the people whom I was about to visit. The town is walled and surrounded by pleasant plantations of palm-trees. I observed under a shed near the gate a party of loungers, who, as soon as they saw me, crowded round me asking a thousand ridiculous questions, for they were already apprised that I was an Arab who had escaped from the christians. With some trouble I got quit of these impertinent fellows, and, penetrating into the town, I passed through a very narrow, winding, and dirty street; the walls of the houses are at least fifteen feet high and very badly plaistered. I was followed by a crowd of men, for the women were veiled and durst not look at me. I seated myself under a gallery, where many old men were col- 
lected together in conversation with one of our Trajacants, who had been in the town all day, and had already related part of my history to the assembly. Among the crowd was an aged Moor, who, having performed two journeys to Mecca, had acquired great preponderance over their counsels: this man talked to me a long time about the christians, and shewed me a fac-simile of the manner in which Christ is represented in Europe; he tried to chant in imitation of the priests whom he had heard at Tripoli in Barbary, and often repeated, striking his breast, amen, amen. He asked me if I was disposed to eat some dates, for which I thanked him. The Trajacant marabout told him that I was with a guide named Aly, who persecuted me in order to force me to sell my dress and purchase provisions for the journey; the old man appeared incensed at such perfidious conduct, and declared that such a person could not be a good Musulman. He inquired whether I would like a present of dates, which I accepted; and he immediately ordered those about him to provide me with a sufficient quantity to last till our arrival at Tafilet; and leading me to the mosque reiterated his orders. After the prayers, a great quantity of dates was brought to me, enough indeed to load an ass; but unfortunately they turned out to be spoilt and bad: these good people carried their complaisance so far as to carry them to our camp; bad as they were, Aly, the covetous Aly, received them with pleasure, and on that day behaved better to me than usual.

The houses of Mimcina consist of a ground-floor, only; like those of Timbuctoo, they have terraced roofs, and admit the air only from an inner court. I saw several dirty Jewesses, covered with rags, walking barefoot, and displaying the utmost extremity of wretchedness. The inhabitants of Mimcina have but few beasts of any kind, and scarcely any oxen or horned cattle : they breed a few sheep for the sake of their wool, some goats and poultry; they are excellent husbandmen, and have many date-trees, in which their wealth prin- 
cipally consists. Their breakfəst is composed of bread with a little gruel made of barley-meal; and they sup upon couscous. About seven o'clock a plentiful couscous with mutton was sent to Sidi-Aly, who, after having made his own supper with two or three persons whom he looked upon as his equals, shared the remainder between me and six cameldrivers, who were not admitted to his table: the poor slaves also, to my great satisfaction, were not forgotten. We afterwards lay down under the palm-trees, the broad leaves of which formed a canopy over our heads, and I, contrary to my usual habit, slept tolerably well.

On the 15th, at three in the morning, we took leave of the town of Mimcina and its inhabitants; and, bending our course E. N. E., traversed a hard soil of white sand, with a surface of small pebbles of the same colour, mixed with gravel; the country is diversified with hills of an extremely arid appearance. The Moors of Mimcina informed me that Beneali, the residence of the chief of the Berbers, is situated N.N.W. of their town, at the distance of a day's journey, on the road to Morocco. This nation, according to their account, pays no tribute to the emperor.

A day's journey from Beneali in the same direction lies the village of Amsero; a days' journey beyond that Ranguerute, a large town, and six days farther still Morocco, the capital of the empire.

Six days' journey east of Mimcina is situated the town of 'Tabelbât, on the road to Tawât, which is eight days' journey beyond. The Moors of 'Tawât are husbandmen; they have numerous palm-trees, trade with Timbuctoo, and occasionally visit Tafilet and el-Drah to purchase goats and sheep.

Pursuing our route, we arrived at the wells of Yeneguedel, where we halted: a quarter of mile to the south we saw a delightful grove of palms, offering a striking contrast with the barrenness of the neighbouring mountains; but our guides neglected this spot, where we might have enjoyed the shade, and left us exposed to the scorching sun, which on 
that day was more than usually powerful. I visited the wells, situated on a little hill, as bare as the neighbouring country, and there found a single drooping mimosa ferruginea, under which I stretched myself, and, resting my head on a stone, slept soundly. On awaking, I approached the wells to drink, and saw there some Berber women watering their sheep : the wells are three feet deep, and their water is good and abundant; they are sunk in grey sand, containing many calcareous stones of a flat shape. On our departure from Mimcina, we had been joined by a Moor from Tafilet: he and his train were mounted upon mules, the animals most commonly used for travelling this stony road, which is apt to wound the feet of camels; those of Sidi-Aly were however obliged to carry his goods.

The Berbers had a barley-cake baked upon the ashes for our supper ; each of us after this light repast, drank a glass of cold water, and lay down for the night on the stony ground. On the 16th, at three in the morning, we proceeded slowly N. N. E., till near eight, when our course was changed to the north. Our march lay over a very mountainous soil, covered with sharp stones, which were very troublesome. The mountains are not high, and composed of granite without any appearance of vegetation. The Moor Sidi-Boby, who still perpetually insulted me, threw a stone at me, which striking me on the right side, hurt me much, and Iretained the mark of it a considerable time : this brute had no other cause for such savage treatment than my having mounted my camel without giving him notice. Old Aly, seated upon his, had preceded us; immediately on rejoining him, I complained of the outrageous treatment to which $I$ had been exposed; but he paid little attention to me and answered laughing: "'That is nothing, all will be well." Exasperated by his conduct, I told him that if all was well with him, all was very ill with me: he was silent, and turned his head another way. I ought to repeat here that it was to the two Trajacant marabouts alone that I was indebted for not encountering still 
worse treatment from such men, in the journey between elDrah and Tafilet: I thanked them for it; but for them I should have been obliged either to desert, or to seek another guide to conduct me to Ghourland. The Moors of my company were restrained from doing me greater mischief solely by the fear of passing for infidels.

About ten in the morning, we halted near the wells of Faratissa, agreeably shaded by beautiful palms : in the envi rons are some veins of sand, studded with patches of grass on which the camels are accustomed to browse; stunted mimosas are also scattered around. The wells are but two feet and a half deep; the water is very good.

From el-Drah, our little party had been increased by several Moors; they all assembled round the wells, and talked much about me; with the exception of my guide all appeared to take an interest in my fate : fears were expressed that on my arrival in Alexandria I might not meet with any parents. "Poor young man," said they, "what will he do all alone ?" I told them that I had full confidence in God, who had supported me through a thousand dangers and would not abandon me at the moment of reaching port. "In short," said 1, "if God has called to himself my father and mother, he will have left me a brother and a sister."

On such occasions Aly spoke highly in my favour and even pitied me: this day he carried his kindness so far as to shave my head, a compliment which I would willingly have dispensed with; but, as it was a religious duty, I could not complain. In the very act he proved his hypocrisy by insulting me, and encouraging his slaves to follow his example. To escape these persecutions, I took refuge in the tents of the Moors, our fellow-travellers, where we passed the night under the palms, the coolness of whose foliage invited us to sleep. The camels and mules not having had water the whole day, we rested till three in the afternoon of the $1 \%$ th. 
The intense heat having then moderated, we proceeded northward, over a soil similar to that of the preceding day. About half past six we stopped, and each of us supped upon a piece of barley-cake and some dates. After this meagre repast, we again stretched ourselves upon the stony ground, where I slept soundly till about three in the morning of the 18th, when we started afresh.

As my guide was fearful of fatiguing his camel, he obliged me to walk the whole morning: I therefore followed on foot the little caravan, which slowly advanced towards the N. N. E. over a gravelly soil; the face of the country was covered with hills composed of rocks of granite. About nine in the morning, we halted at the wells of Bohayara, around which the vegetation is luxuriant; they are twelve feet deep, and sunk in grey sand, mingled with coarse gravel. They are very near to a camp of Berbers, who water their sheep and goats at them: these men inhabit the passes of the mountains, where they feed numerous flocks of sheep and herds of camels, and cultivate a little barley and wheat. They are rovers, but change their place of abode less frequently than the Moors, and whenever occasion calls them to a distance from their little fields, they always leave some one behind to take care of them.

I found the Berber women much cleaner and less curious than the Moorish. They dress like the latter in old rags, but take care to wash them. These women, whose good looks proclaim that they live in plenty, colour the tips of their noses and chins blue; they envelop their heads in ragged cloths of red or white worsted, and wear their hair in tufts behind their ears, and fastened in rolls at the back of their heads. Their principal ornaments consist of necklaces of amber, coral, and various kinds of glass-beads, and in silver bracelets and anclets; their skin however appeared to be as dirty as that of the Moorish females of el-Harib. They are industrious, and employ themselves in spinning the wool of 
their sheep, and weaving the yarn into blankets, which they sell at Tafilet. These Berbers have a peculiar idiom, which the Arabs do not speak; they also conform to the religion of Mahomet; they have several wives, who superintend all the household concerns, prepare the food, take care of the sheep, and have besides the laborious task of drawing water for them to drink. They pasture their flocks in the passes of the mountains wheresover they can find herbage, for the appearance of their own country is absolutely bare. Hills of granite, of moderate height, but totally destitute of vegetation, meet the eye on all sides. This wandering and pastoral tribe subsist like the Moors, upon dates and sangleh made of barley; they often make their supper upon couscous, or barley-cake, baked upon the ashes. In the rainy season, the milk of their flocks, being then more abundant, forms a portion of their nourishment. Such of them as live in the villages have houses in the Moorish style, tuilt like those of the Arab inhabitants of the towns : the re vers have only tents, the coverings of which are made of the hair of their camels. They grow but little grain, the land which they occupy being scarcely fit for cultivation; but here and there may be traced veins of more fertile earth which they turn to good account.

Their cookery, like that of the Moors of el-Harib, is performed in large copper vessels, manufactured by native smiths. It is astonishing that they escape being poisoned by the verdigris, for the Moorish women are so excessively dirty that they never wash their utensils, merely rubbing off with the hand what adheres to the sides.

The Berbers encamped at Bohayara presented Sidi-Aly and our escort with a sheep, which had a particularly fine fleece, and was killed by the Berbers of our company for our supper. As we had no vessel to boil it in, our guides had recourse to the ingenious expedient of picking up a number of large smooth calcareous stones, with which they formed a small oven, and heated it with roots of hedysarum alhagi, 
the only combustible that grows in this part. The entrails of the sheep were converted into chitterlings and the carcase was cut into many small parts.

The oven, when strongly heated, was carefully swept, and the pieces of mutton put in one upon another; it was then hermetically sealed with loose sand. When the meat was properly dressed, the chief of our Berbers, who was a lover of justice, secured its impartial distribution by giving each of us a bit of wood, which, being duly marked, was brought to one of the Moors appointed for the purpose. He was ordered to shake them together, and taking them up at random, to place each upon a piece of the meat: thus every one was entitled to his own lot. I had also my share, for which I was solely indebted to the chief of the Berbers, who had been often indignant at the conduct of the Moors towards me. The meat was pretty good, served with cleanliness, and perfectly well dressed.

On the 19th of July, at four in the morning, we quitted the delicious wells of Bohayara, slowly directing our course N. N. E. over a soil covered with small grey gravel; on either side of our route was a chain of low, bare hills, containing abundance of black granite, in huge detached blocks; and the country was still naked, presenting its usual appearance of frightful sterility.

About ten, after proceeding at the rate of three miles an hour, the wells of Goud-Zenaga afforded us a resting place; here we found some Berbers from an adjacent camp who were watering their flocks. The aspect of the country around led me into reflections upon the habits and character of these people; it seems inconceivable how they can contentedly take up their abode in such dreary regions, producing nothing but scanty herbage, and neither tree nor shrub of any kind.

On the 20th, at four A. M. we again pursued our course to N.N. E., over a nearly similar soil, but somewhat stony ; the chain of hills still continued equally bare. 
At eleven, we halted at the wells of Zénatyia, twenty or twenty-four feet deep, yielding abundance of tolerably good water. The surrounding soil presents a pleasing appearance of vegetation; some mimosas and zizyphus lotus flourish there, together with a number of very tall tamarisks, which afforded us an agreeable shade. The level is broken by hills of loose white sand, the abode of numerous antelopes, one of which was killed by a Moor of our party, and divided amongst the whole caravan, allowing only a small share to each.

A day's journey $\mathbf{N}$. W. of the wells of Zénatyia, is a Berber town, called el-Yabo, and one of its inhabitants who belonged to our caravan parted from us here to return home. The husbandmen of el-Yabo extend their labours, during the rainy season, as far as Zénatyia, preparing the ground for wheat and barley, which they cultivate in small quantities.

On the 21st, we again proceeded towards N. N. E., at four in the morning, travelling three miles in about an hour, among the hills of loose sand. We then came to a plain of smooth sand firmer than that of the hills, covered with small gravel and pebbles. About ten, we halted at the wells of Chanérou, where we found some Berbers watering their sheep, the fleeces of which are remarkably white.

Near these wells I observed a small shed, constructed of the branches of the zizyphus lotus, and covered with straw and brambles: here $\mathbf{I}$ took shelter in company with some Moors, and three Berber women, who left the task of questioning me to the men, paid apparently but little attention to my adventures, when cursorily related to them; but my person seemed to attract much of their notice, and to please them greatly. Now and then I asked them for some water; which they good-humouredly gave me from the bucket, carefully holding it in a position that enabled me to drink with ease.

The plain, in which these wells are situated, is gravelly, interspersed with rocks, and inclosed by sterile hills, which 
seem to be about three hundred and fifty feet in height. A little grass grows in the clefts of these rocks, and serves the sheep for pasturage. We had been joined in the morning by a Moor from Tafilet, who came to meet his father. The old man, whose name was Sidi-Abdoul-Rahman, was about fiftyfive or sixty years of age, and nearly bald : he was returning to his native village, Ghourland, after a long residence at Timbuctoo; where he had seen Major Laing, as he informed me by the way. His son brought him some black grapes for his refreshment; he gave me a bunch with a small bit of wheaten bread, which I accepted with pleasure. Little, indeed, had I expected to eat fresh bread and grapes in so sterile a country! In the evening, some troops of Berbers came to water their flocks. Sidi-Aly proposed to buy a sheep for our supper, the Berbers of another troop joined us, and twenty of them contributed towards this purchase; each gave for his share a dragme, the coin of the country, worth about eight French sous. Sidi-Aly whom I had allowed to see that I possessed three or four shillings, consented to lend me this dragme, which I promised to repay on our arrival at Tafilet. I must here anticipate by observing, as a fact which greatly surprised me, that at parting he would not accept payment; desiring that $I$ would keep this piece of money to assist me on my journey to Fez, and saying that he gave it me for the love of God. It was doubtless from remorse of conscience which he wished to silence at a cheap rate. The mutton thus procured, and which was dressed like the last, proved delicious, though it had not been so carefully cleaned.

On the 22nd, at two o'clock in the morning, we set off in a N. N. E. direction; the soil still the same, and the mountains extending on both sides of our route. About ten in the forenoon we halted at the wells of Nyéla, (or Ain. Yela) the water of which is abundant and good; they are situated in a very stony ravine, and so shallow that the water 
is taken up by hand. The heat was extreme, and our only shelter some of the zizyphus lotus.

At a short distance south of the wells is seen a high mountain of granite, in the crevices of which there are a few patches of verdure: I observed on its declevity a flock of sheep, which appeared no larger than young lambs. This mountain is nearly pointed, and rises to the height of one hundred and fifty or two hundred fathoms above the level of a very stony soil. When my fellow-travellers had retired to rest for the night I went to the wells with a satala, and washed myself in the cold water, which afforded me much comfort; returning afterwards to my companions and lying down on the ground, I slept soundly till three o'clock in the morning.

On the 23rd, I was still half asleep when we set out, proceeding for the first half hour in a N. N. E. direction; we afterwards turned to the N. E., till six in the morning, and, quitting the barren mountains, descended into a plain of very hard grey sand, susceptible of cultivation.

From this plain we beheld the beautiful and majestic palm-trees of the country of Tafilet, an enchanting prospect and one which raised my spirits by announcing the speedy alleviation of my sufferings. We passed through fields, separated, some by earth walls, and others by narrow ditches. The country was beautiful, but parched up by the scorching heat of the sun, which left no other verdure than the evergreen leaves of the palm. About nine in the morning we reached Ghourland, and were presently surrounded by a crowd of children, attracted by curiosity. We encamped under the shade of the palm-trees, at the gates of the town. When the arrival of our caravan from the Soudan was reported, numbers of dirty and ill-clad Moors and Jews came to meet us, and soon surrounded the baggage : many of my companions warned me to be careful of my leathern bag and of my pagnes, or they would be stolen, even off 
my back; they advised me not to go too far from the village, because there were thieves, who, in the supposition that I had brought much gold from the Soudan, might attack me. The Moorish meichants who came for their goods made a single mule carry the burden of a camel. I took mine upon my shoulder and followed my guide to the house of old Haggi-Le-Mekke, the chief of Ghourland. I passed in my way through several long and narrow streets, and arrived at the house of my new host. An inner court formed the entrance both to the chambers and magazines. Part of this court was covered by a shed, supported by trunks of palm-trees, in the middle of which was a sort of sky-light. A staircase of earth led to the terraced roof of the house. I deposited the bag containing my notes in a locked-up warehouse, and, tl:e bag itself being padlocked, I was set at ease respecting the curiosity of the Moors. Our host gave us for breakfast some excellent dates, so ripe that they resembled preserves, and added a small piece of new wheaten bread: this would have been a sumptuous regale, had not the water which we drank with it been brackish. The young sons of Haggi received me kindly; they congratulated me more particularly upon the resolution I had taken to forsake the christians and unite myself with the Musulmans; telling me that I was under the special protection of God, and that all who should do me good would be favorites with the prophet. I need not, they added, feel any further uneasiness as to my return to my country; now that I was at 'Tafilet, I should find no difficulty in reaching the place of my birth, and they would themselves defray the expense of my journey to Fez, which should cost me nothing. In conclusion, they invited me to remain with them, assuring me that they would supply all my wants.

My new hosts seemed so well disposed towards me that I expected an apartment at their house, but was disappointed, for, after breakfast, they recommended me to go and engage 
a lodging at the mosque, an edifice destined at once for the service of God and the reception of travellers. In fact, I there met with several strangers, who surrounded me and overwhelmed me with questions.

About two in the afternoon, I returned to the house of my host, to relieve the weariness which this importunate curiosity occasioned me, and was greatly astonished to find the same young men, who in the morning had expressed so much affection for me, now refuse me admittance. After having explained that they treated me thus on account of their women, they asked me if I wanted food, and, giving me about two ounces of bread with some dates, left me seated upon the ground at the door. After having taken this slight repast I returned to the mosque. About ten o'clock, the negro slaves came to call Sidi-Aly and his people to supper : as he would not allow me to eat with him, I received no notice; however, finding the time elapse, and being by no means disposed to lose my supper, I determined to seat myself at the door of my host's house. 'The slaves, as they passed, inquired what I wanted; I answered that I had had no supper, and beggea they would inform their master: they executed my commission, and returned saying, that I ought to have shared the supper of Sidi-Aly and his suite. I then described their misconduct towards me, at which they were indignant, saying, that he and his were infidels; and, desiring me to wait a moment, they brought me an ample quantity of bad barley couscous, with a small bit of beef. I afterwards went to sleep under the roof of the mosque, among the Moors, who were necessitated like myself to take refuge there. As the sons of Haggi-Le Mekke had represented to me, no stranger is here admitted into the interior of the houses, lest the women, who are not allowed to see any other men but those of their family, might be exposed to indiscreet observation : consequently travellers obtain an asylum for the night in the mosques, and 
the host at whose house they alight sends them their meals; they send for them at supper time, but receive them in a very dark corridor.

At eight o'clock in the morning, I went to my host's for my breakfast, and seated myself, as on the preceding afternoon, at the door, waiting for an invitation. The youngest son of the family soon came, and inquired very kindly if $\mathbf{I}$ had breakfasted; on my answering in the negative, he ordered a slave to bring me some dates and gruel made of barley-meal : this gruel is very thin, and serves for a beverage in eating the fruit; with bread or couscous they drink nothing but water. With a stomach thus slightly supported the stranger is obliged to await the hour of supper, when a little couscous is given him; this is the nourishment they provide for those who ask hospitality of them, and for their slaves. The masters drink with their breakfast a very thin gruel made of wheat flour, and dine upon new bread and the fruits of the season; they have abundance of fine melons, of which they are very fond; and the richer inhabitants of Tafilet breakfast upon tea with bread and figs. At ten at night, the usual hour of supper, they eat couscous made of wheat flour, dressed with mutton or poultry, for they rear some domestic fowls.

While sitting at the corner of a street I made acquaintance with a Moor, named Sidi-Baubacar; who put some questions to me very prudently, and appeared to interest himself in my situation; he is a very mild and good man. He had travelled to Cape Mogador and to Morocco, and in the former town had had much intercourse with the christians, whom, in common with all other Moors, he detested. He shewed some taste for the sciences and was desirous of instruction, had learned arithmetic, and was well acquainted with its first three rules, in which he could prove his calculations. He was in the habit of writing upon a slate, which he brought to me, and we made some calculations together.

vol. II. 
This man was somewhat of an enthusiast, and conceived a friendship for me; he spoke much of the knowledge of the Europeans, which he considered as vastly superior to that of the Moors, and shewed me a watch to which he attached much value, because he was the only person in the country who had one. It was at his house that I saw the English pocket compass, which I formerly mentioned. He talked of Bonaparte and his campaigns in Egypt, asked if it was during his residence among the Musulmans that I was made prisoner, and said that he was at Tripoli about that time; finally he inquired my age ; as I was covered with rags, was ill, and my complexion scorched almost to blackness by the heat of the sun, I appeared older than I really was; he had therefore no difficulty in believing that I was thirty-four years of age.

On the 26th, I proposed to a poor Jew named Jacob, to purchase of me a shilling by weight, because, as this coin was not current in the country, and he was a smith and a worker in gold and silver, he could turn it to account in his trade. He required me, for this purpose, to come to his house, to satisfy his curiosity no doubt; however the proposal also answered mine, for I knew not by what method to obtain admission to the interior of even one house. I entered then the humble dwelling of this Jew; who conducted me through two small low rooms, very dark and exceedingly dirty, into a third, somewhat larger, which received light and air only by a small opening in the roof : this opening is common to all the apartments in the interior of the house, the dwellings of the Jews being as simply constructed as those of the Moors.

Jacob, who did not possess a mat, was obliged to seat me upon the ground. He opened a closet, and fetched some nuts which he presented to me, adding a fine slice of melon and a large piece of wheaten bread, of the preceding day's baking. His wife and aged mother, seated beside me, exa- 
mined me with insatiable curiosity; they appeared mild and timid, but nevertheless, addressed several questions to me relative to the countries inhabited by the christians. I observed in this room two large sacks of corn for the family provision, some fowls, and a dog, the guard of the house : in one corner was collected the dirt of several days' sweeping. After partaking of the Jew's hospitable collation I took leave of these good people. A negro slave had accompanied me, fearing, he said, lest these infidels should insult me. Jacob desired me to return on the following day, when he would change my piece of money; for, my visit having been made on Saturday, no business could be transacted. The Moors, inquisitive and troublesome, were far less generous; they offered me nothing but their bad dates, and even of these they were liberal only because they could not themselves consume their superfluity.

On the 27 th, I accompanied Sidi-Boubacar to a market, which is held three times a week near a village called Boheim about three miles N. of Ghourland: Boubacar mounted a fine mule, and myself an ass, destined to carry the provisions on our return.

This market is held in a beautiful spot surrounded by palm-trees; it contains many clay huts for the accommodation of the dealers in stuffs, mercery, and spices, and the butchers. 'The Berbers and Arabs from the adjacent villages come hither to sell their merchandise : they bring cattle, corn, fruit, and green vegetables, and in return purchase the stuffs of the merchants. As I expressed a desire to take a particular survey of the market, my companion ordered one of his people to attend me, assuring me, that if, as a stranger, I was found there alone, the very clothes I had on would be stolen. I was astonished at the variety of articles exhibited in this market. I saw there great abundance of fine herbs, cabbages, turnips, onions, peas, and dried beans, indigenous fruits, such as raisins, white and black currants, pears, nuts 
gourds, and melons of a fine sort; green lucern for the horses, and many productions of Europe; also fowls and, boiled eggs ; I bought half a dozen of the latter for the value of six farthings of our money. I observed sheep of an astonishing size, covered with very fine white wool.

Water sellers, with their full bottles, walked to and fro in the market, with a little bell to give notice to all who wished to drink, for the heat here is most oppressive. There is no scarcity of wells in the market, but they are very deep, and as strangers have not ropes to reach them, much water is sold, though it is rather brackish. I beheld asses and mules laden with the productions of nature and industry arriving. from all quarters, and might easily have fancied myself transported into a well stocked European market. I bought some figs and raisins for my refreshment, together with a small wheaten loaf worth a sous. The Jews are the principal brokers: there are merchants established here who purchase from individuals the woollen goods manufactured at home, store them, and export them to other markets. No money is current here, except that of Morocco and Spain; the coin of other European countries is taken by weight. After traversing the great desert, almost deprived of the necessaries of life, the pleasure which I experienced in contemplating a market so richly furnished is indescribable, but I was obliged to return to the village with the slave to whose care Sidi-Boubacar had consigned me, and this man, when his purchases were completed, was unwilling to stay any longer.

On the 28th, Sidi-Boubacar, who was become much attached to me, sent me an invitation to his house, where he waited to receive me. He seated me on a fine carpet, spread in the court, under a little shed, and then requesting me to wait a moment, he went for a friend of his, a Moor of distinction. Soon afterwards a slave brought, upon a very clear copper waiter, a meat pasty fried in butter, and a fine slice of melon, bought on the preceding day at the market of Boheim : Sidi- 
Boubacar broke the pasty and his friend and I as well as himself did justice to it. In the evening Jacob the Jew changed my shilling, which enabled me on the succeeding days to buy a little bread. The same day, being at the mosque, a Moor, whose father was recently dead, accosted me, and, slipping an eightpenny piece into the pocket of my coussabe, begged me to accept it for the love of God and the Prophet.

On the 29th, Haggi-Le-Mekke gave me notice that I must hold myself in readiness to set out for Fez. Unable, from the state of my health, to undertake so long a journey on foot, I made inquiries concerning the means of riding; I was in fact swelled and weak. I was asked if I had dragmes sufficient to pay for a mule : I could have done so, but thinking it not prudent to confess it, I preferred pleading poverty, and hoped that the sale of my two blue pagnes of Soudan would produce enough. Three days previously I had confided them to a son of my host's for the purpose of sale, but I was now advised to carry them to the market of Boheim, whence the caravan was to set out; I repaired thither with the intention of seeing the bacha or governor, to ask assistance from him.

On quitting Ghourland, I was accompanied by a muleteer mounted upon an ass; this man was charged by Haggi-Le-Mekke to conduct me to Sidi-Habib-Benani, who resided at Boheim and was chief of the caravan going to Fez, to whom he gave me particular recommendations. On the road I was stopped by the Berbers going to the market, who, perceiving that I was a stranger, surrounded me to the number of twenty or thirty, saying all together, "Who are you? Whither are you going?" They all pulled me by my dress and gave me no time to answer : at length they carried off my pagne and would have stolen my bag also, had I not on setting out intrusted it to my guide, who, mounted upon an ass, with a Berber behind him, had gone on before me, without troubling himself whether I was able to follow or not. The thieves, not content with my pagne, were about to take 
my coussabe also, when Haggi-Lemedan, (my guide,) to whom the Moors of his acquaintance had given notice of my situation, returned at full gallop with his Berber; and the latter made the plunderers restore all they had stolen from me. Soon after this vexatious accident, we reached the market, which I found as well supplied as the first time I visited it. On the road I had met two mounted Berbers pursuing at full speed, with loaded guns, two Arab horsemen, who were galloping off with the utmost precipitation. When the market was over, I went, accompanied by my guide, to Sidi-Habib-Benani's, who sent me to take a lodging in the loft of the mosque; about ten in the evening he supplied me with a very good couscous.

On the morning of the 3oth of July, I seated myself modestly on the ground at my host's door, being well aware that he would not have the complaisance to send my breakfast to this public lodging; as soon as he perceived me at prayers with my chaplet in my hand, he sent me some wheaten gruel but without dates. At ten o'clock, I requested a Moor to conduct me to the residence of Sidi-Habib-Bacha, at the small town of Ressant, two gun-shots north of Boheim. This man obligingly complied, and we set out; but we learned on arrival that the Bacha, who was indisposed, would not come thither that day, and that he seemed to intend spending it at his private house at Sosso, a village situated about a mile and a half S. E. of Boheim. As I expressed a strong desire to repair thither, my honest Moor procured a man of the village, in the service of the Bacha, to accompany me to the latter. On my arrival I was conducted through a large court, tolerably clean, into another and smaller one, at the gate of which two sentinels were sitting upon the ground, with their muskets resting against a wall. My arrival was announced to the Bacha, who gave orders for my being shewn in. I found this Arab grandee seated, without ostentation, on a mat, upon the ground, under a shed, near the wells, 
which diffused a pleasant coolness. There were two Moors in attendance, playing as it were, the part of courtiers. The Bacha gave me a favourable reception and inquired the cause which had brought me into his presence. I shortly recapitulated to him the various circumstances which had occasioned me to take so long and arduous a journey across the Soudan and the desert; informing him that I was from Alexandria, whither I was anxious to return, but that from poverty I had no means of conveyance thither; and being in.ill-health in consequence of the fatigues, which I had undergone, I could not travel so great a distance on foot. Amongst the numerous questions which he put to me, he as ked how I had defrayed the expenses of my route since $I$ had quitted the negro countries: to which I replied, flattering Musulman generosity, that every one had contributed a small donation to the relief of my wants. He afterwards turned the conversation to the Europeans, ridiculing their faith. One of his Moors, a very corpulent man, hereupon sneeringly observed, "Why, as Jesus is the Son of God, did he suffer himself to be crtscified by the Jews?" As this question was pointed at me, I replied, that I was in no way concerned to support a cause the merits of which I did not understand, and that the Christians must discuss his objection. The Bacha then sent for his steward and commanded him to give me some dates, which were brought in a small straw basket, but of which I declined eating though I was politely pressed. By order of this chief, I was reconducted by one of his sentinels to my host at Boheim, with an invitation to repeat my visit on the following day at his government residence; he also sent instructions to Sidi-Mohammed, the sherif who had accompanied me in the morning, to repair thither with me.

On the morning of the 31 st, I did not fail to wait with the sherif for the Bacha, on his road to the town. We stood up immediately upon perceiving him. He rode a fine grey horse, and was escorted by two soldiers, each armed 
with a musket. He halted for a moment before us : the sherif, in accosting him, respectfully kissed his white tunic; the Bacha spoke a few words to him in a low tone, after which, raising his voice a little, he informed me that I must remain at Ghourland till further orders, I readily concluded that I had nothing to hope from his highness; and, returning to my village, Mohammed confirmed me in my opinion. Sidi-Habib-Benani had set out in the morning for $\mathrm{Fez}$; having refused to give me a mule or any other conveyance for three mitkhals of silver, the produce of the sale of my two pagnes: thus $\mathbf{I}$ found myself at Boheim, without knowing how to leave it. I had a very good coussabe, which Abdallah-Chebir had given me at Timbuctoo; and I determined, at the risk of going away without clothing, to sell it in the market, and endeavour to hire an ass, so that I might be able to set out the day after the morrow with a caravan going to $\mathrm{Fez}$ : the eldest son of Benani, a merchant by profession, sold my coussabe for two mitkhals, which, with the three others, sufficed to hire an ass. At ten at night, I went as usual to present myself at the gate of my host's son, from whom, during the day, I had received as a present some bread and a bunch of grapes : he also sent me a supper and $I$ went to bed under the sacred roof of the mosque. The court of this structure was locked and the inmates could not open it during the night; a circumstance which had nearly drawn me into grievous trouble. This court enclosed the tomb of a holy sherif, long since deceased : the following morning, my fellow-lodgers were scandalized to perceive that this revered sepulchre had been soiled during the night; a universal cry of indignation arose, and all eyes were turned upon me. Amazed and confounded, I had not courage to assert my innocence; my only excuse was ignorance of the localities, and I protested, with perfect truth, that the profanation was not wilful but purely accidental. This sincere allegation was, however, 
far from calming the tumult, and I know not how serious the consequences might have been, had not some old men fortunately determined to intercede in my favour. They represented that my situation as a stranger should be taken into consideration; that $I$ was undoubtedly ignorant of the existence of a tomb in this place; but that, supposing me even acquainted with the fact, it was impossible I could have learned amongst christians to respect that which is the object of homage to all good Musulmans; that some indulgence should, therefore, be shewn to my want of knowledge. This plea made an impression and the matter dropped.

On the Ist of August, I repaired in the morning to the gate of my host to seek my breakfast; but I waited till two in the afternoon without obtaining any thing. At this time several Moors were collected and beginning to question me; but I told them that I was suffering too much from hunger to be in a condition to answer them, having eaten nothing the whole day. A zealous Musulman offered to give me a loaf for the love of God, if I would accept it ; and I was too much famished to refuse it, hard as it was.

On the 2nd, the caravan prepared to depart for $\mathrm{Fez}$; the man whose ass $I$ had hired had received my earnest, and I waited for him in the village where he had engaged to take me up. Before taking leave of this country I will give a succinct description of it. 


\section{CHAPTER XXVI.}

Description of Tafilet and its commerce.-Flourishing state of agriculture and industry.-Miserable condition of the Jews; their habits and customs.-Afilé.-Gardens.-Tanneyara, Marca, M'Dayara, Rahaba.Chains of granite mountains.- Small river of Guigo.-L'Eyarac, Tamaroc, Kars, Ain-Zeland, L'Eksebi.-Very high mountains covered with cork-trees.-L'Quin.-Guigo.-Town of Soforo.-Town of el$\mathrm{Fez}$, or Fez, the ancient capital of Morocco.

The Tafilet is a small district forming, like el-Drah, part of the dominions of the Emperor of Morocco. Its inhabitants pay some imposts to this monarch, who maintains a bacha or governor, resident at Ressant, a town distinguished by a magnificent gateway, surrounded with various coloured Dutch tiles, symmetrically arranged in a diamond pattern.

The villages of Ghourland, L'Eksebi, Sosso, and Boheim, in the same line, all S. E. of Ressant, are pretty near each other: those which I have had an opportunity of examining, are nearly of equal size, and contain about eleven or twelve hundred inhabitants, all land-holders or merchants. The soil of Tafilet is level, composed of sand of an ash grey, and very productive; much corn, and all sorts of European fruits and vegetables, are cultivated here; lucern thrives well, and when dry is stored for winter provender.

The natives have fine sheep, with remarkably white wool; they use it in making very handsome wrappers, which are woven by the women. They have also some horned cattle, though fewer than the roving tribes, excellent horses, some asses, and many good mules. The horses are for the most part the property of the Berbers, who are very numerously established in Tafilet, but less addicted to 
pillage than those of el-Drah, and indeed formidable to strangers alone.

This country is in general very agreeable : its inhabitants carry on a considerable commerce with the Soudan and el-Arawan, whither they export tobacco in leaves of their own growing, together with European commodities; and receive in exchange gold, ivory, gum, ostrich-feathers, dried provisions, and slaves; for, unhappily, the infamous traffic in the latter exists in full vigour in this part of Africa. The commodities which the merchants dispatch to Timbuctoo, through the medium of the roving Moors of el-Harib, who may be considered as the carriers of the Soudan, are transported on camels to the confines of the desert by the Berbers, who deliver them to the Moors engaged to convey them to their destination. The Berbers receive a tribute for this service, a species of indemnity given to them by agreement, since they do not, like the Arabs, extend their travels through all the negro countries. If the merchants were to neglect this prudent precaution, their caravans would be pillaged by these barbarians, as they sometimes are by the Touariks. I have already said that the most distinguished Moors of Tafilet usually settle at Timbuctoo, in the hope of making a fortune, as amongst us Europe is left for the new world : these Moors, after devoting five or six years to commerce, purchase gold and slaves, and return to live peaceably in their own country.

The soil of Tafilet is very good, and produces all the necessaries of life. The numberless date-trees surrounding each property furnish their owners with a plentiful subsistence and a considerable branch of commerce. They sell a quantity of dates in all the dependencies of Morocco, and especially in the towns situated on the sea-coast.

The population of this district is divided into several classes, and the distinction of social ranks is rigorously observed. Labourers by the day or month are considered as 
belonging to the lowest grade; those who esteem themselves of a higher order treat them as a very inferior race of beings. There are also in Tafilet many negro slaves, and some emancipated negroes, who, however, are never suffered to intermarry with the Moors; even the children born of a negress and a Moor, by a clandestine union, have no acknowledged condition in the country, and can never emerge from the lowest classes.

The inhabitants of Tafilet tan a great quantity of leather; they make excellent morocco, which is much esteemed in commerce, and finds at $\mathrm{Fez}$ a ready market. The people of this country are more industrious than I have any where remarked, in the different parts of Africa which I have visited.

Every one brings to the market the fruit of his labour; there may be seen in abundance woollen wrappers, coussabes, tanned leather, pagnes, shoes, mats, wooden trenchers, in short all the manufactures of the country.

Each proprietor is accustomed to enclose his lands either with an earth wall or a ditch; all the villages are walled, and those I have seen have but one gate of entrance, which is shut every evening. The inhabitants rear much poultry, as large as ours, and eat the eggs boiled. They have pigeons, but these birds are scarce. Some individuals keep a dog and a cat, which live upon dates.

Throughout the districts of el-Drah and Tafilet are found Jews, who inhabit the same villages with the Musulmans; they are in a pitiable condition, wandering about almost naked, and continually insulted by the Moors; these fanatics even beat them shamefully, and throw stones at them as at dogs: the smallest children may abuse them with impunity, since they dare not revenge themselves, and cannot expect protection from authority. I have frequently been so excited myself as to threaten these little revilers with severe chastisement. 
The Jews of Tafilet are excessively dirty, and always go barefoot, perhaps to avoid the inconvenience of frequently taking off their sandals, which they are compelled to do in passing before a mosque or the door of a sherif. They are clothed in a shabby coussabe, and a very dirty white cloak, of little more value, which passes under the left arm, and is fastened over the right shoulder. They shave their heads after the example of the Moors, but leave a tuft of hair which falls over the forehead. Some are pedlars, others artizans; they manufacture shoes and mats from palmleaves; some of them also are blacksmiths. They lend their money upon usury to the merchants trading in the Soudan, whither they never go themselves. Their only visible fortune consists in their houses, but they often take lands as a guarantee for the money which they lend. Money is always plentiful with the Jews : yet they affect the utmost poverty; because the Moors, who ascribe to them greater riches than they really possess, often persecute them for the purpose of extorting their gold: besides which, they not only pay tribute to the emperor and his agents, but are moreover harassed by the Berbers.

The Jews live better than the Mahometans, couscous and gruel forming but a small portion of their food; their bread is of wheat, kneaded and baked by themselves and their principal bererage, beer of their own brewing, though in the season of the vintage they make a little wine.

The Jewish, as well as Moorish women, wear a piece of stuff, twelve or fourteen feet long, about the body and thrown over the head, and go barefoot; their costume indeed differs only in the head-dress. They have on each side of the head a thick large tuft of hair hanging over the shoulder, about five inches in length and three in circumference, and they habitually cover their heads with a piece of coloured stuff, always dirty, like the rest of their garments.

The Jewesses whom $I$ have seen in Tafilet are in general 
small, lively, and pretty : they have blue eyes, animated and expressive, aquiline nose, and a mouth of middling size; they are inquisitive, and very fond of talking. Drawing water, washing linen, fetching wood for cooking, in short all the household labours, fall to their share.

I shall not undertake to portray the Musulman women of Tafilet; 1 found it impossible to obtain a view of their faces: when out of doors they have the appearance of an uncouth moving mass, from an enormous woollen cloak, in which they are enveloped from head to foot, and which scarcely allows them to see the way they are going: it is only in the bosom of their families, and sometimes in the inner court, that they shew themselves unveiled. Care is taken to give the women notice to retire to their private apartments, when strangers are about to enter the dwelling upon any business.

A custom prevalent in the east obtains also here and is rigorously observed: when a common Moor passes a sherif he unties his sandals, takes them in his hand, and makes a low and respectful obeisance.

On the 2nd of August, about half past four. P. M. the caravan proceeded in a N. N. E. direction. We met on the road a vast number of Moors from the country, driving asses loaded with all sorts of productions, as melons, grapes, figs, and other fruit, and vegetables, going to a neighbouring market.

We crossed some fields, and passed near a walled village the name of which I have forgotten: continuing our route for the space of a mile to the N. N. E., we arrived at the village of Afile, without which we halted at sun-set. It is situated near a considerable rivulet, called by the natives Sidi-Aiche, the water of which although brackish, is their only beverage: this rivulet runs slowly to the $N$. W. Plenty of barley for our beasts was brought, soon after our arrival, and some water-melons for the refreshment of the 
sherifs, of whom we had half a dozen in the caravan travelling to Fez to sell their dates; and who were not prevented by the insignificance of their traffic from assuming airs of importance.

Towards eleven at night, several large calabashes full of couscous, with the flesh of a kid killed for the purpose, were brought to us from the village; the bearers carried them on their heads, and were lighted by a taper. No sooner had these messes arrived than the descendants of Mahomet feasted voraciously, and gave what remained to the Moors of their train : care was taken to awaken all who were or pretended to be asleep. I was at the moment lying on the sand beside the baggage ; and as no one seemed to pay any attention to me, I patiently resigned myself to the loss of my supper, although I had eaten nothing the whole day but some dates, given to me by my host at parting. At length a Moor from the village, walking about with his taper in his hand, discovered me, and asking who I was, led me to an immense dish of couscous, round which several Moors were assembled, and desired me to help myself. The Moor who presided at the repast placed some scraps of meat upon an old mule-cloth, and, when we had eaten the couscous, he gave to each a little bit of the reserved meat, tearing it with his dirty fingers.

On the 3rd of August, at half-past five in the morning, we again proceeded northward, through plantations entirely surrounded with earth walls, over which I perceived beautiful fruit trees, such as pears, figs, apricots, vines, and some rose bushes. These charming plains though rather deficient in moisture, often renewed the delightful remembrance of our European gardens. The sterility of the Sahara was still so impressed upon my imagination, that the plains of Tafilet appeared by comparison a terrestrial paradise.

About ten in the morning we passed Tanneyara, a little village, a mile to the east of our road, shaded by immense 
numbers of date-trees. Here our caravan was retarded by a troop of Arabs, to whom we were obliged, whether we would or not, to pay the passage-dues. This prank occasioned a great deal of confusion; the two parties had nearly come to blows; but fortunately no bad consequences ensued: the merchants gave a few dragmes, and the Arabs left us to continue our route, which lay over a dry and gravelly soil. The gently swelling hills which rose on either hand were apparently composed of red sand, and bore no vegetation : the heat was extreme, and we had no water to moisten our parched lips. At one in the afternoon we reached Marca, a large village enclosed by a wall twelve or fourteen feet high, and there halted.

We ran in haste to the wells, situated beyond the village, but could not draw water enough, having unfortunately no better bucket than an old leathern bag full of holes. My thirst being at length satisfied, I seated myself in the shade near the gate of the village; where many idle Moors were lying on their backs, waiting the call to supper : immediately upon perceiving me they rose with astonishment and asked each other, "Who is this man ?" easily detecting me for a stranger by the costume I always wore, which was of Soudan stuff, and strikingly different from their own.

They assembled round me and overwhelmed me with questions. I was never taken at first sight by the Moors of Tafilet for an Arab; they always treated me at once as a stranger; redoubled artifice was necessary to deceive them : but when I declared myself to have been taken prisoner while very young by the army of Bonaparte, they appeared satisfied, and congratulated me upon the good resolution I had formed of returning to my country.

At the gate of Marca, I met, by a singular accident, a Berber whom I had known at el-Harib : he received me with kindness, and immediately acquainted the assembly with my history. This Berber politely invited me to visit 
his humble cabin, of a single floor, where he seated me on a very clean mat, and his wife produced some dates which we ate together. She sat unveiled in a corner of a dark and dirty room employed in weaving a woollen wrapper. When we had eaten our dates, the Berber led me to the mosque, and introduced me to two sherifs, natural sons of the emperor: we found them at prayers: but no sooner had they finished than I was persecuted with questions; amongst others whether I had been circumcised either in the Soudan or at Alexandria: I replied that I was circumcised in my infancy previously to leaving my country, and I hastened to change the topic, these interrogatories being always distressing to me since they constrained me to repeated falsehoods. Fortunately my reply appeared satisfactory, and I took advantage of their discourse being directed for a moment to their pupils to leave them; they soon, however, sought me out at the gate of the village, where I was seated, placed themselves on the ground beside me, and displaying a New Testament in Latin and Arabic, asked me if I knew that book; I read a few passages to them, and they amused themselves with ridiculing the supposed credulity of the christians.

As the village was surrounded by pleasant walled gardens, I expressed a wish to see them. 'The youngest of the party instantly took me by the haud, and, followed by six other Moors, we walked to them. The young sherif when in his garden ordered some figs and grapes to be gathered, which he offered me very gracefully. I was particularly surprized by an almost French politeness in his manners; for example, never serving himself first, offering me the finest and ripest fruits, and even peeling them for me. I ate however but sparingly of fruit, fearing lest it might disagree with me. I saw in this garden melons, gombos, and a great variety of fruit-trees; it also contains a well thirty feet deep.

vOL. If. 
From the garden we returned to the mosque, where Sidi-Abdoul-Rahman, (this was the name of the young sherif) ordered one of his people to carry me some bread and honey; and desired me to remain till supper time, as he intended to provide me with that meal.

This good young man, about twenty-two years of age, favoured me with a very obliging invitation to spend some days with him at Marca, in order to recover from my fatigués, promising afterwards to forward me to $\mathrm{Fez}$ at his own expense. I thanked him heartily, but urged as an objection my impatience to reach home. The Berber brought me a handsome dish of mutton couscous; and a moment afterwards the sherif sent me a portion of his supper, and had the further kindness to order one of his household to accompany me with a lantern to our encampment.

On the $4 \mathrm{th}$, at half after five in the morning, we departed, journeying N. N. W., amongst mountains and along the banks of a beautiful rivulet which fertilizes the neighbouring soil : the resident proprietors understand how to avail themselves of this resource; they form canals from it, by which they water their small possessions; by this method they are enabled to cultivate corn and maize in seasons of the greatest drought, and to produce abundance of fine melons. Some palms and fig-trees grow on the margin of this pretty rivulet; and I remarked throughout the route small habitations scattered at very small distances. We advanced more than two miles an hour notwithstanding the stony nature of the soil. At half past two P. M. we halted at M-Dayara, a town defended by a high wall and encompassed by a moat seven or eight feet in depth and of equal breadth. We entered by a large gate and passed the night here. When the cattle were unladen and the baggage arranged, my guide, the sherif, noble scion of the prophet, recommended me to repair to the mosque to seek my supper : without answering him, I remained some time seated 
upon a mat, near a Moor of the town, who seeing $I$ was in no hurry to withdraw, and no doubt fearing the necessity of dividing his supper with me, advised me to rejoin my companions, and take my share of the provision which the town would provide for them. Thus repulsed on all sides I lay down beside the baggage: my illustrious muleteer angrily asked, why $I$ did not remain at the mosque; to which I replied that he might go thither himself to seek his supper; this answer silenced him. Finding him so desirous to get rid of me, I thought that the Moors of the caravan intended to club together to purchase food, and determined to learn how this might be.

The sherif Sidi-Moula-Sitec, a man of high nobility and who enjoyed the imperial favour, travelled along with our caravan; he carried his wife with him, concealed under a scarlet pavilion, as well to preserve her from the intense heat as to screen her from our observation : at the haltingplaces, four persons assisted her to alight, and one of her women, who also appeared veiled in our presence, lifted up a corner of the curtain to admit the air.

Sidi-Moula-Sitec, whose provisions for himself and his suite were separately dressed, sent in the evening a copious supply of tea to his travelling companions; they took it while waiting the approach of supper time; and soon afterwards an enormous dish of couscous was sent to them, which was speedily divided among twelve or fourteen Moors, who disputed the possession of it. When my muleteer had satisfied his hunger, he put the two or three mouthfuls of couscous that remained, in a small basket, generally used for feeding his asses with barley, and brought it to me, I eagerly accepted this food, as I had eaten nothing all day but a few dates. After this slender repast, finding that I should not be permitted to remain beside the baggage, I went in search of a place where $I$ might sleep in quiet, and lay down at the door of the mosque, near some travel- 
ling Moors, who were so much annoyed by my cough, for I had a severe cold, that in great anger they even struck me, to compel me to withdraw.

At five in the morning, I perceived by the arrangements which were making, that we should not set out before evening, and determined, though with repugnance, to beg in the town for some dates, a fruit so plentiful in this country. I first applied to an old Moor, who affected all the externals of devotion, but he shewed little sensibility for my misery, recommending me to trust in God who would assist me; a second brought me a handful of rotten dates, which I could not eat; and a third, whose mien announced more charity, gave me a considerable quantity, but they were harder and worse than those which I had eaten at el-Harib. Losing my fortitude, and undeceived on the subject of Musulman charity, so much vaunted among us, I returned to our baggage, and, presenting my acquisition of fruit to the asses which refused it, I breakfasted upon a handful of that which had been given me at Boheim. Part of the day was spent in shoeing the animals.

About three P.M, being all ready, we took our departure, and travelled N. W., over level and stony ground; the sun was setting as we reached Rahaba, where we encamped under the palm-trees, without the town. As I happened to be placed near the sherif Sidi-Moula-Sitec, who had shewn me, on the road, the unexampled courtesy of giving me a draught from the cup which he himself in general used, I went to thank him ; he gave me a friendly reception, and, offering me his hand with a smile, told me that he had directed one of his suite to supply me with provisions all the way to $\mathrm{Fez}$, and, to leave me under no uneasiness on this head, he renewed his order in my presence; but the profligate servant took little notice, and obeyed his master's command for one night only.

On the 6th of August, at five in the morning, we continued our route northward, at first on very level ground; 
after which we reached a chain of mountains, stretching from E. N. E. to W. S. W., and struck into its gorges, following the course of a pretty little rivulet called Guigo; the road being extremely stony and difficult. About eight we passed L-Eyara, a village containing from twenty five to thirty houses, all ill-constructed with a ground-floor only; this village stands on a rock of black granite. Hitherto our direction was N. N. E., here we turned due north.

At one P. M. we halted at Tamaroc till the heat, which was intense, should abate : I lay down upon the grass, in the shade of a fine rose-laurel, pleasantly situated on the margin of the rivulet, the freshness and gentle murmurs of which inclined me to sleep. The hills on each side of the route had no great elevation, and appeared composed of a brittle and coarse-grained rose-coloured granite, in some parts combined with white quartz. At three P. M., the heat having somewhat moderated, we proceeded northwards through the defiles till half past five; we then turned to the west, still following the sinuosities of the same rivulet. This stony road led us into a valley, well cropped with corn and maize, the verdant aspect of which amidst these barren mountains presented an enchanting spectacle. About seven in the evening we halted at Kars, where we passed the night. Between Tamaroc and this place,we saw no more palm-trees.

On the 7 th at five A. M., we resumed our journey, first in a westerly, and subsequently in a northerly direction, still threading the defiles of the mountains, through a less fertile tract than that over which we had just passed; here though the country is still watered by the Guigo it is generally barren.

The roving Berbers, who encamp in these narrow valleys, find here and there a little forage for their cattle. About eleven o'clock we arrived at N-Zéland (or Ain-Zéland) our beasts being much fatigued. The hamlet is inhabited by Berbers, who breed fine sheep. As these people are ac- 
customed to give nothing to the Moors, part of our caravan were compelled to forego their supper. The sherif Sidi-Moula-Sitec ordered a couscous, and sent a portion of it to the sherifs of the company; the Moors of inferior rank were not included in the distribution.

The Berbers, thinking to gain something by us, made cakes of barley-meal, which they sold for a good profit to those who had money: encouraged by the success of this traffic, they killed two sheep, which they cooked whole at a large fire, cut up into small pieces, and sold for four mouganans, a sum equivalent to eight sous of onr money. But our company was so numerous that this provision proved insufficient, and those who could not obtain any ate dates only; a poor substitute for more nourishing food.

On the 8th of August, at three A. M., we quitted $\mathbf{N}$-Zeland. The beast I rode being excessively fatiguied, I was compelled to perform part of this day's journey on foot; and still weak, I walked with difficulty over the flinty mountain roads, pausing every moment to recover breath. 'I was not singular in my misfortune, many of our people were on foot, for the poor animals could scarcely drag themselves along. 'Till eight o'clock we proceeded northward, then for one hour westward, and afterwards turned again to the north. The road was so bad that the asses sunk under their burdens; their haunches were galled by the friction of a girth, which it is customary here to pass over the rump in the fashion of a crupper, to prevent the load from slipping forward in descending steep declivities, while another, which girds the breast, performs the same service in ascending. The guides without any remorse struck these poor animals severe blows to quicken their pace. At two P. M., overcome with fatigue, we reached L-Eksebi, where we halted: this pretty village is encompassed by a good wall, and contains about eight hundred inhabitants; it is situated on an extensive plain, watered by the windings of the rivulet 
which I have before mentioned, and surrounded by high mountains wholly destitute of vegetation. The plain is well cultivated, and even embellished by some olive-trees. On our arrival, the inhabitants, all Moors, opened a market, where we found in abundance bread, meat, raisins, and figs, which were all sold by weight. Near this market is a kind of caravansera, where travellers are received on payment of a small remuneration for the animals only; these are lodged in little galleries constructed for the purpose, and the men sleep near them on the ground.

As the dates presented to me by my host of Boheim were now exhausted, and I had nothing whatever to eat, I determined to beg some, not of the towns-people, for as the palm-trees do not grow in the vicinity they are dear here, but of a young Moor of our own caravan, who obligingly gave me some.

On the 9 th, we set out at five in the morning, directing our route to the north; about seven we turned to the W. N. W. ascending hills from one hundred to one hundred and twenty-five feet above the surface of the plain. In every direction similar eminences meet the eye, all exhibiting, with the exception of a few cork-trees, complete sterility. Exhausted with fatigue, I feared that it would be impossible to continue my journey; my limbs bent under me, and I was compelled to sit down continually; my courage was ready to forsake me: this ascent was indeed a terrible task for my enfeebled powers. $B_{y}$ the blessing of God we attained the summit by nine o'clock; and thence descended into an extensive and beautiful plain, surrounded by high lands, which were mostly barren of vegetation. Four times in the course of the day our caravan was stopped by the Arabs, who had encamped by the road-side, to obtain payment of the passage dues, which was made in dates, and bread baked a second time in the oven; I was told that they acted under the sultan's orders. Some Berbers as we passed spread a pagne 
beside the road, that a few dates might be thrown to them : this fruit is scarce and dear in this part of the country; and some of them brought us water in exchange. About three o'clock we arrived at L-Guim, a small Moorish village, where some cultivation is visible and some forage may be obtained, but the general aspect of the country is sterile and dry; not a single tree is to be seen. I supped upon some pieces of barley bread, baked a second time, and which I steeped in a little water. This bread Sidi-Moula-Sitec had sent me as a present, the evening before, by one of his servants. After this repast I lay down near a field of maize, making my pillow upon a ridge between its furrows.

At five in the morning of the 1oth, we set out again, our route lying W.N.W.; at seven we turned to the north through defiles of arid and stony mountains; at ten to the N.N.W. The landscape, interspersed with lofty eminences, has a most dreary appearance ; on some of them only grows a quantity of box to the height of about eighteen inches, the leaves of which were dry and yellow. In the level parts we saw some Arab tents from which at our approach the children issued to beg dates. About three P. M. we reached Guigo, a small Berber village : its environs are naked, without any trace of cultivation, and the wells are so distant, that it is not easy to procure water without paying in dates, of which I had no more, and was obliged to have recourse to charity for a draught; I applied to several Moors, who all repulsed me like a dog, and bade me slake my thirst at the fountain.

The heat, which had been intense, moderated towards evening ; just before our arrival a slight thunder-shower fell, which continued for a quarter of an hour, and greatly cooled the atmosphere. A sherif, who had long suffered from a bad foot, gave me some water and a small cake of wheat and aniseed, on condition that I should furnish him with a remedy; I had still a little diachylon left, and divided it with him; he then opened before me several rags, in which his 
foot was wrapped, and I saw two large white maggots upon the nearly healed wound.

On the 11th, at three A. M. we quitted Guigo, journeying north upon a very stony road : many shrubs, however, flourish in this country; wild roses and mulberry-trees, the hawthorn, olive-tree, dwarf oak, and others, are watered by the current of a meandering rivulet,* in the transparent and delicious waters of which we found relief from our thirst. About two P. M. we arrived at Soforo, a walled town, situated in a fine and extensive plain, very stony but fertile; maize and the olive are cultivated in this tract. The approach to the town is ornamented by pretty gardens enclosed by quickset hedges, and abounding in fruit-trees, round which creep in great numbers vines loaded with fine grapes. We alighted at a fandac. $\uparrow$ I walked through this town which is the finest that I had hitherto seen. It contains a handsome mosque, built of brick and plastered with mortar; two fountains appropriated to the purpose of the Mahometan ablutions conduce to its decoration. Two watermills are the most remarkable objects in Soforo. The houses are chiefly built of brick and of one story. The streets are narrow and dirty, nevertheless the vicinity of several brooks which rise in the mountains, and the many pretty gardens of the suburbs render this town an agreeable abode. A market is held here daily, which attracts many strangers, and in which the Jews have shops. Baked meat is sold in it, and remarkably fine melons. A clumsy clock in the mosque tower excited my surprise.

In the evening, Moula-Sitec employed a Jew merchant to purchase some wax candles for him; the poor Jew on his return was stopped by a sherif, who, detaining him by his cloak, demanded one of them. In vain he protested with an

* The Guigo without doubt.

$\uparrow$ A kind of inn. 
air of supplication, that he had no means of making such a present, the Moor vehemently insisted, and, seizing the Israelite by a lock of his hair, drew his poniard with an apparent intention of killing him; quaking with fear the poor wretch cried out with all his might, "Oh! spare me, my lord, for the love of God." The Moor at length released him, and the Jew ran off at his utmost speed.

Moula-Sitec called me to his presence, and inquired, as though he doubted my sincerity, whether I loved the Musulmans; he then made me recite some verses of the Koran, and at length informed me that on the following day we should reach $\mathrm{Fez}$, which town is sometimes visited by christians.

About nine in the evening, great bowls of couscous were served for supper. The sherifs, being persons of high distinction, ate first, and sent us the remainder.

On the 12th of August, at five A. M. we quitted Soforo, and again observed in its outskirts a long line of pleasing gardens : the road, shaded by trellises of fig-trees, is paved with flints to the distance of nearly three or four miles from the town. As we gaily pursued our route northwards, we fell in with many Jews proceeding to the market of Fez, which place we also reached about noon. The road had been good, less stony than that we had previously traversed; but the ground was little cultivated.

Having neither acquaintance nor letters of recommendation, I took up my lodging with my muleteer at the fandac. After a short repose upon a mat, I was desirous of visiting the market. To reach it I passed through several dirty narrow streets of low buildings. The market is held in a street under a roof of trellis-work and straw; the dealers occupy little shops, five or six feet square, raised about three feet above the surface of the ground. Men keep these shops and sit there the whole day in the fashion of tailors on their board. No one took notice of me, and I bought for three fe- 
louses* a small loaf and a few grapes upon which I dined; then returning to the fandac I passed the night there with the asses and mules.

On the 13th, 1 went with a negro of Mequinaz to visit the upper part of the town; this good-natured man took pleasure in shewing me its curiosities. We inspected several mosques: one in particular attracted my attention as the finest ; it is called by the Moors Mouladrib.

Wishing to proceed as soon as possible, I risked changing two English crowns, in order to hire a mule to carry me to Rabat, where I hoped to find a French Consul. I applied first to a Moorish merchant, who bore the character of being very devout; he weighed my pieces and offered much less than their value; I was refusing to part with them on such terms when a Jew blacksmith passed us, and the Moor proposed to him to purchase them. Notwithstanding the bad character of his race, he proved less usurious than the $\mathrm{Mu}$ sulman. After weighing the crowns in scales which he always carried about him, he offered me a price much above that of the zealous follower of Mahomet; I therefore treated with him : but having at the moment no money at hand, to avoid detaining me he requested the Moor to pay me the price agreed upon. The latter hastened to comply, but gave me coin which would not pass without a diminution of one fourth of its value. Such is the charity of these avaricious hypocrites, who abuse with impunity the ignorance and simplicity of an unfortunate stranger.

The Moors all questioned me incessantly upon my travels ; they pitied'my sufferings, but not one of them invited me to eat; they gave me no other consolation than the assurance that God would not abandon me, but that it would please him to restore me to my country and my friends.

On the 14th, fearing that a longer residence in $\mathrm{Fez}$

* Felous is a generic word signifying coined money. At Fez this name is also given to a copper coin resembling the gu of Egypt. 
would be injurious to my health, I made preparations for removing to Mequinaz : this, it was observed, was not the road to Algiers, but I was unwilling to increase my distance from Rabat and Tangier, and reported my intention in going to Mequinaz to be to throw myself at the feet of the Emperor, and make known to him my miserable situation ; not doubting that his compassion would furnish me with the means of proceeding to Algiers, whence I should more easily obtain a passage to Alexandria. The importance of this application to the sultan being obvious, no farther observations were made on my project. I was happy in finding so satisfactory a pretence for approaching the sea coast, but internally resolved to avoid the Emperor as solicitously as I affected to seek him.

Fez is the finest town I have seen in Africa; I shall endeavour to describe it as minutely as the shortness of my stay there will permit. 


\section{CHAPTER XXVII.}

Description of el-Fez.-Markets, monuments, gardens, police.-Mequinaz.-Inhospitality.-Arm of the sea called Sbo.-Arbata or Rabat, the ancient Sallee.-Visit to the Consular Agent.-The traveller avoids the camp of the Emperor of Morocco.-Writes to the Vice Consul M. Delaporte.-Larache.-Arrives at Tangier 7 th of September, almost dying, emaciated by want, fatigue, and fever.-Generous reception of M. Delaporte.-Anxiety of the traveller.-Is introduced by night and concealed by the Consul.-M. Delaporte obtains from the naval commander of the Cadiz station a vessel to convey him to France.

EL-Fez, so called by its inhabitants, but designated on the maps by the name of $\mathrm{Fez}$, is a large city belonging to the empire of Morocco, of which it was formerly the capital. It is situated in a species of natural tunnel formed by lofty well-wooded mountains, whence spring several considerable rivulets, which, after fertilizing the valley, supply the city with excellent water. Every mosque contains jets d'eau, and in several streets there are fountains for the refreshment of the thirsty passenger: here are also several water-mills for grinding corn. The city extends from east to west and must be about four miles in circumference, as far as I could judge from a survey of it from the top of a hill. It is surrounded by a double brick wall, about twelve or thirteen feet high, well constructed and ornamented at intervals with raised copings. I was astonished by the regular architecture of a spacious gateway, in the form of a triumphal arch, through which the city is entered. Under this arch were established a number of venders of provisions.

Within the compass of the outer wall are some gardens, and small low houses, called the suburbs; here I observed 
some manufactories of Delft ware and tiles. The houses have terraced roofs like those of Timbuctoo, and are built of bricks perfectly well formed and baked in a kiln. Their masonry is not very correct: small, square and strongly grated windows overlook the streets; and the outsides, which are lime-washed, are much out of repair; they have generally a story above the ground-floor, which receives air and light only from an inner court.

The streets are paved, but narrow, winding, dark, and dirty to the last degree; I saw in some places, dogs and cats which had been long dead and emitted a pestilential stench.

These streets are nothing more than galleries covered by trellises or masonry, which deprive them of a free circulation of air, concentrate all the disagreeable effluvia of the city, and render it very unwholesome.

The principal manufactures of $\mathrm{Fez}$ are blankets and gunpowder; ploughs and wooden spades are also made there, and the city contains locksmiths, cutlers, shoemakers, tailors, masons, blacksmiths, who likewise act as farriers, and gunsmiths, but the fabrication of their guns falls far short of the perfection of ours.

Shops may be found in most quarters of the town furnished with all sorts of provisions, dried or otherwise; as bread, meat, butter, pastry, fruit, and vegetables. As there are no inns, travellers without acquaintance in the city have no other resource than to buy what they want at these shops, and to carry it to the mosque or to the fandac to eat.

A market is held every day; it is attended by a great concourse of strangers, who cone from great distances to sell their commodities : great quantities of dates and tanned leather are brought to this market from Tafilet; the inhabitants of the mountains supply it with honey and wax, of which last candles are made, not only for home consumption, but for large consignments to the principal maritime towns. 
For the security of the shops, dogs are every night turned loose into the streets of the market; these animals, trained for the purpose, perform their duty so zealously, that, but for the interference of men who sleep near, they would inevitably devour such passengers as chance or business attract to the spot confided to their charge.

No monument of departed splendour exists at Fez to awaken curiosity or recal the former magnificence of the conquerors of Spain : but it boasts of many mosques, each surmounted by a square tower of about a hundred feet in height, upon which a white flag is hoisted as the signal for prayer. I visited several of them, accompanied by the goodnatured negro of Mequinaz; and found them large edifices of an oblong square form, containing several galleries raised upon well-built arcades. The only one which appeared to merit particular attention is called by the Moors Mouladrib, probably from the name of its founder. It is the chief ornament of the city. The interior is preserved with the utmost care; it is paved with small pieces of well varnished Dutch tiles, of various colours and shapes, tastefully arranged in mosaic ; and the whole compass of the walls, to the height of two feet and a half, is inlaid in the same manner. The arches which support the roof are of far superior workmanship to those of the other mosques; two of them are raised on finely sculptured marble columns, the other pillars are of brick, covered with plaster. The vaulted ceiling is composed of boards, painted yellow and red, and adorned by a broad band of gold colour forming the cornice. Within a sort of sanctuary, in the middle of the mosque, stands a small altar, covered with a cloth embroidered with flowers in gold; and around it are placed several glass lamps and flambeaux, and near it is a handsome lustre hanging from a gilt cupola; a multitude of suspended lamps are also dispersed throughout the temple, to enlighten the faithful. The thirsty traveller is refreshed by a very beautiful fountain 
which plays in an inner court and invites numbers to sleep within its cooling influence.

Neither inns nor hotels are to be found in Fez; their place is supplied only by fandacs similar to those which I have already described. Here travellers who possess beasts of burden are obliged to sleep on the ground beside them, and themselves to provide them with forage. They usually take their meals at the mosque, pass the greater part of the day there, and would sleep there if permitted. The proprietors of the fandacs exact six felouses per head for the cattle, a sum equivalent to two French sous.

Two hills, which command the city are defended each by an insignificant fortress, having embrasures but no cannon: one is situated nearly S. E., and the other, in which some prisoners were confined, is to the N. W.

The immediate environs, for two or three miles round, are highly cultivated, and produce abundance of vines, and olive, fig, apple and pear trees; near the wall are mulberrytrees of considerable height. I have seen flower-gardeners selling in the markets a great variety of flowers, similar to those which adorn our parterres in France. At some distance from the town are a great number of little mausoleums, in which the remains of the most distinguished sherifs are deposited.

Fez is computed to contain about twenty thousand inhabitants, all either artificers or traders, who carry on an extensive commerce in European manufactures, which they export to Tafilet and Timbuctoo as well as to the adjacent mountainous countries.

The 14th of August, at seven in the morning, I quitted the fandac and walked through the city with my leathern bag thrown over my shoulder. A long street conducted me to the western gate, where I hired a mule to carry me to Mequinaz; and, our provision for the journey being prepared, we departed, directing our course W. N. W., over a smooth 
soil composed of very good mould but uncultivated. I remarked several tents of wandering Arabs pitched beside a little river formed by the junction of the rivulets which water the environs of Fez. Our road, which was very uneven, lay between two ridges of barren hills, and crossed several well constructed bridges.

About two o'clock we rested under a bridge which sheltered us from the sun. We had in our company two women who, being under no restraint, shewed but little solicitude to conceal their fair complexions and pretty faces beneath their veils; one of them rode on my mule behind me; and I presume that my attentions were agreeable to her, as she offered me a slice of melon and a bit of bread which I accepted with pleasure. Our pretty fellow-travellers, however, learning that the Emperor had set out for Rabat, returned to $\mathrm{Fez}$, and I continued my route with my guide alone; our mules keeping up so good a pace that I estimated our progress at four miles an hour.

At five in the morning we arrived at Mequinaz, the streets of which city were as dirty and narrow as those of Fez; and, entering a fandac, I begged to be allowed to sleep in a stable, a favour which the master refused in the rudest manner. Turning from a place which offered so little hospitality to an unfortunate stranger, I sought refuge in the mosque, the asylum of the indigent: there $I$ hoped to repose in peace till the morning; but alas! I was disappointed. About ten at night an old bamâb (porter) came to me, and kicking me, roughly desired me in a hoarse voice to rise and begone, for he was about to shut up. In vain I represented myself as a stranger not knowing whither to go, and implored him to allow me to pass the night in this retreat: without the least regard to my situation he compelled me to leave the mosque. Such conduct ought not to have surprised me, for in this part of Africa, as in some other more civilized countries, men are distinguished only by their ap-

VOL. II. 
parel, and it must be confessed that mine did not plead in my favour; but I considered that it would be highly imprudent to study my dress : my rags excited no attention, and this livery of poverty served as a veil with which prudence required that $I$ should still envelop myself.

I possessed some pieces of silver and four buckles made of gold from the mines of Bouré; but, as it would have been dangerous to shew them, I took my bag upon my shoulder, and left the mosque, uncertain where to find repose for my sick and wearied frame. For a short time I wandered about the streets meditating on my forlorn condition, and, oppressed by the recollection of the humiliations, fatigues, and privations which I had already endured, and by the chilling sense of those which I still experienced, I could not altogether suppress my tears. Let me hope this weakness was excusable in my disastrous situation: it was within sight of the desired haven that I was most in danger of shipwreck. With a heart sinking under these reflections, I sought shelter in the shop of a dealer in vegetables, who, taking me at first for a Berber, would not suffer my intrusion; when, however, I told him that I was an Arab, he left me in tranquillity to pass the night on the ground. Laying my head on the leather bag which contained my notes, I enjoyed a short forgetfulness of misery, but was soon awakened by the cold, and sleep solaced me no more during the night.

August the 15th, at six in the morning, hastily quitting this inhospitable place, I resumed my journey towards Rabit on foot, carrying my bag, and but scantily provided with food.

Beyond the town I passed some gardens, and several plots of well cultivated hemp. I soon discovered that it would be impossible for me to reach Rabat on foot, for my limbs had scarcely strength to support me, and the pain which $I$ felt in the spleen was aggravated by fatigue. Rest- 
ing therefore for a moment against a wall I considered how I should proceed, and finally determined upon returning to the town. Taking my purse out of my bag, and observing with sorrow that its contents were much diminished, I was nevertheless under the necessity of abstracting a few shillings from what remained, proposing to change them on my return to Mequinaz, to procure me a conveyance. Inadvertently I laid my knife and pocket-compass on the ground beside me and forgot them. Much grieved by their loss, I returned from the city to seek them, but unhappily in vain. As I again approached the city I saw several Spaniards, who had been shipwrecked on the coast, followed by a crowd of Moors, and escorted by soldiers, armed with sticks for the purpose of preventing the pressure of the crowd; they were being conducted to the Emperor, and I remarked with pleasure that they were not ill-treated. A Jew, who spoke the Spanish language acted as their interpreter. I followed them a short distance, but, finding it impossible to penetrate to them, returned towards the market, and seated myself at the door of a Berber, who, perceiving that I was suffering pain, asked me who I was and what ailed me: I told him my story, which, like all his countrymen, he believed. Having imparted to him my intention of hiring a conveyance to Rabat, in the hope of seeing the Emperor and applying to him for assistance to enable me to return to my own country, this good Berber induced me to place my bag in his shop and promised himself to negociate with the muleteer for the fulfilment of my wishes.

In the course of the day, I visited the fandacs, and there met with a man from Tafilet, who proposed to me to hire an ass for my conveyance to Rabat. I took him to the Berber, and, having agreed upon the price, which was fixed at a piastre and three quarters, I paid him the earnest; we were to set out the following day. In the evening I bought some fruit and bread for my guide and myself. 
On the 16 th of August, at six in the morning, I mounted my ass, not without the assistance of my guide, which on account of my weakness I was unable to dispense with : we travelled due north for about an hour, then turned N. W. till nine in the morning. The route is interrupted by hills, and turns a little to the south. About two o'clock we halted under the shade of a zizyphus lotus, to repose during the extreme heat : at three we resumed our route to the north, till half-past four, and then proceeded N. W. On the road we met a traveller in the utmost distress on account of the death of his horse, for, besides the inconvenience of prosecuting his journey on foot, the poor man was compelled also to carry his saddle to some inhabited place; my guide took pity upon him and placed his saddle behind me, which suited me well, for I was so weak that I could scarcely sit up, and this saddle made a convenient support for my back.

At six in the evening, we reached a considerable brook, which runs S. S. W., and afterwards west, and stopped to slake our thirst at it. I had been suffering from fever nearly the whole day, and the heat had been overpowering; I now lay down to take a short repose. During this halt, the Moor, who was not the owner of the horse he had lost, obtained from a sherif a certificate of its death: the sherif, having interrogated me in common with the other witnesses of the event, gave on our evidence the writing which testified that the horse had died without any fault on the part of its rider.

At sun-set, after having eaten some figs given us by the Berbers, we proceeded northwards till eight o'clock, when we reached a camp, provided with a tent that served as a mosque, and was destined also for the reception of travellers; we took up our quarters in it, and the inhabitants of the camp brought us supper. This spot is covered with prickly shrubs.

At two o'clock in the morning of the 17 th, we quitted 
this hospitable camp; for half an hour we were followed by a troop of nearly thirty dogs, which barked incessantly, and even bit our beasts. At five o'clock, turning to the N. W. we proceeded over level ground covered with a fine vegetation. Towards eight in the morning, we halted for an hour beside a well, where we breakfasted upon fresh bread, and some water-melons which we had found in the fields. After this rural repast we drank some pretty good water, which we were able to take up by hand, the wells being shallow. We continued our route to the N. W., and at eleven o'clock, the heat being violent, again halted under a beautiful clump of fig-trees, where several travellers were sleeping; we rested till noon, my guide, who was sufficiently complaisant, having some consideration for my illness. After this short repose we proceeded still towards the N. W. till three P. M. when our direction turned E. S. E.; we now journeyed over loose sand. At half-past two we stopped before a camp of soldiers, who were on their march to rejoin the emperor; they had pitched their tents near an arm of the sea, which my guide told me was called Sbo.* To my great surprise tolerable order was preserved in this camp: the centinels were placed at equal distances from each other, but they slept the whole night; the chiefs were lodged in handsome tents, having a centinel at the door, and soldiers around them. The women of the neighbouring districts supplied them with bread.

On the 18th, at three in the morning, we set forward, crossing the camp, where the soldiers were still all asleep; but one, waking up with a start, exclaimed: "Who goes there ?" This did not however interrupt our progress. Farther on we encountered the advanced guard, also asleep, but our noise disturbed them, and waking up they inquired

* This is the river which on the maps is called Sebou, and into which the sea ascends. 
who we were and whither we were going: upon receiving our answer they permitted us to pass through the midst of them, for there was no other road, and it was necessary to cross a bridge. We proceeded by a fine road to the S. W.; the soil composed of grey sand is naturally fertile. At eight in the morning we halted to take a slight repast of bread and some nuts purchased at Mequinaz, and ate it in peace beside a well. We continued our route to the S. W. over a soil similar to that which I noticed over-night, and arrived at an arm of the sea on the opposite shore of which Rabat is situated; here I saw several Portuguese vessels. The vine flourishes in the environs of this town, and the fields are well cultivated.

Upon entering Rabat, I proceeded with my guide to the fandac, where $I$ rested awhile and then set out to walk through the town in hopes of finding the French consul, for I concluded that there would be one here. I held some shillings in my hand, by means of which I proposed without committing myself to find the consular house. I begged several Moors to change them for me, knowing that they would not (for they have little complaisance) but I foresaw that they would refer me to a christian, to whom I hoped by this innocent stratagem to be enabled to speak without exciting suspicion. In fact, the first Moor whom I requested to change my shillings for the coin of the country directed me to the christians; I took advantage of this circumstance to inquire for the French consul, saying, that the money was French, and he, having no suspicion of me, immediately pointed out the consul's residence. I knocked at the door, and was thrilled with joy at the thought of being about to see a Frenchman.

A Jew, who spoke tolerable English, opened the door; he told me that the consul was at this moment with the sultan, but that he would soon return. I retired for a short time, and on my second application was by the same Jew 
presented to the French consul at Rabat. Gracious God! how was I disconcerted, when I found that he was himself a Jew ! I was so thunderstruck that I remained for a moment speechless; meanwhile he addressed me in pretty good French, inquiring what I wanted with him : recovering a little from my stupefying surprise, I shewed him my shillings and begged him to change them; an English merchant who chanced to be with him, and to whom I confided my secret, assured me that I might safely communicate to the Jew the true cause of my application to him. I then told the consular agent that I wished to converse with him for a moment in private, upon which he shewed me into his warehouse and seated me upon the floor. There I informed him that I was a Frenchman, that I came from the Soudan, and that, desiring to return to my own country, I claimed the protection due to a subject of the King of France. The Jew asked if I had any papers, and if I was travelling by order of the government: having satisfied him on all these points, he opened a French book of geography, and pointed out upon a map the Senegal and other districts, no doubt to display his learning: he then shewed a letter from M. Sourdeau, consul-general of the King of France, announcing his nomination to the dignity of consular agent at Rabat; but he gave me to understand that he received no pay, and that in consequence I was not to expect much assistance from him; then dismissing me, he recommended me strongly not to make myself known if I valued my head; for, added he, the Moors are no triflers on the subject of religion.

I then returned to the fandac, leaving with the consular agent ten shillings, which he refused to change; he gave me however on account, three dragmes (twenty four sous) for the supply of my most urgent wants during the following days. I made my guide purchase a piece of roasted mutton and two small loaves, which I divided with him ; resolving 
however that this should be my last repast in his company: not that he had been deficient in complaisance to me, but, convinced that I must be extremely desirous of an interview with the sultan his master, he was perpetually endeavouring to pursuade me to solicit one. I had exhausted all my pretences for delaying this step; and had sufficient reason to beware of presenting myself before the African monarch, who, more suspicious than his subjects, would in all probability have proved more clear-sighted.

I quitted the fandac therefore, and passed the day at the corner of a street; where I hoped to spend the night with equal tranquillity, and lying down enveloped myself in my large wrapper. I was invoking sleep, the friend of the unfortunate, when a dozen dogs began to bark furiously at me, and I should certainly have fallen a prey to these ani . mals, had I not been promptly assisted by one of those men, who are posted in the streets at night expressly to rescue passengers from their attacks. This man inquired who I was; "I am an Arab, a stranger here," replied I, "on my return to Alexandria my native country." Upon this he placed me in a small recess near which he slept himself; arming me with a strong bamboo cane to drive away the dogs, if they should trouble me again; a very judicious precaution, for these creatures, apparently conscious that I was a stranger, never ceased throughout the night annoying me with their menacing cries. I would gladly have slept at a fandac, but for the expense of three paras per night, and the risk of insults from the muleteers. Consulting my poverty, and uncertain when I should be able to obtain assistance from the French Consul, I determined to be as saving as possible and to sleep under the canopy of heaven. Henceforth $\mathbf{I}$ sought repose in a cemetery, situated to the west of the town on the sea-shore, where, peacefully extended at the foot of a mausoleum, I was neither tormented by men nor dogs. During the day I remained at the corners of the streets, 
sometimes repairing to the mosques to take my melancholy meals, consisting of a little bread and a bunch of grapes, to which I occasionally ventured to add from my scanty resources a small piece of fried fish. As the wells of Rabat are brackish, I was obliged to beg water from the Moors who seldom refused me. Such was the kind of life which I led, during the whole of my residence at Rabat, while waiting for an opportunity to proceed to Tangier to the French Consul. I now and then saw Ismael, the Jew agent of the consulate, who gave me some small coins of the country, on the security of the ten shillings with which $I$ had entrusted him. One day, finding him at home at breakfast, I was invited to sit upon the floor and partake of his tea. I entreated him to procure for me some means of travelling to Tangier; promising to reimburse him as soon as I should reach the consul; but the Jew, fearing no doubt that this would be disapproved by his superior, drily refused. Seeing that nothing was to be gained from this man, not even permission to embark on board a Portuguese brig, bound for Gibraltar, I was about to write to M. Sourdeau, Consul-general at Morocco, when Ismael received a letter from Tangier informing him of this gentleman's death; I therefore addressed myself to the Vice-Consul M. Delaporte, on whom the direction of the consulate had devolved; but an opportunity of going to Tangier occurring during the interval, while I awaited his answer, I hired an ass to carry me thither, for my legs would no longer support me.

On the 2nd of September, I quitted Rabat with the owner of my ass, the most worthless man I had met with in this country. The poor beast destined to carry me, was already oppressed by a heavy burthen, and sunk at every step up to his knees in the loose sand of the sea-shore; I had therefore no alternative but to dismount, and though I had paid a good price for my conveyance, and was scarcely able to drag myself along, was obliged to perform half the journey on foot, 
while my unworthy guide rode forward with the utmost indifference. On reaching the place appointed for the halt, I threw myself down under a tree, and wrapped up in my old blanket, suffered there a violent attack of fever, produced by fatigue and exhaustion. Towards seven in the evening, my guide brought me a handful of couscous, which had been given him by some Arabs near whom we had encamped.

At Larache I saw two vessels cruising, and little thought that one of them would shortly bear me from this frightful country. I ascended with difficulty the hills in the vicinity of Tangier, and at length, ill, and worn out with fatigue, I arrived in that town on the 7 th of September, at nightfall.

As I entered on foot the centinel took no notice of me, and I thus fortunately escaped an explanation with the governor of the town, which might have thrown some obstacles in the way of my departure, or even have involved me in destruction. I deposited my bag at the fandac, and the same evening explored the town in search of the French Consulate. I saw many flag-staves, but could not for the darkness distinguish that of my own nation. The moment was most critical. I dared not to address myself to a Musulman, who would infallibly have asked what concern $I$ had with the christians: and if my intentions had been discovered I should have lost all hope of restoration to my country. I lay at the fandac, and passed the night in extreme agitation. In the morning I again repaired to the street where I had seen the flags, and perceived an open door, near which stood a christian; looking carefully round, to ascertain that I was not observed, I accosted him in English, inquiring for the residence of the British Consul. "This is it," replied he ; but, fearful of attracting notice, by conversing too long outside the door, I would have entered the house, to ask a direction to the French Consulate; but this man, who I supposed was a domestic, repulsed me with horror, on account of my dirty and disfigured appearance. I inquired for the residence of the French 
Consul, and he bluntly answered, "He is dead," but at the same time called a Jew, who directed me to the door of the Vice-Consul, and with an air of curiosity, asked who I was, and what I wanted with a Christian; I retreated without answering, trembling with the dread of detection. When all whose observation I had excited had passed on, I returned to the Vice-Consul's door, which, being opened, I entered the house : a Jewess called M. Delaporte who received me with the greatest kindness, and conducted me up stairs to an apartment where I was entirely concealed from view. I comprehended the full extent of the danger which surrounded me, from the fear which M. Delaporte expressed of the difficulties which must embarrass my departure from this country; but, speedily laying aside any uneasiness relative to my present situation, he gave free vent to the joy with which my almost miraculous escape from the dangers of so arduous a journey inspired him, and in his transports even embraced me, pressing me closely to his arms, notwithstanding the dirty rags in which I was clad : I cannot indeed speak too warmly of the benevolent reception which I experienced from this generous man. After enjoying a breakfast from his hospitality $I$ found myself, with great regret, obliged to depart, though we had not yet determined on any means for rescuing me from my present embarrassing situation. No sooner had I set foot in the street than I most inconveniently encountered my muleteer, who, seeing me come out of a house, inquired where I had been; at first I felt a little confused, but quickly recovering I told him that a charitable priest had given me a breakfast in that house. I returned to the fandac, and did not leave it again that day, apprehensive of exciting attention, as those by whom I had been seen had inquired whether I was a renegado.

I passed the night in contriving means to obtain another interview with the Vice-Consul. In the morning the master of the fandac came to demand three felusses for my night's 
lodging in his stable, and then, pushing me by the shoulders, sent me to return thanks to God and the Prophet.

At nightfall I again presented myself at M. Delaporte's house : as I was entering, the female servant, not recognizing me, ran back uttering a loud cry; this brought from the street the Vice-Consul's guard who, precipitately entering the house, put his hand upon my shoulder, and demanded who I was, and what I wanted. I was completely disconcerted, M. Delaporte, being brought down by the noise, knew me, but affected great anger, and spoke very harshly to prevent suspicion. "Turn out this dog of a beggar," said he, "what can he want here? begone !" The soldier still asking what I wanted, I examined the house as though in doubt; and saying, "What! does not Sidi-Mohammed reside here ? I fear I have made a mistake," I retired; the soldier following me a short distance, but by favour of the night I easily escaped him. On my return to the fandac I threw myself upon the ground, to recorer from the emotion which this untoward accident had occasioned. After an hour's repose, I again repaired to the street where M. Delaporte resided, hoping that he would send some one to me with a message of encouragement; but I saw no one. I passed another agitated night, sleeping little; and at day-break took my station in front of the Vice-Consul's house to seek a decisive interview with him, the suspense in which I continued having become insupportable. I seated myself at the door of a poor shoemaker, to watch the moment when I might enter the house without observation. The Jewish maid servant, who had been so unfortunately alarmed the preceding evening, recognized me: and, having given notice to $\mathbf{M}$. Delaporte, made me a sign to come in. The Vice-Consul obligingly expressed his regret for the unpleasant scene of the preceding evening; he did not dissemble his apprehensions for me, in case I continued long in my present situation, but could devise no means for my escape ; I was still more perplexed, as 
without his assistance I should find it impossible to quit the country. Seeing me resulved to extricate myself as speedily as possible from this state of distress and anxiety, M. Delaporte fixed an hour of the night for my return to the consulate, to quit it no more till I should be enabled to embark for Europe. I spent the remainder of the day at the fandac, and that my sudden disappearance might occasion no surprise amongst its inmates, I apprised them that I intended to proceed to Taone on my route to Algiers. When it was quite dark, I rolled my bag in my wrapper to screen it from observation, and repaired to the appointed spot, where I immediately saw M. Delaporte and a Jew, who came to conduct me to my destined asylum. I was admitted to the Consular residence by a back door, and led to a good chamber, where M. Delaporte presently sent me a European dress, for which I gladly exchanged the dirty rags I had so long worn: he then visited me in my new apartment, and expressed the greatest satisfaction at seeing me in a place of safety.

After returning thanks to Almighty God, I lay down upon a good bed, rejoicing in my escape from the society of men debased by ignorance and fanaticism: Though all my wants vere relieved, I found it impossible to close my eyes the whole night, so much was I agitated by the remembrance of the perils I had passed through. During my whole residence at the Consulate, M. Delaporte came many times each day to see and converse with me ; he treated me as his own son, and indeed lavished on me all the cares of the tenderest father.

It would be difficult to describe my sensations on casting off for ever my Arab costume; I retraced in my memory all the privations and fatigues I had endured, and the length of route $I$ had traversed in a wild country, amidst a thousand dangers. I blessed God for my arrival in port; but I believed myself in a dream, and asked if it was indeed true that I might soon be restored to my country, or whether this enchanting hope was but a delusion. 
M. Delaporte neglected nothing that could contribute to the re-establishment of my impaired health, and the wholesome nourishment he gave me effected a decided improvement; but I was still frequently attacked by paroxysms of fever which kept me in a state of extreme weakness. During my abode in the consulate $I$ was occupied in arranging my notes.

Besides the frequent and agreeable visits of the Vice-Consul, I received also those of a Jew domestic to whom the secret of my seclusion was confided: this man, though a Frenchman, was thoroughly imbued with the principles of his race and had no ideas but for the advancement of his interests. He undoubtedly believed that my views were the same, and advised me to carry the fruits of my travels to England; representing to me that this nation had offered a reward of twenty-five thousand pounds sterling for the accomplishment of the journey to Timbuctoo. Instead of listening to so contemptible a proposition, I replied, that I was a Frenchman, and added: "The recompence to be derived from the French government would undoubtedly be less considerable; but I should not hesitate a single moment to offer to my native country and my king the homage of my modest labours."

The excellent M. Delaporte wrote very pressingly to the commander of the French station off Cadiz, describing in lively colours the dangers to which I was exposed by a longer residence in this place. The commander, determined by his solicitations, sent one of the king's sloops to Tangier to convey me to 'Toulon.

On the $27_{\text {th }}$ of September 1828, a little before sunset, a sailor's dress was sent me as a more convenient disguise. A Moor inquired who I was, saying that he had not seen me disembark with the others; the Jew, who attended me, answered that I was a Frenchman from 'Tetuan, returning to France, and the Moor made no farther remark. I embarked 
on board the sloop La Légere, suffering much from fever, and the Commander Jolivet supplied me with every thing necessary in my situation.

On the 28th, at six in the morning, we set sail with a fair wind, and to my great satisfaction soon lost sight of 'Tangier. M. Jolivet's cares had a beneficial effect upon my health; the fever left me, and the fine sea-breezes soon completed my recovery. We arrived at Toulon after a very favourable voyage of ten days.

Those who have been long absent from their native land, and have good cause to fear that they may never return, can alone form an idea of my sensations on my restoration to $\mathrm{my}$ beloved country. While in quarantine I wrote to M. Jomard, President of the central commission of the Geographical Society, to announce my travels to him. I soon after received, as the first proof of the benevolent interest of this learned association, the sum of five hundred francs, to defray the expenses of my journey to Paris : nor was it long before I enjoyed the glorious reward of its merited approbation. The society applauded my zeal, and awarded to me the recompense promised to the first traveller who should penetrate to the mysterious town of Timbuctoo, and bring from thence his authentic observations. The government graciously received the Society's report upon my travels, and soon bestowed upon me distinguished marks of its munificence and honourable protection.

But this flattering success raised adversaries against me : some alleged that I had never reached Timbuctoo; others, that I had been shipwrecked on the coast of Barbary, and, having obtained possession of some vague intelligence respecting the interior of the country, had imposed it upon the public for the results of my personal observations. I have been even accused of changing my religion at every station. To this malevolent imputation, I answer: that I externally adopted the forms of the Mahometan worship as the only 
means of penetrating into the countries through which $I$ have travelled-an achievement which, without this acquiescence, would have been impracticable, except by encountering at every step the hazard of death, and inevitably suffering it at last. I must confess that these unjust attacks have affected me more sensibly than all the hardships, fatigues, and privations, which $I$ have encountered in the interior of Africa. 


\section{GEOG R A P H IC A L}

\section{R E M A R S A D I N Q I R I E S}

CONCERNING

\section{THE TRAVELS OF M. CAILLIÉ,}

\section{IN CENTRAL AFRICA,}

BY M. JOMARD, MEMBER OF THE INSTITUTE;

\section{COMPRISING}

AN ANALYSIS OF THE MAP OF THE ROUTE AND THE

General MaP of The travels, DRAWN UP By THE SAME;

Followed By vocabularies COLLECTED By M. CaIllié, his ITINERARY DAY BY DAY, EXPlanations OF THE Plates, AND NOTES

on SEveral points OF NATURAL HISTORY AND GEOGRAPHY;

CONCLUDING WITH DOCUMENTS AND OTHER PAPERS. 

G EOG R A P H I C A L

\title{
REMARKS A N I NQUIRIES CONCERNING
}

\author{
THE TRAVELS OF M. CAILLIÉ,
}

IN CENTRAL AFRICA.

\section{CHAPTER I.}

$\S \mathbf{I}$.

GENERAL RETROSPECT OF THE PUBLISHED INFORMATION ON THIS SUBJECT PRIOR TO M. CAILLIÉ'S TRAVELS.

A powerful interest is attached to travels in central Africa: any attempt, therefore, to explore this part of the world can scarcely fail to excite curiosity, provided, at least, that it makes some addition to the knowledge previously acquired and supplies one of the deficiencies of geographical science; that is to say, if it furnishes authentic documents concerning the respective situations of places, their topographical positions, and relative distances; concerning the natural productions and physical geography of the country; the population, commerce, 
interior navigation, industry, and agriculture; the manners, customs, religious worship, superstitions, and language of the people, or the physical conformation of the inhabitants ; in short, provided it is calculated to interest the geographer or the naturalist, the historian or the person engaged in commerce and manufactures. The merit and usefulness, indeed, of a narrative of travels consists in these positive results. The attentive reader will discover in the simple journal before him more than one such result, especially in matters of geography, the nomenclature and position of places, the course and importance of rivers, the situation of mountains, and generally speaking, every thing relating to the accidents of the soil. The various tribes, also, visited by M. Caillié, and in the midst of which he lived, presented so many subjects of observation that it was impossible he should not attempt, at least, to sketch their portraits. To the well-informed public it belongs to appreciate whatever is new and interesting in this simple and inartificial picture of nations and tribes scarcely known in Europe, even by name. I must not, however, rest here, but will turn my undivided attention in the first place to examining and discussing all the points of geography connected with M. Caillié's route. Before I proceed to this discussion, for which I shall need all the indulgence of the reader, I shall take leave to cast a glance upon the explorers who preceded him, and the information we possessed anterior to his travels. Notwithstanding the advantage which $M$. Caillié has over all his predecessors, in having brought to Europe a description of the city of Timbuctoo, written on the spot, several motives 
induce me to recapitulate here the prior attempts which have been made by others, each of which enterprises has formed an additional step in the career which he alone has been enabled to pursue to its accomplishment. After this examination of the discoveries and relations of preceding travellers, I shall analyse the map of the route annexed to this work. It has been constructed from the materials furnished in minute detail by the journal of the French traveller, and which also form the basis of the general map of the journey. I shall then treat of the nomenclature of the countries through which he has travelled, of the course of the great river, which, like Mungo Park, he has navigated, and of the acquisitions for which science is indebted to him, without neglecting the questions connected with the theatre of his discoveries.

Whoever studies the history of the discoveries in the interior of Africa is obliged to go back to the learned cosmographer el-Edricy, who may be styled the Prince of Arabian geography. Till now, an extract only of his description has been known, but a learned oriental scholar* has just discovered a much more complete manuscript than that which was translated into Latin at the com-

* M. Amédée Jaubert has already presented to the Geographical Society a translation of the first climate of the geography of el-Edricy, from the manuscript which he has discovered : the entire work will be printed in the collection of this society's memoirs. The Rev. M. Renouard is also preparing in London, a translation of another inelited manuscript of the same geographer. 
mencement of the 16th century, and which the learned Hartmann has commented upon. While waiting for the benefit of the translation preparing by $\mathbf{M}$. Amédée Jaubert, I shall quote from the Latin version* the description of the countries which $\mathrm{M}$. Caillié has visited, but which form only a very small portion of the theatre of his peregrinations. According to el-Edricy, Segelmassa or Sidjilmessa, a town in the country of Tafilet, is forty days' journey from the Soudan, that is to say, from the inhabited districts and fertile soil of this immense region; it is also computed to be forty days' journey to Tocrur or Takrour, to Salla or Sala, and to Ouhl. Sala is on the northern and Takrour on the southern bank of a river called Nile. Sala is two days' journey from Takrour whether by land or water.

The place named Oulil, described as an island properly so called, is the great mart for salt in those parts, and is situated sixteen days' journey from Sala. Eastward of Takrour are several large towns; Ghana, at a distance of twenty four days, and Berissa of twelve ; from the latter Aoudeghest $\uparrow$ is twelve days' journey towards the north and the district of Lamlem six to the

* See Geogr. Nubiens, by Gabriel Sionit., p. 7, 9, Paris, 1619, in-4to, and Hartmann, Edrisii Africa, p. 28 to 55 and pass. Gotting. 1795, 8vo.

+ Agadez, according to M. Walckenaer. See his learned Recherches géographiques sur l'Intérieur de l'Afrique Septentr. p. 11, in which work almost all the materials which should be consulted by those who are studying the history of African discoveries are quoted and collected. 
south; this contains Wangara, Maleb, and Dau, four days' journey from each other; to the west is Meczara, to the east, Vancara, to the north Ghana, and a desert to the south.

Many of these statements agree sufficiently with $\mathbf{M}$. Caillié's marches across the desert; I can here only slightly mention this conformity, because it would be necessary otherwise to enter into details on the extent of a day's journey and on the different kinds of days' journeys ; an important question which shall be discussed elsewhere. Takrour corresponds perhaps with the locality which has since become the seat of Timbuctoo* : the importance of this ancient town is proved by the name of Takrour, then given to the whole of the Soudan, and applied to it by the natives even to the present time. Sala is a point known to M. Caillié, but to the right of the route from Timbuctoo to Tafilet, and not to the west of Timbuctoo; and it must not be confounded with Ain-Salak, the oasis of Agably.

May not the Oulil of el-Edricy, so long sought, be an island in the sense understood by the word oasis, as surrounded on all sides by an ocean of sand? this place

* M. Walckenaer has already remarked that on the ancient map on wood in the King's library (of the middle of the 14th century) Timbuctoo is indicated by the name of Tenbuch. Its foundation dated about a century and a half earlier. Rech. sur l'Afr. Septentr. \&c., p. 14. 
would then correspond well with Tychyt, celebrated for its salt-mines; it is true however that the Arabian geographer seems to place Oulil upon the sea itself.*

With respect to Ghana, which is thought to answer to Kano, visited by the last English travellers, its position in el-Edricy appears too much towards the west; unless these travellers (as has been already suspected) have placed Kano and other points of the Soudan between Bornou and Saccatoo, too far to the east.

Above two centuries before el-Edricy, Ebn-Haukal, another not less esteemed Arabian writer, had fixed the relative positions of Sidjilmassa, Oulil, and Ghana; these equally agree with the itinerary of our traveller; every well informed reader will inquire whether the same agreement exists with the marches of the celebrated Ben-Batouta. His travels are known by the fragments which Messrs. Kosegarten and Burckhardt have translated from the extract given by el-Bilouni.†

It is known that, in 1352, Ben-Batouta quitted Sidjilmessa for Timbuctoo and central Africa: in twenty-

* Insula verò Ulil in mare sita est, etc. Geograph. Nubiens p. 7. But $b a h r$ signifies both river and sea.

+ This same extract more complete has just been published in an English translation by Mr. S. Lee, under the title of Travels of Ibn Batuta, etc. London, 1829.-During my abode at Cairo, I heard mention of a complete manuscript, the work of Ben-Batouta, deposited in the library of the Mosque el-Azhar. 
five days he reached the salt mines of Teghazza; $;$ ten days afterwards, Tas-hal; ten or twelve days farther on Aboulaten (Ejulat or Eiwelaten) it beyond that, Maly, at a distance of twenty-four days ; from Maly to Zaghary (or Sagher), ten days; and thence to Karsendjou (or Karseckou).

This place is washed by the great river, which is the Nile, and runs to Kabera and Zaghah (or Sagha); from Zaghah, the Nile flows towards Timbuctoo, Koukou (Kok), Mouly the last place of the country of Maly and Bowy (or Youy), one of the largest towns of the Soudan. Thence the Nile descends to the country of Nouba and passes Dongolah. From Karsendjou, Ben-Batouta proceeded to the river of Sansarah, ten miles from Maly, which he left after a residence of two months; some days afterwards he reached 'Timbuctoo on the Nile, Koukou, Berdammah, and Takadda (or Nekda). On his return to Sidjilmessa, he visited Touat, Kahor, Dekha, and Bouda; a journey of more than twenty-eight days or stages.

The obscurity of this recital must be confessed: it arises chiefly from the different ways of reading proper

* Perhaps تغاري Teghary as read by Burckhardt, or Tegherry, which would conduct him to the centre of the kingdom of Fez : M. Kosegarten read تخاز تُغازي in on of the manuscripts.

† Oualet, according to M. Walckenaer. 
names, in supplying the orthographical signs often wanting in manuscripts. Thus Burckhardt has read تغاري 'Tegherry, the same name which Kosegarten had read تغاز Taghazza, which would bring the traveller into the country of $\mathrm{Fez}$ very far from the Sahara. Tas-hala, a ابولاتر. is confounded with Eyoulaten إيولاتيك. or Oualet. Maly or Mala ماي is perhaps Sala سكالي for Tagada أ. \&c.

The places in the neighbourhood of Timbuctoo, according to Ben-Batouta, are Kabera and Zaghah. We still know Cabra, and the second of these names reminds us of the Meczara of el-Edricy, and the Mar-Zaghah or Marzarah of other accounts. Thus the distance of the places with which $\mathbf{M}$. Caillié became acquainted, and which in consequence $I$ have placed upon the general map of the Travels, Tychyt, Oualet, Sala, Cabra, and Timbuctoo, would nearly agree with the description of BenBatouta : I say nothing here respecting the direction of the rivers.

Few itinerary distances are to be found in the relations compiled from the discoveries of the Portuguese on this coast of Africa. They have carefully concealed the positive documents which they may have collected, lest the other nations of Europe should rival them in their commerce. We read in the Decades of Barros that they had much intercourse with the two kingdoms of Toucou- 
rof and Timbuctoo. It is not demonstrated that the first of these names is identical with Takrour,* and consequently this passage will not prove that the countries of Takrour and Timbuctoo are distinct.

In the time of Leo Africanus, who travelled in the early part of the sixteenth century, the prosperity of Timbuctoo had declined in favour of the town of Djenné, which is still, by the report of $\mathbf{M}$. Caillié, more considerable and commercial than the former city. According to Leo, the river which runs near Timbuctoo takes a westerly direction. "We navigated," says he, "coming from the kingdom of Tombuto, to the east, and following the course of the stream, towards the kingdom of Ghinea, and as far as the kingdom of Melli, which are both to the west of Tombo." This assertion is not confirmed by the French traveller. Even if we suppose that one of the two branches, which he saw near that city was a tributary, and not a derivative branch, and that he had not perceived the distinction, (which must appear very extraordinary), this hypothesis would be contradicted, since it was reported to him by the inhabitants that this arm rejoined the principal stream at some distance.

With the exception of Leo, (who was a Moor born at Grenada), and the Portuguese, concerning whom we

* This opinion is adopted by M. Walckenaer (Recherches sur l'Afrique sept. \&c. p. 32). 
have but uncertain accounts, transmitted by Marmol and Barros, the first European who reached Timbuctoo was Francis Paul Imbert, born at Sables-d'Olonne, in the native province of Réné Caillié ; his journey was anterior to the year 1670. He accompanied his master, a Portuguese renegado, sent to Timbuctoo by the governor of Tafilet. From the little that is known of his travels, we learn that the distance from Morocco to Timbuctoo is four hundred leagues, and that it is considered a two months' journey. This route was nearly the same as that followed by M. Caillié, at least as far as Tafilet: the time also is the same. Again, the calculation of four hundred leagues agrees very well with that of M. Caillié. Three other routes have been attempted by Europeans for penetrating to the centre of Northern Africa; that of the Senegambia, that of Tripoli, and that of Egypt and the Upper Nile. The first is certainly the shorlest; the second is full of obstacles; and the last, though the longest, will probably be one day preferred by the intelligent traveller, as the most instructive, the most fruitful in discoveries, and for other reasons. I say nothing of a fourth course, that of the Gulph of Benin, which at this time engages the attention of England, but which, notwithstanding the numerous rivers terminating in that part, seems to offer very little prospect of success. To penetrate into the interior by the Rivers of Senegal, Gambia, or Sierra-Leone, was the most natural enterprize, not only on account of the proximity, but also with a view to the necessity of tracing to its source that vast stream which runs near Timbuctoo : a question of no 
less importance than the problem of the sources of the Nile, and which is become almost as celebrated with the moderns, as the other was amongst the ancients. It is also observable that of forty-two European travellers, twenty-two are supposed to have taken this route, independently of six Europeans shipwrecked on that coast, carried into the interior by the Moors, and who have collected information respecting either Timbuctoo or other central countries, These travellers not having for the most part pursued the same track with M. Caillié, and an abridged history of their discoveries having been already compiled by $\mathbf{M}$. Walckenaer and other learned geographers, I consider it altogether superfluous to review them. The reader will have double cause to rejoice in the curtailment of these observations, and in being at the same time directed to such excellent sources of information. I shall only state, from these various authorities, the epoch and extent of the principal journeys, succinctly analyzing those which present a line of route crossed by that of M. Caillié, or which have something in common with it. The reader will thus have before him a striking picture of the several efforts made, with admirable perseverance, by Europeans, during the last two centuries and a half.

In 1588, Thompson..... reached Tenda. .... . by the Gambia.

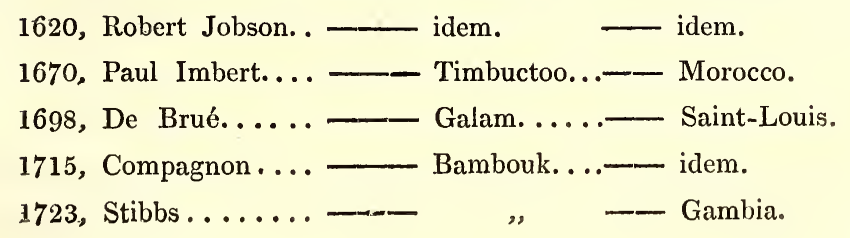


1731, Moore....... reached Bambouk.... by the Gambia.

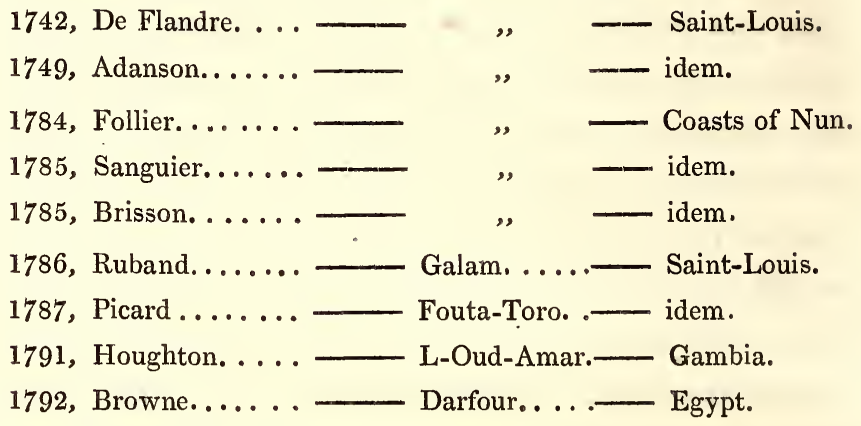

1794, $\left\{\begin{array}{l}\text { Watt. ...... } \\ \text { Winterbottom }\end{array}\right\}-$ Timbo..... Rio-Nuñez.

1795, Mungo-Park...- $\left\{\begin{array}{c}\text { Silla on the } \\ \text { Dhioliba }\end{array}\right\}-$ Gambia.

1798, Hornemann. . _- Nyffé. . . . . - E Egypt.

1805, Mungo-Park. .. - Boussa. . . . . G_- Gambia.

1809, Roentgen..... " _ - Magador.

1810, Robert Adams. . Timbuctoo...- $\left\{\begin{array}{l}\text { the western } \\ \text { coast of } \\ \text { Africa. }\end{array}\right.$

1815, Riley........ " " - idem.

1817, Peddie. . . . . . K Kakondy . . - Rio-Nuñez.

— Campbell. ..... _- Pandjicotte. .— idem.

- Badia. ...... " " - Egypt.

1818, Mollien. ...... Timbo...... Saint-Louis.

$\left.\begin{array}{l}1818, \\ 1819,\end{array}\right\}$ Gray...... F- Fouladou. .... Gambia.

- Dochard..... . Y Yamina..... i_- idem.

— Bowdich. . .... - Coumassie. . ._- Gold Coast.

- Ritchie...... T- Fezzan....-T Tripoli.

- Lyon. ........ , , - idem.

1820, Cochelet...... Ouad-Noun. .- $\left\{\begin{array}{l}\text { west coast } \\ \text { of Africa. }\end{array}\right.$ 
1822, Laing ...... reached Falaba.... by Sierra-Leone.

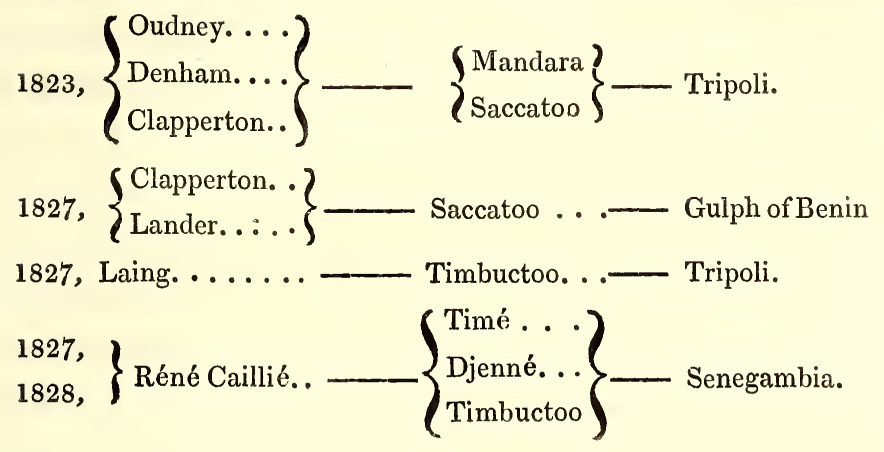

To this list may be added Ledyard and Lucas, in 1\%88, Nicholls, in 1805, Seetzen and Tuckey, in 1816, and P. Rouzée, in 181\%, who took different routes, and did not succeed in penetrating into the interior.

Twenty-five Englishmen figure in this list, with fourteen Frenchmen, two Americans, and one German : but there are few of them, alas! since Major Houghton, who have not fallen victims to their heroic devotion, in the midst of their career.

Before setting out on his great journey M. Caillié had visited the interior of the deserts frequented by the Brakna and Dowich Moors; he had also accompanied M. Adrien Partarrieu, attached to the expedition of Major Gray.

He then followed or traversed the route of Major Houghton, going to the Ludamar of Mungo Park, (or 
rather the country of Eli-Oud-Amar*) and those of Major Gray and Surgeon Dochard, the one to Falimé, the other to Yamina. But, as he kept no regular notes of his peregrinations in this portion of Africa, I have no means of comparing them with those of the three former travellers. It is otherwise with the routes of Watt and Winterbottom, who in $\mathbf{1 7 9 4}$ arrived at Timbo and Labé by the Rio-Nuñez; there they learnt that a four months' journey would lead them to Timbuctoo, by way of Belia, Bouria, Manda, Sego, Sousundou and Genati†.

On examining the general map of M. Caillié's travels Baleya, Bourré, Amana, Sego, Sansanding and Djenné, names very little differing from the former, will actually be found, in a line, not indeed perfectly direct, from Labé to Timbuctoo. With regard to the four months' distance, it is worthy of remark that M. Caillié was a hundred and seven days proceeding from Teleouel (nearly opposite to Labé) to Timbuctoo, following a rather more easterly course. In several other particulars the narratives of the two English travellers are in accordance with the observations of M. Caillié, such as the traffic in salt,

* According to the traveller Adrien Partarrieu, a man of colour, resident at Senegal, who was well acquainted with the languages both of Africa and Europe, and capable of making good geographical observations.

+ See Histoire complète des Voyages et Découvertes en Afrique, by Dr. Leyden, and H. Murray, French translation, vol. 3, page 173 and the following. 
and its being carried on men's shoulders, the position of Labé and Timbo with respect to Kakondy,* the state of agriculture, and the manners of the Foulahs.

The first journey of Mungo Park, in 1795, conducted him to Sego on the Dhioliba, and thence to Silla : these two places were left to the west of M. Caillié's route, as may be seen on the general map. The only doubtful question respecting the line between them arises from the considerable difference that exists as to the distance of that line from the ocean : but this question is very comprehensive, and embraces too many different points to be examined here. It may, however, be observed that the population assigned by Mr. Park to Sego (thirty thousand) appears somewhat large as compared with that of Jenné, Timbuctoo, and other towns visited by M. Caillié.

In his second journey, in 1805, Mungo Park reached the river at Bamakou ; at Sansanding he embarked upon it, in a canoe constructed under his direction, and followed it to Cabra, Houssa, and Boussa. Thus, from the branch which runs into it below Jenné to Cabra, the two travellers followed the same route, and navigated the same stream. Unfortunately Park's narrative breaks off at Sansanding, on the loth of November, at the moment of his leaving that town. There is however, a last piece of allthentic information on the 19th of November; this is a

* The position of Timbo should first be corrected from the observations of Major Laing. 
note addressed by Mungo Park to his wife. It is known that the bark which he contrived for descending the river was a sort of raft or flat boat, formed of two old canoes.

It cannot easily be credited that the traveller advanced upon the river at the rate of six or seven miles an hour as his journal indicates : it has been seen that the direct progress of M. Caillié on the Dhioliba was scarcely more than two miles an hour; in a different season it is true, and at low water. Mungo Park, according to his guide, perished at Boussa, four months after his departure from Sansanding, which account, unless erroneous would infer a stay either at Timbuctoo, Houssa, or Yaour.* It is not possible here to institute any comparison between the two narratives, and I think it superfluous to seek other points of resemblance; I confine myself therefore to the observation, that the map of Park's second journey aggravates the error committed in the first map, in placing the course of the Dhioliba too far eastward of the city of Timbuctoo. $\uparrow$ It is not consistent with my subject to enter into further particulars concerning that unfortunate expedition, with the commencement and issue of which every

* It has already been remarked (If an author may be permitted to quote himself) in the Réflexions sur l'état des connaissances relatives au cours $d u$ Dhiolibâ (page 23) that the catastrophe appears to have occurred about the 4th of January 1806. He set out from Sansanding about the 19th of November, his voyage therefore could only have lasted about forty seven days.

+ Compare the map of Park's second journey, in the "Journal of a Mission to the Interior of Africa," etc. London, 1815. 
one is acquainted; but of the most essential points of which all are equally ignorant, namely the navigation of the river above and below Timbuctoo, and all those observations that were undoubtedly made and written by the celebrated traveller on papers, that there is yet some hope of discovering.

Chronological order obliges me to pass from such a man as Mungo Park to the American sailor Robert Adams.* Notwithstanding the efforts of M. Dupuis, editor of Adims's narrative, and the real merit of the notes appended to it by that learned writer, the general opinion of geographers is opposed to the authenticity of these travels; and it is a remarkable fact, that it is least credited in his own country. Critical observations on this subject have appeared in the North American Review, from which we are compelled to conclude that the original declaration made at Cadiz by Adams before the American consul, totally differs from his recital, made in London, to $\mathbf{M}$. Dupuis. I am far from believing in the reality of Adams's travels in all their circumstances as described; but a com parison of them with those of $\mathbf{M}$. Caillié belongs to my subject. Robert Adams was wrecked on the coast of Cape Blanco, and was carried to Timbuctoo, where he says he remained five months. $\uparrow \mathrm{He}$ afterwards returned through Toudeyni, Oulad-Deleym, el-Thabla, Ouad-Noun, Mogador, Fez, Mequinaz, and Tangier. Even in his descrip-

* Otherwise Benjamin Rose.

† Nouveau Voyage dans l'Intérieur de l'Afriquc, fait en 1820, etc. translated from the English by the Chevalier de Frasans, Paris, 1817. 
tion of 'Timbuctoo, a striking contradiction occurs. "The city," he says, " is in a very level plain;" and yet two miles beyond the city, runs the river Marzarah, between two rather high-mountains. This river flows to the southwest, and is three quarters of a mile wide. He repeats elsewhere that there are mountains to the south of Timbuctoo, and says that sulphur is found there. None of these circumstances have been noticed by M. Caillié, who walked from Cabra to Timbuctoo, and who in thirteen days had abundant leisure to observe them. The city appeared to Adams as extensive, without being as populous, as Lisbon; but between two hundred and sixty thousand inhabitants and ten or twelve thousand there is a great difference. There are no mosques, says he, in Timbuctoo; M. Caillié saw three large and several smaller ones.*

Adams asserts that he saw a palace built of clay mixed with herbage, and other houses of wood or earth : the greater part of the houses, according to M. Caillié are of brick, and the king's palacet is nothing more than a small and extremely simple house.

Adams asserts that the men are tattooed; M. Caillié says nothing of the existence of such a custom at Timbuctoo: that there is not a man capable of writing; the new account frequently affirms the contrary: that many

* Such a change cannot have taken place in eighteen years.

$\uparrow$ See plate 6 , in this volume, and the explanation. 
elephants are to be seen there; M. Caillié scarcely saw traces of one during the whole course of his travels. Nevertheless these differences which may be partly attributed to his ignorance, as well as to a want of memory, are not sufficient motives for absolutely. denying the journey of Adams, or rejecting all the information which he procured. The same may be said of the words of the language spoken at Timbuctoo, which Robert Adams has given to the number of sixteen, eight of which are common to the Kissour vocabulary of $\mathbf{M}$. Caillié,* but totally differing from them.

Was it easy, in a country where so many different languages and dialects are spoken, to ascertain the genuine words of the Timbuctoo idiom? The words published by well informed travellers, such as Lyon, Bowdich and others, do not agree better with those col, lected by M. Caillié. If Adams really visited Timbuctoo, it is possible that he may have interrogated strangers instead of natives. + Major Denham alone till the present day has learnt the true words of this language. Other features again of Adams's descriptions are confirmed by certain Arabian travellers and geographers, even what he says of the river flowing in the neighbourhood of Timbuctoo. Yet, supposing him to have seen the river, which

* See below, Chapter II, und Nouveau Voyage, \&c. p. 79.

$\uparrow$ It has been already observed, that he gave five Arabic words, as those of Timbuctoo. Nouveau Voyage, page 175. 
is to the south, may he not have been mistaken as to the direction of the stream ? May it not be the second branch of the river, which M. Caillié saw at Cabra, and which at first runs towards the north-east? It does not however run two miles south of Timbuctoo, but five miles. The river, he says, is called Marzarah: and this name though unknown to M. Caillié, yet exists; and is the name also of a district cited above, after el-Edricy.*

Robert Adams is not incorrect in his journeys beyond Timbuctoo: 1st from this city towards the E. N. E., as far as the river mentioned above, where he arrives after ten days' journey; 2ndly from this point to Toudeyni, twelve or thirteen days' journey N. N. W. These distances and bearings agree tolerably well with M. Cailliés route from Timbuctoo to Telig.

Riley, the American, also wrecked on the west coast of Africa, and detained in slavery by the Moorish Chief Sidi-Hamet, gathered from the latter some correct notions relating to the city of Timbuctoo. According to him $a$ small river (it was then dry) runs near the walls of Timbuctoo, and a large river flows to the east at an hour's distance on horseback. This is undoubtedly the same with that of which he elsewhere speaks as the Zolibib, which is two hours' march to the south. The city is five times

* The substitution of Bahr zahara (river of the desert) for Marzarah, as proposed by M. Dupuis, appears improbable. See Rel. d'Adams, page 136 . 
as large as Soueyrah, situated in a vast plain, and built of stone, earth, and reeds. On leaving Timbuctoo, SidiHamet travelled fifty-five days towards the N. E., and eighteen to the north, before he arrived at Touat, and afterwards he proceeded to Fez. M. Caillié did not perceive the little river close under the walls of Timbuctoo; but what is said by Riley shews that it might be dried up. The great river at two hours' distance to the south, is evidently the Cabra branch, flowing between the east and north. The word Zolibib is unquestionably the same as Dhioliba. The situation of the oasis of Agably (or of Touat), is not consistent with the data by which I was guided in drawing up the general map, namely the astronomical observations made by Major Laing at Ainsalah.*

We have seen above that Major Peddie and Captain Campbell took the way of the Rio-Nuñez, to penetrate into the interior: the second alone was able to advance to within a short distance of Timbo; but he could not reach that place. Both swelled the list of victims to the climate and martyrs of science. Captain Campbell, and M. Caillié, as well as Watt and Winterbottom, travelled in nearly parallel lines : their accounts, far from contradicting, mutually confirm each other; but the marches of the French traveller present a multitude of instructive details, and local circumstances which the

* See below, page 217 , the analysis of the general map, $\$$ II, Art. 3. 
others had not the opportunity of observing. The rivers and rivulets crossed by these travellers, some of which flow northwards and fall into the Rio-Nuñez, and others south towards the district of Sousou, are distinguished. By combining the observations of all the four a complete idea may be formed of the tract which separates Kakondy from the Fouta-I)hialon and the mountains of Timbo.*

We are indebted to the expedition of M. Mollien for some interesting particulars of the unknowr parts of the Senegambia, and of the plain of the Fouta-Dhialon. Nothing was wanting to this expedition of discovery but mathematical observations, which it would be unjust to require from him who traverses, for the first time, unknown countries, inhabited by a fanatical population. Geography is a great gainer when it can obtain any positive information, either respecting the lines travelled over, with their bearings, or the relative situation of places, and their nomenclature; or even a view of the importance and population of the country, and the state of agriculture, commerce and industry. A learned geographer, M. Eyriés, has shewn the merit of M. Mollien's travels, and the acquisitions for which science is indebted to him ; it only remains therefore, for me to notice that part of his journey, which coincides with that of M. Caillié. Both crossed the Fouta-Dhialon, but in different directions. The first went from Labé to Timbo; the second

* See further on for what relates to the basins of the different rivers. 
passed between those two towns. Their lines of route intersected each other at a point nearer to Timbo than to Labé, but where there is no village; at least the list given by M. Mollien does not present, at the point of meeting which results from the construction of the two routes, any name in common with the much more extended list of M. Caillié. But the latter, in giving the position of Labé with regard to Teleouel, and that of 'Timbo with regard to Dité, will be found to agree with the itinerary of M. Mollien. In the list of the latter, we find indeed Cambaya and Bandeia; but Bandeia, placed far north of Labé, is a totally different place from Bandeya, which is south west of it. The same may be observed of Cambaya to the north and near Labé, while the Cambaya of $\mathbf{M}$. Caillié lies south-east of that place, and at a considerable distance. The description of the mountains, the cataracts or falls of rivers, the physical aspect of places amid those lofty mountains, (which in some respects may be called the Central Alps of Northern Africa), are features common to both narratives.* This spot, as will be seen farther on, is a line of division between immense streams which fiow from it in every direction. There is no less analogy between the observations of the two travellers

* From this lofty range the Rio-Grande and the rivers of the Timannie flow to the west and south-west; the Gambia, the Falemé, the Bâfing or Senegal, to the north; and the Dhioliba and its tributaries, to the east. It is probably connected with the mountains vulgarly called Kong, a word the true signification of which is mountain. 
respecting the Foulahs, the Mandingoes, and the various tribes inhabiting those countries.*

I now come to a traveller whose recent loss is regretted throughout Europe, the unfortunate Major Laing. A first journey made him advantageously known to the friends of science; a second rendered him illustrious; and both are more closely connected with that of $\mathbf{M}$. Caillié than all the expeditions I have just reviewed. It is fortunate for the French traveller, that he has these points of contact with Major Laing, especially since their discoveries upon comparison appear in perfect accordance. No one is ignorant that, in 1822, Major Laing, after having explored the Timmanie, the Kouranko, and the Soulimana, determined the situation of Timbo and Falaba, the sources of the Mongo and the Rokelle, and penetrated nearly to the source of the Dhioliba, or at least but a short distance from that point so long sought after. He assigned the position and elevation above the level of the sea of Mount Loma, whence this great river takes its rise; and he marked on his map the first part of its course northwards, to the extent of about twenty-five leagues. Amongst these observations are two which serve to verify those of the French traveller : the situation of Timbo and that of the Dhioliba. Now this confirmation, as a single glance at the general map of the travels will shew, leaves nothing to be desired. I placed Timbo there from the documents of the Major,

* Several points however of these narratives, which I cannot here pretend to reconcile, yet remain to be elucidated. 
and M. Caillié's route perfectly coincides. The French traveller met with the Dhioliba, for the first time, at Couroussa, and observed its course. This point and this course, from the mere construction of the new map of the route, are found to continue that traced by the English traveller. At the point of meeting, there appears to be a very small interval left, and I have therefore had no difficulty in supplying this hiatus. Henceforward our knowledge of the thirty-five or forty first leagues of the course of this great river may be considered as perfectly established.

The second expedition of Major Laing, as all the world knows, had for its object the city of Timbuctoo, which he endeavoured to reach by way of Tripoli, not across the Bornou, like his immediate predecessors, but by the direct route of the oasis of Agably. The work, which, in the course of this paper, I have had frequent occasion to quote, has made the reader acquainted with l'Itinéraire de Tripoli, de Barbarie à la ville de Temboctou, by the sheik Hagg-Cassem, revised by M. Delaporte, vice-consul of France; an itinerary which I congratulate myself upon having submitted, in 1818, to the Institute, since my learned colleague $M$. Walckenaer, declares that it induced him to favour the public with his Recherches géographiques sur l'intêrieur de l'Afrique septentrionale. This document places Timbuctoo at eightyone days' distance from Tripoli, and the oasis of AinSalah and Agably at thirty-three days, or three sevenths of the way. We are yet ignorant what observations 
Major Laing made on this route; we only know that he passed Ghadamès and Ain-Salah, and we possess his observation made in the latter place. This observation carries much farther west the position admitted on the maps ; but for several reasons I have felt necessary to make use of it: 1st, Major Laing proved himself a correct observer, in his travels in the Timannie; 2ndly, the situation of Timbuctoo, being more westerly than it has hitherto been considered, should carry with it that of the oasis of Touat, which is in the direct line ; 3rdly, there is nothing in the itinerary of the sheik HaggCassem, in opposition to the more westerly tendency of this line of route; 4thly and lastly, the computation of the day's journey appears to me too low, when reduced to fifteen geographical miles. The reasons, which induce me to estimate it at eighteen miles and four tenths, will be found elsewhere : it follows from this calculation, that the oasis of Touat should be brought nearer to the ocean. This result agrees with the more westerly position of the route from 'Timbuctoo to 'Tafilet, as shewn by the journey of M. Caillié. Till some of the papers of Major Laing are discovered, (and this hope is not altogether lost, since M. Caillié himself, in traversing the great desert saw a compass, and heard mention of a sextant which had belonged to him), it is impossible to make further comparisons between the travels of the French discoverer and the second expedition of the Major, although both resided in the city of Timbuctoo, almost in the same house, and though the latter nearly reached el-Arawan. 


\section{$\S$ II.}

\section{ANALYSIS OF THE ITINERARY MAP, AND OF THE GENERAL MAP OF THE TRAVELS.}

In constructing the maps here submitted to the reader, I was unable to avail myself of the information procured by our adventurer in his preceding travels, either in the Bondou, amongst the Brakna Moors, or amongst the people in the neighbourhood of Kakondy, the Nalous, the Bagos or the Landamas : these excursions present no continuous progress susceptible of being traced on a map. The fourth excursion alone, therefore, can enter into the present discussion, namely the great journey from the Rio-Nuñez to Tangier, commenced on the 19th of April 1827, and concluded on the 7 th of September 1828; I shall consequently confine myself to a mere glance at the former travels. The examination of this route will be divided into three parts.

1st, Journey from Kakondy to Timé, beyond the Dhioliba.

2nd, Journey to Djenné, and navigation of the river thence to Timbuctoo.

3rd, Journey from Timbuctoo to Arbate, and thence to Tangier.

I shall then devote particular attention to the general map of the travels. 


\section{ART. 1. \\ EARLY TRAVELS OF M. CAILLIF́.}

M. Caillié undertook his first excursion in 1819. From St. Louis, he repaired to Goree by the usual route, that is to say, he set out from Gandiolle, and followed the seashore without finding any opportunity for making new observations. The whole of this coast is perfectly well known from surveys by officers of the royal navy.

In 1819, he associated himself with M. Adrien Partarrieu, who was about to rejoin the expedition of Major Gray: the latter was then in the Bondou, reduced to grievous extremities, and he sent for M. Partarrieu, to bring him assistance, of which the expedition stood in the utmost need.* It is to be regretted that $M$. Caillié took no notes of his stages during this journey; the line of route crossed that of M. Mollien, as well as that subsequently followed by Captain Beaufort. The caravan passed Boulibaba, a town inhabited by the Foulahs, and the situation of which is unknown. This whole route indeed, deserves to be de-

* See the Voyage dans l'Afrique occidentale de 1818 à 1821, by Major William Gray, and the late Surgeon Dochard, Paris, 1826, translated by Mme. Ch. Huguet. Every one is acquainted with the unhappy issue of this mission, during which, however, interesting observations were made, equally worthy the attention of geographers and of philanthropists. 
termined and traced out on the maps: M. Caillié is amply justified in not having noted these particulars, knowing that M. Partarrieu was in possession of more accurate materials; whatever accounts or geographical observation ${ }_{\mathrm{S}}$ the latter traveller has transmitted being every way worthy of attention. Information is wanting respecting the desert space which on this side separates Cayor from the Ghiolof, respecting Potaco in the country of Bondou, and the whole transverse line from Gandiolle to Boulibané, the capital of that state. M. Caillié left Boulibaba for Bakel, and returned with his fellow-travellers to St. Louis by water, without having any new observations to make upon the road.

M. Caillié's third journey is more important, not only on account of its object, his initiation into the African manners and customs, and his preparation for an expedition into the interior and all its attendant hardships but more particularly for the curious descriptions which he has given of the journeys of the Moors in the deserts, of their stations hitherto nearly if not wholly unknown, and of the running or stagnant waters which he met with. It is to be wished that it had been possible to trace these positions upon the map; but I had not the means of fixing them with sufficient exactness. It will be remarked in reading this relation that the residence of the King of the Braknas is continually varying; he frequently dwells in the vicinity of the river Senegal and of the station known by the nanie of the Braknas. But in the wet season he penetrates far- 
ther into the desert; and when he removes his camp the entire population travels with him. The extent of space subject to this powerful tribe has been hitherto known only from east to west; but we learn from this account how far it reaches towards the north.

It would be desirable to geographers to learn the precise position of lake Aleg, that of the mountain called Ziré (a word which however is a generic term), and the limits of the great tribe of the Abou-sebas or el-Abousebah, the name of which is very differently and incorrectly written upon the recent maps : those who have supposed that the article formed part of the word, and that the termination might be retrenched have made out of it the word labos. Two terminations have been used sebas and sebah; the last only is correct.

I shall confine myself to a remark upon the relative position of Adar and the lake Aleg. According to our traveller, the distance from the one to the other is seven days' journey: how then shall we reconcile the situation assigned to Adrar, not far from Ouâd-noun, which is more than thirty days distant from the territory usually attributed to the Braknas? It would be requisite that this territory should extend northwards even to the extremity of the Sahara, which is contrary to our received ideas, but perhaps not to the fact.

M. Caillié, having returned in May 1824 to St. Louis, and despairing to obtain the means necessary for accomplishing his purposes, determined to remove to Albreda on the Gambia, and thence to Sierra-Leone, where he succeeded in collecting some resources, by availing him- 
self of his already acquired information. On the 22nd of May, 182\%, he embarked at Sierra-Leone for Rio-Nuñez, where he arrived on the 31st. By the 5th of August he was established at Rebecca (or Rabougga): where he employed himself at once in completing the observations and information already extant upon the neighbouring tribes, the Nalous, the Bacos, and the Landamas*, and in making preparations for his great expedition. He soon quitted this place for Kakondy : his activity, his perseverance, uncommon intelligence, and finally the fortunate circumstances of which he so skilfully took advantage, enabled him to set out on the 19th of the same month for Kankan. Ignorant as the world was of the situation of this town, it would seem that a happy foresight guided him in making choice of this direction, as in following it he crossed the rivers with which it was most important to be acquainted, in such a manner as to enable us tolerably well to assign their position and their distance from the ocean.

* See on this subject, the Nouvelle Histoire générale des voyages, \&c. published by M. Walckenaer. 


\section{A R T. I I.}

MAP OF THE TRAVELLER'S ROUTE.

General observation.

Before entering, in somewhat minute detail upon the examination of M. Cailliés routes, I should make an observation to warn the reader against the apparent differences which he may observe between the journal of the travels and the map of the route. To render this journal fit for perusal, and not to interrupt perpetually the description of places and people, it has been found necessary to retrench the number of distances and bearings, to such an extent that any one who should attempt to form a plan of the route by the assistance of the narrative alone would fall into serious errors: respecting this circumstance however the reader has been already cautioned in a note in the first volume. The construction of the lines of route upon the map which $I$ have designed is the result of all the indications given by the traveller, and which I have collected in the form of a table. It is also necessary to consult the following article, respecting the use which I have made of these materials, to render them accordant with anterior information and the positions already admitted as incontestable. 
The entire journey of M. Caillié, from Kakondy to Tangier occupied five hundred and eight days: from which, in order to obtain the days of actual travel, three hundred and one days of stationary residence in eighteen different places, must be deducted, which will leave two hundred and seven days' travel. I shall here subjoin a list of these places of residence, but it must not be inferred that the traveller had no convenient means of making observations in other stations, because it will be observed that when he arrived early at any place of consequence, the remainder of the day was spent there. 


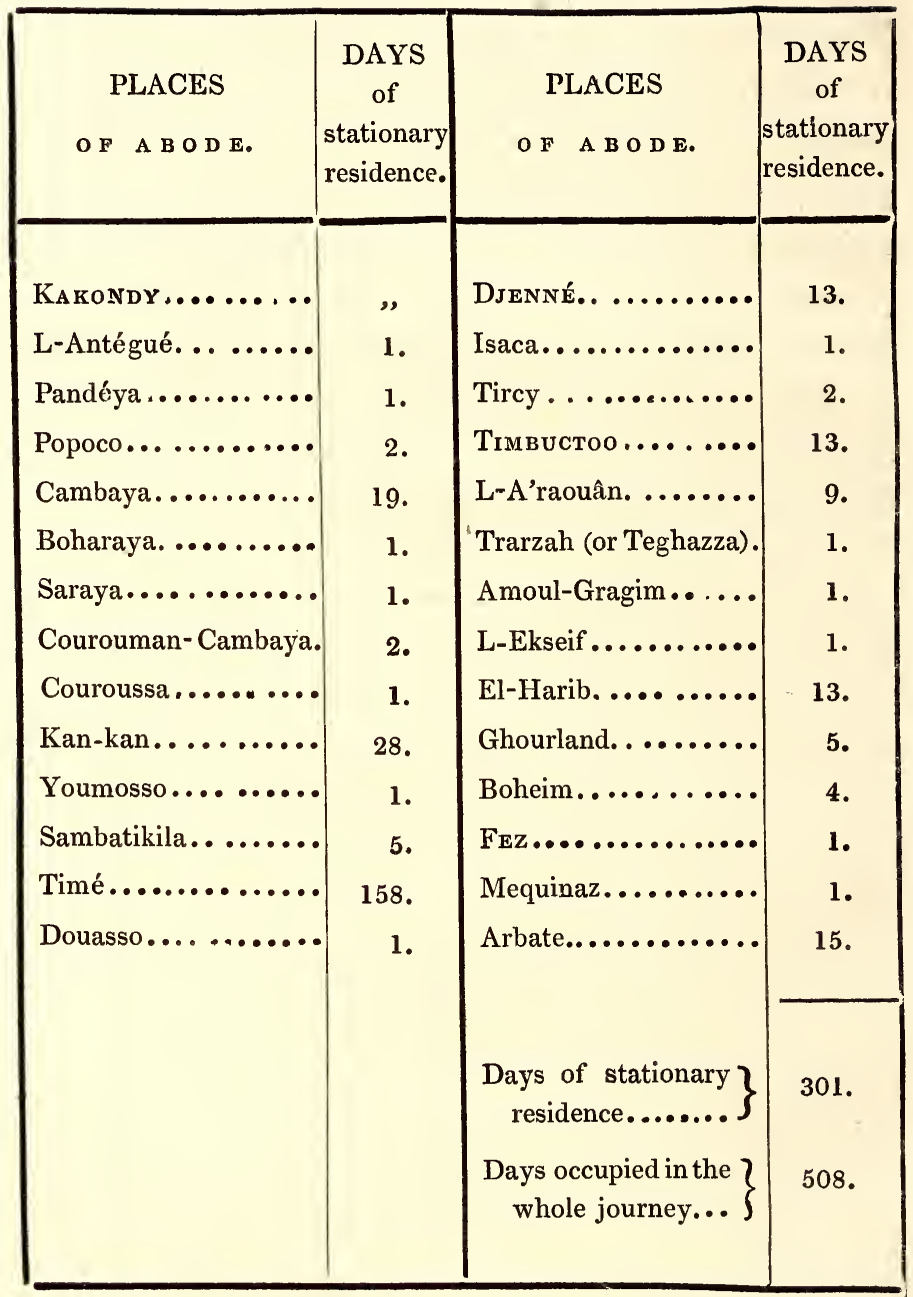

When it is proposed to offer a new map to the public it is an indispensable duty to submit to inspection the elements which form its basis, and not to ascribe to the 
work which results from them a greater value than appertains to the materials; these again have no other than what they derive, whether from the instruments and methods which the traveller has employed, or from the manner in which he has collected the observations and information which form the basis of his description. $\mathbf{M}$. Caillié was not provided with any astronomical instruments ; he had no watch, and measured the hour only by the height of the sun; but he possessed two compasses which were of great assistance to him. All his bearings were carefully noted by this instrument during the day, and by the stars at night. With regard to distances they were estimated according to several experiments made by himself at Sierra-Leone while preparing for his enterprise. He made a practice of walking over a certain space measured exactly in English miles and of observing the time he spent upon the road. It is thus that he calculated the number of miles in each of his marches from Kakondy to Djenné at three English miles an hour, or two geographical miles and six-tenths : as far as Timbo, however, that is to say during the first days of the journey, this number must be a little increased; this results from the situation of Timbo, as determined by Major Laing; and en passant we may observe that this part of M. Caillié's journey proves that the ancient position of Timbo, according to Watt and Winterbottom, is totally inadmissible. This rate of two geographical miles six-tenths an hour, or more exactly from two miles four-tenths to two miles six-tenths, can in general only be ascribed to isolated marches, and to cara- 
vans lightly laden. An hour's march of a lightly laden caravan seldom exceeds two geographical miles threetenths, and that of a numerous caravan heavily laden does not exceed a mile and a half, or a mile and three quarters*.

On quitting Djenné, M. Caillié travelled by water. The current of the river was slow, the obstacles arising from the faulty construction of the vessel, the ignorance and unskilfulness of the pilot, and the islands and sandbanks, reduce an hour's direct navigation to two English miles. Different causes producing, however, similar results determine the same value for an hour's march in the deserts between Timbuctoo and Fez. This number of two miles taken as an arerage for a long journeyt admits of almost all possible differences in the degree of expedition with which a caravan will move at different times : while it forms also the intermediate length between the progress of a caravan heavily and of one moderately laden, which was the case with the caravans which $\mathbf{M}$. Caillié accompanied from Timbuctoo, as may be seen by his narrative.

This same deficiency of space with a variation in the bearings, has caused the frequent breaks which I

* See below, Art. 3, remarks on the extent of an hour's and a day's journey in Northern Africa.

+ Ninety-six days exclusive of those of rest. 
have been obliged to make in the route on the itinerary map. The scale of a millionth part, adopted for this map, is perhaps too small to describe the details and all the angles of the route; I had, accordingly, at first constructed it upon a scale of double dimensions, but this development would have required too much space. 
FIRST PART OF THE JOURNEY.

The line of route in the first part of the journey depends essentially upon Timbo. 'This place is well worthy of attention both in respect to its physical geography and to the European relations with Africa. The English have always considered it as an important station for commerce, but it is not less deserving of study as the culminating point of this part of the continent. It is fortunate that several travellers have made efforts to determine its geographical situation. Major Laing has definitively fixed it in latitude $10^{\circ} 25^{\prime}$ north, and longitude $12^{\circ} 54^{\prime}$ west from Paris; its actual elevation above the sea remains to be correctly ascertained. I could not establish M. Caillié's route upon a better basis; and this I have done, by means of a direction which the traveller obtained from the village of Dité. There the inhabitants informed him that Timbo was at two days' distance in a certain direction, towards which he immediately applied his compass and found it to bear S. E. $\frac{1}{4}$ S. Now, we may observe (and it is a remark common to the whole interior of Africa), that the inhabitants are scarcely ever mistaken with respect to the bearings of places; their accuracy in this respect is surprising; it is the effect of habit and of a particular tact. Secondly, I subjected this line of route to the position of the town of Labé, which is tolerably well known though not so certainly as Timbo. Our traveller, when near Teléouel learnt that Labé lay N. E. $\frac{1}{4}$ E. at two days' distance. Another confirmation is drawn from the posi- 
tion of Cambaya, in respect to Timbo, which latter, according to the natives, bears W. S. W. at two days' journey from Cambaya. Here, then, are five points well connected together, Teléouel, Labé, Dité, Timbo, and Cambaya, forming a whole, the main support of which rests upon Timbo*. From the nature of these data I have had no hesitation in subjecting the route from Kakondy to them; and the result has been that the hour's march proves to be a trifle more than three English miles, which, for the commencement of the journey, is not extraordinary.

But, be this as it may, the construction of this route upon the itinerary map has undergone no reduction or modification, and I have confined myself to designing as accurately as the scale would permit, all the angles of this line, the rivers which the traveller crossed or had sight of, the different elevations of the soil with his estimate of them, and in fact all the variations of the ground which he has carefully noted.

At thirty-two miles from Kakondy is a fine river called Tankilita, a name which much resembles that of Tingalinta, marked in several maps at the same distance; $\uparrow$ and which word is perhaps pronounced Ten-

* The two days' journey in a mountainous country must necessarily be valued at less than eighteen geographical miles each.

+ See amongst others La Sénégambie pour servir à la nouvelle Histoire générale des Voyages de M. Walckenaer \&c. par M. Dufour, 1828. 
kalita; it is the same, according to the inhabitants, with the Rio-Nuñez; this stream, which flows to the north, would, in this case, be only the origin or principal tributary of the Rio-Nuñez.

Dther rivulets or rivers, as the Bangala, the Doulinca, and the Kakiriman, a large river in the neighbourhood of the high mountains of Antegua, on the contrary flow towards the south. The soil is chiefly composed of granite in this district and beyond it : the mountains are very high, steep and pointed; chains still increasing in elevation succeed each other; and there are among them mountains two thousand feet in height. All this country, bordering on the Fouta-Dhialon, presents an accumulation of obstacles, which are with difficulty surmounted; and yet men and even women, with heavy loads upon their heads, are continually traversing it. One of these mountains, the Touma, forms the limit between the Tenanka and the Fouta, and beyond it are the cataracts of the Cocoulo, a large and very rapid river. Thence we proceed to the Bâfing, the chief arm of the Senegal: it appears that its source is to the west of Timbo, and that its course is to the west and north, (and not to the east); this, at least, is the inference I draw from the new itinerary; and the north-easterly course of the 'Tankisso, which belonged to the bason of the Dhioliba, confirms this opinion.*

* It appears to me that M. Dufour, in his estimable work on Senegambia, restricts himself too sćrupulously to the details of $M$. Mollien's route, which nevertheless are very valuable. 
We afterwards descend into vast and very fertile plains, watered by the Tankisso, a large river, with steep banks, the Bandiegue and others less considerable, till we reach the principal river of this part of Africa, the Dhioliba.

On leaving the Soulimana the river takes a northerly direction, as I have said above, on the authority of Major Laing, but afterwards turns to the east. This bend is precisely given by a distance in the new itinerary. It may be observed that the river passes at one day's journey to the south of Saraya. This bearing is in perfect agreement with the map of Laing's journey to the Soulimana,* which will confirm if necessary the position of Saraya, and my plan of the route. It is known that the actual height of its source above the level of the sea, is, according to Major Laing, about sixteen hundred feet, or a hundred and thirty more than the source of the Rokelle.

It was at Couroussa, in the little country of Amana, that our traveller crossed it. Though so near to its source, it had already attained a breadth of nine hundred feet, and the moderate velocity of two miles and a half. At a short distance from this point, the Yendan, a large river, falls into it; farther on it receives the Milo, coming from the town of Kankan, and the Sarano, which waters the

* The Mandingoes place the Couranco, where Major Laing places the Soulimana, that is to say they prolong the Couranco to the N. W., towards the sources of the Dhioliba. 
rich plains of the Wassoulo. Proceeding towards the east, and leaving the Dhioliba to the left, the traveller reached Timé.

The situation of Timé is determined by two data: the one, that the march, throughout its whole length from Kakondy, was the same; the caravan was equally numerous, and if the country is less mountainous, the travellers were more fatigued, which forms a compensation: the other is furnished by the meridian altitude of the sun, twice taken at Timé, by means of the length of the shadow. Imperfect as this observation probably was, we ought to have some respect for it, when it coincides with the data of the itinerary; I shall soon resume this subject.

To conclude the examination of this first part of the itinerary, I shall make some remarks on the situation of the country, which appears to be the spot where the waters of this portion of the African continent separate. The first great line of partition is that which divides the waters of the Senegambia from those of the Soudan. The mountains which form it have their nucleus at Timbo, where their distinction into separate ranges is totally lost. Thence one range diverges to the north, and another to the east, and it is remakable that the divisions of the countries or states correspond with the physical regions. Thus in the country called Fouta-Dhialon, Timbo and its mountains are the sources of the Rio-Grande, the Gambia, the Falemé, the Senegal, \&c. The Soulimana 
and its mountains are the source of the Dhioliba on the one side, and the Rokelle and the Mungo take their rise on the other. From the backs of the mountains of the Fouta-Dhialon spring the tributaries of the Dhioliba, as the Tankisso (which cannot be an arm of the Senegal, as M. Caillié was informed): the spot where it rises is not far from Timbo, and the true point of division between the basons of the north and the east. Thus we have a proximate acquaintance with the relief of the country, which presents a satisfactory whole, where all appears to bear a natural connection. To this result M. Caillié's observations have materially contributed.

Besides the line of division of which $I$ have just spoken, there is another which separates the waters of the Senegambia from those of the Timannie; it is the result of an attentive examination of $\mathbf{M}$. Cailliés route. He crossed in fact two considerable rivers : the one, the Kakiriman, which is from seventy to eighty paces in breadth; the other, the Cocoulo, which is forty-five; and both very rapid. He saw them flowing to his right, that is southward, towards the bason of the Timannie.* Further on, that is after Popoco, all the rivers which he crossed flow to the left, towards the north, and into the Senegambia. Thus, between the route of M. Mollien and

* All the rivulets near Kakondy nevertheless flow to the north into the Rio-Nuñez; but their course is short; perhaps also, some of the succeeding ones fall into the Rio-Grande. 
that of M. Caillié, there must be a very elevated mountain crest, running from N. W. to S. E. and passing near the point of intersection of the two routes.

The names of the countries traversed by M. Caillié, in the first part of his travels, deserve a particular examination. According to the circumstantial description of the Baleya, it appears to me, that Major Laing has placed on his map a village of Beilia, where he ought to have marked and where in fact is, the country of Baleya. The Firia of the maps is the same with the Fryia or the Firya of M. Caillié ; the Sangaran is nearly where it has been placed upon the recent maps, but on both sides of the river. With respect to the Couranco, if $\mathrm{M}$. Caillié was rightly informed, it extends considerably towards the N. W., whereas Major Laing confines it to the interval between the rivers Rokelle and Camaranca, in the south. This country borders it should seem on the Baleya and the Soulimana. The true source of the Dhioliba is in the Kissi, to the south of Couranco, according to $M$. Caillié (or of the Soulimana, according to Major Laing). Thus the whole discrepancy between the two travellers is reduced to the lengthening of the country of Couranco; but, are the limits of these petty kingdoms well defined, and are the natives themselves fully agreed as to frontiers which violence is perpetually changing ? On many maps the names of Sangala and Couronia are to be found not far from Couranco and Sangara. I suspect they are doing double duty here, as in so many other instances in geography, either through the 
difference of the orthography or the negligence of the transcriptions. Is not Couronia altered from Couronca Couranco) and Sangala, by the frequent mutation of the $r$ into $l$, from Sangara ? The Wasselon, or Wassoulo, should be placed much nearer to the ocean, the incontestable consequence of $M$. Caillié's march; and already this example affords a presentiment of the fact as relates to the course of the Dhioliba and all the districts which it traverses. This river having also been supposed too much to the east by three or four degrees, the result has been the necessity of lengthening all the distances in order to cover the space between it and Timbo, and the constructors of maps have scattered over this space the names of countries and places, made all the positions too remote from each other, and transformed hamlets into towns and towns into kingdoms. They have not sufficiently remarked the custom common to almost all travellers of lengthening distances by an exaggerated estimate, and have neglected to make allowance for the frequent curves and inflexions of the line of route: a double cause for throwing into the interior many countries much nearer to the sea than they are believed to be.

This want of exactness in the compiling of itineraries, or in laying down those itineraries upon maps, is no novelty in geography; the Ancients have furnished many examples of it, and the maps designed after the positions of Ptolemy are nearly all tainted with this defect; I shall mention Arabia alone as an example. But I must here 
terminate this short digression, the subject of which would almost furuish matter for a book equally useful and instructive. I also pass over many names of countries with which M. Caillié has made us acquainted, and which will figure for the first time upon the map of Africa, and many more which are already known, and the existence of which is now confirmed by authentic testimony. 
SECOND PART OF THE TRAVELS.

The largest portion of the space between Kakondy and Timé may be regarded as an entirely new acquisition for geography; the same remark applies to that which we are about to run over with our traveller. We must not regret that he abandoned the banks of the Dhioliba, and that this circumstance deprived us of information concerning the banks of that river from Couroussa to Djenné; we are indemnified for this loss by his discoveries respecting countries of which we have hitherto been utterly ignorant. Moreover, had he passed through Bamacou, Sego, and Sansanding, he would not have had time to sojourn in them so long as Mungo Park did: he might, perhaps, even have been recognised at Sego, and like Dochard have been detained. Leaving the river far to the west, he became acquainted with the tributary streams which traverse the triangular space comprised between Couroussa, Timé, and Djenné, and with all the positions of this vast tract. He also acquired information concerning the positions situated near the rivers, and of all the towns of any importance, by the attention which he paid to inquire their distance and direction at different points of his route.

I have already observed that, the route from Timé to Djenné having been performed under the same circuin. 
stances as the preceding, the estimate of three English miles an hour applies to this line of road; I have therefore admitted this with M. Caillié, and I have had the satisfaction to see that, in forming this line, without any alteration, upon the distances and bearings as he has given them, the latitude of Sego would remain very nearly the same as that which results from the observations of Mungo Park. made in this vicinity.* But this point remains for future examination, when I shall discuss the situation of Timbuctoo. Thus the delineation of this portion of the itinerary has not presented any great difficulties. Some topographical circumstances relating to this extent of country merit observation.

Beyond Timé the traveller proceeds for two days more towards the east; he then turns to the (magnetic) north, and continues afterwards in nearly the same direction, which ought to be borne in mind. There are high mountains of granite at Timé, and again at four days' distance, after which the ground subsides and becomes level. The sand is succeeded by a fertile soil, furrowed by the frequent streams running westward towards the Dhioliba, amongst others the Bagoe, a navigable river, and the Couara-ba. Tangrera, near the commencement of this line, appears to be a large and very commercial town; this point is placed, according to the journal to

* Sami to the west of Sego, $13^{\circ} 17$ north, second journey of Mungo Park, Journal of a Mission, \&c. London, 1815, page 149 and 150. 
the E. N. E. of 'Timé, (east by the compass), but not ten days to the east as appears by the journal.* At Tiara a part of the caravan directed their course upon Sansanding, and to the N. W., according to M. Caillié (the line traced on the map gives the true N. N. W.) ; agreeably to the information which he obtained at Badiarana. Caya is nine days to the north, and Sego nine days farther on; now Sego (as it is placed upon the map, as I have elsewhere said) + is situated due north by the compass, with respect to Badiarana; but the eighteen days' journey, if they really exist, must be very short, occasioned probably by the stagnant waters, and other obstacles, which render a winding course necessary. The situation of Cayaye is determined by its bearing upon Couara, five days to the N. N. W., which places it, as it should be, half way upon the road between Badiarana and Sego. This spot, Couara, doubly merits our present attention. I have had occasion, in another work, to remark that this is a generic word, the sense of which is analogous to that of river. Here we see beside a village of this name a pretty considerable river called Couara-ba, that is to say river-river; we have some examples of a like denomination in $B a-b a$, and other names of the same kind; an additional reason for not identifying rivers and currents on account of the similitude of their names, because it is above all things neces-

* It is nearly due N. E.

+ See, farther on, the tracing of the course of the river. 
sary to know whether these names are generic terms, or individual appellations.

In the second place, the Couaraba runs across a country through which, according to the map of Mungo Park, a river called Banimma passes, parallel with the Dhioliba ; this would appear impossible since the Couaraba falls into the latter stream, if we may believe the report of the inhabitants.

This portion of the itinerary furnishes data for the site of a country and even of a town called Kong, placed at a considerable distance in all the maps. The bearing of a line directed thither from Douasso is between S. S. E. and E. $\frac{1}{4}$ S. E. by the compass, which is in fact due south; so much for its longitude : but a distance of forty-five days' journey would carry it much too far to the south; doubtless the soil is very mountainous upon nearly the whole road, and the journeys very short. If we stop at the seventh parallel north, we shall make each day's march but seven or eight geographical miles, including the windings of the route.

Still proceeding northward, the traveller crosses large open plains and rich countries, bounded on the left by swamps, lakes, or ponds, which indicate the neighbourhood of a large river. At length he reaches its banks at Galia, opposite to Djenné, at ten miles distance. Before we enter this capital, let us examine some important geographical positions. Nothing could be more obscure than 
the situation of Bouré; we were ignorant whether there existed a town of this name, and even what was the site of the country of Bouré : in the maps we shall find differences of several degrees. M. Caillié did not visit Bouré ; but, in throwing together all the particulars which he collected, I find sufficient data to determine the situation of this town; for there is a town, and a very important one, on account of the vicinity of its rich gold mines, and the commerce of which it is the centre. Bouré stands upon the left bank of the Tankisso, a large tributary, as I have before said, of the Dhioliba, and at three quarters of a day's journey from the latter in a direct line, or one day's above the confluence. These particulars which agree well together, were furnished by various persons in various places. Moreover the position of Bouré is given by its distance from Kankan; and its bearing, namely, four or five days to the north, $\frac{1}{4}$ N. E., in descending Milo. Finally, as a fourth testimony, we learn that Bouré was five days' march from Couroussa, descending the Dhioliba in a canoe, and afterwards ascending the Tankisso.

Bamakou is known to us from the second journey of Mungo Park; but its actual situation should be considerably further to the west: the information obtained by $\mathbf{M}$. Caillié, and the construction of the map, place this town at about the tenth degree of longitude west of Paris, and in latitude eleven degrees forty-five minutes. The idea of forming an establishment there, is founded upon a real knowledge of the country; it was 
long ago suggested in memorials submitted to government, pointing out its advantages. The documents of M. Caillié confirm the possibility of the scheme at the present time. He thinks that from this point it is eight or ten days' journey to the nearest point of the Senegal. Now, it appears, from the map, that, by ascending the 13âfing, as far as thirty leagues above the first cataract of Felou, we should be seventy leagues in a direct line from Bamakou, which agrees very well with what has gone before ; this, however, is not the place for examining that question. 
OBSERVATIONS ON THE COURSE OF THE DHIOLIBA AS TRACED FROM COUROUSSA TO SEGO AND DJENNÉ.

The course of the river, from Couroussa to Sego, as I have traced it, deviates from the hitherto received opinions ; ${ }^{*}$ and I am bound to justify so material a change, when submitting it to the judgment of geographers. In laying down the routes of M. Caillié, I was not prepared for such a result, or rather $I$ was apprehensive of finding former conjectures relative to the much more westerly position of the river, and of the towns through which it flows destroyed by actual observations, as an illusion is dissipated by the clear light of truth. It has however proved quite otherwise, and this opinion was far from rash. In fact, beyond Couroussa the river runs due N. E., then eastward, and afterwards for a great distance to the north, instead of pursuing invariably an eastern direction as marked upon the maps. But on what is this latter direction supported? On what foundations does it rest? It has no other cause than the position arbitrarily assigned to Timbuctoo, much too far east, much too far from the mouth of the Senegal. On the more modern maps attempts have, it is true, been made to remove this position farther west; the necessity of bringing it nearer

* It is the same with that from Djenné to Timbuctoo. 
to the ocean has been felt, * but it has not been advanced far enough, and has still been retained in nearly the same parallel, instead of being brought at the same time farther north.

If the objection be admitted that M. Caillié has carried his route by water too far west, the result would then be that his route from Timbuctoo to $\mathrm{Fez}$ must have been carried too far east: now these two results are opposed to each other, since it is the same line of route, and the same bearing, which lead from Couroussa to Sego, from Sego to Timbuctoo, and from Timbuctoo to Fez.

One powerful consideration is that $M$. Beaufort has fixed and ascertained the position of the town of Elimané, eastward of Bakel, by a great number of observations; this is the present capital of Kaarta. From that place travellers are daily going to Sego; our unfortunate countryman was himself on the point of proceeding thither, and would have done so but for the destitution caused by the pillage of which he was a victim, and which compelled him to turn back. He was then told that Ségo was only at ten days' distance; that the bearing of Elimané with regard to Sego was E. S. E.; and

* M. Walckenaer, as I have elsewhere said, was among the first to acknowledge the necessity of this alteration. See Recherches, \&c. See also Vol. II, of the Mémoires de la Société de Géographie, and its Bulletin or Recueil périodique. 
that these days' journeys were journeys on foot. Let us work on these data, and see whether they confirm the course of the river drawn from the itinerary of M. Caillié.

Can these days' journeys be computed at more than twenty-one geographical miles? This can scarcely be admitted; but should they even be extended to twenty-two miles and in a direct line, it would be on the whole two hundred and twenty miles, which in the above direction would not reach the ninth meridian west of Paris.

While M. Caillié was at Kiebala, he was told the distances and bearings of Sego, which differ very little from the position resulting from that of Elimané in the opposite direction; and if the river was here carried eastward, as it is found in all the maps calculated from Park's travels, there would no longer be any agreement between these two different sources of information. If, on the contrary, these respective data are preserved, they naturally harmonize, and the northerly course of the stream is confirmed.

Besides, the latitude of Sego, although not yet observed, cannot greatly differ from that of Sami, which is near it: the observation there made by Mungo Park gives thirteen degrees seventeen minutes, and this is perhaps, a little too northerly. The approximative position of Sego, resulting from various data, and which $I$ have adopted as a medium, would thus be, latitude thirteen degrees; longitude, nine degrees west. 
Sego, according to the itinerary, lies due north by the needle of Badiarana, that is north seventeen degrees west. This direction exactly passes through the position which I have assigned to Sego, from the observation of Sami, by Mungo Park.

The bearing of Sego is likewise precisely indicated by the N. N. W. line of the compass, drawn from Saraclé.*

The course of the Dhioliba, from Sego to Jenné, west and east, and the position of Sego, are still more strongly confirmed by data with which the traveller was furnished at Bamba. Sego is three days' journey N. W. of that place; and at noon on the fourth, the city of Sego is reached: these are long days' journeys. The proportion of three to four, or rather of three to three and two thirds, will be actually found as I have traced it.

Lastly, it is elsewhere expressly said, that Sego is five days west of Jenné ; the new map gives W. $\frac{1}{4} \mathrm{~S}$. W. All these data, it is plain, perfectly coincide; and although they are not authenticated by a single good celestial observation, yet they agree too well together to allow one to venture upon deranging the whole itinerary of our traveller, and carrying the city of Sego and with it the

* The journal shows four days' distance ; these must be days of twelve leagues : there are actually eight ordinary days' journeys with the windings. 
whole course of the river, two or three degrees farther east, when besides there exists no observation whatever, either geographical or astronomical, for carrying the river and its towns farther into the interior of the continent.

The position of Djenné, the arms of the river by which it is surrounded, its situation in a large island apart from the Dhioliba, the stream which branches off in the neighbourhood of Sego, and rejoins the river at Isaca, four days further on, are so many circumstances all equally new, and which tend greatly to modify our previous notions. Looking at this complication of details, the obscurity and contradictions contained in all the accounts of the negroes on the subject of Djenné may be easily conceived; but, upon an attentive study and careful comparison of the different data, we arrive at a tolerably just idea of these localities : the reader will judge whether I have attained this object in the course of these observations and in the drawing here submitted to him. Unquestionably, there yet remain many circumstances to be learnt relating to this double branch of the Dhioliba, the true form and actual extent of the island of Djenné, and its double or perhaps triple communication with the branches of the river; for every step yet gained in our acquaintance with this mysterious river seems to throw us to a greater distance from the ultimate object: it is, therefore, to confess the truth, nothing more than a slight sketch that I have presumed to delineate; time will rectify our yet imperfect notions, and complete the observations 
of our indefatigable traveller, when the use that I have made of them may be judged of. M. Caillié presumes the island of Djenné to be eighteen miles in circumference; but the construction of the route and the general appearance of the map induce me to believe that it is of greater extent: I also suspect, that the junction of the island with the western branch of the river cannot be seen from Djenné, but only its junction with the eastern branch; this would be a natural consequence of the westerly situation of Sego, with regard to Djenné. For the rest, I refer to the observations in the following article, that this discussion may not be prolonged here.

I shall not stay to inquire how it happened that Mungo Park knew nothing of a second branch of the river, when he procceded from Sego to Silla. I shall likewise abstain from entering into further developments respecting the course of the Dhioliba beyond Djenné. The narrative furnishes ample details, not less instructive than new, respecting the course of the river, its depth, its immense width in some parts, to the extent of half or even a whole mile. One of the most interesting points of this route by water is the great lake Debo, or Dhiebou, which M. Caillié met with half-way between Djenné and Timbuctoo. I cannot help thinking that this lake is the same which figures on the maps under the name of Dibbie, but with a widely different position, form, and extent.

The enthusiasm of our traveller at the sight of this 
sea of fresh water must appear excusable to every one, and his eagerness to take possession, in a manner, of the spot, on behalf of his country, by giving names to three islets situated in it, cannot but be generally approved. Twenty three years earlier, Mungo Park had accomplished this same navigation, perhaps, had also given names to these little mediterranean isles. Who, either in France or in England would have blamed him for this national feeling, had the account of his discovery reached Europe?

The lake has two divisions, one eastern, the limits of which may be seen, the other western, extending beyond the reach of sight. M. Caillié is ignorant whence this mass of water proceeds; is it from a tributary, or is it on the contrary an efflux from the inundations of the Dhioliba? This geographical question, on many accounts an important problem, remains then in obscurity; further on I shall offer a rather probable opinion*.

To the east of this lake are sands and sterile hills; to the west, it is lost in vast marshes; the navigation of the latter division must be extremely difficult. Passing from Djenné to Timbuctoo, the traveller navigates the eastern division of the lake, keeping close to the right bank.

Below the lake (on the map) a winding of the river 
will be observed, which perhaps appears forced and unnatural; it results from the lines of route as noted down and the difficulty of substituting any thing else has alone determined me to retain it, although doubtful of its accuracy : an error, however, in this tracing will have little influence on the general result.

In approaching Cabra, the port of Timbuctoo, M. Caillie perceived to the right a large arm of the river, running E. N. E. and he continued to navigate the other, holding a north-west course. He was informed that the latter rejoined the first at some distance; but this important fact has not been verified by any European eye; the traveller could not have ascertained it, without repairing himself, at considerable risk, to the point of junction. As for the inhabitants, perfectly indifferent as to obtaining or transmitting intelligence of this sort, they spoke very vaguely to him on the subject. The problem, therefore, of the ulterior direction, and of the final termination of these branches of the river, is yet to be resolved; I defer this discussion to a subsequent article*, as well as the particular question of the situation of Timbuctoot; and shall conclude this with repeating, that the itinerary from Timé to Galia, and from Galia to Timbuctoo, has been framed on the calculation of two miles an hour.

* See $\S$ V. farther on. $\quad+$ See Art. 3. 
THIRD PART OF THE TRAVELS.

The progress of $\mathrm{M}$. Caillié through the desert has also been estimated at two miles an hour, at least as far as Tafilet, and that for reasons explained at the beginning. The principal interest presented by this part of the route consists in the exact information it contains of the wells and stations to be met with amidst this ocean of sand. Science is indebted to $\mathbf{M}$. Caillié for numerous and correct notions of these vast solitudes, which travellers cannot confront without consternation. Thus, we knew the spot called el-Araouan only by the wells found there, as a place at which the caravans usually fill their waterskins; but our traveller informs us that it is an important town: seeing it thus surrounded on all sides by the deserts, we are the less surprized at the situation of Timbuctoo in the midst of the sands.

The wells of Telig are remarkable for the vicinity of granite mountains, and for the neighbourhood of Toudeyni, which, in all the maps, is carried far to the west of the line between Timbuctoo and Tafilet. M. Caillié's description leaves no room for supposing that he is treating of some other place of the same name, since this city is well known to be a great mart for salt. I pass over in silence the immense banks of moving sand, and the rare accidents of the soil, which scarcely vary throughout this long tract of road, the dreary unifor- 
mity of which is interrupted only by the wells. Beyond the wells of Mayara appear the last branches of the chain of Mount Atlas. The granite shews itself at first in fragments and hillocks, afterwards in high hills and steep mountains. 'Twelve days' journey beyond el-Harib, we enter the district of Tafilet. Here the report of $\mathbf{M}$. Caillié is widely different from the received opinions : 1st. He heard nothing of any town of Tafilet, it is merely, he says, the name of a country. It is nevertheless possible that a town may have heretofore existed there, and have disappeared like so many other towns of central Africa. I observe in the travels of Ebn-Hassan from Fez to Tafilet, quoted in the Recherches sur l'Afrique septentrionale ${ }^{*}$, \&c. that the territory only of Tafilet is mentionea and not the town; which would support the account of M. Caillié. 2ndly. This country is much nearer to the meridian of Fez than it is marked on all the mapst. 3rdly. It is farther north

* See pages 457 and 464 .

$\uparrow$ In the map which accompanies his work, M. Walckenaer places Tafilet about $5^{0}$ east of Morocco; but M. Lapie, in the map to M. Cochelet's travels makes it only 3 degrees and a half distant. This is also the difference of longitude which results from the route of $M$. Caillié as tracedby me, the positions of Morocco and Fez being moreover precisly known. The whole eastern part however of the empire of Morocco presents difficulties and uncertainties, which cause the necessity of new observations to be sensibly felt.

$\ddagger$ May not the too great remoteness of Tafilet from Fez arise from the custom of which I have spoken, which always exaggerates itinerary distances? 
informs us, is the principal place in this territory; near it is a place called Afilé, and another of the name of Boheim*, besides Ressant, the residence of a governor under the Emperor of Morocco. M. Caillié mentions another position unknown upon the maps; a large town called Rauguerute or Rogrut, S. S. E. from Morocco.

The narrative presents but few details concerning the crossing of Mount Atlas; it is not a matter of surprize that, after so many fatigues and perils, our adventurer should be impatient to reach the end of so long a journey. However, I observe in this part the course of a little river or brook, called the Guigo, flowing from Soforo (or perhaps from beyond) towards M-Dayara, and probably as far as Tafilet. Upon carefully examining the traveller's route, we perceive that he first saw the Guigo, or had some knowledge of it, between Rahaba, and L-Eyarac, afterwards at Tamaroc, and Kars; that he crossed it at L-Eksebi; and that the river fertilizes the environs of N-Zeland, L-Guim, Guigo, and Soforo. The water-mills which our traveller saw at Soforo again announce the presence of the same river. Thus the part of its course with which we are acquainted will be at least fifty leagues in length and probably much more. I do

* May not the word beheim which in Arabic signifies cattle be here mistaken for the name of a place?

vol. II. 
not know whether it passes to el-Fez, where however several different rivulets are seen.

Neither was the journey across the Sahara altogether unprofitable with regard to our knowledge of the oases and of the stations which it contains. The distances of these places from the several points of his route were reported to our traveller; and these distances are very different from those previously admitted: but are there two accordant testimonies concerning these positions ? Each caravan and each tribe makes a different estimate of the intervals; and if, to the actual mistakes which the Moors and natives may commit, the errors in which they are interested be added, what a source of uncertainty will these present! Therefore, though I have fixed upon the general map the points of Tychyt, Oualet, Ouadan or Hoden, Ouad-Noun, - \&c., according to the indications of M. Caillié, combined with other documents, I consider them as very uncertain. Oualet, says our traveller is at ten days' distance from el-Araouan, to the west, fifteen north from Sego, and eighteen from Ouadan : this point falls near nineteen degrees of latitude and nine degrees forty minutes longitude west from Paris : the three lines meeting at nearly the same point. But if it agrees with the three data given above, it is at variance with the situation of Oualet, as hitherto admitted, either from Mungo Park, or the testimony of the natives. It is perhaps another place named Oualet, not that intended by Mungo Park. Can it be the Gualata of Leo 
Africanus ? but his description suits this no better.* In this case Gualata would be much farther to the south than is generally supposed. It is however certain that geographers cannot confound the Walet of Mungo Park with Gualata.

Although M. Caillié has not mentioned Agably which is believed to be the chief place of the oasis of the Touats, I have been obliged to insert it in the map, because the traveller gives a position called Touat much nearer to the route from Timbuctoo to the Tafilet. It is not surprising that several places should be so called, because the wandering tribe bearing this name occupy a considerable portion of the great desert, from the south of Morocco to beyond Agably. Besides, the situation of this place, which could not have been brought within the limits of the map, if we were to adopt the mere reports of the Arabs, to which geographers have had recourse, falls there, on the contrary, according to the astronomical observation of Major Laing, who fixes it much farther to the west. This observation is published, for the first time; I owe it to my learned friend Captain Sabine, himself united in the most affectionate intimacy with the unfortunate traveller, who transmitted it to him after sustaining a first attack on leaving this oasis. Nor was it at Agably that Major Laing made the observation,

* About 300 miles south of Nun, 500 north of Tumbut, and 100 from the Ocean : it is evident that no point can fulfil all these conditions. 
but at Ain-Salah, belonging to the same canton and at two days' journey from it; this place is cited in all the itineraries between Tripoli and the western Soudan. According to the Major its situation is twenty nine minutes west of Paris, and twenty-seven degrees eleven minutes thirty seconds north latitude. Notwithstanding the difference between this and the situation allotted to this town upon all the maps, I have thought it right to enter it in the general map of the travels.

The other places of the Sahara, such as Akka, Tatta, el-Kabla,* for want of new data, have been fixed from a comparison of those upon which the map of M. Walckenaer, or those of Messrs. Lapie, Brué, Berghaus, \&c., were formed. With respect to the names of tribes and colonies, I have endeavoured to place them with all possible exactness, and have been obliged to differ from several recent maps in other respects very valuable.

To the right of his route, and in front of el-A'raouan, M. Caillié heard of an important situation, that of Sala; but the accounts were too vague to be compared with the descriptions of the Arabs.

I shall finish the examination of this third part of

* Perhaps el-Quebly تهب signifying which is to the south, should, it is probable, be erased from the maps. 
the travels by the general list of the wells and stations of the desert on the line from Timbuctoo to $\mathrm{Fez}$; which line appears to be the most advantageous and the shortest, because it is the most frequented. It seemed to me that the collection of all these names into a single table might be of some utility. It will be remarked that Toudeyni does not appear in this list : may not this place be without water fit for drinking? and has Telig succeeded it as a more convenient station for caravans? I submit this doubt to the reader. 


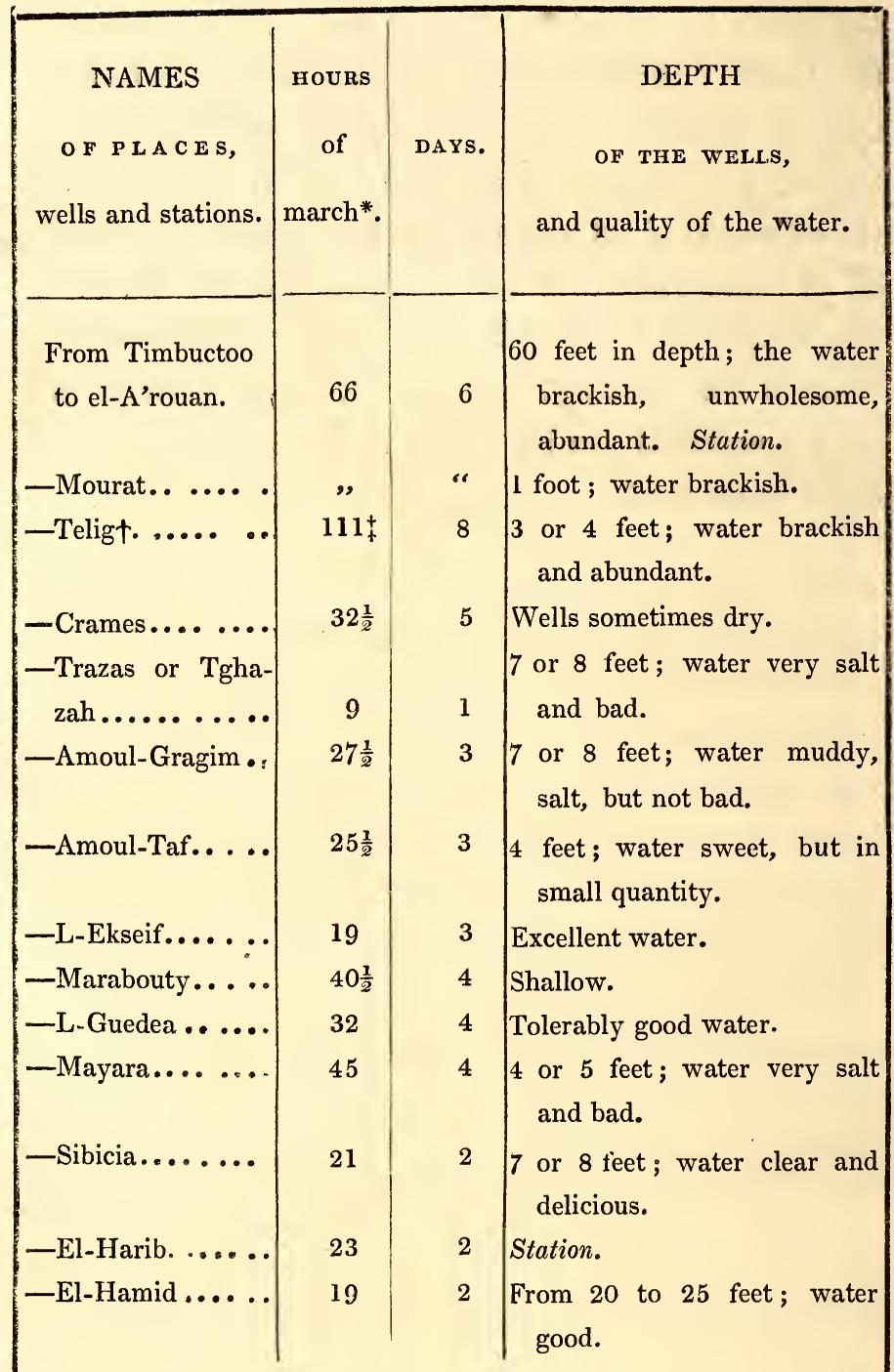

* For caravans moderately laden, see observations below.

+ Toudeyni is at the distance of one day's journey.

$\ddagger$ There is reason to believe that the caravan rested several times during marches of more than twelve hours. 


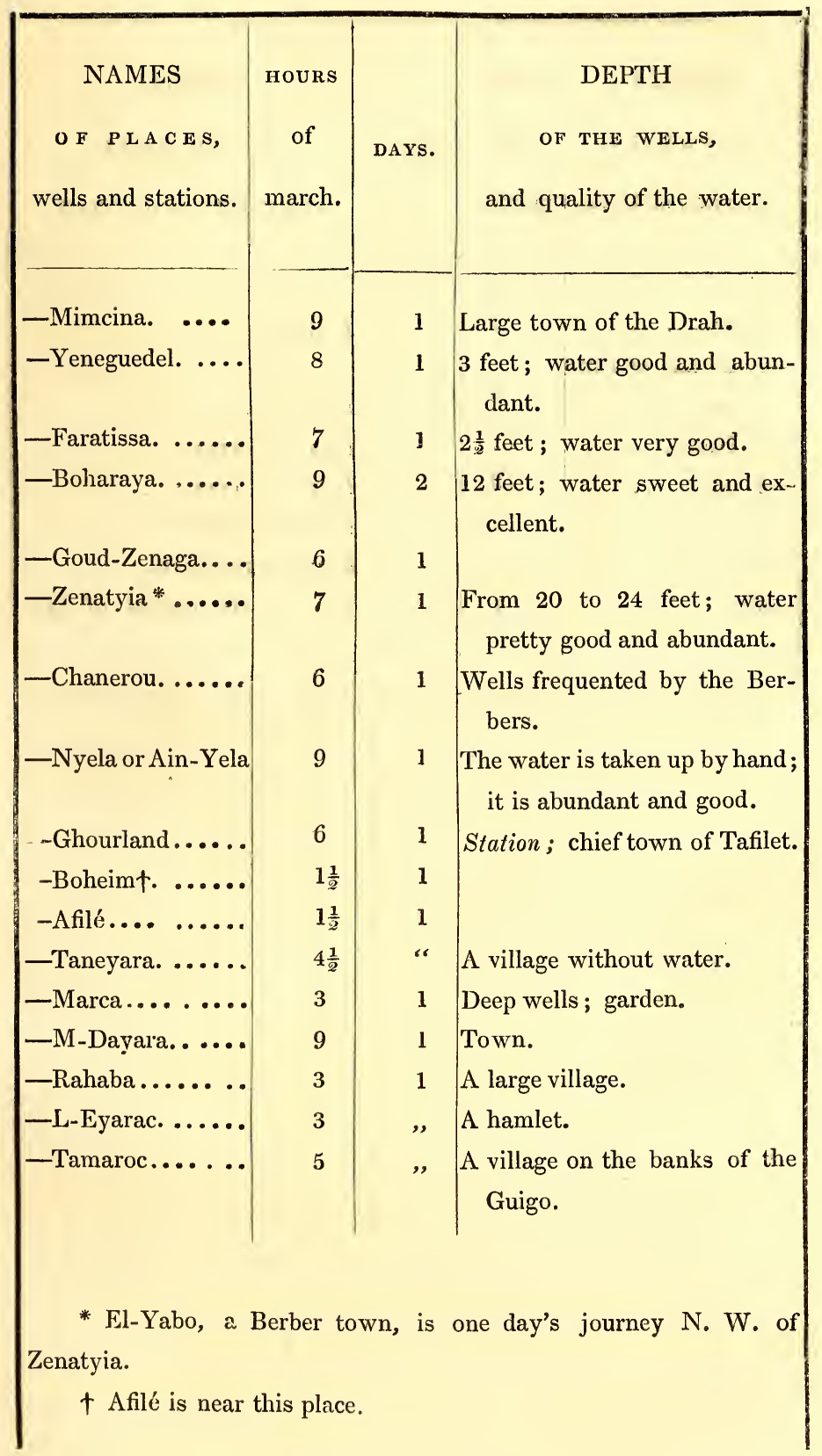




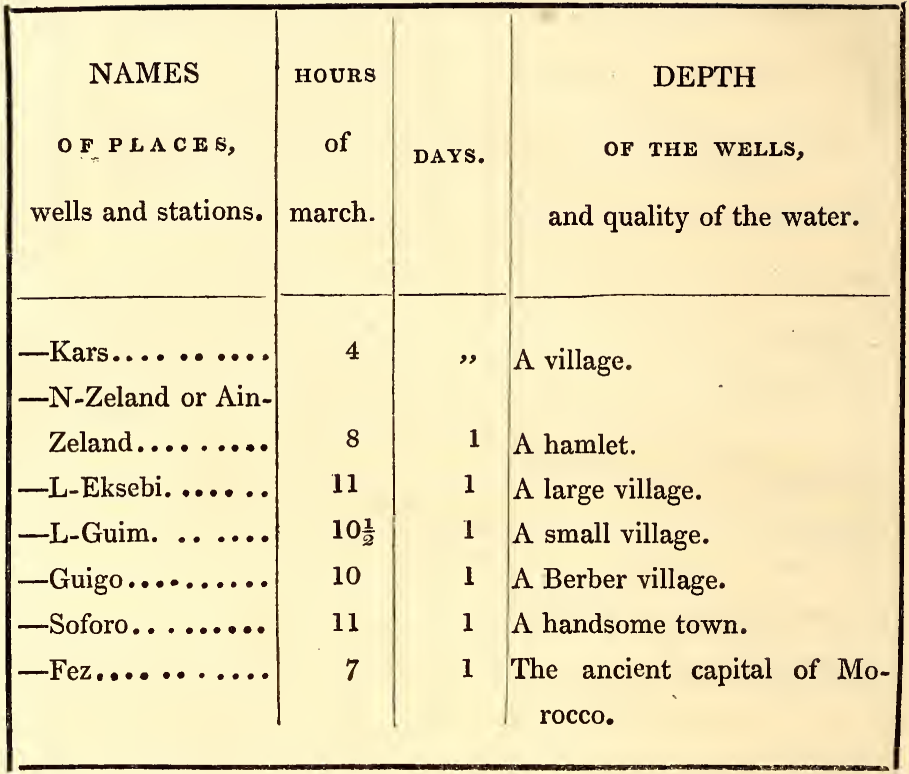




\section{A RT ICLE III.}

REMARKS ON THE GENERAL MAP OF THE TRAVELS AND THE ELEMENTS WHICH SERVE FOR ITS BASIS.

Having completed the construction of the itinerary, it remained to subject all these lines of route to the invariable data of which geography is already possessed. I first sought among these data for points common to M. Caillié's march : they are unfortunately very few in number. How then could I flatter myself, whatever trouble I might take, with whatever care I might combine all the data, hazarding nothing without some authority to support it, that I should produce any thing beyond a mere essay? If it should be hereafter confirmed by the observations of travellers furnished with astronomical instruments, the only merits of this work will consist in fortunate combinations; if it should be falsified by future discoveries, still it will have called for the criticism of geographers, and will consequently not have been useless to science. In submitting to the reader results differing from those hitherto admitted, I wish to warn him against an error, too common, especially in map-making, that of giving the preference to the more recent publications, and to place confidence in them in proportion as they are so. I am far from desirous of usurping this species of interest, to the prejudice of geographical works in general estimation. 
The points common to the route of M. Caillié and to the list of positions considered by geographers as perfectly or sufficiently established, are confined to the following : the points of the western coast of Africa, Kakondy, Timbo, Sami and Yamina (for the latitude), Bakel, Elimané, $\mathrm{Fez}$; and I shall add to them the position of Ain-Salah, though published here for the first time. With respect to the positions of Djenné, Timbuctoo, and the places situated in the great desert, the uncertainty is so great, that there is no resting any solid calculation upon them, and they are of no use in verifying the exactness of new itineraries.

Thus we are reduced, for a space which comprehends twenty five degrees of latitude and from ten to twelve degrees of longitude, to eight points in the interior.* Still, the point whence the traveller set out on the first part of his travels, the position of Timbo in the middle of this part, and the very prohable knowledge of the parallel of Sego, a town which is connected with the itinerary and attaches itself to the fixed points of the Senegambia, with the almost certain situation of Fez, form a first basis, which may serve to verify as well the inflections of the route as the length of the lines travelled over. I began by establishing the lines from Kakondy to Timé, from Timé to Djenné and Timbuctoo, and from Timbuctoo to el-Araouan; first, by supporting them separately upon Timbo, the parallel of Sego, and the position of $\mathrm{Fez}$; and

* I am not speaking of points more or less in the neighbourhood of the route, as Labé, or of the first part of the course of the Dhioliba. 
seconly, by attending to the declination of the compass. These lines were at first formed without any other modification than the necessary substitution of the true north for the magnetic north, in the night journeys. The direction of the first line from $\mathrm{Fez}$ gave me a very fair position for Timbuctoo ; and that of the second line from Timé furnished me with another but, little different, and which the situation of the parallel of Sego brought considerably nearer to the first: whatever uncertainty still remained has been cleared up by new data, of which it would have been difficult not to have made some use.

Whilst at Timé, the idea struck M. Caillié of observing the length of the shadow of a style at midday; his long stay there gave him an opportunity of making the observation twice : the first time, which was on the 3oth of October 182\%, the height of the style, with every reduction, was 0,706 metre; that of the meridian shadow was equal to 0,2945 metre.* The second observation was made on the 1st of November 1837; but this measurement cannot have been taken with so much precision. It was the shadow, properly speaking, which was

* The lengths of the style and of the shadow were taken with cords, which have been brought back to France, and which I have measured with the utmost possible care, comparing them with a good copper metre.

The style was a very straight stick, placed quite vertically, by means of a plummet, which the traveller brought away with him, and which is deposited at the vice-consulate at Tangier, in the hands of M. Delaporte. 
measured, that is to say, the shadow terminating distinctly and without the penumbra. The calculation gives for the latitude as nearly as possible nine degrees.*

This being admitted, I perceived that the construction (made in the manner before explained) of the line which represents the first part of the journey, gave to the situation of Timé the same latitude within a few minutes. This agreement convinced me that no change was required in the construction; so small a difference, considering the insufficiency of the means employed, might indeed be regarded as an entire concordance, and I could not but suppose that it was probably the effect of a fortunate compensation for many errors on the contrary side. I might therefore look upon Timé as a point nearly fixed, and leave it to establish the other two lines. The longitude of Timé, resulting from the preceding operations, is nine degrees two minutes west of Paris. Thus Timé would be at a nearly equal distance from the equator and from the meridian of Paris.

* I am indebted for this calculation, and for the following obliging notice to Lieut. Col. Corabœuf, of the corps of royal geographical engineers.

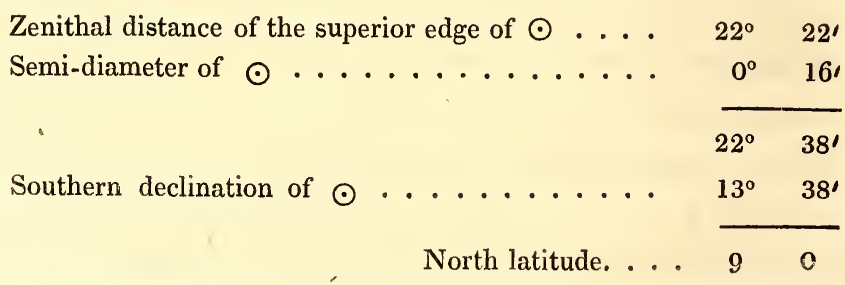


The bearing of the line from Kakondy to Timé, according to the travels of M. Caillié, having been confirmed, has given me confidence in the bearings of the rest of the route. I have therefore first laid down the line from Timé to Timbuctoo, and that from Timbuctoo to Fez, such as they result from the construction of the map of the route. The point of $\mathrm{Fez}$ being fixed, it became necessary to modify a little the absolute length and the direction of these lines, to confine myself between the two points of Timé and Fez, and I have proceeded upon a proportionate reduction. The difference was nothing extraordinary for so long a route, amongst so many obstacles and difficulties which the indefatigable traveller had to overcome. It amounted on the whole, upon near three thousand English miles,* to about one hundred and fifty, or a twentieth part of the space travelled over, and the total angular difference is less than six degrees upon the angle between the meridian of Kakondy and the direction upon Arbate. The latitude of Timbuctoo, obtained by this means, is near seventeen degrees fifty minutes north.

Possessing upon this latitude no geographical data properly so called, having only the routes of caravans, and not even the hours of march, but merely the reckoning of the day's journey, so that to the uncertainty of the length of the journeys is added the still greater uncertainty of the pace of the caravans, according to whether they were more or less numerous, whether composed of camels more

* Two thousand, eight hundred and forty nine miles and a quarter. 
or less laden, or only of pedestrians ; together with our ignorance as to the number and situation of the forced halts which they make in the desert, either on account of wells, or of those unforeseen accidents which will happen in these terrible peregrinations ;* in the midst, I say, of so many causes of hesitation, which ought to warn geographers against the employment of the vague itineraries of the Arabs and the Moors, could I grant less confidence to the route of M. Caillié than to the marches of the Africans?

These routes are constantly divided by hours: the rests are noted with exactness, and they are never undecided with respect to the length of the marches : it only remains then to estimate the pace, and we are enlightened on this latter subject by the composition of the caravan. For these reasons, and others still which it would occupy too much time to explain; I have not thought it right to take preceding itineraries into account in combining the elementary facts necessary for ascertaining the position of Timbuctoo.

I should, however, have still remained in doubt, and have abstained from offering an opinion had there not been other new data susceptible of comparison with the itinerary of M. Caillié; I mean the measure of the meridian

* I say nothing of the false information, which the natives, and especially the Moors, have wilfully given to Europeans, to keep them away from the centre of Africa; some out of fanaticism, others for fear of losing the advantages of commerce. 
shadow which he took at Timbuctoo itself. This observation was made by the same method as that at Timé : this proceeding is undoubtedly very imperfect, but, for want of others I think it should not be entirely neglected. On the 1st of May 1828 our traveller planted a style of the height of 0,635 metre; he measured, at noon, the shadow of this style and found it equal to 0,030 metre.* The calculation gives seventeen degrees fifty one minutes north latitude. I must repeat here the reflection that this agreement may very probably result from contrary errors which have balanced each other : but as it is impossible to discover the points in which the errors lie, or the limit of their extent, the final result is all that can be obtained.

I will add one consideration which will not have escaped those geographers who have studied the calculation of probabilities. In a series of observations made under the same circumstances, and especially by the same observers, the greater the number, the more probable is it that their amount will approach to the total quantity required. When there is no reason that the errors commit-

* Zenithal distance from the superior edge of $\odot \ldots \ldots 2^{\circ} \quad 26^{\prime}$ Semidiameter of $\odot \ldots \ldots \ldots \ldots \ldots$. 16 ,

242

Northern declination of $\odot \ldots \ldots \ldots \ldots 15 \quad 9^{\prime}$

North latitude 1751

I must not conceal the fact that M. Caillié made four similar observations in different places, which are too inconsistent with the itinerary to be made any use of. 
ted should be on one side rather than another, they mutually destroy each other, and the more so, the more the observations are multiplied. There is even a rule which teaches us how much the sum found differs from the truth; its discovery belongs to the learned geometrician, who is at present the organ of the French Institute for mathematical science. Knowing the error which may have occurred in an observation, it must be multiplied by the square root of the total number of observations. Thus, instead of growing with this number the total possible error decreases proportionably. For example, for four observations it would be represented by two, and for a hundred observations, by ten only. The proportion of total errors is therefore as $\frac{1}{2}$ whereas the proportion of the number of observations is as ${ }^{2} \frac{0}{4}^{0}$ : thus the error is but the fifth part of what it would be proportionally in four observations.* Hence it follows that the more observations are multiplied the more any imperfection in the processes by which they have been made will be corrected.

Are we not authorised to apply this principle to the length of M. Caillié's stages, since the number of the lines of route is not less than six hundred and thirty three?

* I have formerly given a rather remarkable example of an analogous application, in the height of the great pyramid of Memphis, measured by the assistance of mathematical instruments, and afterwards by the addition of the partial measures of the degrees, worked by imperfect processes. The results differ very little, but the number of the partial measures was 203 . 
I may add that the same remark applies to the angular deviation. Indeed, considering the total distance between the meridian of Timé and that of $\mathrm{Fez}$, or the difference in longitude (which is equal to one degree forty four minutes) as being the real sum of all the angles of the route to the east or west of the first, it will follow that the forming of the lines of bearings noted by the traveller (or the calculation of the angles, which is more exact) gives a total variation, so much nearer to the above difference of longitude as the number of bearings is greater; and this number is also six hundred and thirty three. As it has been seen above, I have found the deviation equal to less than six degrees, and it has been easy to divide it over the whole line. 


\section{OBSERVATIONS ON THE SITUATION OF TIMBUCTOO, AND PARTICULARLY ON ITS LONGITUDE.}

From the determination of the lines which join Timé Djenné, Timbuctoo, and Fez, and from the latitude of Timbuctoo thus fixed according to the itinerary at seventeen degrees fifty or fifty one minutes, * necessarily results a more westerly longitude of this city, than has been hitherto supposed, and even than that which I had formerly admitted, and which brings its position much nearer to the ocean than any geographer has placed it.

Such is the importance of the situation of Timbuctoo that I deem it necessary to insist again on the discussion of the elements; in order, not to establish it with certainty (I am far from believing that I have accomplished this) but to furnish the reader with new means of approaching the truth, as nearly as the state of our knowledge will permit. It is true that a single astronomical observation made by a skilful observer, furnished with good instruments, and worthy of confidence, might overthrow these inductions ; but it is equally true that till we are possessed of such an observation, no geographer can fix this main position on a map, without deducing all the reasons which

* The latitude as determined by M. Walckenaer approaches very near to this result. 
determine him, especially if he dissents from the opinions of his predecessors.

Timbuctoo is placed, on the general map of the travels, in the latitude resulting from the observation of the shadow and the length of the route from Timé to Timbuctoo. A great part of this route, it may be observed, is in a northerly direction, which was far from being conjectured from the course of the river in this quarter. If Mungo Park could have acquainted us with the particulars of his journey beyond Sansanding, we should not have been so long uncertain of this direction, which has uniformly been carried easterly, and that because the situation of Timbuctoo was imagined (as it is still) to be very central in the continent. Park's map (travels in 1805) places it under the meridian of Paris; Clapperton at $0^{\circ} 5^{\circ}$ ' west. Rennell at $2^{\circ} 3^{\circ}$ ' : but the data of which we have been for ten years in possession oblige us to bring it nearer to the ocean; M. Walckenaer has done so, in adopting a longitude from nine to twelve minutes more westerly. I have always proposed to carry this position much farther west, and even placed it four years ago four degrees west.* M. Brué has since adopted $3^{\circ} 34^{\prime}$ : perhaps it should have been advanced as far as the sixth degree. For the reasons I have elsewhere given, the route from Timbuctoo to Fez cannot be fixed at more than two English miles an hour: to this rate I have reduced the

* See the Bulletin of the Geographical Society, the second volume of its memoirs, and the map of the course of the Gambia beyond Coussaye etc. 
computation of $\mathbf{M}$. Caillié, who at first estimated the whole route equally at three miles. Now the line of route thus constructed and resting upon Arbate, a well known position, carries Timbuctoo very near the eighteenth degree north; that is to say, from $17^{\circ} 50^{\prime}$ to $17^{\circ} 55^{\prime}$; had not this been shortened a little, the city would have been carried to $19^{\circ}$, or $20^{\circ}$, a position far too northerly, and totally inadmissible. Moreover, the line from Timbuctoo to Arbate would be ten degrees too far west; it would also be increasing the declination to $27^{\circ}$ instead of $17^{\circ}$, which seems to be its amount for the mean meridian.

But, if the bearing of the line from Timbuctoo to $\mathrm{Fez}$ resulting from the itinerary, and that of the line from Timé to Timbuctoo, are preserved, these two intersect each other about the parallel of $17^{\circ} 50^{\prime}$. This latitude agrees so well with that resulting from the height of the shadow, $17^{\circ} 51^{\prime}$ that we derive from these data a very satisfactory confirmation. Now the line of the parallel $17^{\circ} 51^{\prime}$ and the two lines of direction meet, all three, on nearly the same meridian, the sixth west from Paris.

No positive data are yet known which can better fix the longitude: not only are the itineraries of the Moors too vague, but they support themselves upon the Mediterranean, while M. Caillié's routes, though they are continued to the Mediterranean, support themselves upon the ocean; which is much nearer than the former, and also upon the known positions of Timbo and Fez. 
Suppose, however, it were determined, notwithstanding all these reasons to withdraw 'Timbuctoo farther to the east by a degree or more, it would then become necessary greatly to increase the journeys from Kakondy to Timé. In making them three English miles and three fifths an hour, the true measure has probably been somewhat exceeded, but the situation of Timbo compelled this; while, to place Timbuctoo on the third degree of west longitude, would be to suppose a march of more than four miles and a half an hour.

Another circumstance here comes to our assistance: it is that by carrying it farther towards the east, we must suppose the traveller greatly and constantly deceived in a western direction on his journey from Timé to Timbuctoo, and, on the contrary, in going from Timbuctoo to $\mathrm{Fez}$, he must have made a similar and not less considederable error in all his bearings towards the east. How should we account for this singularity ?

From all these considerations, could I risk changing the result of M. Caillié's itinerary and altering the construction of his route? could I, in short, without sufficient motive, give the preference to any one map over another ? Some judgment may be formed upon this question from the diversity of situations assigned to Timbuctoo by different authorities : 
In 1720 , the longitude according to Delile. $0^{\circ} 0^{\prime}$ W. of Paris. 1749, d'Anville. . . . . . 2. 15 . 1790, Major Rennell. . . . . . 2. 30. 1796, Park's first map. . . . . . . 1. 0. 1805, Park's second map. . . . . . 0. 0 . 1821, M. Walckenaer . . . . . . 2. 42. 1821, M. Lapie. . . . . . . . 2. 44. 1822, Clapperton. . . . . . . 0. 50. 1828, M. Brué. . . . . . . . 3. 34.

It is on the English maps, even those of most recent date, that this town has always been placed the most to the east. The advantage of a more eastern position relatively to the proximity of a great river flowing into the Gulf of Guinea would be evident: but this proximity is nothing less than certain. By a coincidence worthy of notice the English maps have also brought Timbuctoo farther to the south than any others except Delile, as will appear from this table of different latitudes :

\section{North latitude according to}

Delile. . . . . . 15 15. 01. Park's second map. . 16 ${ }^{\circ}$. $27^{\prime}$. Clapperton. . . . 15. 0.

M. Brué (after ClapperM. Walckenaer. . . . 17. 38. M. Lapie. . . . . . 17. 38. ton). . . . . . 15. 0. Park's first map. ... 15. 14. Major Rennel. ... . 19. 38.

I return to the latitude of Timbuctoo. Ain-Salah, in the oasis of Touat, is usually placed about $1^{\circ}$ east of Paris and in $24^{\circ} 30^{\prime}$ north latitude ; but Major Laing's 
observation, as communicated to me by Captain Sabine, is very different, namely : $0^{\circ} 29^{\prime}$ west of Paris, and $27^{\circ}$ $11^{\prime} 30^{\prime \prime}$. M. Walckenaer has calculated the distance from this oasis to Timbuctoo at six hundred and seventy five geographical miles : it is evident that this measure, if admitted, would advance Timbuctoo towards the north to between the 17th and 18th degree; now, it happens that this distance of six hundred and seventy five miles is found exactly between the two points as placed upon the present map. This last coincidence, which I remarked after my labour was concluded, contributed still farther to dispel my doubts. I have estimated the day's journeys at $18^{\prime}$ four tenths and not with $\mathbf{M}$. Walckenaer at $15^{\prime}$; but it was the medium journeys, not those of the great caravan, which formed the object of his researches. It appears then that the approximative situation assigned to Timbuctoo, $6^{\circ}$ west and $17^{\circ} 50^{\prime}$ north, satisfies the different data, and the best itine. raries, that it agrees with the positions of Timbo and of Fez, and that it is not contradicted by Mungo Park's observations on the latitude, taken at Sami and Yamina; finally, it is confirmed by the particulars brought from Elimané by Captain Beaufort.

Fifty four days' journeys will be found on my map from Timbuctoo to Tatta; an itinerary cited by $\mathbf{M}$. Walckenaer (p. 297) marks fifty. The fifty four days from Fez to Timbuctoo according to Mr. Jackson* also 
agree; it is the same with the sixty-four days from Timbuctoo to Morzouk. Fewer than twenty eight journeys are reckoned from Houssa to Timbuctoo, according to the itinerary of Mohammed Ebn-Foul; this distance is too short on our map, and on all the others, even those in Clapperton's travels. There are, besides, other reasons for believing that there may be two towns or countries called Houssa*.

I do not compare with the map the distance reckoned between Timbuctoo and the town of Tafilet, because M. Caillié heard no mention of a town so called : he affirms that none such exists, in which case it is not possible to make use of this distance.

I shall add in conclusion of this discussion, that nothing can authorise us to depart from the observations of latitude taken by Mungo Park, at Yamina and Sami, namely, $13^{\circ} 15^{\prime}$ and $13^{\circ} 17^{\prime}$, and to remove these points much further to the south, as M. Brué has done upon his map, otherwise so rich in details and nomenclature. The determination which I propose for the latitude of Timbuctoo agrees better with these observations, the only ones we possess in this direction as far as Timbuctoo.

* In his letter dated from Timbuctoo, Major Laing speaks of a distance of fifteen days' journeys between Sego and Timbuctoo; I find upon the map about three hundred and fifty-four miles in a direct line; the days' journeys are of twenty four miles, or those of a light caravan. 
From the whole discussion, it results, first, that the different lines of route forming the itinerary map have been subjected to divers conditions resulting from the journal of the traveller, from anterior observations and from good geographical data; secondly, that the hour's journeys, estimated at three English miles, mean measure, between Kakondy and Galia or Djenné, are a little increased between Kakondy and Timé, in consequence of the position of Timbo; thirdly, that, from Djenné to Timbuctoo and thence to Fez, the average of two miles an hour has been a little modified by the real difference in latitude of the two extremities. I have now only to speak of the bearings and measure of the lines of march. 
BEARINGS OF M. CAILLIÉ'S ROUTES.

The reduction of the true north of our traveller's lines of route was one of the most important points ; and to arrive at their actual bearing, I was assisted by a single new datum only; namely, the observation of the angle of the meridian shadow with the magnetic north. The travels furnish two of these observations : the one, of the 30th of October 182\%, gave the N. N. E. ; the other of the Ist of November, the N. $\frac{1}{4}$ N. E., that is to say, the compass had on these days a declination of $22^{\circ} 30^{\prime}$ and $11^{\circ} 15^{\prime}$ to the east. I was then obliged to have recourse to other researches to determine between these two measures, and to avail myself of several observations taken by Mungo Park and other travellers.

The following are the names of the places and observations; I omit their geographical situations :

At Badoo, Mungo Park.*. .......14 ${ }^{0}$ 6' E. declin.

On the Bâfing, idem............16 30

On the Dhioliba, $i d e m . \ldots \ldots \ldots \ldots \ldots 16 \quad 36$

At Yamina, idem............17 11

At Sansanding, idem............17 40

At Bathurst, Captain Owen.†......17 56

* The Journal of a Mission to the Interior of Africa, \&c. p. 164. $+A$ Chart of the River Gambia, \&c. 


\section{IN CENTRAL AFRICA.}

At St. Louis, Maritime Annals*......17\% 32 E. declin.

At St. Mary, M. le Prédour.†.......17 25

At Cape Roxo, idem.............17 20

In Mungo Park's journal of his second expedition, as printed in London, is a tracing of the Gambia, $\ddagger$ from which a smaller declination would result: it appears evident to me, that some error has crept in here, either in the copying or in the engraving, when the coincidence of the preceding observations from five different travellers is considered, and particularly that of Park's own observations.§ To these might be added the declination observed by Major Laing in his first journey, and that which has been observed at Sierra-Leone and other places; but this inquiry would be superfluous. It will be remarked, that the mean term of $16^{\circ} 55^{\prime}$ declination east, is also the mean between the two observations of M. Caillié ; but, as the observation of Badoo seems rather small compared with all the others, I have thought myself entitled to adopt $17^{\circ}$ as the mean declination and to subject the whole route to it.

* Annales Maritimes for the year 1827, second part, vol. ii, p. 276 .

$\uparrow$ Ann. Marit. for the year 1828; second part, vol. i, pages 933 and $94 \mathrm{l}$.

$\ddagger$ The Journal, \&c. p. 21.

§ M. de Beaufort has made, at Senegal, two observations which differ from the above by more than $5^{\circ}$, and others which exceed from 2 to 5 degrees: this variation is, no doubt, owing to local circumstances. 
I shall here make another remark respecting the situation of places marked upon the two maps, upon information communicated by others, and not direct observations; it is that the natives are extremely clever at indicating the direction of places at a greater or less distance: they are seldom mistaken in this indication; and they point out with the finger with great accuracy, the direction which must be taken to go in a straight line to a given spot. This observation has been made before. When a certain direction was thus pointed out to $\mathbf{M}$. Caillié, he remarked some particular object on the line, and applied his compass to it at the first favourable opportunity. These bearings have been extremely useful to me for the points situated beyond the route; without this assistance I should have found it impossible to trace, even tolerably, the course of the Dhioliba above Djenné. 
COMPUTATION OF' THE DAYS' JOURNEYS:

The geography of countries which have not been explored by observers furnished with instruments is usually reduced to the calculations of days' journeys. What can be more vague or doubtful than such documents? The most learned discussion (as remarked above), can only elicit feeble scintillations from them. How are contradictory accounts to be reconciled? How are common days' journeys to be distinguished from double days, or even longer still? It is evident, that itineraries must be examined and compiled from the number of the hours jour-. neys, and not by the days, and there would then be a less degree of uncertainty. Should European travellers themselves compute their lines of march by the days' journeys? And how happens it that it is not an established rule, in exploring distant and unknown countries, to keep an exact account of the hours and every fraction of time? The journal of M. Caillié, although he has not rigorously complied with this condition, at least presents an uninterrupted continuity of marches measured by time, generally by hours, sometimes by half-hours and even quarters. But for this persevering (and amidst so many fatigues truly laudable) attention, positive geography would have gained very little by these long and toilsome peregrinations. 
In a memoir inserted in the eighty-first volume of the Philosophical Transactions, Major Rennell has fixed the day's journey of a caravan heavily laden at sixteen geographical miles (or minutes of a degree) and one sixth; and that of a light caravan, at seventeen miles and one third. It appears to me, that the second of these results is too small, and especially that an intermediate term should have been established, between the light and the heavy caravans, for there is a vast difference between the two extremes. The former certainly advance more than twenty geographical miles a day, especially, as they are able to continue their journey longer, that is to say, for a greater number of hours each day. Then, again, it would be convenient to fix an intermediate valuation between sixteen and twenty miles, that is to say, the day's journey of the medium caravans, if they may be so called. I find Major Rennell's appreciation of the first denomination of days' journeys confirmed by the experience of the engineers attached to the French expedition, in crossing the deserts near Egypt. We estimated the hour's march at nineteen hundred toises; eight hours would amount to fifteen miles two hundred toises, or very nearly sixteen geographical miles ; the hour's march would thus be established at two miles, or thirty hours to the degree. In consequence of several calculations much too long to be reported here, I consider the day's journey of the medium caravan to be eighteen geographical miles and four tenths, the hour being between two miles and two miles and one tenth. I shall not here take the light caravans into ac- 
count; these travel longer, and the progress of each hour is at the same time greater ; but $I$ think it may in many cases be estimated at twenty-two miles, or ten hours of two miles and two tenths. Persons travelling in small parties, without reckoning men mounted on horses or dromedaries, move still quicker.

According to Captain Lyon, the days' journeys of the caravans are less than twenty English miles, and above seventeen; that is to say, more than the short day, and less than the medium. It is not by the pace either of a pedestrian or of a lightly loaded camel that the progress of a caravan must be measured, but, on the contrary, by that of the man or camel bearing the heaviest burden; for the latter must be waited for by the former, and is perpetually retarding the march; otherwise the usual pace would be much greater than that just fixed. Besides, this reduction of the average value is independent of that which must be allowed for the deviations and turnings which are often unknown: another source of hesitation and of error to geographers.

The earlier journeys of M. Caillie on leaving Kakondy afford an example of the real amount of the day's journey: the first day, he advanced twenty-three English miles, the following sixteen miles and a half; the third eighteen miles; the average rate nineteen miles and one sixth.* The hour's journey was estimated by him at

* The journeys of the subsequent days were shorter. 
three miles only, but the construction of the itinerary proves that this computation was more than one tenth too small. The result is twenty one English miles,* which is very near eighteen geographical miles and four tenths; all, by my estimation, medium days, (or days of a medium caravan). Indeed, the small caravan to which M. Caillié then belonged may be balanced against these considerations-first, that though small in number it included a woman; secondly, that all were on foot; thirdly, that all were loaded. In traversing the desert, the day's journeys were of twelve hours and sometimes more ; $\uparrow$ but exhaustion, thirst, and fatigue, prevented both the travellers and camels from keeping up the same pace as on their first departure, and a mile and a half an hour is a large allowance for the march.

I ought here to report the opinion of M. Walckenaer, who has discussed with much sagacity this important geographical question : $\ddagger$ he fixes at fifteen minutes the amount of a day's journey of a caravan heavily loaded; this amount falls short by only one sixth of that which I have adopted, from our own experience in Egypt, and which further confirms the opinion of Major Rennell.

* It is the same with the route from Timbuctoo to Arbate.

+ Impatience to arrive, and above all, the imperious necessity of reaching the wells, sufficiently account for these long journeys through the desert.

$\ddagger$ Recherches sur l'Afrique septentrionale, \&c., page 266 . 
But M. Walckenaer does not estimate the other two denominations of days' journeys, those of the medium and of the light caravans. I shall only remark that the result of his arguments seems to be, that the real and effective progress is considerably more than $15^{\prime}$, and about equal to 18' or 19': the average of a day's journey reduced to measures taken in a straight line upon the map. But will the diversity of elbows and inflexions, resulting from that of the obstacles which produce them, allow us to work a uniform reduction, and to apply a uniform factor to every distance travelled over ? Let us, for instance admit that part of the route amounts to sixty miles, and that the straight line between these extremities is fortyeight miles; can the same rule be adopted with regard to the whole route, which may be three hundred miles or five times as much? would the total direct line amount to two hundred and forty miles? The longer the route, the greater should be the variation in the rate of the reduction. The following table contains a summary of these observations upon the amount of the hours' and days' marches of caravans, and the different computations which have been made of them. 


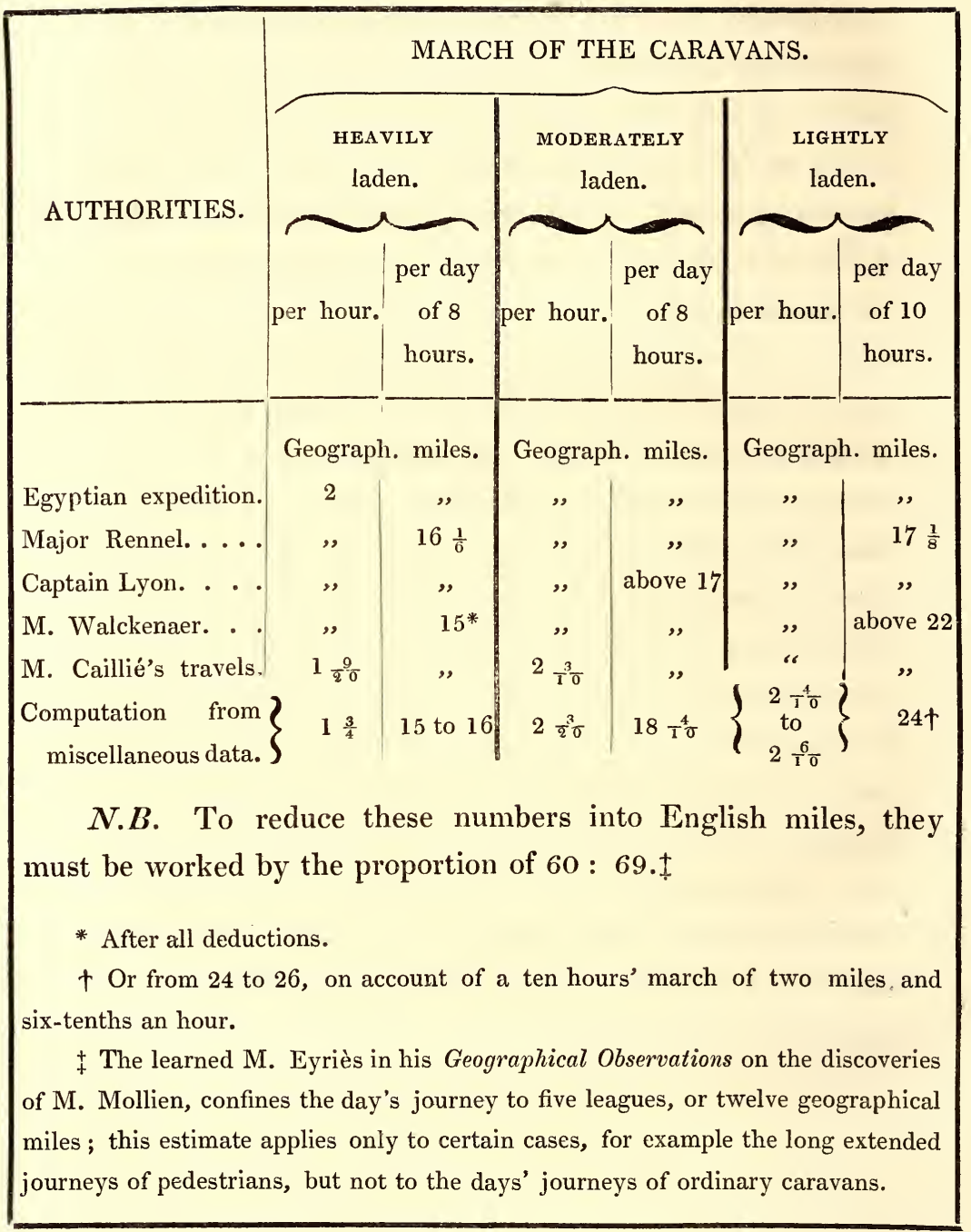

I had at first intended to construct separately each of M. Caillié's routes, taking into consideration in each particular case the difficulties of the ground, the compo- 
sition of the caravans, and the physical condition of the travellers; but, as it was impossible to perform this work correctly, it would also have been useless. Besides, the reflections which I have already made tend to shew that, by following a uniform plan of reduction from one end of the route to the other, one must arrive at a result nearly approaching to the truth.

All that I have hitherto advanced relates solely to that part of the general map, which represents the space travelled over by M. Caillié; I have now to speak of the remainder, namely, the extremity of the map towards the north, and that towards the S.W. The former portion, or the country of Morocco, has been chiefly extracted from the fine map of M. Brué,* but reduced to much fewer details; we know that he sought his data in the best Spanish and English maps, and in the works of Badia, Jackson, Walckenaer, Ritter, \&c.; authorities which furnish excellent materials, but which, the former especially, must not always be employed without the assistance of criticism.

The second part, to the south of the Rio-Nuñez, has been drawn from the Senegambie of M. Dufour, who has skilfully combined the materials of Major Laing with those of preceding English travellers : it will be seen by comparing our two maps, that I have been obliged to differ from him with respect to the situations and names of several countries. I have also been necessitated, as well for

* Carte générale des Etats du Nord de l'Afrique, \&c. 
the sake of perspicuity on a map upon a very small scale, as on account of uncertainty, to retrench many details. I shall conclude with the table of geographical positions, forming the foundation of the general map, independently of the coast of Africa, which is pretty accurately known.*

* The data and calculations exhibited above, being the basis upon which I have reduced the itinerary map and used it for the general map, it is superfluous here to explain more at length the necessary differences between the two; but I have considered it equally my duty to give the first without modification, that is to say constructed solely upon the estimate of the journeys. I shall here give the general result of M. Caillié's days' journeys, which, as a whole, deserve attention for their continuity and extent.

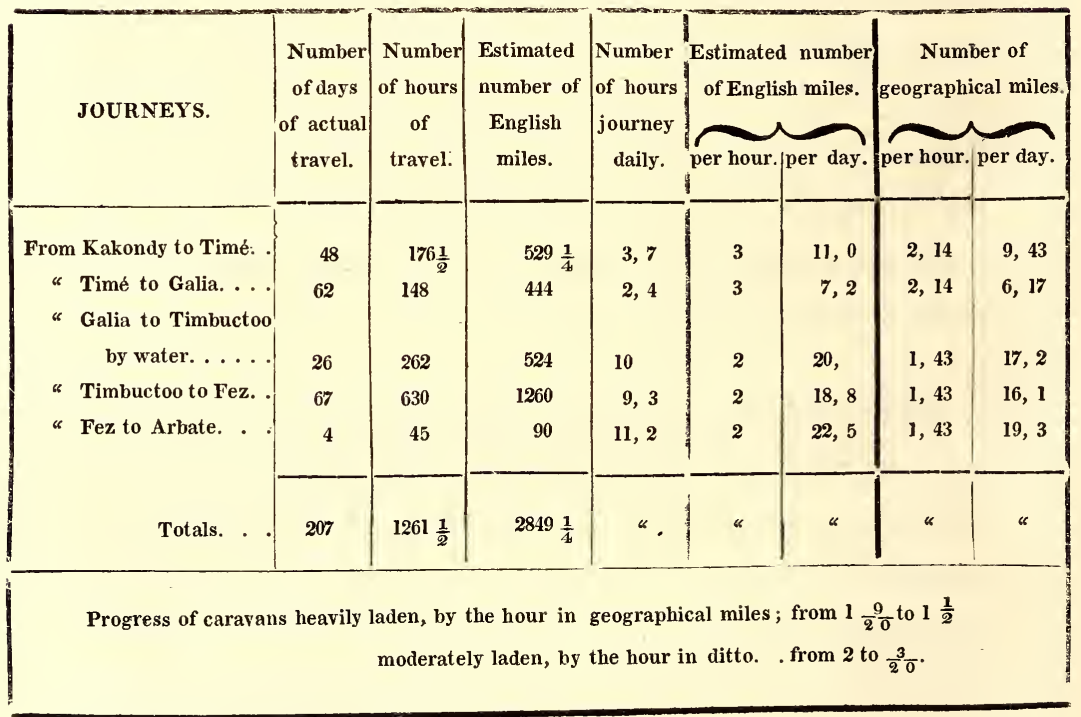




\begin{tabular}{|c|c|c|c|}
\hline & N. Latitude. & $\begin{array}{l}\text { Longitude W. } \\
\text { from Paris. }\end{array}$ & AUTHORITIES. \\
\hline 'Timé. · · · & $\begin{array}{lll}9^{\circ} & 3^{\prime} & 0^{\prime \prime}\end{array}$ & $\begin{array}{llll}9^{\circ} & 2^{\prime} & 0^{\prime \prime}\end{array}$ & $\left\{\begin{array}{l}\text { Construction of the } \\
\text { map. }\end{array}\right.$ \\
\hline $\begin{array}{l}\text { Dhioliba at } \\
\text { Mount Loma. . }\end{array}$ & $\begin{array}{lll}9 & 25 & 0\end{array}$ & $\begin{array}{lll}12 & 5 & 0\end{array}$ & Major Laing. \\
\hline Timbo. . . & $1025 \quad 0$ & $1254 \quad 0$ & $\begin{array}{l}\text { Major Laing. } \\
\text { Construction of the } \\
\text { map. }\end{array}$ \\
\hline Kakondy. . & $\begin{array}{lll}11 & 10 & 0\end{array}$ & $\begin{array}{lll}16 & 17 & 0\end{array}$ & $\begin{array}{l}\text { M. Brué's map, } \\
\text { long. } 16^{\circ} 24^{\prime} .\end{array}$ \\
\hline Djenné. . . & $\begin{array}{lll}13 & 0 & 0\end{array}$ & $\begin{array}{lll}9 & 0 & 0\end{array}$ & Park. \\
\hline Yamina. . & $\begin{array}{lll}13 & 15 & 0\end{array}$ & " " " & Idem. \\
\hline Sami. . . & $\begin{array}{lll}13 & 17 & 0\end{array}$ & " " " & Idem. \\
\hline Bakel. . . & $\begin{array}{lll}14 & 13 & 30\end{array}$ & 144140 & Dussault. \\
\hline Elimané. . . & $15 \quad 2 \quad 50$ & $1236 \quad 0$ & De Beaufort. \\
\hline Timbuctoo. & $1750 \quad 0$ & $\begin{array}{lll}6 & 0 & 0\end{array}$ & $\left\{\begin{array}{c}\text { Construction of } \\
\text { map. }\end{array}\right.$ \\
\hline Ain-Salah. & $27 \quad 1130$ & $\begin{array}{lll}0 & 29 & 0\end{array}$ & Major Laing. \\
\hline Morocco. . & $\begin{array}{lll}31 & 37 & 30\end{array}$ & $956 \quad 0$ & Badia. \\
\hline Fez. & $\begin{array}{lll}34 & 6 & 0\end{array}$ & $\begin{array}{lll}7 & 18 & 0\end{array}$ & Idem. \\
\hline
\end{tabular}




\section{$\S$ III}

OF THE NOMENCLATURE.

I shall not here offer to the reader a general list of the names of towns and villages, or of the different nations, states and districts visited by M. Caillie during his travels; this duplicate labour is rendered quite unnecessary by the minute list of the Itinerary* contained in this volume, and by the journal itself, both of which I recommend it to the reader to consult upon this subject. My object is merely to make some remarks upon the method of retracing these names and upon a few other relative points. The nomenclature is so much the more important in the compilation of African maps, as inattentive travellers frequently confuse generic appellations with proper names and vice versa $\vec{a}$; or they spell the same name in several different ways, or in writing various names they lose sight of the trifling differences by which they are distinguished. Hence the faulty multiplication upon the maps of places which do not exist, and on the contrary the suppression of many which do. The difficulty is great, particularly with respect to countries recently explored and the language of which is unknown. I have chiefly confined myself to obtaining the names from the mouth of the

\footnotetext{
* See Chapter 3.
} 
traveller as his memory furnished them, and comparing them in his presence with his journal.

Among other generic terms which have been considered as proper names, I shall particularize two, on account of the confusion which they have introduced, and which involves in obscurity some important geographical questions, namely the situation of a considerable chain of mountains to the south of the 8th degree of latitude, and the still unknown outlet of the great central river. Kong, is the name given, particularly since Mungo Park, to a great chain of transverse mountains which he reports to have seen at a distance to his right, when travelling from the Gambia to the Dhioliba. Now, M. Caillié learnt from the natives that Kong is a generic word, and that in the Mandingo language it signifies a mountain; the mountain or chain of mountains in question is accordingly far from being the only one of its name. I remark also, that the English traveller in his Mandingo vocabulary explains the word Kong by head; whence perhaps the signification of Kong; and himself translates Konko by hill.*

When the later English travellers had gained intelligence of a river called Couara, to the west of Saccatou, and of the river which is near Funda, it was remembered that this name is also borne by the upper Dhioliba, and these three rivers have been at once identified; but it appears that Couara is a general term signifying a river. 'The 
inhabitants who in three different places have been asked the name of the river, not understanding the question, have answered by the word river. Already had this confusion taken place a hundred times with the words $b a, b a h r$, and nil, which also mean river, running water, great water. There is on the road from Timé to Djenné a village named Couara, and near it a river of moderate breadth, called Coraba (or according to my idea Couara-ba,*.) It is easy to perceive from the face of the country, that it is a tributary of the Dhioliba, which was also reported to $\mathbf{M}$. Caillié; here then is another river of the same name, or rather another general denomination which confirms the import of the word Couara, already observed by travellers.

I have noticed that the Arabic, kha $\dot{\varepsilon}$ ' is used every where, even in the countries where the Arabic language and Islamism do not prevail: the traveller had expressed it by a blank; I have written it $k \grave{h}$ according to the general custom. The slightly lisping sound $\dot{\varepsilon}$ is used in many central districts, as is a liquid sound, common also in Senegambia, and which may be written ghi or dhi. The name of the town of Jenné has been written Djenné, because the Arabs of the present day write $8 \dot{\text { ج }}$ or li but M. Caillié remarked that the natives pronounce $d h i \mathrm{I}$ am therefore inclined to prefer Dhienné.†

* Couaraba, or River-River; thus the Africans call the Nile $B a-b a$.

+ See below $\S \mathrm{V}$. 
M. Caillié knows nothing of the Island of Jinbala marked upon Park's map, but he was not wholly a stranger to the name; he mentions a tribe of Jinbalas to the north of Timbuctoo.

I entertain doubts, which time alone can remove; respecting the names of many places, and 1 have therefore thought it better to preserve those names without alteration. I have only omitted, upon consultation with the traveller, letters which appeared useless to the pronunciation, or which might create difficulties. The names of such places as Brahihima no doubt require rectification; the name of Abrahima, or Ibrahima, \&c., are met with in some travels.

I have suppressed the letter $q$ and almost always the $k$, except before $e$ or $i$, confining myself to the use of $c$. The double $s s$ merely expresses the sound of an initial $S$. The $w$ and $o o$ of the English, which M. Caillié acquired the habit of using at Sierra-Leone, I have expressed upon the maps by ou; the words in the text have been generally subjected to the same rules.

On the route to the Tafilet such names as Tamaroc and M-dayara, \&c., occur on account of the use of the initial letters ' $\mathrm{T}$ and $\mathbf{M}$ which announce the vicinity of the Berbers. The wells of Trasas or Trazah should perhaps be pronounced T-ghazah or T-ghazzah, which will correspond 
with the Tegasa or Tegazzah of Leo Africanus*. In several words beginning with $\boldsymbol{L}$ as L-Eksebi, L-Guedea, L-Eyarac, L-Guim, \&c., the Arabic article $a l$ appears to me to be joined to the name by contraction, as in the vulgar pronunciation throughout Northern Africa. The words beginning with the letter $n$ should perhaps be pronounced ain, which signifies a source or fountain. I hazard this conjecture from the presence of wells at such places, and from the example of Ain-Salah, in the oasis of Touat, which is frequently written Ensalah, or Nsalah, in a single word. It is difficult for Europeans to prorounce the guttural $\varepsilon$, and they frequently leave a blank for it, as well as for the $\exists$ and the $\dot{\mathcal{C}} \cdot \mathbf{I}$ presume, therefore that the names Nzeland, Nyela, \&c., stand for Ain-Zeland, Ain-Yela; but this supposition may perhaps be refuted by the ortho. graphy of the name of Hanalak or (Hen-Alak) هil a place situated upon the route from the country of Galam to Morocco.

I shall take this opportunity of giving the Arabian orthography of the names of several places belonging to the space between St. Louis, Timbuctoo, and Morocco ; I am

* "This place," says Leo, " is a very abundant mine of salt, whiter than marble, at the distance of about twenty days' journey from any inhabited spot, and having wells of very salt water only." The author does not give its exact situation. See Descrip. Africe, 1. 6, p. 425, Figur. 1559 . 
obliged for them, to the Baron Roger, formerly governor of the Senegal, and who has lately enhanced, by important publications, the title he had long since acquired to general esteem, by the improvements of all kinds which he introduced into that country. 
IIST OF THE NAMES OF SEVERAL PLACES IN NORTHERN AFRICA.

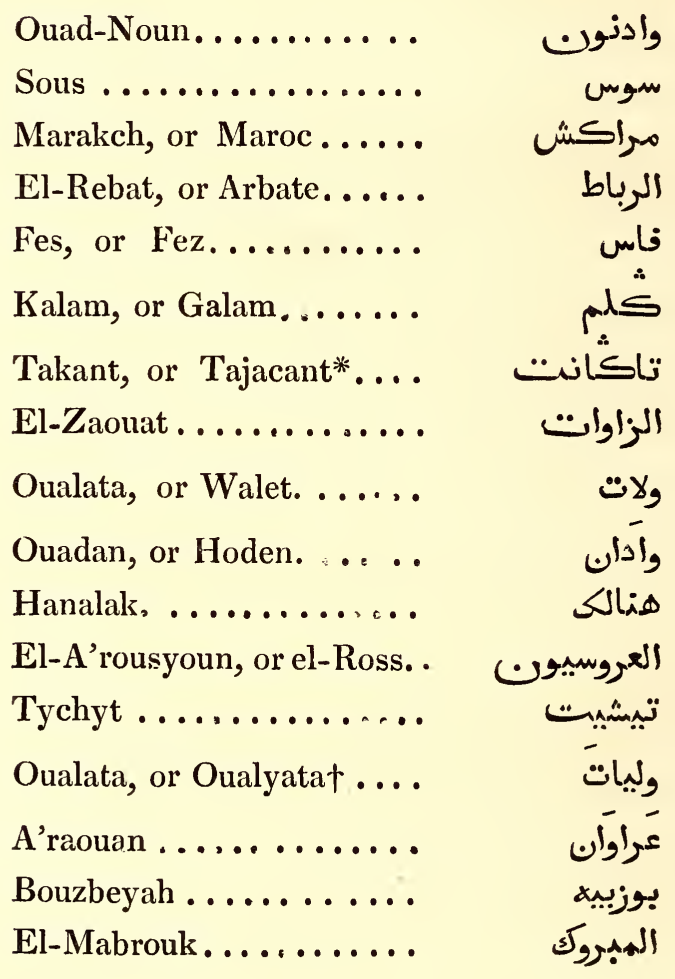

* I apprehend this word to be corrupted by the Europeans because Kount, the same perhaps as Kant, is actually the name of a tribe of the Sahara, according to M. Caillié's Itinerary.

$\uparrow$ Perhaps a different place from Walet, as I have conjectured above. 

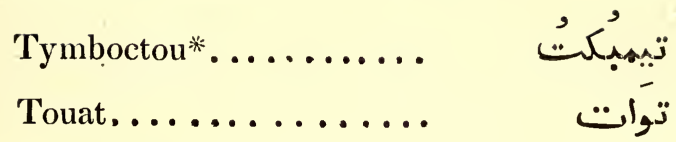

This list contains the names of several Moorish tribes and colonies of different nations, the orthography of which is uncertain. It would require very laborious research, and assistance which will be long unsupplied, to write these names more correctly : I have contented myself with discarding from the names occurring in the journal all useless letters, and those which do not accord with the sound as remembered by our traveller.

Science would be much benefited by the careful examination of the names engraved on the maps of Northern Africa, without excepting those recently published, and the indication of the duplicates and false names, which are real blemishes in works otherwise of great value; but this labour, even as regards the countries which belong to my subject, would occupy too much time. The nomenclature is of more importance than is usually ascribed to it by the

* When properly written, I do not think that this word contains a $\leqslant$ ye. We may be satisfied, however, with the orthography Temboctou, and the word is perhaps composed of the Berber particle $t e$ or $t a$, as Tamaroc, Takant, Tarekne, T-rarzas, T-razah, etc., and of m-boctou, formed like M-dayara. I know that Ben.

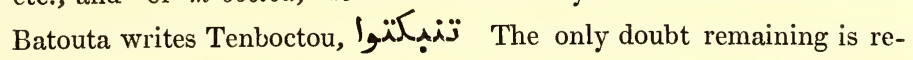
lative to the use of the $m$ or $n$. See The Travels of Ibn Batouta, English translation by Mr. Lee, London 1829, p. 237. 
compilers of maps; I consider it one of the fundamental principles of geography: there are maps which would merit the appellation of classical if they answered in this respect to their precision and merit in all others. Two things are wanting to enable us accurately to fix this nomenclature : the names written by a native, and the pronunciation collected with great attention*.

* See in $\S \mathrm{V}$ further on, several remarks upon the nomenclature. 


\section{$\S$ I V.}

OF SOME RESULTS OF THE TRAVELS OF M. CAILlí́.

Of all the results, for which we are indebted to the new travels, that which most excites curiosity is unquestionably the knowledge of the city of Timbuctoo; but, perhaps that which is most important to geography is the course of the great central river. Although M. Caillié was unable to give information of it beyond Timbuctoo, he has conferred a real service on science, since he describes its banks with circumstantial detail from Djenné to that city, and gives us an idea of its course above Djenné. By crossing it at Couroussa, and after advancing more than two hundred English miles farther east, then travelling as far as Djenné on the right bank, he has furnished reason for concluding that no river parallel with the Dhioliba exists there, as traced upon the maps. The river, on the contrary, receives in this quarter pretty numerous tributaries, which, from their importance, seem to denote a distant source.* We perceive from the description that both banks of the river, a little beyond Bamakou, are very open, and their declivity gentle, which explains the existence of vast accumulations of water, of which the Lake Debo or Dhiebou is the most considerable. Whatever opinion may

* On the left bank the Tankisso, and several others; on the right bank the Couaraba, the Bagoé, \&c. 
have been previously formed of the existence of a lake in this part of Africa, we were utterly ignorant of its situation, its true name, its form, and extent. The islets, on which our countryman has thought himself entitled to bestow names, will perhaps one day prove remarkable points. Their occupation would suffice to intercept the navigation upwards and downwards, and by thus rendering their possessor master of the river to influence the commerce of interior Africa; a commerce, comprehending on one hand, the gold extracted from the rich mines of Bouré, and the productions of Kankan, Ouassoulo, and FoutaDhialon, the merchandise of the Mandingoes, and all the articles of Djenné ; on the other, the productions which Timbuctoo receives from the northern coast, and every thing transported thither by the Moors from the north aud north east.

The observation of the river near Djenné affords a still more remarkable modification of received opinions; it must now be acknowledged that Djenné stands on an island, and that this island is double; which, let me remark, by the way, may serve to explain many contradictory accounts both of travellers and natives. The new narrative itself is, I confess, not free from difficulties, $I$ have consequently only traced with dotted lines the branches of the river round Djenné. 'The following results may, at any rate, be deduced from $M$. Caillié's routes by land and water, along the eastern part, and from the intelligence which he obtained respecting the western portion; first, that a large branch diverges near Sego, about forty leagues, (in a direct line), above Djenné; and that it re- 
joins the main stream at Isaca, twenty-seven leagues below, (forming the first or largest island, including Djenné); secondly, that near Galia, (or Cou Galia,) is another communication, having itself two branches, and forming a second or smaller island, of which Djenné occupies one extremity; another channel also joins this island with the eastern branch.

This description appears at first sight rather complicated, but its perplexity will be removed if the tracing dotted on the map be admitted. The eastern branch could not have been crossed by Mungo Park, and he knew nothing of it; the same with Dochard. And, as for the second journey of Park, its narrative breaks off abruptly : it is probable that the branch which he followed in the first instance, on which Silla and six other villages beyond Sansanding are situated, is the same branch, which, according to M. Caillié, runs from Sego to Isaca; but Djenné must be carried to the right bank, whereas in the map of Park's travels it is placed on the left. This circumstance was already learned from Baron Roger*; but the new discoveries perfectly explain this contradiction, which is merely apparent; for if Djenné is on the right of the western branch, it is at the same time on the left of the eastern.

This discussion shews that the immense volume of the waters of the Dhioliba is still greater than has been

* Volume II of the Memoirs of the Geographical Society, page 54. VOL, II. 
supposed. Park, indeed, who saw only one branch, stood in silent admiration of this majestic stream; but that which M. Caillié crossed before Djenné and followed as far as Isaca is not inferior to the other in importance*.

The junction of the island with the river, visible from the tops of the houses in Djenné, was pointed out to $\mathbf{M}$. Caillié. Is it with the western arm, or with a branch of the eastern? I am disposed to believe that it is with the latter, the other being at too great a distance to be within sight. I can say nothing positive of the island of Jimbala, and which the maps represent between Lake Dibbi and Cabra, the port of Timbuctoot. There is, however, no reason for doubting its existence, since M. Caillié could not examine all the windings of Lake Debo or Dhiébou, from which an arm may diverge to the right, and rejoin the branch which it runs off to the east near Cabra.

From the travels of $\mathbf{M}$. Caillié we further learn, on the subject of commercial communications, that the navigation of the Dhioliba is almost every where practicable; it is navigable as early as Couroussa, and no doubt yet nearer to its source; there is no reason to suppose any serious obstacle at Bamakou, although there appear to be at this place three principal rapids, but not cataracts. Park

* Speaking of the sight of the river, which he obtained from the heights of Toniba, at four leagues distance, Park exclaims: "I once more saw the Niger rolling its immense stream along the plain." (The Journal of a Mission, \&c. London, 1815, page 143).

+ See Section III below. 
navigated it here; the current, by his account (but on the $22 \mathrm{~d}$ of August, the season when the river is full,) ran at the rate of about five knots an hour. Its bed was a mile in width, and at the point of the rapids twice as much*.

The observations which I have made above upon the position of Timbuctoot apply equally to the course of the river. Ever since the year 1720, the tracing of this course on the maps has been progressively moring from east to west, drawing nearer and nearer to the Senegambia and to the west coast of Africa. It becomes, also, more and more probable that the mountainous space, which separates these two basons, will be found shorter and more practicable for the passage both of men and animals. Who knows but some large tributary to the Dhioliba may run in the close vicinity of a similar tributary to the Bâfing, or even to the Senegal below Galam, such as the Red River, or the Baoulima, or the Kokoro, so that the communication between these two rivers might be established without much difficulty? Who knows, in short, whether the progress of civilization may not one day effect

* Journal of a Mission, \&c., 144, and following pages.

$\uparrow I$ have already called the reader's attention to the fact that $M$. Walckenaer had carried this position at least two degrees farther west than the old maps. Subsequent observations, which I have employed myself in collecting, have proved that a change in this direction was necessary. To judge of its extent it was essential to have good observations taken at Galam, (or at Bakel), as well as a new itinerary between Senegambia and the Dhioliba. It is on these more accurate data that I have endeavoured to work. 
the construction of a canal between such tributaries, suitable for commercial purposes; and whether we may not then find a navigable communication opened between the mouths of the Gambia and Senegal and Sego, Djenné, Timbuctoo, Houssa, and all the large towns by which the Dhioliba flows?

Even though Europeans should attempt only the land passage between the two rivers, this would be an enterprise founded on a more accurate knowledge of the situation and distance of places, and, if not an immediate consequence, would, at least, be an indirect result of M. Caillié's travels on the two banks of the great river. It is unnecessary for me to add, that if, for want of positive documents, I should have erred in tracing the itinerary, the fault will be all my own, and will detract nothing from the merit of our traveller, or from the gratitude due to him from all friends and patrons of discoveries.

To continue our examination of the geographical results of M. Caillié's travels, I ought not to omit the attention he has paid to make himself acquainted with the situation and depth of the wells; a circumstance from which useful inferences may be drawn relative to the course and distance of the waters: he has not neglected remarks upon the climate, the periodical rains,* and the

* On occasion of the rains, the useful assistance he derived from his English umbrella may be remarked, not only for the shelter it afforded him, but for the importance which the natives attached to it, the ad- 
state of the atmosphere. The learned will, no doubt, deeply regret that he was unprovided with instruments for observing and measuring meteorological phenomena: but it is not on a man's first travels that these lights can be obtained; and, besides, none of our readers have forgotten the perils which attended our countryman in the execution of his enterprize.

The situations of several known places experience extraordinary changes in consequence of M. Caillié's peregrinations, without mentioning the towns washed by the Dhioliba. Toudeyni, which was supposed to be $3 \frac{1}{2}$ degrees west of the meridian of 'Timbuctoo, proves by $\mathbf{M}$. Caillié's route to be very near the wells of 'Telig, only $40^{\prime}$ west of that meridian. Is this another place of the same name? I doubt it: its importance, proved by the description given of it by our traveller, repels the supposition. A'raouan* is inscribed in the maps as a mere station, with a well of brackish water; but M. Caillié found this a considerable place, a commercial entrepôt, in a word, an important town, notwithstanding the partial decay of its prosperity.

M. Caillié makes us acquainted in the north with miration it produced, and the advantage he derived from that admiration. This narrative shews that this is one of the portable articles which Europeans would be most certain of exporting with success to Africa.

* The Marabouts write this word 
a place called Oualet, at a great distance from the Walet of Mungo Park, and another of the name of Sala, which confirms the testimony of Arabic writers; in the south the towns of Teuté, Cagny, or Canny, and Koung, fifteen days and more south of Timé, that is to say, near the seventh degree. This account rectifies our notions of the kingdoms or states east of Fouta-Dhialon, and distinctly points out the mountainous tracts, the sandy plains, and the fertile territories enriched by numerous rivers.

We were before uncertain about the district of Bouré; the new notes enable us to give it on the maps very nearly its true site.

The large towns in which he resided, such as Timbuctoo, Fez,* Djenné, Kankan, are very minutely described, and were I not unwilling to lengthen this paper, it would be easy to shew how much he has added in this respect to our information, and also how many false and exaggerated ideas he has corrected: this is a merit for which we ought to give him double credit; since he is, perhaps, of all travellers the one who has dissipated the greatest number of illusions. Sound minds will feel the more grateful to him in proportion to the currency formerly gained by these exaggerations. The lapse of

* See the description of this city in Mr. Jackson's work, quoted above, and that of Timbuctoo, in the Travels of Robert Adams and of Riley, in Leo Africanus, and in the Recherches of M. Walckenaer, \&c. 
time may, indeed, have effccted actual changes in the importance and population of towns; we must not, for instance, be surprized at the difference between the description of Leo and that given at the present day.* Who was there but believed, only a short time since, that Timbuctoo was equal in extent to one of our large cities, and contained within its walls a population of a

* The king of Tombuto, according to Leo, had three thousand horsemen under his command, and an almost innumerable multitude of archers. One very remarkable circumstance is that fire destroyed, according to this author, (if we read oppidi pars) almost half the city in the space of five hours. Leo's recital is the most important, and perhaps the most authentic, of any we have hitherto possessed. These motives induce me to place it entire before the reader, in order that he may compare it with the new narrative. I shall quote the Latin version made from the Italian of Leo (2nd edition), though it is not quite so accurate as might be wished: it is well known that Leo wrote it originally in Arabic. See Joannis Leonis Africani de totius Africæ Descriptione lib, Tiguri, 1559. 431 and following pages.

\section{TUMBUTUM REGNUM.}

Hujus regni nomen nostris ferè temporibus ab ejusdem nominis oppido desumptum volunt, cujus conditorem fuisse dicunt quemdam Mensè-Suleiman, hegiræ anno sexcentesimo decimo: in duodecimo milliario à quodam fluviolo situm fuit, quod è Nigro flumine effluebat; cujus domus omnes in tuguriola cretacea $\uparrow$ stramineis tectis sunt

† These words are not a translation of capanne fatte di pali, coperte di creta, in the Italian text. 
hundred thousand inhabitants, or even from a hundred and fifty to two hundred thousand? The most moderate computation, says M. Walckenaer, gives it a hundred

mutatæ. Visitur tamen elegantissimum quoddam templum, cujus murus ex lapidibus atque calce vivo est fabricatus : deindè et palatium quoddam regium à quodam Granatæ viro artificiosissimo conditum. Frequentissimæ hìc sunt artificum, mercatorum, præcipuè autem telæ atque gossypii textorum, officinæ. Hùc mercatores barbari pannum ex Europâ afferunt. Hujus quoque regionis mulieres faciem tegunt, ancillis tamen exceptis, iisque quæ omnia ad victum necessaria vendunt. Incolæ, ac inter hos exteri præsertim, sunt ditissimi, adeò ut qui jam regem agit, utramque filiam duobus mercatoribus ditissimis in uxores dederit. Frequentissimi hìc putei, qui aquam præbent dulcissimam; ac quoties Niger flumen excrescit, ejus aquam ductibus quibusdam in urbem trahunt. Regio est frumentis, pecudibus, lacte atque butyro copiosissima: salis verò summa est penuria; hùc enim à Tegasa, quod oppidum in quingentesimo abest milliario, adferri solet. Ego cùm hìc essem, vidi salis sarcinam unam, quantùm camelus ferre potuit, octoginta emi aureis. Tumbuti rex opulentissimus bracteas aliquot atque sceptra habet, quorum nonnulla mille et trecentarum sunt librarum. Magnificam optimèque instructam alit aulam : quoties aliquò proficiscitur, camelo insidet, qui à nobilibus duci solet : idem evenit quoties ad bellum proficiscitur; milites verò omnes equites sunt. Hunc si quis regem alloqui velit, ad 
thousand inhabitants.* The exaggerations of the Arabs have constantly held the Europeans under the same error, and in the itinerary of Mohamed-Ebn-Aly Ebn-Foul

pedes primùm procidit, deindè terram sumens in caput atque humeros sternit: soletque hic fère mos ab illis servari, qui nunquam anteà regi sunt locuti, aut qui ab alio principe hùc legati sunt missi. Equitum semper tria millia habet, pedites propemodùm innumeros, qui arcubus sagittas emittunt veneno infectas. Frequentissimè cum his belligerantur, qui tributum persolvere recusant, et quotquot prælio capere possunt, Tumbuti mercatoribus vendunt. Magna hìc est equorum paucitas; mercatores atque aulici pusillos quosdam alunt, quibus in itinere peragendo uti solent; præstantissimi autem equi à Barbaria adducuntur. Rex verò simul atque audit mercatores cum equis appulisse, mox numerum sibi adferri jubet, deindè omnium præstantissimum sibi deligit, pretiumque liberalissimè persolvit. Judæis omnibus adeò se hostem atrocem præbet, ut nullos omninò in ea civitate admittat: si quos Barbaros aliquid cum Judæis commercii habere intelligit, statim illorum bona proscribere jubet. Magna hìc est judicum, doctorum, sacerdotum, atque virorum doctissimorum, copia, qui liberalissimis regiis aluntur stipendiis. Infiniti hìc libri manuscripti ex Barbaria adferuntur; è quibus multò plures pecuniæ quàm ex reliquiis omnibus mercibus colliguntur. Horum moneta aurea est, nullis figuris insignita :

\footnotetext{
* Recherches sur l'Afrique Sept. \&c., page 184.
} 
especially it is said: "This is the largest city which God has created."*

With regard to the account of the mountains of

in rebus autem minutioribus cochleis quibusdam utuntur quæ hùc ex Persarum regione convehi solent, harum quadringentæ aureo æquivalent: aureorum autem sex, cum duabus unius aurei tertiis, unciam unam pendent. Homines naturâ sunt mites atque placidi; à vigesimâ quartâ in primam usque noctis horam cantando atque saltando omnes ferè civitatis partes ambiunt. Mancipia utriusque sexûs quàm plurima alunt: estque oppidum ignis injuriæ maximè obnoxium; ubi jàm secundùm ad hos venissem dimidia ferè oppida pars quinque horarum spatio igne deleta fuit. Nullum in suburbio hortum aut fructibus consitum locum reperies.

\section{CABRA OPPIDUM.}

Cabra sic satis amplum absque muris ad pagi modum compositum oppidum, distat à Tumbuto ad flumen Nigrum

* Recherches sur l'Afrique Sept. \&c., page 184. It is true that this itinerary is less worthy of credit than that of Sheik HaggyCassem, translated by M. Delaporte, the date of which seems to be 1805, and which agrees on many points with M. Caillié. Those who have made this part of Africa the object of their studies will perceive some evident fiction in the former work. 
Fouta-Dhialon, and the means afforded by the descriptions of M. Caillié for forming an idea of the configuration of the country, or the relations which exist between the situations of the different basons, I must refer to what I have said in $\S$ II. (articles 2 and 3 ); I shall also refer to the same for the positions of various countries, pompously called kingdoms by travellers or writers.

Although he did not receive either from government, or from any learned societies, those questions or instructions which might have guided him in his course, $\mathbf{M}$. Caillié has observed much; if he has not treated his subject very profoundly, if indeed he has but glanced at it, he has at leasi opened the road to his successors.

in duodecimo ferè milliario : hìc mercatores ad Gineæ aut Melli regnum navigare cupientes, naves conscendunt. Hujus tàm cives quàm ædificia Tumbuti ædificiis atque civibus non admodùm sunt inferiora : hùc Nigritæ navigio undique confluere solent. In hac civitate Tumbuti rex judicem quemdam constituit, qui lites inter eos componeret : molestum enim erat toties in anno eam ob causam eò proficisci. Ego hìc regis fratrem Abu-Bacr, cognomine Pargama, novi hominem, colore quidem nigrum, cæterùm animo atque ingenio candidissimum. Frequentissimi hìc exoriuntur morbi, qui rempublicam mirum in modum minuunt. Idque propter ciborum ineptissimam commixtionem : pisces enim lacte, butyro atque carnibus commiscent ; estque hic præcipuus ferè Tumbuti cibus. 
It is thus that during his travels he has lost no opportunity of speaking of the manners and customs, of the costume and food, of the people; of their religious practices and superstitions; of their commerce and navigation; of their industry, agriculture, and habitations ; of the population of the countries; of the character, the physiognomy, and the language of the inhabitants; of their warlike or peaceful habits ; in a word, of the whole state of society amongst these still half barbarous people. The picture of a flourishing agriculture, a peaceful and industrious population in the countries of Kankan, Ouassoulo, Baléya, \&c., will be read with peculiar interest. Could it be expected that he should penetrate deeply into these subjects, or even that he could direct his attention to them with benefit?

It would be superfluous here to repeat all the new results for which we are indebted to him, and which make ample amends for the frequently minute simplicity of his accounts; they well depict the difficulties of the journey and the precautions which it requires. Future travellers will not complain of the multiplicity of his details, monotonous, it is true, but convenient in pointing out to them the measures necessary to avoid miscarrying in their enterprize. On this ground M. Caillié will have contributed usefully to the progress of discovery.

The physical conformation of the various races, and the colour of their complexion, are most frequently noticed by our traveller. This is one means of clearing up some 
questions still enveloped in great obscurity, for example, the origin of the Fellatas, as they are called by the latest English travellers. What relation do they bear to the great nation of Foulahs ? We learn from M. Caillié that the Touariks are established much farther towards the south than has hitherto been supposed; their camps are seated upon the Dhioliba, considerably above Timbuctoo. He has also taught us that they bear a second name, that of Sorgous; above all, he has given us some very valuable information respecting the tyranny exercised by this wandering and predatory tribe against the peaceful natives; the portrait he has drawn of them bears visible marks of truth.

With regard to idioms, it is vexatious that M. Caillié, although he visited so many tribes, has been able to collect only two vocabularies. That of Timbuctoo consists of only a hundred and twenty words. We must regret that it is not more extensive. I have already said that the words in Denham's relation agree with him, but not those of Adams and of Bowdich.

The particulars respecting commerce have been col. lected with care. M. Caillié has scarcely ever omitted to point out the native or foreign commodities which he saw at every market, their price, and the kind of coin. He confirms the fact that European merchandise reaches central Africa; goods of English manufacture were to be seen at Djenné as well as at Saccatou. Upon the commerce of Bouré in gold the traveller gives us some in- 
formation which appears to be equally new and certain, and fit, probably, to direct the calculations of speculators, or the efforts of the European governments. We have yet but a vague knowledge of the actual degree of the riches of the mines of Bouré, and the quantity of gold now circulating in commerce ; but there can be no doubt that it abounds in this part of Africa. We know for certain that this rich country is a hundred and twenty or a hundred and forty leagues in a straight line from the establishments of the Gambia and the Senegal. If we could, at some future day, open a direct communication, we should avoid the journey from Bouré to Ségo, from Ségo to Djenné, thence to Timbuctoo, and afterwards to Morocco, across the great desert; not only should we thus shorten the road by at least four hundred leagues in a direct line*, but we should escape the cupidity of the Moors and the Jews, who appropriate the largest part of the profits, and also the ferocity of the predatory Arabs of the desert. At a trifling sacrifice, and in a short time this result might be obtained, if but a small part of those efforts were consecrated to it, which are absolutely wasted upon less useful objects. But, whatever the consequence may be, geography and the genius of discovery will have had the merit of pointing out a source

* From Tangier to Timbuctoo, 450 leagues in a direct line; from Timbuctoo to Bouré 200 leagues, total 650 leagues; with the return 1300. From St. Louis to Caignon 110 leagues; from Caignon to Bouré 120 ; total 230, and with the return 460 : difference in a direct line, 420 , and with the return 840 . 
of wealth to ancient Europe, overcharged wlth debts and population, and ready to sink under this double burden, if some new outlets are not speedily opened to her industry.

If it were possible to doubt the veracity of the traveller; if it could be supposed that all which has been hitherto said has still left any uncertainty in the minds of those who, in the first instance, manifested some incredulity, the results which I have just recapitulated would remain equally doubtful: it is their importance which induces me to neglect nothing here which may dispel doubts, if they still exist. I shall first cite, as a sure testimony of this veracity, an Arabic manuscript which Lander received two years ago from the hands of his master Captain Clapperton, and which M. Salamé translated in London, at the very time that $M$. Caillié was completing his enterprise : it is a description of part of the Soudan. One may read a portion of the African text, with the new map in one's hand, for the countries common to this description and to the itinerary, that is to say, as far as Timbuctoo. I will even add that it would have been completely unintelligible to me, without the assistance of this map*. The alteration in the names of places does not prevent their being recognized; for many of the differences, it appears evident to me, arise only from carelessness in

* See the French translation, by Messrs. Eyriès and de la Renaudière, tome II, supplement, pages 298 , etc. 
copying. I have made an extract from this curious do cument, which was accompanied by a map of the Kouara, traced by the hand of the secretary or amanuensis of the Sultan Bello. I place, according to geographical order, the different parts of the description, extracted as I have said above.

"The route from Sakkatou to Masera crosses first a tributary to the Kouara, and afterwards that river itself.

" The Touara flows from south to north, thence to the east, and afterwards returns to the south.

"It is formed of two arms, the one, called Balio, the black river, coming from the Fouta-Djalo ; the other, called Raniou, the white river, coming from Ségo**

"At their junction it takes the name of Couarra, according to the secretary.

"Upon the first is a large island containing the town of Djeri.

" Many streams fall into the river on the left side.

" Beyond is the lake Djebou.

* The English translation of this document has here joined the countries of Fouta-Torou and Darboz; the latter cannot be San-Salvador, as the translator imagines. 
"Timbuctoo is at the farthest turn of the river : Kabara is half a day's journey from that city.

"Masera is beyond the branch which comes from Ségo.

"The Touariks occupy the country adjoining Timbuctoo to the north, \&c."

I pass over in silence the other places unconnected with the route of M. Caillié, or which he has not mentioned.

This account appeared at first very obscure ; but by reading, with me, Massina instead of Masera, and Djené (or Djenné, instead of Djeri), every thing is explained.

It is easy to confound a noun without a point with a, re. A similar error, I think, has been committed in the name of $B$ a-niou which has been read Raniou taking a be without a point, for a, $r e$.

'The word Dombari, a mountain represented upon the map of the Fellata writer, ought, upon the principle already laid down, to be read in two words Oun-bari.

M. Caillié having informed us that the situation of Djenné is in an island, it will be immediately recognised in that of Djéri, actually situated at seven YoL. II. 
days' journey from Ségo. In like manner, the arm, which separates in the environs of Ségo, says $\mathbf{M}$. Caillié, and rejoins the western branch at Isaca, explains the Balio and the Banio, which meet, (according to the Fellata), below Djéri (or Djenné). Our traveller, not having inquired the names of these branches of the river, could not be acquainted with them. Masera is here, like Massina, to the west of Djenné : I remarked that, in travelling from Timé to Djenné, M. Caillié neither saw nor heard of the mountain or the town of Ounbari, nor of the road leading to Saccatou.

The lake Debo or Debou is here placed as it was seen by M. Caillié, between Timbuctoo and the confluence of the two branches (at Isaca); it is called in the Arabic description Djebou. The name of this great lake is doubtless written جبر, and I suppose that in this word, the $\rightarrow$ is pronounced $d h i$, as at the Senegal. On this subject, I remark that, according to M. Caillié, the name of the town of Djenné is pronounced, in that country, in a peculiar manner, expressed here by Dhienne.

The same is the case with the name of Fouta-Dhialon which the English translator, after the Fellata, writes Fouta-Djalo*. In studying the Arabic nomenclature of

* Similar instances have induced me long since to adopt the $d h$ or $g h$ in transcribing several African names, particularly in the word Dhioliba, independently of the meaning of the word Dhioli, which the natives would probably write

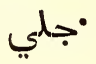


the places bordering on the Senegal, this observation has appeared to me to be more and more confirmed; and it must by analogy be applicable to the neighbouring countries. The Marabouts had only the letter djim $\mathrm{C}^{\text {at their }}$ disposal for expressing this liquid sound, which is of a peculiar nature, intermediate between the English $t h$ and the Arabic $d j$.

The marigots observed by $\mathbf{M}$. Caillie on the left bank of the stream, correspond with the four rivers or canals belonging to Masera or Masina.

Kabera appears here to be placed beyond Timbuctoo (coming from Djenné) : the place in question is perhaps distinct from Cabra; or Timbuctoo may be a little farther west of Cabra than has been supposed. M. Caillié in going to this city went due north by the compass, which places it only $17^{\circ}$ west of Cabra.

With regard to Baniou, White River, it should be remembered that $M$. Caillié also translates in the same manner the word Bagoé, the name of a considerable tributary of the river running from Teuté, very far south, but falling in on the right bank, whereas the Baniou is on the left: there is therefore a difference both in the name and situation. Goé (and koué, according to Mungo Park) certainly signify white in Mandingo. But the words niou and lio, I cannot find in any vocabulary of Northern Africa, with the meaning of white and black. In Wolof, moul signifies black. 
The Banimma of the maps cannot flow parallel with the great river, as I have explained above*.

It would not be uninteresting to compare with this draught the pretended map of Bello himself, which Clapperton has given in his first travelst. Five or six sites only are connected with my subject; Djenné is here, as in the other, placed between two branches of the river, (a fresh point of conformity with our traveller) and the Massina is separated from it by the western branch. There again the $r$ is substituted for the $n$; (and I presume for the same reason) for it is there spelt Jesni or Jenri, and Mashirał.

For want of room, Bello has placed Sego and Masina, much too near together, as well as Fouta and Djenné. The city of Timbuctoo (written Tonbaktou) is not less misplaced by the august geographer; but he has marked between it and Mashira (Massina) a large tributary or offbranch : this is probably one of the four rivers which his secretary has indicated in the same space, and one of the

* I have however somewhere seen this name translated by Black River; the Banimma is marked on the eastern side, as well as the Balio.

$\uparrow$ The Narrative of Travels and Discoveries in Northern and Central Africa, by Major Denham and C. H. Clapperton. London, 1826, page 109 of Clapperton's journal.

$\ddagger$ I perceive also the name of Jerry amongst those of the districts subject to Mohammed-Labou: (Massina, Temboctou, Jerry) does this name stand for Jenné ? 
marrgots, the outlet of which was seen by M. Caillié*. Thus the only two native maps (if they may be so called) which we possess, and the recent descriptions of two Africans, all confirm the discoveries of M. Caillié, who was entirely unacquainted with them.

A corroborative testimony is that of Park himself. Similar names will be found in the two narratives for certain indigenous productions and for several instruments employed in the arts. The Mandingo words and names are either the same or analogous in the two narratives.

In a preceding article, I think I have sufficiently shewn the agreement of M. Caillié's observations with those of other distinguished travellers, Mollien, Watt, and Winterbottom, and Major Laing. The particulars of Major Laing's death collected by our traveller at Timbuctoo, and afterwards on the very theatre of the catastrophe, so far from contradicting those obtained either by the English Consul at Tripoli, or by the governor of the Senegal, confirm all the important circumstances of botht.

We did not learn from the first travels of Clapperton the name of the prince reigning at Timbuctoo ; it was even imagined that the supreme authority resided at that period in a female; and when M. Caillié informed us that the

* The comparison of these two African maps with the accounts of Isaaco and Amadi-Fatouma, Mungo Park's guides, affords results not unworthy of attention : but I have not room to deduce them.

† See “Quarterly Review." See also “ Réflexions sur l'état des Connaissances relatives au Cours du Dhioliba, page 27 . 
supreme chief of Timbuctoo was named Osman, we could not reconcile this report with those which had preceded it: but we have now letters from Major Laing himself, received since the return of our countryman, one of which dated from Timbuctoo, the 21st of September, 1826, reveals the name of the prince then reigning, and this name is also Osman*.

In the same letter, Major Laing states the circumference of the city at four miles; this account confirms the small population assigned to it by M. Caillié. He adds that he has collected documents in abundance relating to Timbuctoo. If we may rely on the account of a Moor from Saint Louis, the books of the Major are at the disposal of a certain Saleh, son of the Iman of 'Timbuctoo; and according to another they are in the hands of the Touariks. Time will in all probability produce some of the documents, the only consolation for so deplorable a loss.

The same accuracy appears in M. Caillié's observations respecting the journeys, if we admit as a fair specimen those which concern countries whose geography is known ; thus the distance from Fez to Arbate by Mequinaz agrees with the itinerary of M. Caillié, at the rate of three miles an hour.

So many motives of confidence and interest sufficiently recommend the accuracy of the travels, and consequently 
authenticate the results $I$ have above deduced; yet the history of the enterprize itself will, if possible, increase this effect. The inclination of Réné Caillié for travels of discovery early announced his vocation. From the moment of his second landing at Senegal, he employed himself in acquiring a familiarity with the language of the Moors.* $\mathrm{He}$ talked of nothing but penetrating into the interior of Africa, the object of all his thoughts ; his resources became exhausted, yet he refused every other occupation, every other mission. This fixed impression was regarded as a mania ; nothing could shake his purpose, not even the insults which his Moorish costume drew upon him from the negroes; he was content to be considered by them as an idiot, and almost an object of derision. The want of sufficient support having obliged him to take another course, he set out for Sierra-Leone ; there he remained the period necessary for collecting some resources, and soon quitted it for Rio-Nuñez : thence he announced to a friend at St. Louis (in April 1827) his departure for the interior. He was supposed to be lost, and nearly forgotten like so many other victims, when, at the expiration of eighteen months, he suddenly appeared at the further extremity of Africa, triumphant over every obstacle ; like an expert swimmer, who, having plunged into the bosom of a broad stream, after a long interval unexpectedly appears on the opposite bank, while his friends are already lamenting his loss as certain.

* See above, Vol. I, the account of his first travels. 
Scarcely had he quitted the banks of the Rio-Nunez and entered upon this new career of difficulty and danger, when he at once displayed a consunmate prudence, and far above his years : as skilful in appreciating obstacles as he was firm in encountering them, his embarrassments increased at every step; but his sagacity constantly suggested the means of extricating himself from every new perplexity. Had he not possessed this just estimate of his difficulties and resources, united with a fortitude not to be shaken, he could not have concluded, perhaps not have commenced, his enterprize. How ingenious was the fiction he invented to obtain the confidence of these numerous tribes! This thread, slender as it was, served every where for his guidance and protection. He rightly supposed that the fame of the French expedition to Egypt had spread over Northern Africa: it was natural that a child carried off from its parents at the age of three years, and transported into the heart of France, should be but ill versed in his mother-tongue ; equally so that good Musulmans should congratulate him on his return to his country by the most direct line, although he was supposed to be destitute of resources. Now this line must inevitably conduct him beyond the great river : afterwards manifesting a desire of repairing to Alexandria by sea, it was necessary to return to the river and embark on it, and thus his arrival at Timbuctoo was accomplished with certainty; having attained this object, he must naturally seek the readiest and surest means of reaching some place occupied by Euro- 
peans, and the caravan of Tafilet offered an opportunity that he could not hesitate to seize.

I shall not advert to all his misfortunes at Timé, and during the journey, nor to his perils at Tangier, when already within sight of his haven ; but with what intelligence and courage must he have been endowed to resist and triumph over so many enemies. It was necessary to avoid the most trifling error; a single one would have infallibly proved his destruction.

Few are acquainted with the history of the unfortunate Antonio Piloti, a Spaniard, who took refuge in Morocco in consequence of the political events of 1811. After having assumed the Moorish dress, and habituated himself to the language, he succeeded in enrolling himself amongst the Emperor of Morocco's guards. Incessantly occupied with the project of going by this means to Timbuctoo, he secretly offered his services to the French consul, M. Sourdeau; he solicited the protection of the French government: the consul had ascertained that he combined all the qualifications essential to success, yet his offers were rejected. Neverthless Piloti daily prosecuted his preparations for the journey : nothing it should seem could have prevented his success, since he would have set out under the disguise of a Moor, and returned with a caravan of Moors. In the absence of direct assistance from France, he was furnished with instructions by M. Delaporte, our vice-consul, and from a member of the Geographical Society, who was on 
the point of sending to him some instruments, when he was suddenly implicated in the political movements of the court of Morocco. The Moors and Jews, always intriguing, suspected some secret designs on his part, and denounced him as belonging to the party opposed to the prince. His trial was summary, and Piloti was beheaded. Such is the jealous distrust manifested by the mercenary race, against any stranger, who, making himself acquainted with the localities, should attempt to deprive them of any portion of their commerce with the interior. M. Caillié, ignorant of this adventure, was more fortunate; he did not continue long enough exposed to the suspicions of the Moors, or by prudence and sacrifices he contrived to escape the effects of them.

On the first arrival of the letters which I received from M. Delaporte and M. Caillié himself, I entertained some doubts of the authenticity of his narrative, and I immediately arranged some questions by way of trial, on the language spoken at'Timbuctoo, the customs of the country, its natural productions, the nomenclature and distance of places, \&c. : but meanwhile I attentively compared the two letters, and found the result so conformable to the most established notions of science, that I determined to publish on that very day the news of the journey to Timbuctoo. Many were incredulous; I expected it. I requested the traveller, who in the interval had landed at Toulon, to commit to paper without delay his recollections respecting the questions which I held in readiness for his arrival, but to which 
he had beforehand in a great measure replied. The very day of his arrival he submitted to my inspection a journal of his travels complete, and continued from the 19th of April 1827 to the 21 st of September 1828, modestly observing : "I do not know whether I can answer all your questions, but here are my notes." He then shewed me part of the original notes, written in pencil, on the spot, and the narrative written and completed during his residence at Tangier and in quarantine, though suffering under a high fever. He also shewed me the pieces of cord with which he had measured the meridian shadow at Timbuctoo and in other places, some fragments of plants brought from the interior, the vocabularies, and some simple sketches of the town of Timbuctoo. If after such testimony I could retain any doubts, the construction of all the routes of the traveller, which I drew up on the following day, would have effectually dispelled them, for I discovered that the observations were continued without any interruption, and that the whole produced a result agreeing with the data already acquired.

It remained that the learned Geographical Society should share my conviction, an additional success for which M. Caillié had not long to wait; * and he obtained a brilliant recompense which he had amply merited. This

* On the 8th of October he arrived in France, five months after his departure from Timbuctoo ; from this time the period of his com- 
example will restore confidence to minds discouraged by so many fatal catastrophes; and will inflame the zeal of those who are actuated by a desire for glory and the advancement of geographical science.

pulsory residence in Morocco must be deducted. The Geographical Society awarded to him its highest premium at its general meeting on the 26 th of December 1828, only seven months after he quitted Timbuctoo. 


\section{V.}

OF THE COURSE OF THE DHIOLIBA ABOVE AND BELOW TIMBUCTOO.

The attentive reader who may have patiently followed me through the preceding pages, will, no doubt, have remarked the new and principal fact which results from M. Caillié's observations ; the division of the Dhioliba in the environs of Sego into two branches equally broad and deep, and the existence of a large island. It elucidates the description of Mungo Park, and reconciles him with our traveller; it explains the contradictions between the situations assigned to the same towns by different travellers, sometimes on the right, and sometimes on the left of the river, and finally it enlarges our ideas of the advantages of navigation in the interior of the Soudan. This fact also accounts for the great collection of waters which forms the lake Dhiebou or Debo, because many considerable branches which separate from the western arm unite again with the main stream beyond the tributary which falls into it at Isaca ; and the want of declivity in the direction of this junction is the cause of the stagnation of the waters.

It would appear that the river has different names which change with its course. Called at its source Tombia, $B a$, 
Dlioliba, \&c., it retains the latter name as far as Sego, where or in the environs it divides; if we may trust the description of the amanuensis of Bello, the left arm is called Baniou, and the right Balio, and after the junction it is called only Couara. But M. Caillié never once heard that the river, which he reached at Galia, and upon which he navigated thirty days, had different names; perhaps because he did not inquire. He only saw a river, Couaraba, which falls into the right branch, but very far to the south. I think then that if the stream is called Couara below Isaca, it is only because the term is generic and signifies a river.

I might stop here and leave it to the reader to draw other consequences from the new observations. But the question of the outlet of this stream is so closely connected with my subject, that the reader would have a right to complain if in this work he found neither information nor opinion upon it. It is universally inquired what becomes of this immense collection of water below Timbuctoo; it is at least necessary to exhibit in a few words the different opinions at present current upon this subject.

The most ancient identifies this river with the Nile of Egypt. It does not appear that the partisans of this opinion had any other foundation than the pretended unanimous reports of blacks, Arabs, and natives. Thus without considering the physical conditions, or taking account of insurmountable obstacles, they maintained as a fact, that the waters which had their rise in the heights of the Souli- 
mana, that is to say at an elevation of from fourteen to fifteen hundred feet, reached the Mediterranean after a course of two thousand leagues. But, what is perhaps still more strange, this notion rested wholly upon the equivocal interpretation of a word, or as we may express it in plain English upon a pun; the word Nile or Nil is generic. In saying that the Dhioliba joins the Nile, the Africans mean no more than it communicates with some other great water, whether it falls into it, or whether it receives it, (for this distinction of arm or tributary is very important). When therefore the Arabs say that the Dhioliba communicates with the Nile or the Bahi, they understand thereby either a great river, or a sea, and this may be an inland sea as well as the Ocean. This opinion that the Dhioliba empties itself into the Nile of Egypt, though it was supported only a few years since by a learned writer, appears to be now altogether abandoned.

But this is not the case with the opinion of those who, like Major Rennell, consider the central lake as the outlet of the river. Before the discovery of the lake Tchâd by the English travellers, the existence of this inland sea might have been doubted, the evidence of it was so vaguely attested. This opinion, however supported by probability, is nevertheless liable to two objections: first, that upon the whole western coast of the lake is found the mouth of only one inconsiderable river, the source of which is at no great distance in the E. S. E.; secondly, that the town of Boussa, to which Park navigated upon the Dhioliba, is now known by the second 
journey of Clapperton, and that it is very far to the S. E. of Timbuctoo.

With regard to the first objection, it may not prove a serious difficulty, because recent travellers have not followed the river Yéou, which falls into lake Tchad; they have left it at a certain distance from the lake, and it is very possible, that that which they have seen farther on may have been only a tributary to the former. As to the second objection, it might be more important if it were certain that the Dhioliba runs in a single bed from Timbuctoo to Saccatou and to Boussa; but there is nothing to prove this. Continuing eastwards, towards the central lake, it may send out a branch to Boussa; and this division would account for the Yéou consisting of but an inconsiderable body of water.**

Reichard was one of the first who imagined that the Dhioliba may run into the Gulf of Guinea. This hypothesis has for some time past assumed a certain degree of probability, to which the opinions of the later English travellers, Clapperton and Major Laing, $\uparrow$ have added much weight. They differ, however, respecting the outlet of the river : the one preferring the river Benin (or For-

* It was during the dry season that the English travellers found it to be a hundred yards wide; but it is very broad at other times.

+ The late Malte-Brun adopted this opinion immediately after the publication of the English travels to Saccatoo. 
$\begin{array}{llllll}\text { THE } & \text { COURSE } & \text { OF } & \text { THE } & \text { DHIOLIHA. } & 369\end{array}$

mosa), with Reichard*; the other, but with much less probability, the Rio-Volta. The objection always raised to this hypothesis is the great height of the mountains called Kong. To reach the sea, the river must cross them; but it may not be absolutely impossible that there should exist an opening in them deep enough to admit of its passage. Another difficulty arises from the small declivity of these waters : but $\mathbf{I}$ will here make an observation on this subject. The actually known course of the Dhioliba, from its source as far as Timbuctoo, is about three hundred and sixty leagues: it issues from Mount Loma, at a height of nearly sixteen hundred English feet above the sea, or less than five hundred metres. The velocity observed by $M$. Caillié leads to the belief, that the average inclination from Djenné and also from Bamakou to 'Timbuctoo is two thirds of a metre to a league : Timbuctoo would stand, according to this datum only, at a height of two hundred and sixty metres; but it is very probable, that the inclination is much greater from Mount Loma to Bamakou than it is below this latter point, which would lower the position of Timbuctoo at least to two hundred and thirty metres, taking the fall of the first part at only a metre for a league. But this quantity would greatly exceed that supposed by Capt. Beaufort, who, after having observed the elevation of Elimané, conceived Timbuctoo to be upon the same level, that is to say, eighty-four metres above the sea.†

* See Ephémérid. Géogr. for the year 1803.

+ Is it possible to quote this estimable traveller, who united so voL. II. 
Now, from Timbuctoo to the mouth of the river of Benin, following the course of the waters (as it is traced by the partisans of this opinion), the distance is not less than four hundred and sixty leagues. Thus, in the second part of its course, the river would have a total declivity of 230 metres, or 0,51 metre to a league. It is known that the Seine has an inclination of 0,72 metre to a league; the Mississipi, 0,84 metre; the Rio-Apure, 0,92 metre, \&c. but others have a much less fall, such as the Wolga, the Missouri, the Senegal, \&c., which have one of 0,50 only ;* so that, strictly speaking, the above inclination is sufficient.

According to a fourth opinion, the river, on reaching the Kong mountains, makes an elbow to the left and runs eastward, by Djacoba and Adamowa to Chary, and thence to lake Tchad into which it discharges itself. It is here that the objection of the want of sufficient inclination applies : how can it be admitted, that the river, after passing Funda, where it would scarcely have an elevation of fifty metres $\uparrow$ above the sea, (supposing it to be the river of many extraordinary qualities, without offering a tribute of regret to his memory? His loss has deprived science of more than one discovery : all, however, has not perished with him; the account of his travels has been preserved; and it is to be hoped that it will speedily be published, with his maps and drawings.

* See Mémoire sur la Communication du Nil des Noirs avec le Nil d' Egypte, p. 9.

$\uparrow$ Funda appears to be less than a hundred leagues from the sea. measuring the distance by the current. 
Timbuctoo which flows to Funda), can run on to lake Tchad, three hundred and fifty leagues farther, through a country represented by all accounts as mountainous? But this, even, is not the greatest difficulty.

It is hardly conceivable that any geographer should have admitted an hypothesis, the absurdity of which must have been manifest upon the slightest reflection. The height of lake Tchad has been ascertained: it is nine hundred and twenty French feet above the level of the sea, or something less than three hundred metres; it cannot, therefore, receive the waters which flow to Funda.

The course of this river east of Funda must be reversed, and the supposed elbow converted into a tributary: we shall then probably approach the truth. Major Denham was the first to conceive this easterly turn of the river, running north of the great chain of mountains, and falling at a great distance into the central lake; he had been assured that a communication existed between this river and lake Tchad by the Chary. How is it that the physical impossibility of this course did not occur to him ?

A very simple consideration appears to afford a solution of this difficulty, namely, the existence of a lake in an elevated point of the Mandara chain, giving rise both to the Chary and the river which flows by Adamowa 
and Djacoba. The reports made to Major Denham demonstrate the importance of this stream, which is sufficiently proved by its extent; but, why, without ocular testimony, did he imagine its course to be easterly? If the negroes did not inform him that it ran to the west, neither did they state the contrary. Let us admit the westerly direction: a certain communication will then exist also between the Couara and the Chary; only, after having descended a current southwards, we must ascend another eastward, and thence redescend northwards, into the central lake. This is the most plausible theory I can devise upon Major Denham's opinion; this is nearly the case with the White Nile and the Misselad, both taking their rise in one of the lakes of Gebel-Koumri. Upon this system, the Couara will continue, after the confluence, to flow southwards, and fall into the sea near the coast of Benin.

A fifth opinion has been recently broached by the English General Sir Rufane Donkin; * the summary of which is that the Niger crosses the Wangarah, enters the valley of Ouadi-el-Ghazel, formed by the continuation of the Misselad, and thence runs into the Mediterranean (in the great Syrtis) by a subterranean channel under the sands of Bilmah; and moreover that the Niger rises near the Gulph of Guinea, instead of running towards it. This

* A Dissertation on the Course and probable Termination of the Niger. London, 1829. 
THE COURSE OF THE DHIOLIBA. $3: 3$

rather extraordinary opinion has met with adversaries, at which we need not be surprised, even after having read the arguments on which the dissertation is founded. I do not therefore think it necessary to discuss it here; neither shall I enter into the complicated notions, upon the courses of the central river, hazarded by the English traveller Bowdich on very vague information; and I shall be cautious not to offer an additional hypothesis of my own respecting this problem, still full of obscurity. On what basis can an entire and complete system be founded while even the names of the central regions are unknown to us, and our researches into the physical geography of these vast tracts are yet in their infancy; when, in short, the papers of Major laing, should they be recovered, may at once throw strong light on these chasms in science ?* It may however be affirmed and I think with certainty, that the rivers called Dhioliba and Couara neither join the Egyptian Nile, nor contribute one drop to its waters; I think besides that, if the Couara of Funda actually is the continuation of the Dhioliba, flowing to Sego and Timbuctoo, and falls into the Gulph of Guinea, there is nothing to hinder it from throwing off a branch to the east, which may have its

* M. Chauvet, however has just published a conjecture coinciding with several different accounts, and possessing the advantage of embracing the whole question of the rivers which traverse Northern Africa in every direction : his opinion is developed at great length, and I should here insist. upon the merit of this explanation, had not the author prevented me, by quoting my opinion as an authority. (Revue Encycl. October 1829). 
outlet in the Yeou and the central lake : this would be the branch seen by $M$. Caillié before he reached Timbuctoo, and which our traveller followed, the other being on his right flowing east-south-east; and there is no proof that the whole of the former rejoins the latter. The great lake Tchad, or central sea, would then not be the general receptacle of the Dhioliba, but only one of its outlets. 


\section{CHAPTER II.}

VOCABULARIES COLLECTED BY M. CAILLIÉ.

Compared with those of Mungo Park, Bowdich, Jackson, Denham, \&c.

1.

\section{ENGLISH AND MANDINGO VOCABULARY.}

N. B. These words are in use from Timé to Jenné, as vvell as in the Western districts.

\section{NUMERALS*}

$\begin{array}{ll}\text { One, } & \text { Kili (killin) } \cdot \uparrow \\ \text { Two, } & \text { Fila (foula). } \\ \text { Three, } & \text { Saba (sabba). } \\ \text { Four, } & \text { Nani (nani). }\end{array}$

* The numerals are the same as in Bambara.

$\uparrow$ I have added within parentheses the words given by Mungo Park to shew the frequent agreement between the two travellers, the differences arise from the diversity of the countries through which they travelled.

It is to be regretted that travellers, when collecting the words of an unknown language, do not select peculiar and characteristic terms : it would be easier, by following this method of comparing the different id:oms, to discover their family resemblance or their original dissimilarity. With this view, I have formed a rather extended specimen of a vocabulary principally for the use of travellers in Africa, with a methodic mode of interrogation (See Atlas Ethr. de M. Ad. Balbi, page xlviij. 
Five,

Six,

Seven,

Eight,

Nine,

Ten,

Eleven,

Twelve,

Thirteen,

Fourteen,

Fifteen,

Sixteen,

Seventeen,

Eighteen,

Nineteen,

Twenty,

Twenty-one,

Twenty-two,

Twenty-three,

Twenty-four,
Loulou (loulo).

Ouaro (ouoro).

Ouaro oula (oronglo; in

Bambara, ouoloula)*.

Segui (sie ; in Bambara, seguey).

Kenando (konounta).

Tan (tang).

Tan ni kili (tan-ning killin).

Tan ni fila.

Tan ni saba.

Tan ni nani.

Tan ni loulou.

Tan ni ouaro.

Tan ni ouaro oula.

Tan ni segui.

Tan ni konando.

Mouga.

Mouga ni kili.

Mouga ni fila.

Mouga ni saba.

Mouga ni nani.

I have also formed a collection of vocabularies of more than thirty idioms of Northern Africa, which may serve as a second part of the $V_{0-}$ cabulaire des Voyageurs.-E. J.

* The $r$ is changed into $l$ in this word and many others see below.E. J. 
Twenty-five,

Twenty-six,

'Twenty-seven,

Twenty-eight,

Twenty-nine,

Thirty,

Forty,

Fifty,

Sixty,

Seventy,

Eighty*,

Ninety,

A hundred,

One hundred,

Two hundred,

Three hundred,

Four hundred,

Five hundred,

A thousand,

Two thousand,

A hundred thousand,
Mouga ni loulou.

Mouga ni ouaro.

Mouga ni ouaro oula.

Mouga ni segui.

Mouga ni konando.

Bi-saba.

Bi-nani or débé.

Bi-loulou or débé ni tan.

Bi-ouaro or débé ni mouga.

Bi ouaro oula or débé ni mouga ni tan.

Bi segui or kemmé.

Kemmé ni tan.

Kenmé ni mouga.

Kemmé kili.

Kemmé fila.

Kemmé saba.

Kemmé nani.

Kemmé loulou.

Ba kili.

Ba fila.

Ba kemmé.

* The third numeral order of the Mandingoes, called kemmé, and which answers to a hundred, is composed of only eight tens; so that our hundred is equal to their hundred and twenty, which they express by kemmé ni mouga (a hundred and twenty). Their hundred being only eighty, their thousand is equal to eight of our hundreds. 
A.

All,

Amber,

And,

Ant,

Ass,

Bad,

Baked,

Beginning,

Belly,

Black,

Body,

Break (to),

Breeches,

Bridge,

Broom,

Brother,

Bruise,

Butter,

Butter (vegetable),

Buy (to),

Carrier,

Cassava,

Cat,

Cataract,

Chief,

Child,
Abé (bee).

Doucan.

$\mathrm{Ni}$ (ning).

Magnan.

Soféri.

B

Adiougou, amagne (jou).

Amo or amoe.

Folo, folou.

Kono, (kouno).

Fin (fing).

Moho or Mojo.

Teguet.

Kourouci.

Salan or Ceou.

Sira.

Dahokai (badingkea).

Sousou.

Toulou.

Cé to’xlou.

Soro (saun).

C

Donita.

Balancou.

Sou-horo or soujou (neancou).

Souroudo.

Mansa or tigui.

Din-din (ding-ding). 
Colats (fruit),

Cold,

Cold (a cold, having a cold),

Come here,

Cotton,

Cotton thread,

Country,

Country of the whites,

Coussabe (part of th dress),

Cow,

Cow-grass (species of),

Cowries,

Crowd or support,

Cultivation,

Cut (to),

Dance,

Day,

Death,

Dispute,

Dog,

Door,

Draw (to),

Drink (to),

Duck,
Ourau.

Nene (nino).

Sojo-sojo.

Ana yan.

Koroni.

Koroni-kina (ouorondi).

Dougou (dou).

Forto dougou.

Dourequi.

Nici mouso (nessie mousa)

Fogni or faini.

Kolo.

Adigui.

Senekai.

Teguet (tegi).

D.

Doukai.

Tele (tie-.lie),

Faja (asuta).

Kailai (degama).

Ourou (ououla).

Da (da).

Afouare.

Mi (amean).

Toucono. 
F.

Ear,

Earth,

East,

End,

Enough,

European,

E.vening,

Eye,

Far,

Fat,

Father,

Fear,

Female,

Festival,

Fight (to),
Fought,

Finish,

Fire,

Flint,

Fly,

Following,
Da.

Dougou (banko, koungokoulo).

Tilibo (tie-lie-bo).

Atto.

Ateuté (keyento).

Forto, or Christian-nassara.

Oula.

Ya (nea, guiè).

F.

Adiau (jangfata).

Abo (aouarata).

Fa (fa).

Kissi.

Mouso (mousa).

Douno.

Bouga (agossi).

Lodé or tadé.

Ta (tassema, diemba).

Caba.

Simo-ho, or simojo.

Sicin, diaun. 


$$
\text { MANDINGO VOCABULARY. }
$$

Foot,

Forest,

Full,

Girl,

Give,

Give me,

Glass-ware, beads, \&c.

Go away,

Go below,

God,

Going (I am),

Gold,

Gourd,

Grain,

Grass,

Gun,

Gunpowder,

Hair,

Hand,

Have (I have some),

Have not (I have none),

Head,

Heat (of the atmosphere), Atara.

Heat (from fire),

Heavy,
Cé, (lee sing).

Cong or oula.

Fada.

G.

Mousa (ding-mousa).

So.

Adiamau.

Kouo.

- Yaoua.

Tahata or tajata.

Alla, (alla)

Bedaoua.

Sanou (sanou).

Fia.

Din.

Binoung (jambo).

Metfa, cannon in Arabic.

Metfa moucou.

H.

Cé.

Bron or Brou (boutou).

Abéfé.

Atéfé.

Cou (koung, koun).

Akala.

Kadiougou. 
Hen,

Hole,

Honey,

Horse,

Hot,

House,

How much,

Hungry (I am),

Kidney-beans,

Knife,

Know (I)

Know (I do not)
Cice (sousie mousa)

Dâ* (dinka)

Ly (lee).

So (sou).

Kala (candiata).

Bon, bon (boung).

Diougue.

Kong abefé (konkola).

K.

Soso.

Mourou (Mouro).

Akal or abelo.

Amantoyolo or amanlo.

L.

Leap,

Leaf of baobab,

Leather or skin,

Leather bag,

Liar,

Little boy,

Little girl,

Load,

Lost,
Broue.

Sila broue.

Boulo.

Sourgo or sassa.

Kadojo.

Dindin.

Din mouso.

Doni.

Fry.

\footnotetext{
* An opening in general. See the note, page 384.
} 
M.

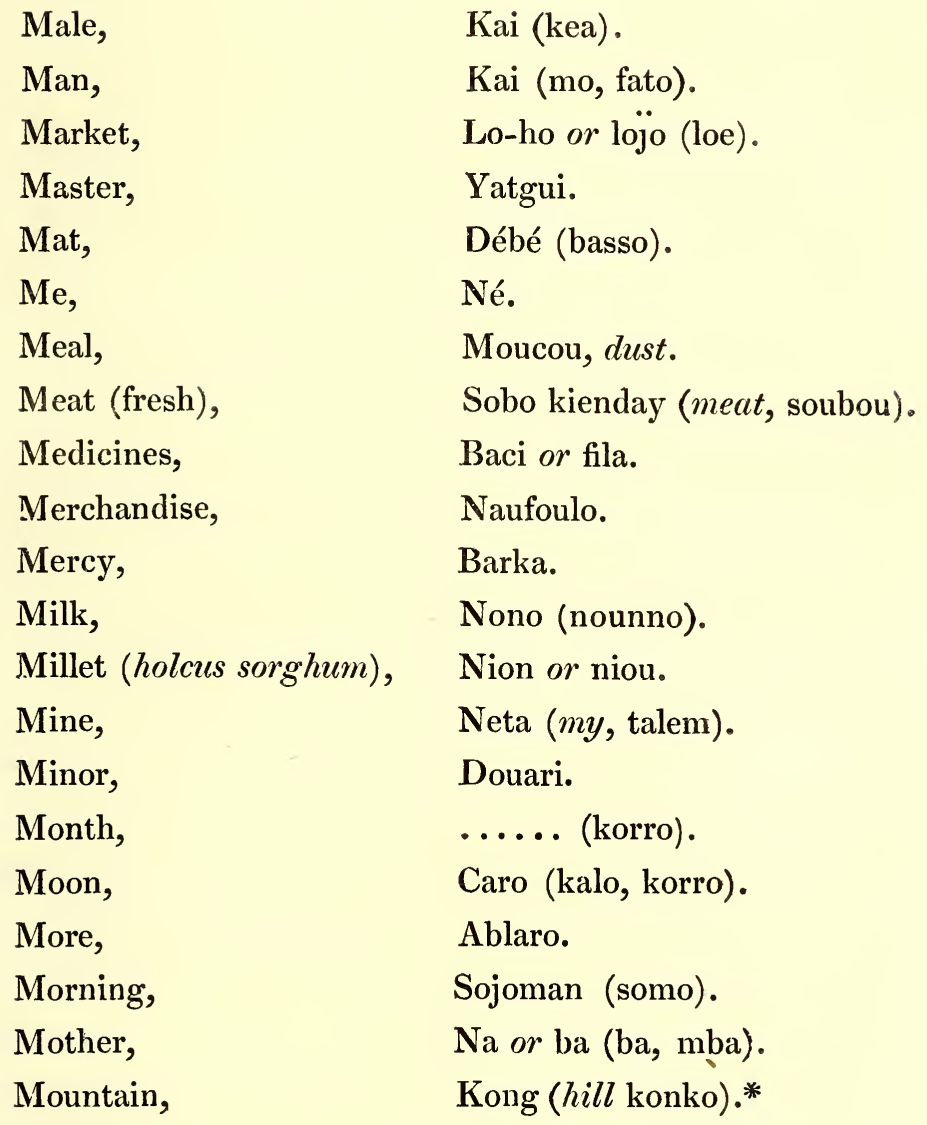

* M. Caillie has observed that the word mountain is expressed by kong. Mungo Park has taken a generic term for the name of a particular mountain; Park himself here confirms my observations, by giving the word konko. I may add that the term for head is koung in Mandingo ; and there is an analogy in the sense.-E. J. 
Mouth,

Much,

Mutton,

Needle,

Night,

No,

North,

Nose,

Oil,

Opening,

Overflow (of a river)

$\mathrm{Ox}$,

Padlock,

Pannier,

Paper,

Part, (let us),

Path,

Pirogue, (a boat),

Pistachio nuts,

Pot

Powder, dust,
Da (ba, da).

Siéman (sitimata).

Saha or saya.

N.

Méséri.

Soudo (soutou).

Té or até (inta).

...... (saheel).

Nou (nou, noung).

O.

Toulou (toulou)

Dâ*.

Abo.

Nici.

P.

Boro.

Seigui.

Caïda (coïtou).

Yaoua.

Sila.

Ba counou,

Tiga.

Da-ha or Daja.

Moucou.

* This word also signifies mouth, no doubt because it expresses that which opens, the ear, the mouth, the door, or any other opening. 
Q.

Quarrel,

Rain,

Razor,

Read (to),

Rice,

Rice (baked)

Rich, rich person,

River,

River overflowed,

Rivulet,

Road,

Route,

Salt,

Sand,

Sandals,

Sangleh (food in use in Se-

negal).

Sauce,

Says (he)

Scarlet,

Scissors,

Scrape (to),

See (to)

Seen (I have),

Seen (I have not),

vOL. II.
Lailai (quiata)

Sangui (sangie water from above).

R.

Lila.

Garan (toulima).

Maro.

Baya,

Nanfoula tigui.

Bâ (ba).

Ba abo.

Coua.

Sila.

Sila (seelo).

S.

Noyo (coo, ko).

Fri (kini-kini).

Sabata (samata).

Tau.

$\mathrm{Na}$ 。

Ko.

Morofi.

Mécécou or ticera.

Siim.

Ye (eagie).

Akabéyé.

Aman Yéba.

$2 \mathrm{C}$ 
Sell (to),

Sensible,

Sew (to)

Sewing thread,

Shadow,

Short,

Sick,

Silver,

Sister,

Sit down,

Skin,

Slave,

Slave (female, )

Slave (male),

Sleep (to),

Small,

Softly,

Song,

Source,

South,

Speak (to),

Spoon,

Stones,

Stuff,

Sun,

Sweep, (come and)
San.

Kadojo.

Kara.

Kari (bori).

Douran.

Doc ho (sutto).

Ademi (meun kinde).

Ouari (cody).

Coro (ba ding mousa).

Sigui (sie).

Boulo (goulo).

Yug or youg (joung).

Youg mouso.

Youg kai.

Sino-ho or sinojo (sinou).

Ado-ho or dine (miessa).

Doi-doi.

Soucou.

Folo (origin).

...... (boulla ba).

Coma or couma (akoummo). Kausora (dosa).

Courou (bino).

Fany.

Télé (tlé or tie lie).

Anabou sira.

T.

Take (to),

Thief,
Ta.

Suinlikai (soun). 
Thine, Heta.

Thou or you, Ilai.

Thou art called,

Bedacrila.

Throw, Fry.

Throw (to), Fry (fi).

To-day, Bi (bie).

To-morrow, Sini (sinni).

To-morrow (the day after), Sini kindé.

Tooth, Gui.

Travelling (he is),

Abesilaré.

U.

Understand (I do not),

Amamé or Atemé.

V.

Village,

So.

W.

Walk, to walk,

War (dispute),

Wash (to),

Water,

Water, (fresh,)

Wax,

Weaver,

Weight,

Well,

West,
Ta-ha or taja (tama).

Kailai (killi).

Kaw (kou).

Gui or ghi, dhy, gie*.

Gui sema.

Cagnan.

Dari.

Ka diougou (akouliata).

Ba.

..... (tie lie gie).

* The $g u, g h$, or $d h$, has here a guttural sound.

2 c 2 
Where are you going?

Where is it?

White,

White, (complexion),

White man,

Wind,

Woman,

Wood,

Wooden dish or bowl,

Writing,
Taja menez ?

Menez?

Goé (koui).

Goé.

Forto (or nosaro Arabic).

Foignan (feunnio).

Mouso (mousa).

Lo-ho or lojo*

Goïng, (the $i$ pronounced hard and through the nose.)

Siberi.

Y.

Cou.

San.

Naime, (aoua, Arabic).

Counou (kouna).

Counaucini.

Ilai, (eeta, ee)†.

\section{SHORT PHRASES IN MANDINGO.}

Is the country of the Mandin- Mandingua dougou a kagoes far off? diau?

It is not far off.

Amadiau.

* The $\ddot{\mathrm{j}}$ is used here, and in all the words that should have a strong guttural pronunciation; it is in the Spanish $j$, and the Arabic $\dot{\check{c}}^{\text {, kha. }}$

+ Inta, in Arabic, thou. 
Give me fire,

Give me sandals,

What does he say?

To kill an ox,

I will come to-morrow,

My heart aches,

Have you nothing to give me Até fin diamaubi. to-day.

I am going to wash some Ataja fany kau. linen,

I am hungry,

I am satisfied,

Come with me,

Stay here,

Go and sit down in the Ataja sigui so kono*. house,

Will you come with me into Abégue taja néfé Mandinga the Mandingo country?

The road is bad, it is very Sila adiougou dé, courou,

stony, and there is much gui, abefef. water,

Come and eat some rice, Ana maro doume.

I can eat nothing now, I am Até fin fin doume, cuin not hungry, afada.

All the slaves are gone to till Youg abé taja sénéké. the ground,

Ata diamau.

Assabata diamau.

Kodit ?

Nici faya or faja.

Adina cini.

Koug abéfé.

Afada.

Ana néfé.

Asigui yan.

dougou?$$
\text { afada. }
$$ 
Warm the water; word for Ablagui tafé. word, put the water upon the fire,

When it is warm you may Akakala kadiaman. give it to me,

I will wash my body, Abégue mojo kau.

The value of a piastre. Lankons.

I am fatigued, Aségué.

Let us rest ourselves, Asigui doudine.

The dinner is upon the fire, Tau abétafé.

There is nothing here, Fin fen até yan. Something, Fin fen (fouké).

Give me some water, A gui diaman.

Bring me some warm water, Ana gui kala. Do you speak Mandingo ? Is that to be sold?

How do you do? Ka Mandinga kou ?

Very well, I thank you, Adi san.

Take care,

Get out of the way,

Come and eat some meat,

Put it upon the fire,

I am going into the village, What do you call that?

I do not know,

That is called......

It is true,

Enekiendaï?

Baraba. Akaitou. Agoé sila. Aua sobo doume. Abla tafé boudou. A taja so--fé. Tiez tojo di. Aman tojo lo*. Atojo...... Okai.

* I do not know the name of that. 
It is not true,

Seek it,

It is short,

Blow your nose,

It is done,

That will heal it,

It is healed,

It is not dressed,

Are you well ?

Do not cry,

It is ready,

It is not ready,
Até kai.

Fouré.

Kadojo.

Enoukai.

Abinda.

Adiba.

Abinda.

Amamoéba.

Akiendai ?

Amaukou.

Bedacé.

Amancéba. 
II.

\section{ENGLISH AND KISSOUR VOCABULARY.}

Spoken at Timbuctoo, and upon the Banks of the Dhioliba, as far as Djenné.

NUMERALS.

$\begin{array}{ll}\text { One, } & \text { Afau, (affoo, D.)* } \\ \text { Two, } & \text { Ainka, (nakinka, D.) } \\ \text { Three, } & \text { Aindhia, (nahinza, D.) } \\ \text { Four, } & \text { Ataki (attakee, D.) } \\ \text { Five, } & \text { Tgou, norgou (aggoo D.) } \\ \text { Six, } & \text { Tgou (iddoo, D.) } \\ \text { Seven, } & \text { Yé (ea, D.) } \\ \text { Eight, } & \text { Ya-a (yaha, D.) } \\ \text { Nine, } & \text { Yaga (yagga, D.) }\end{array}$

* I have added between parentheses many words of the language spoken at Timbuctoo, according to Captain Lyon and Major Denham : these last are accompanied by the letter D.; it is remarkable that they are all confirmed by M. Caillié, and at the same time scarcely one of the others. The words given by Robert Adams to M. Dupuis are in the same predicament as those of Captain Lyon. This disagreement alone cannot prove the falsity or the travels of Adams; but it is at least well worthy of attention. See above Chap. 1. \$1.-E.J. 
KISSOUR VOCABULARY.

Ten,

Eleven,

Twelve,

'Thirteen,

Fourteen,

Fifteen,

Sixteen,

Seventeen,

Eighteen,

Nineteen,

Twenty,

Thirty,

Forty,

Fifty,

Sixty,

Serenty,

Eighty,

Ninety,

A hundred,

A thousand,
Oué, noroué (auwy, D.)

Oué kindi fau (auwy kind ofoo, D.)

Oué kindi inka ( - linka, D.)

Oué kindi indice ( - linza, D.)

Oué kindi taki ( - - takee, D.)

Oué kindi igou ( - aggoo, D.)

Oué kindi idou, ( - - iddoo, D.)

Oué kindi yé ( - ea D.) Oué kindi ya-a ( - yaha, D.)

Oué kidda yaga, (- - yagga, D.)

Ouaranca-fossi or tobee (warunka, D.)

Ouarandia (warunza, D.)

Oué taki (woytakkee, D.)

Oué gou (way oggoo, D.)

Oué dou.

Oué yé.

Oué ya-a.

Oué yaga.

Yangoufou.

Yangoué. 
A.

Amber,

And,

Ass,

Saca.

Kindi (kind, D.)

Forka (furka, D., chaïd).

B.

Bad,

Beard,

Fante (affootoo, D.; ferri).

Breeches,

Bring (to),

Butter,

Kabi (kabi, D.; heti).

Buy (to),

Sibi, (seeby, D.)

Kati (kata, D.)

Gui.

Daye.

C.

Camel,

Vio (Yeo, D.; so, B.*); elgimmo.

City,

Koyera (agherri)

Come, Ka (kaa, D.; ka).

Coussabe,

Cowries, $\uparrow$

Darbi.

Kolo.

D.

Dates,

Garbi.

Drink (to),

Nine (ushti)

* According to Bowdich.

$\uparrow$ A shell which passes for money. 
E.

Earth,

Ganda (gunda, D.)

Eat (to),

Lem-lem* (ngha, D.)

Evening,

Kiki (keegee, D., night).

Eye,

Nemodé (eye: aiti, D. the

$$
\text { eyes : Moh-inka, D., aiti) }
$$

F.

Fire,

Fish,

Foot,

Full,

Give,

Glass-ware, beads, \&c.,

Go (to),

God,

Gold,

Good,

Gourd,

Grass,
Nonnez (jarrec, D. ; ofi).

Harihau.

Nakidi (kay, D.; odthi).

Acongo.

G.

Néau.

Hiri.

Koyé (koey, D.)

Yalloye (Allah).

Hora (oora, D.; agreef ; dodi).

Agouman (aboree, D.)

Tio.

Sobo.

* This word is perhaps meat in Arabic, taken for the act of eating, in consequence of an error similar to that noticed at the word hand. 
H.

Hand,

Handsome,

Head,

Heaven,

Hen,

Honey,

Horse,

House,

How much,

King,

Knife,

Little,

Look (to),

Man,

Meat,

Merchandise,

Milk,
Lamba (kambah, D.; akood*).

Koro, tienta (belle).

Homo (bongo, D.; agodi).

Bini (engi).

Grougo. •

Yiho.

Bari (barree, D ; aïs).

Ho (hoo, D, dah, B ; bactoo. Morgue.

K

Tigini.

Simi (hoorie, D).

L.

Kini-kini.

Emagouno.

M.

Harre (harree, D; jungo, abinda, B).

Ham (hum, D ; taasoo).

Almane.

Oi (wah, D ; alebsi).

* Or akhod. This is an Arabic word which signifies take; the motion of the hand has doubtless been taken for the hand itself. 


$$
\text { KIS SOUR VOCABULARY. }
$$

Millet,

Moon,

Morning,

Mortar,

Mouth,

Much,

Mutton,

Nose,

Not,

$\mathrm{Ox}$,

Pagne (a piece of cotton Thiugo.

cloth worn over the dress).

Pestle,

Pirogue,

Pot,
Haine.

Idou (hitte).

Soubah (Arabic),

Popo tondi.

Mi (mey, D ; fetti).

Abeau.

Firgui (fagee, D; taili).

N.

Nini (hoshti*).

Aci.

O.

Haou (hou, D).

P

Tendi.

Heï.

Cousso.

* The resemblance of this word to ushti, to drink cannot fail to be here remarked. Is it not the position of the hand in the act of drinking which has caused the confusion made by Capt. Lyon?-E. J. 
$\mathbb{R}$

Rain,

Rice,

Rich,

Rise,

River,

Sabre,

Salt,

Sangleh, (see the Mandin- Tasso.

go vocabulary),

Sell (to),

See (to),

Shadow,

Shoe,

Silver,

Sit down,

Slave,

Slave (female),

Slave (male),

Sleep (to),

Small,

Snuff box,

Stone,

Sun,
Bana.

Mau.

Almankoye.

Teune.

Hissa (issa, D ; bori).

S.

Takeba.

Kiri.

Nira.

Emagouno.

Sa sa.

Tamo* (tarno, D).

....(n'surfa, D).

Gro.

Banïa.

Coumou (kongo, D).

.... Bunneea, D).

Kani (anti).

Kini-kini (katch).

Bata.

Toudi.

Ouena (offitti, D).

* This should, no doubt be the same word, tarno or tamo. 
T.

Tobacco,

To-day,

Water,

Well,

Wind,

Woman,

Wood,
Sira.

Hau.

W.

Hari, (hary, D ; boca) ami

B.

Bangou (bungo, D).

Héou.

Honi (weey, D, jumpsa, afintoo, B.)

Toucouri (togoolee, D; esheri).

SHORT PHRASES IN THE KISSOUR LANGUAGE.

How do you do ?

I am well,

What is your name?

What is this?

What do you wish?

I wish nothing,

Go away, run,

Open the door,

Who is there?

Kindle some fire,

Bring some water,

There is none there.
Ouandagare ?

Delanfia.

Makin néure ?

Makin-makin ?

Neouri makin ?

Eno ouri méné yaya.

Koyé.

Fère.

Main nono ?

Dem nounez.

Kati hari.

Acibara. 
There is some there,

I am not satisfied,

Go fetch or bring some Koyé hati nounez. fire,

Go to bed,

Go to bed, and to sleep, Grokani.

How do you do this Ene soubah? (Arabic.) morning ?

I am well,

I will,
Abara.

Aci congo.

Gro.

A lanfia sidi.

Abegué. 
OBSERVATIONS ON THE MANDINGO AND THE KISSOUR.

\section{Note.1.-Upon the Mandingo.}

It appears that the syllable $f e$ is the sign of the preposition upon, in, or with, and that this preposition follows the substantive; examples tafe, on the fire; nefe, with me; sofe, in the village; silafé, on the road, \&c.

Negation is expressed by até or té; yet there are many words of a negative sense, preceded only by $a$ or $a m$.

The syllable $k a$ seems to be used for the purpose of expressing to be, whether positively or interrogatively.

The word will or to will is not in the vocabulary; but the phrases present an example of the use of the word abegue in this sense. Besides, the vocabulary of Timbuctoo gives abeg'ue for I will.

The relatives who, which, what, are neither indicated in the vocabulary nor in the phrases; but tiez stands for what, in the phrase, what do you call that?

I have added the word name, which was not in the vocabulary, from the three phrases, tiez tokhodi, aman tokholo, atokho....

VOL. II. 
Note 2.-On the Kissour.

It appears, by several short phrases in Kissour, that the word makin corresponds with the relative who, or what; neare with the word name; ouri or neouri, with to desire. I have inserted in the vocabulary some other words furnished by the phrases.

The vocabulary of Major Denham is composed of sixty-seven words, without the numbers; M. Caillié's of ninety. Forty words only are common to both; but the two correspond almost throughout; it is the same with the numerals : this fact is remarkable. On the contrary, as I have said, the words of Adams, Bowdich and Lyon, differ entirely from those of M. Caillié. 


\section{H A P T E R I I I.}

\section{C A I LLIE'S I T I NER A R Y.}

\section{FROM KAKONDY TO TANGIER BY TIMBUCTOO.}

PART THE FIRST; FROM KAKONDY TO TIMÉ.

\begin{tabular}{|c|c|c|c|c|}
\hline DATES. & $\begin{array}{l}\text { D I R E C T I O N } \\
\text { of the route according to } \\
\text { the magnetic north. }\end{array}$ & {$\left[\begin{array}{c}\text { Number } \\
\text { of miles } \\
\text { travelled } \\
*\end{array}\right.$} & NAMES O PLACES. & OBSERVATIONS. \\
\hline $\begin{array}{l}1827 . \\
19 \text { April. }\end{array}$ & $\begin{array}{c}\text { S. S. E. } \\
\text { E. } \frac{1}{4} \text { S. E. } \\
\text { S. E. then E. } \\
\text { E. } \\
\text { E. S. E. } \\
\text { N. E. } \\
\text { E. } \frac{1}{4} \text { N. E. } \\
\text { E. } \\
\text { N. E. } \\
\text { E. N. E. } \\
\text { N. E. } \frac{1}{4} \text { E. } \\
\text { E. N. E. } \\
\text { E. } \frac{1}{4} \text { S. E. }\end{array}$ & $\begin{array}{c}2 \\
12 \\
2 \\
7 \\
1 \\
1 \\
1 \\
1 \\
1 \\
3 \\
1 \\
1 \frac{1}{2} \\
4\end{array}$ & 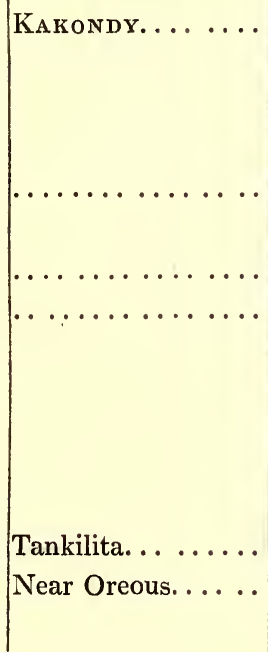 & $\begin{array}{l}\text { Departed from Kakondy at } 9 \\
\text { A.M. with a small caravan of } \\
\text { eighteen persons (one being } \\
\text { a woman) all on foot and } \\
\text { laden. } \\
\text { Halt about } 1 \text { o'clock. } \\
\text { Halt and rest for the night. } \\
\text { Set off at } 5 \text { A. M. } \\
\text { Halt at } 11 \text { o'clock. } \\
\text { Set out at } 20 \text { 'clock. }\end{array}$ \\
\hline
\end{tabular}

* The English mile is intended ; the traveller having, before he quitted SierraLeone, acquired the habit of estimating his march, in a given time, according to a space measured in English miles.

All the other details of the route, and those which relate to the accidents of the soil, are noted in the journal of the travels to which it will be necessary to have recourse in order fully to understand the circumstances of the march. 
I T I N E R A R Y.

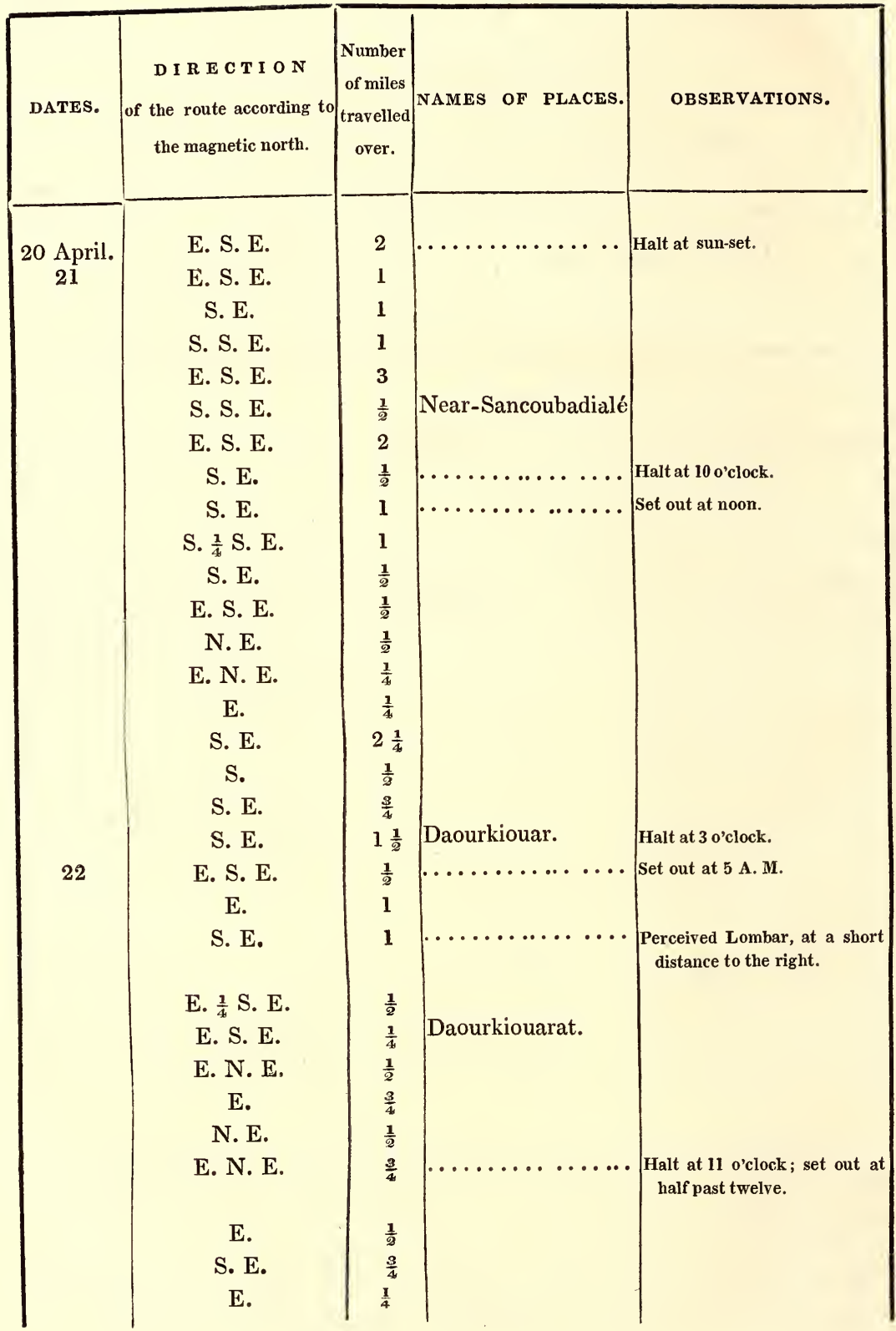




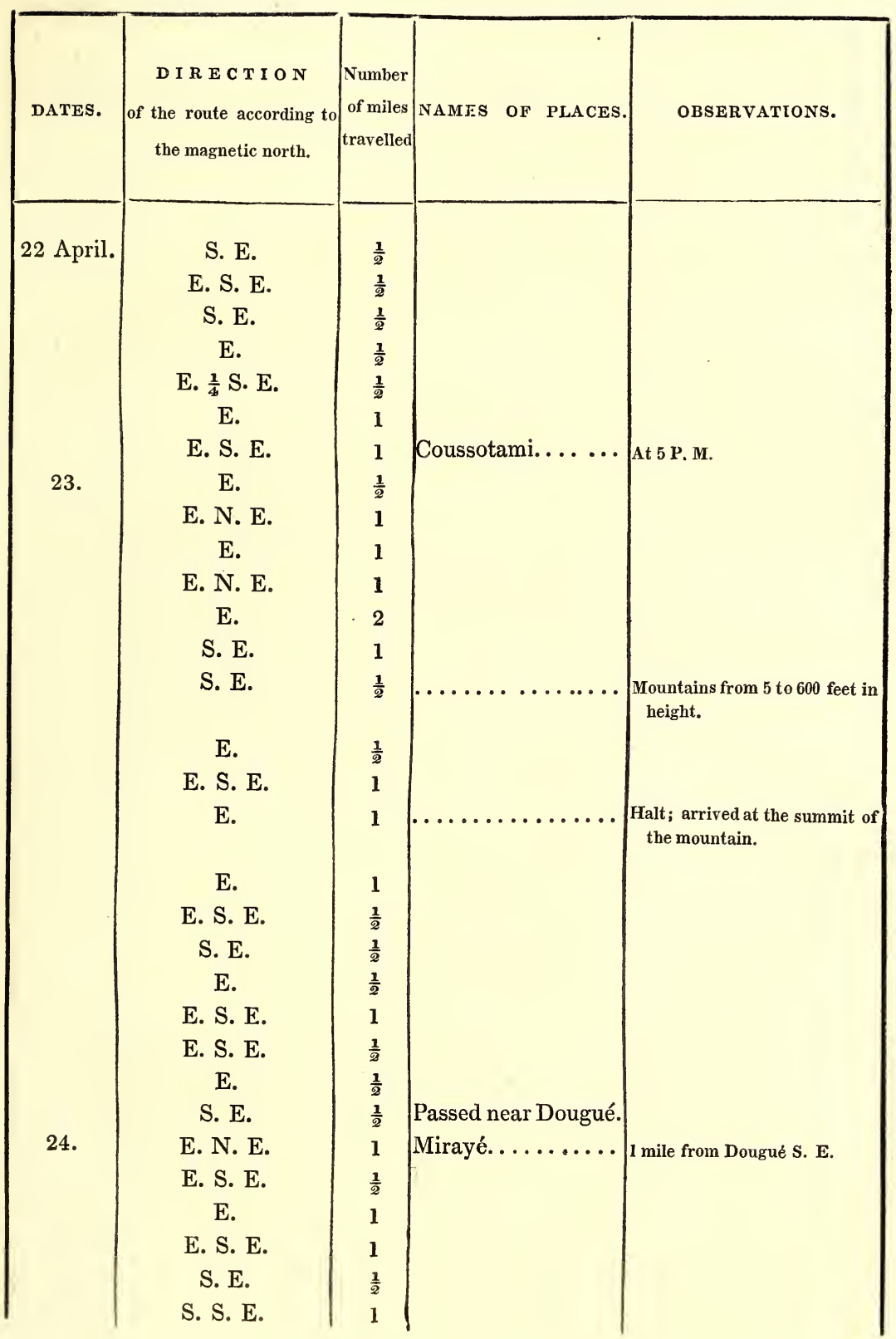




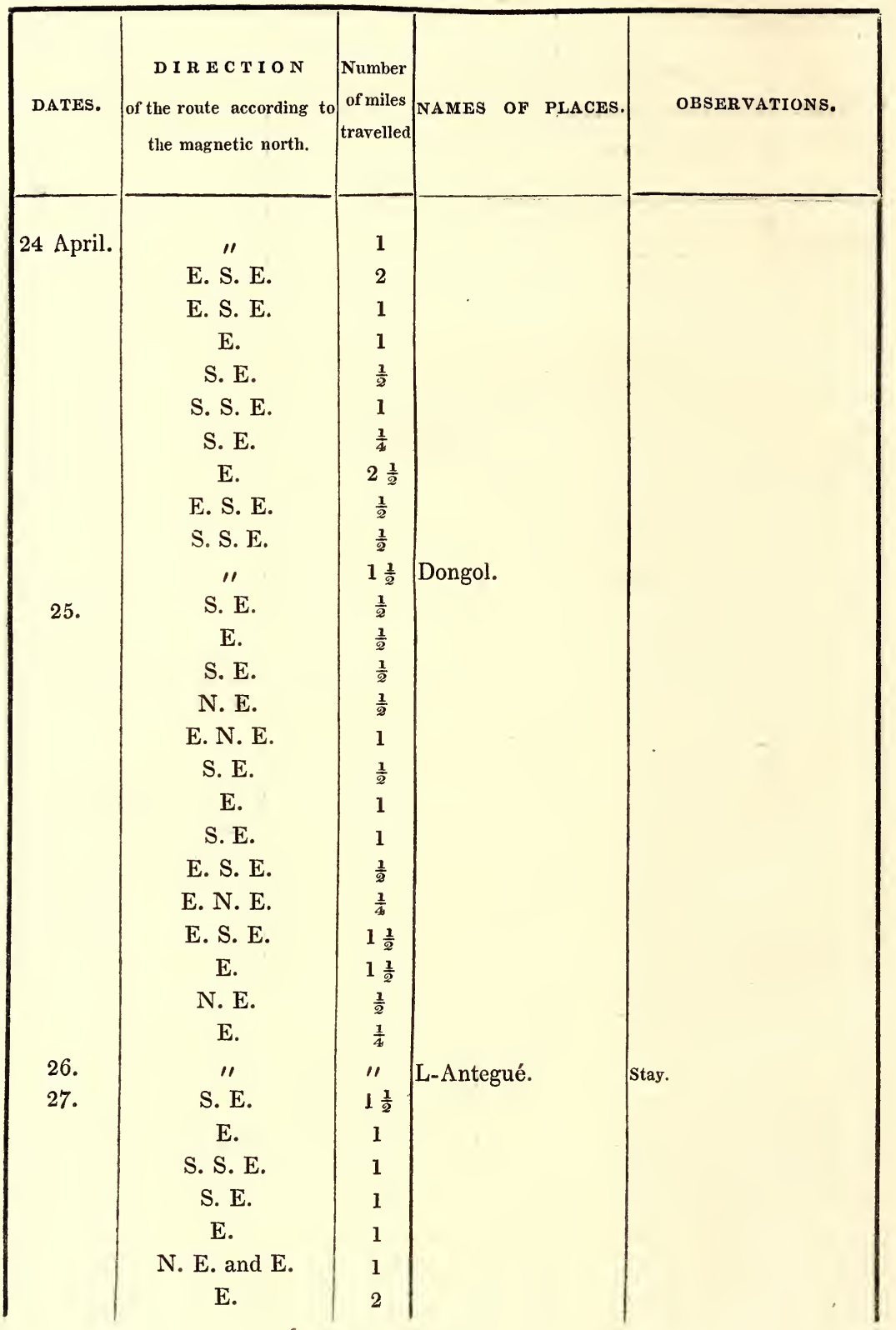




\begin{tabular}{|c|c|c|c|c|}
\hline DATES. & $\begin{array}{c}\text { D I R E C T I O N } \\
\text { of the route according to } \\
\text { the magnetic north. }\end{array}$ & $\begin{array}{c}\text { Number } \\
\text { of miles } \\
\text { travelled }\end{array}$ & NAMES OF PLACES. & OBSERVATIONS. \\
\hline $\begin{array}{l}28 . \\
29 .\end{array}$ & $\begin{array}{l}\text { E. S. E. } \\
\text { E. S. E. } \\
\text { N. E. } \\
\text { E. S. E. } \\
\text { E. } \\
\text { E. } \\
\text { E. S. E. } \\
\text { S. S. E. } \\
\text { E. } \\
\text { E. N. E. } \\
\\
\\
\text { E. } \\
\text { E. N. E. } \\
\text { E. } \\
\text { S. E. } \\
\text { E. S. E. } \\
\text { S. E. } \\
\text { E. } \\
\text { N. E. } \\
\text { E. } \\
\text { E. } \\
\text { N. E. } \\
\text { E. S. E. } \\
\text { E. S. E. } \\
\text { S. S. E. } \\
\text { E. S. E. } \\
\text { E. } \\
\text { E. S. E. } \\
\text { E. S. E. } \\
\text { E. }\end{array}$ & $\begin{array}{c}2 \\
1 \\
1 \\
1 \\
\frac{1}{2} \\
1 \\
\frac{1}{2} \\
\frac{1}{2} \\
\frac{1}{2} \\
1 \\
1 \\
2 \\
2 \frac{1}{2} \\
1 \\
1 \\
1 \\
1 \frac{1}{2} \\
\frac{1}{2} \\
1\end{array}$ & $\begin{array}{l}\ldots \ldots \ldots \ldots \ldots \\
\text { Courgin. } \\
\text { Comi-Sourignan. } \\
\text { Teleouel. } \\
\ldots \ldots \ldots \ldots \\
\text { Bouma-Filasso. } \\
\text { Marca. } \\
\text { Gueré-Temilé. }\end{array}$ & $\begin{array}{l}\text { Volcanic stones. } \\
\text { Climbed a mountain from } 5 \text { to } \\
600 \text { feet in height called } \\
\text { Touma, separating the coun- } \\
\text { try of Irnanka from Fouta- } \\
\text { Dhialon. } \\
\text { The road to Labe, which is } \\
\text { two days' march to the N. E. } \\
\frac{1}{4} \text { E. }\end{array}$ \\
\hline
\end{tabular}




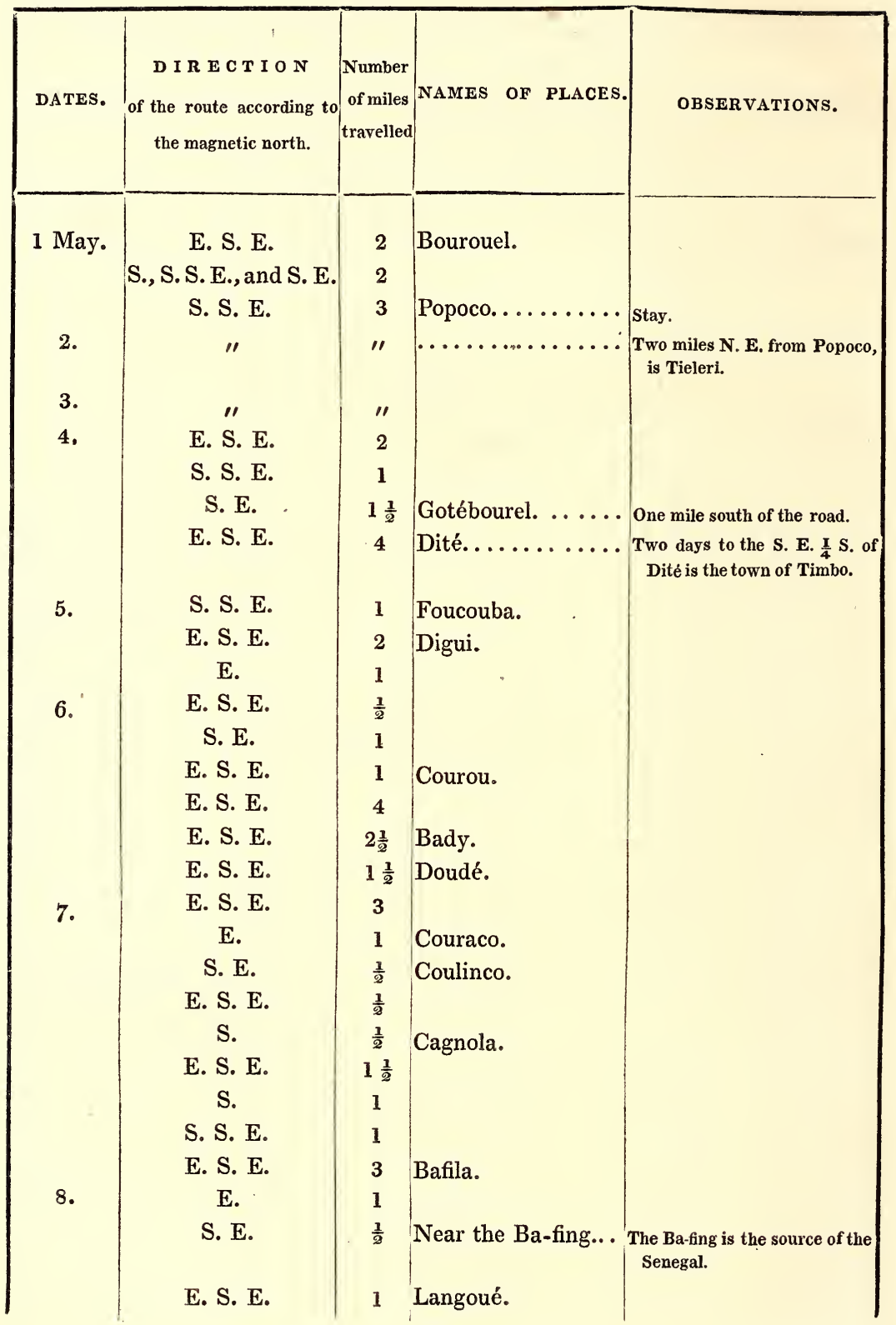




\begin{tabular}{|c|c|c|c|c|}
\hline DATES. & $\begin{array}{c}\text { D I R E C T I O N } \\
\text { of the route according to } \\
\text { the magnetic north. }\end{array}$ & $\begin{array}{c}\text { Nurnber } \\
\text { of miles } \\
\text { travelled }\end{array}$ & d NAMES OF PLACES. & OBSERVATIONS. \\
\hline 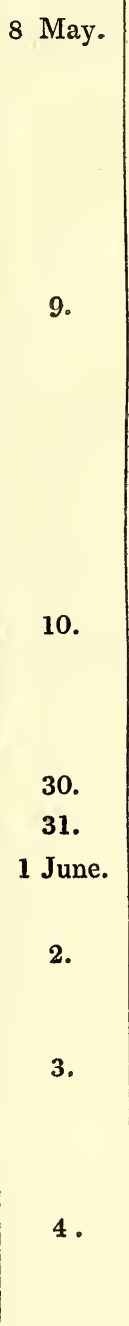 & $\begin{array}{c}\text { S. E. } \\
\text { S. } \\
\text { S. E. } \\
\text { E. } \\
\text { S. E. } \\
\text { E. } \\
\text { S. E. } \\
\text { E. S. E. } \\
\text { E. N. E. } \\
\text { E. } \\
\text { E. } \\
\text { E. } \\
\text { S. E. } \\
\text { '” } \\
\text { S. E. } \\
\text { E. } \\
\text { E. } \\
\text { E. } \\
\text { "' } \\
\text { S. E. } \\
\text { E. } \\
\text { E. } \\
\text { E. S. E. } \\
\text { E. } \\
\text { E. } \\
\text { E. } \\
\text { S. E. } \\
\text { E. } \\
\text { E. } \\
\text { S. E. } \\
\text { E. }\end{array}$ & \begin{tabular}{c|c}
$4 \frac{1}{2}$ \\
1 \\
1 \\
$\frac{1}{2}$ \\
1 \\
1 \\
$\frac{1}{2}$ \\
$2 \frac{1}{2}$ \\
1 \\
3 \\
3 \\
$2 \frac{1}{2}$ \\
5 \\
11 \\
$1 \frac{1}{2}$ \\
3 \\
3 \\
$2 \frac{1}{2}$ \\
11 \\
4 \\
3 \\
1 \\
4 \\
10 \\
1 \\
3 \\
1 \\
10 \\
$\frac{1}{2}$ \\
$2 \frac{1}{2}$ \\
3
\end{tabular} & $\begin{array}{l}\text { Foudédia. } \\
\text { Dimayara. } \\
\text { Fela............ } \\
\text { Foramanca...... } \\
\text { Sanguessa. } \\
\text { Cambaya........ } \\
\text { Bagaraya. } \\
\text { Socodatakha....... }\end{array}$ & $\begin{array}{l}\text { A Mandingo town. } \\
\text { A little to the left of the road. } \\
\text { Plain of Kankan-Fodea. Here } \\
\text { the caravan divides. Stay. } \\
\text { Halt. }\end{array}$ \\
\hline
\end{tabular}




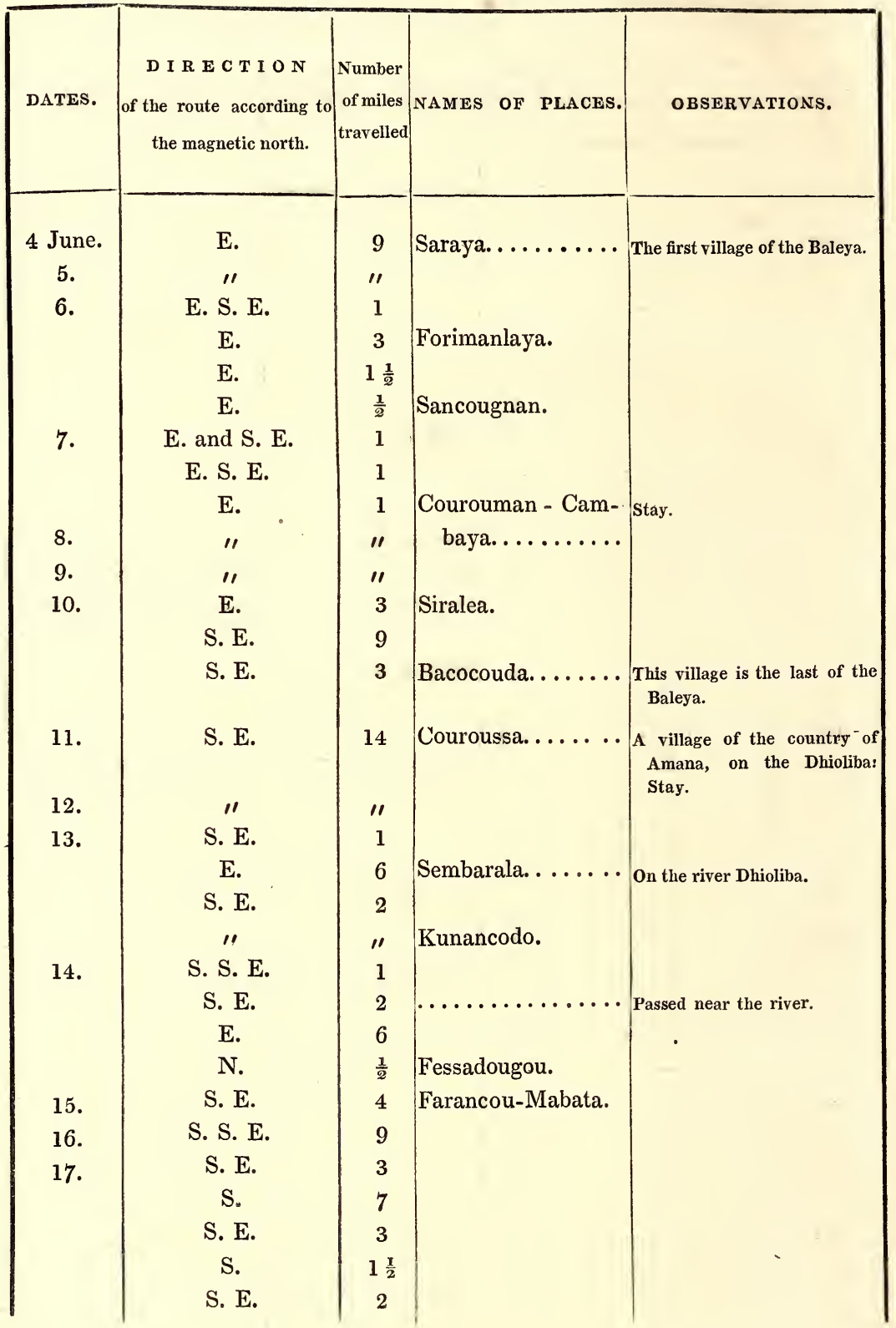




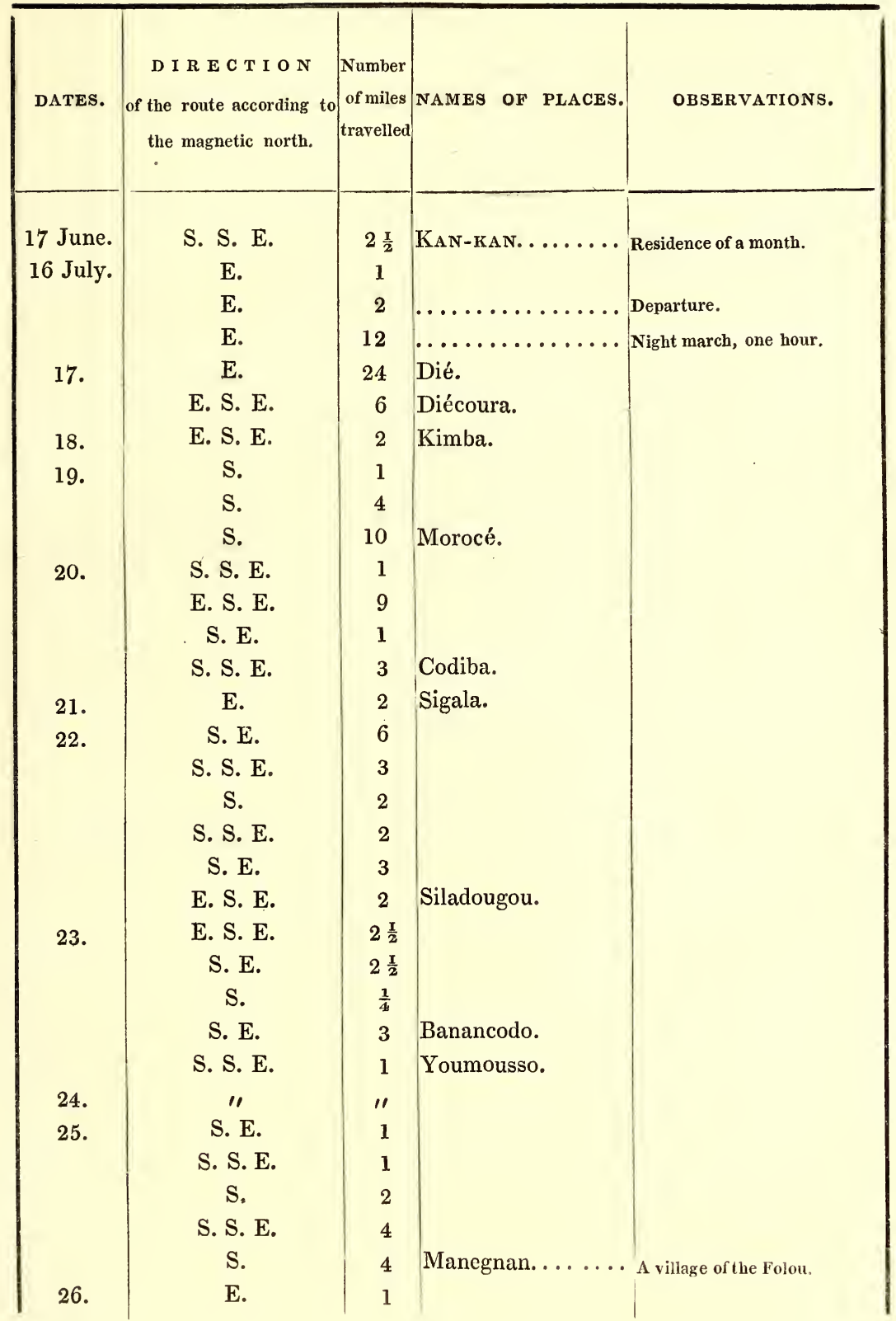


I T I N E R A R Y.

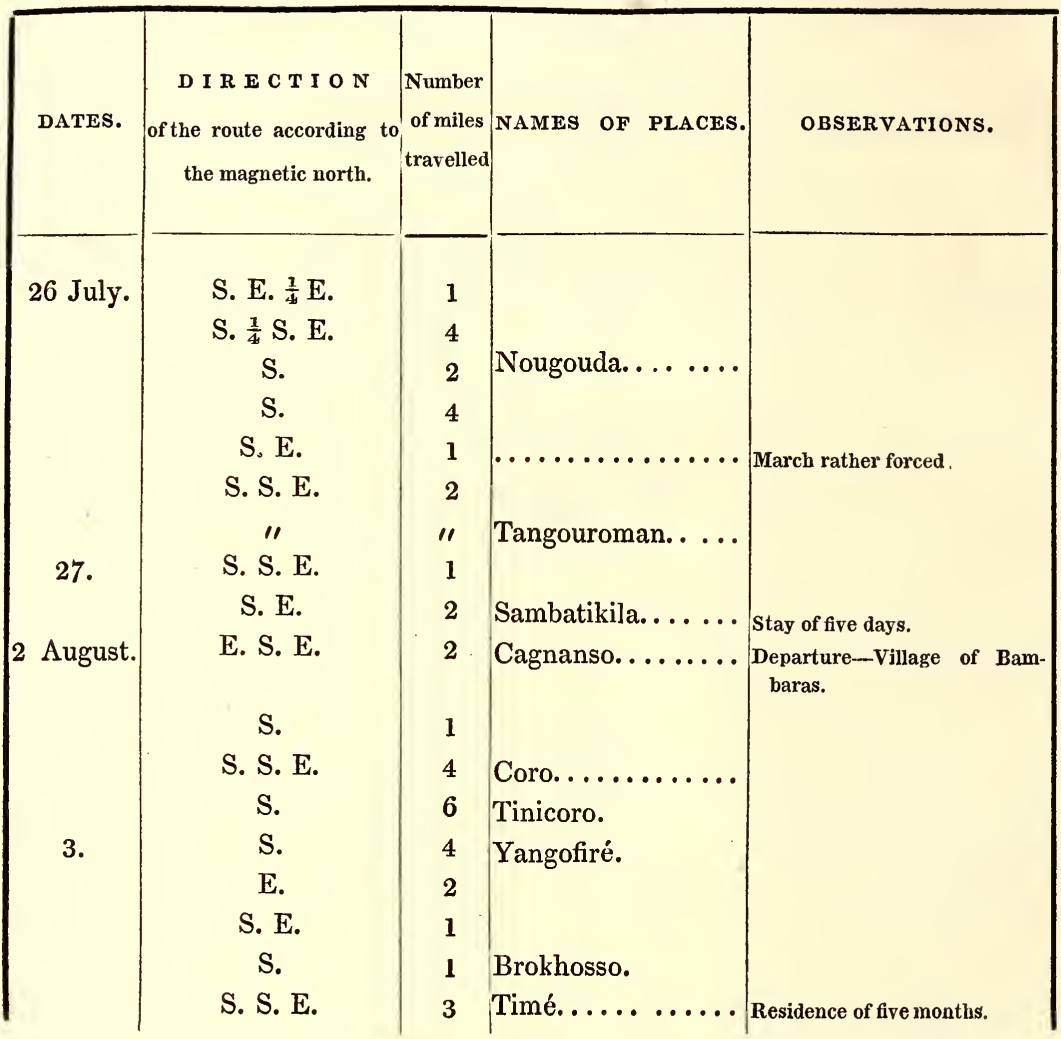




\section{SECONDAART.}

FROM TIMÉ TO TIMBUCTOO.

\begin{tabular}{|c|c|c|c|c|}
\hline DATES. & $\begin{array}{l}\text { D I R E C T I ON } \\
\text { of the route according to } \\
\text { the magnetic north. }\end{array}$ & $\left|\begin{array}{c}\text { Number } \\
\text { of miles } \\
\text { travelled }\end{array}\right|$ & NAMES OF PLACES. & OBSERVATIONS. \\
\hline 1828. & & & & \\
\hline \multirow{3}{*}{9 January } & S. S. E. & 2 & & Departure from Timé \\
\hline & S. S. E. & 2 & & \\
\hline & E. S. E. & 3 & Dsagoé. & \\
\hline \multirow[t]{4}{*}{10.} & S. E. & 3 & Kienba. & \\
\hline & S. E. & 2 & & \\
\hline & $\begin{array}{l}\text { N. } \\
\text { S. E. }\end{array}$ & $\begin{array}{l}1 \\
2\end{array}$ & Zangoériré. & \\
\hline & N. E. & 4 & Dioumiegué. & \\
\hline \multirow[t]{5}{*}{11.} & E. & 2 & & \\
\hline & E. & 2 & & \\
\hline & E. N. E. & 2 & & \\
\hline & N. E. & 1 & & \\
\hline & E. & 1 & Sinisso. & \\
\hline \multirow{2}{*}{12.} & $\begin{array}{l}\text { N. E. } \\
\text { N. E. }\end{array}$ & $\begin{array}{l}4 \\
2\end{array}$ & Salasso. & \\
\hline & N. N. E. & 2 & Loubakho. & \\
\hline \multirow[t]{3}{*}{13.} & N. E. & 4 & & \\
\hline & E. N. E. & 3 & & \\
\hline & N. E. & 5 & Cacorou. & \\
\hline \multirow{2}{*}{14.} & E. & 3 & & \\
\hline & $\begin{array}{l}\text { E. } \\
\text { E. }\end{array}$ & $\begin{array}{l}5 \\
6\end{array}$ & $\begin{array}{l}\text { Tisso-Soman. } \\
\text { Sananso. }\end{array}$ & \\
\hline \multirow[t]{4}{*}{15.} & E. & $\frac{1}{2}$ & & \\
\hline & N. E. & 3 & & \\
\hline & E. $\frac{1}{4}$ N. E. & 4 & & \\
\hline & E. & 3 & Dhio. & \\
\hline 16. & N. N. E. & $\frac{1}{2}$ & & \\
\hline
\end{tabular}


I T I N E R A R Y.

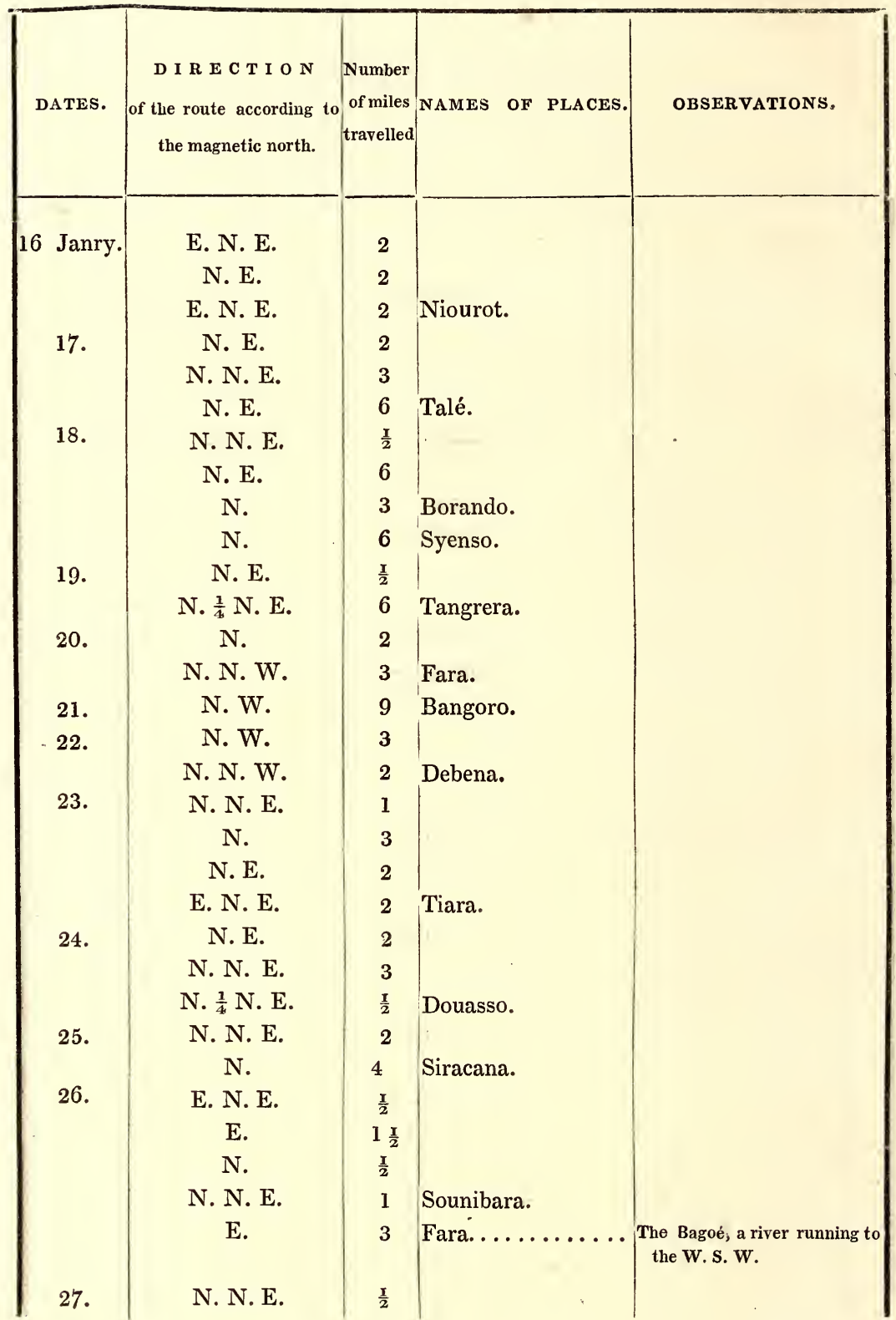




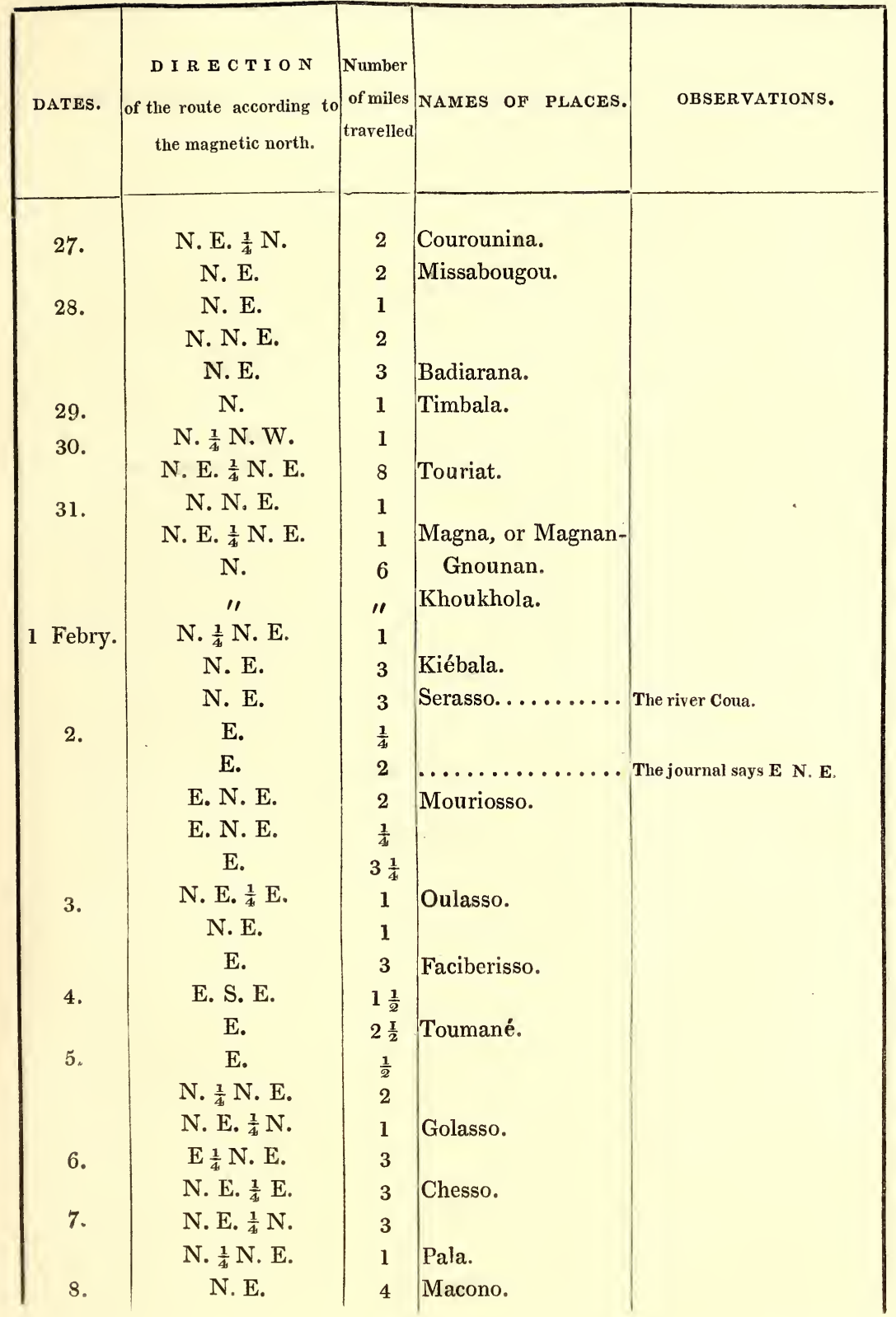


I T I N E R A R Y.

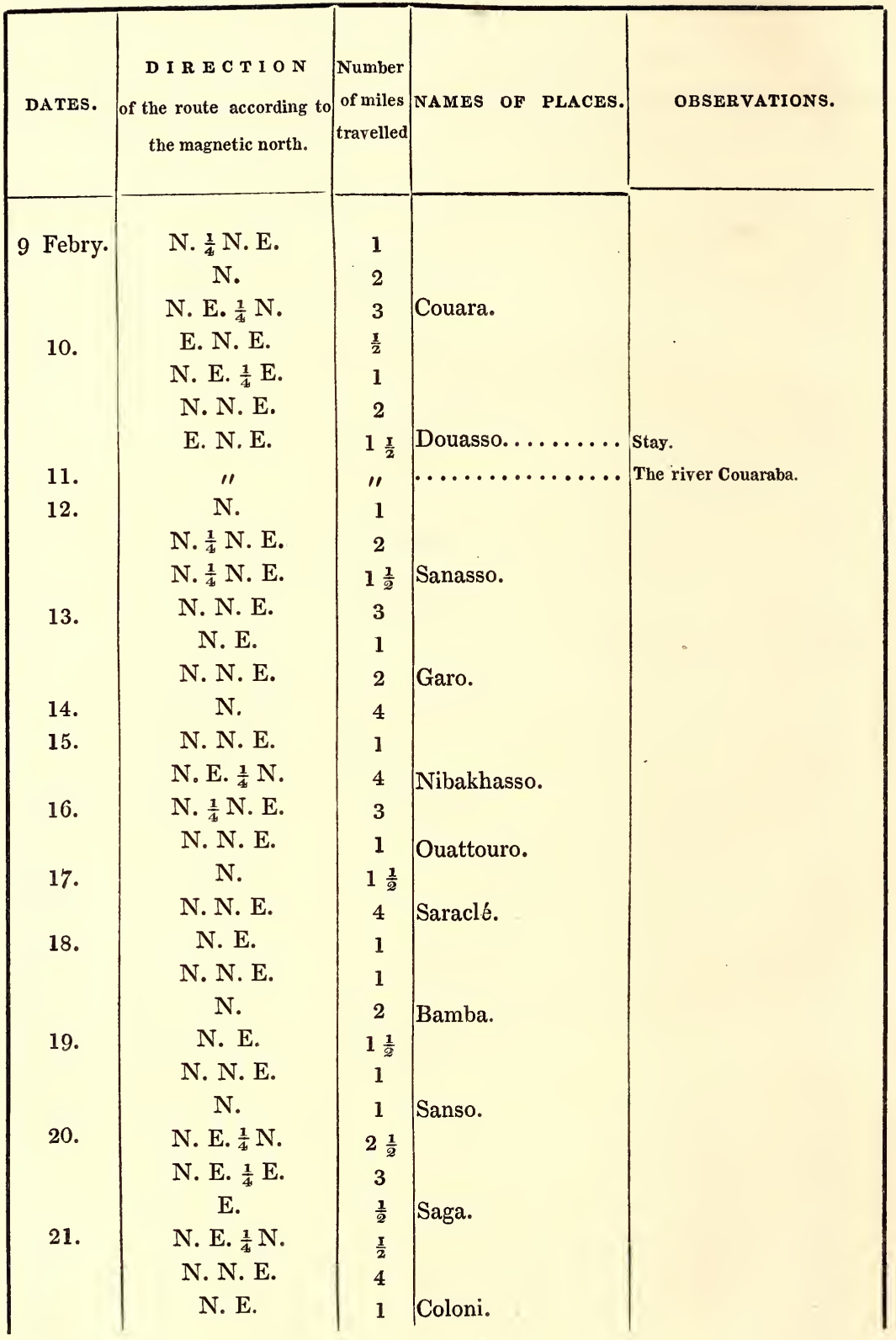


I T I N E R A R Y.

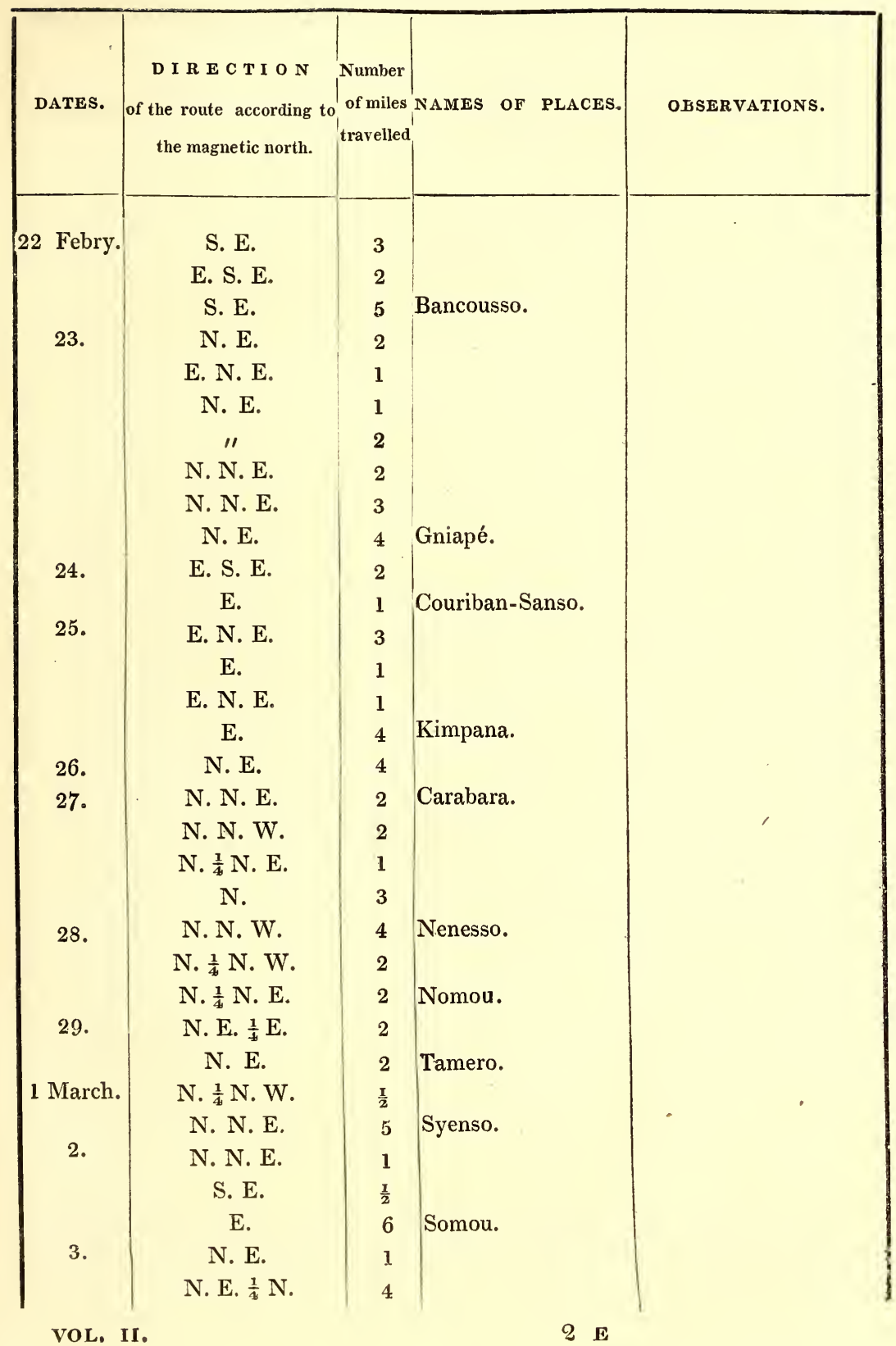




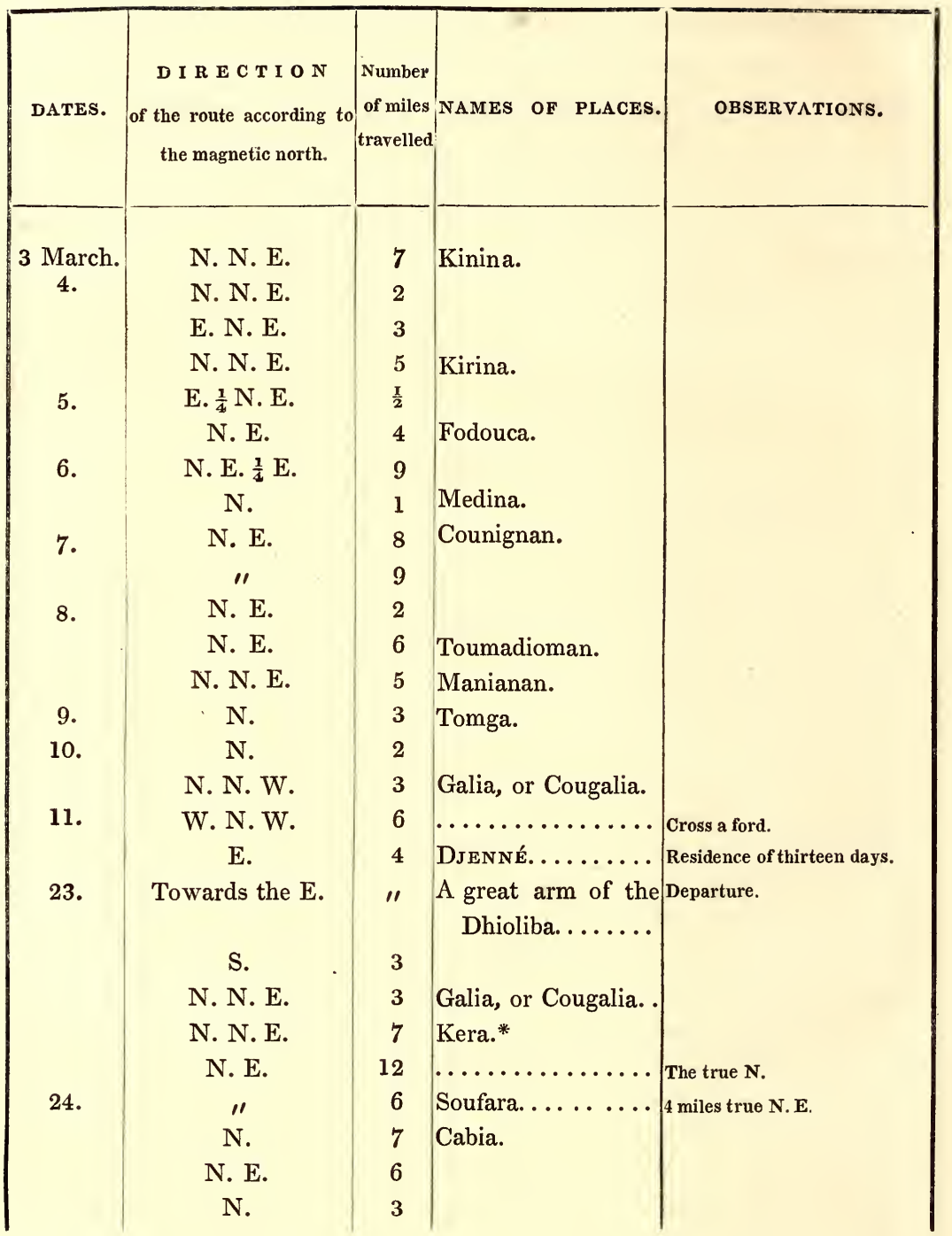

* Beyond Kera, the journeys were noted by hours, which have been here turned into miles at the rate of two miles an hour. The night marches, directed by the true north are summarily mentioned in the column of observations. 
I T I N E R A R Y.

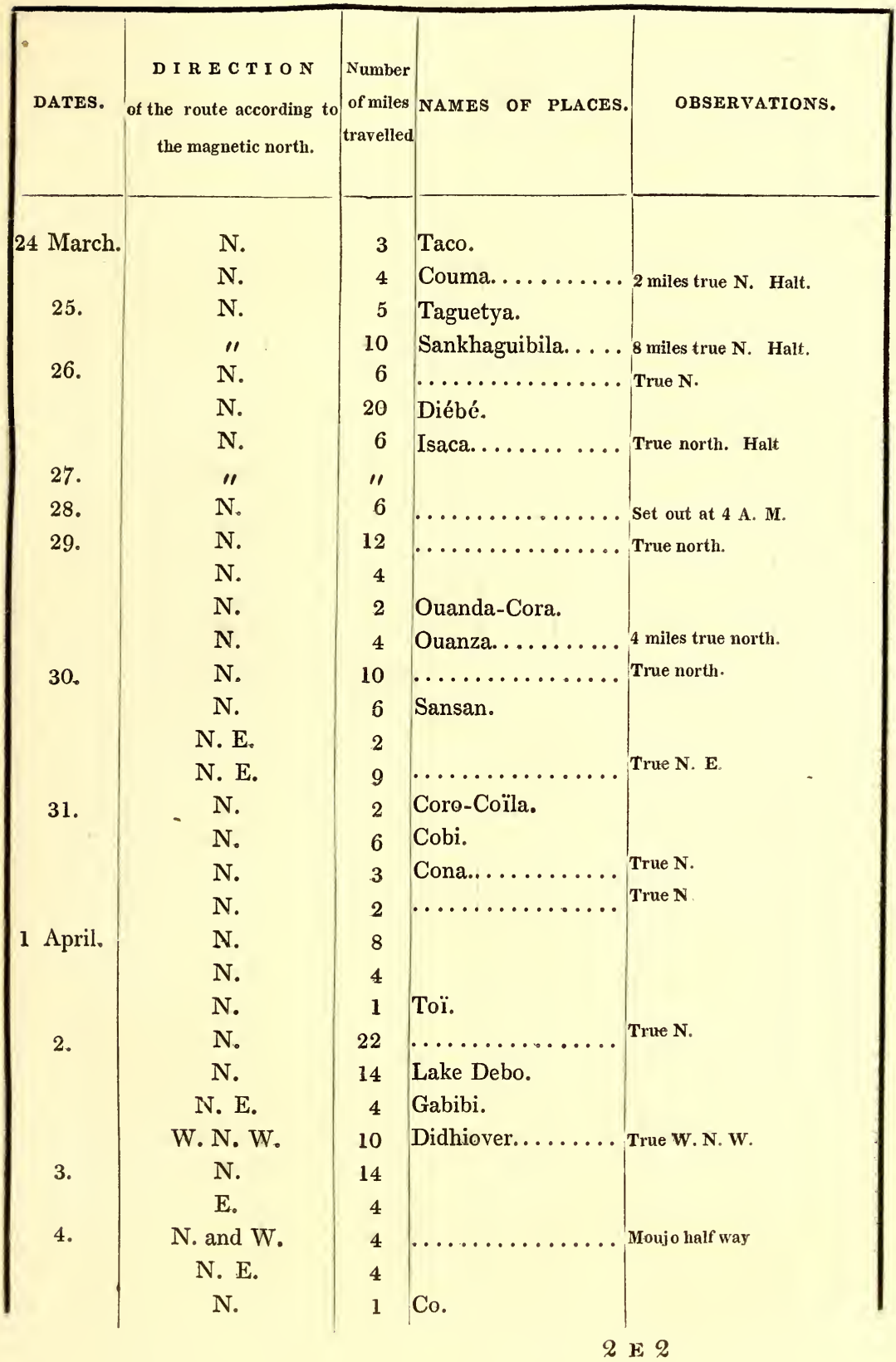




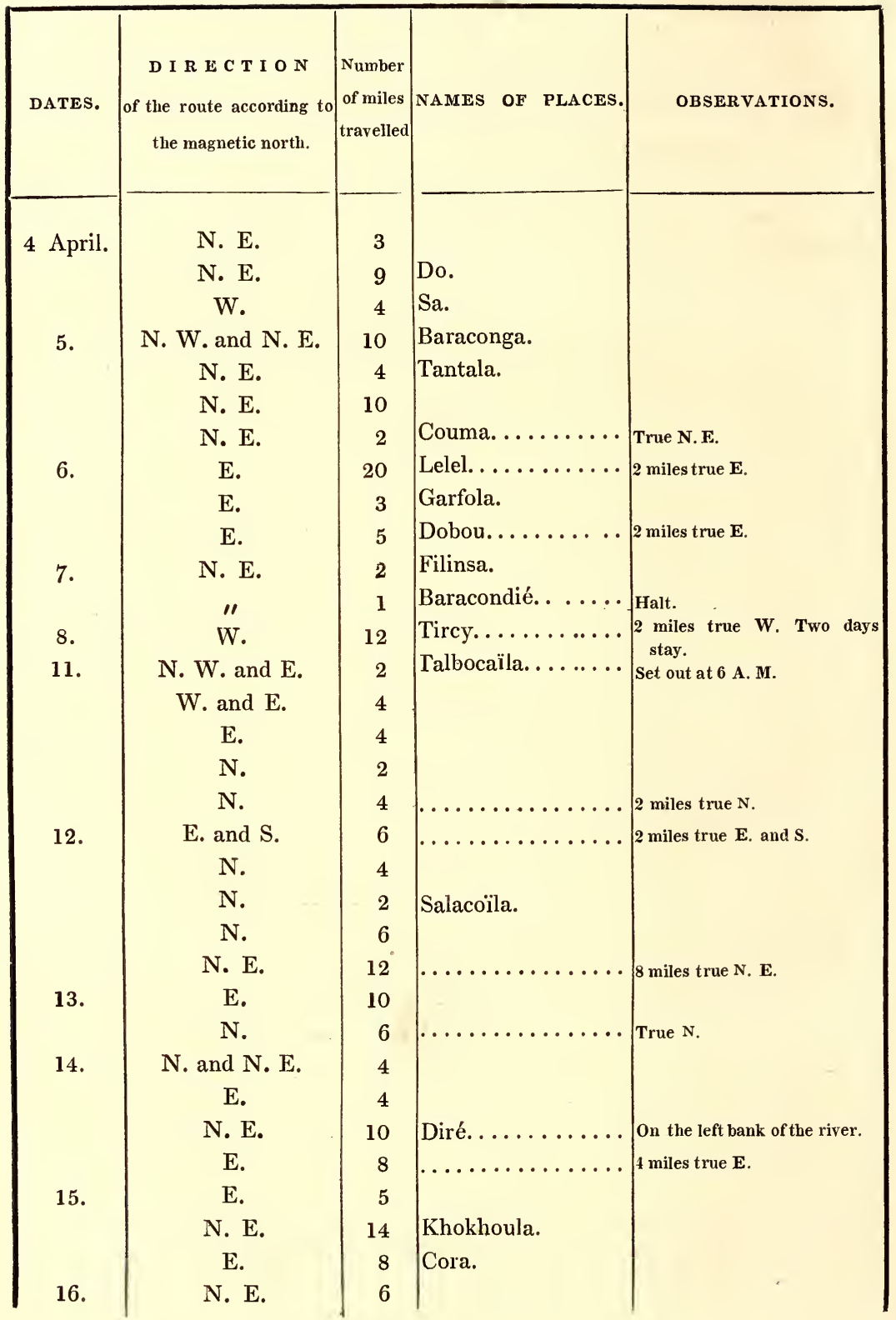




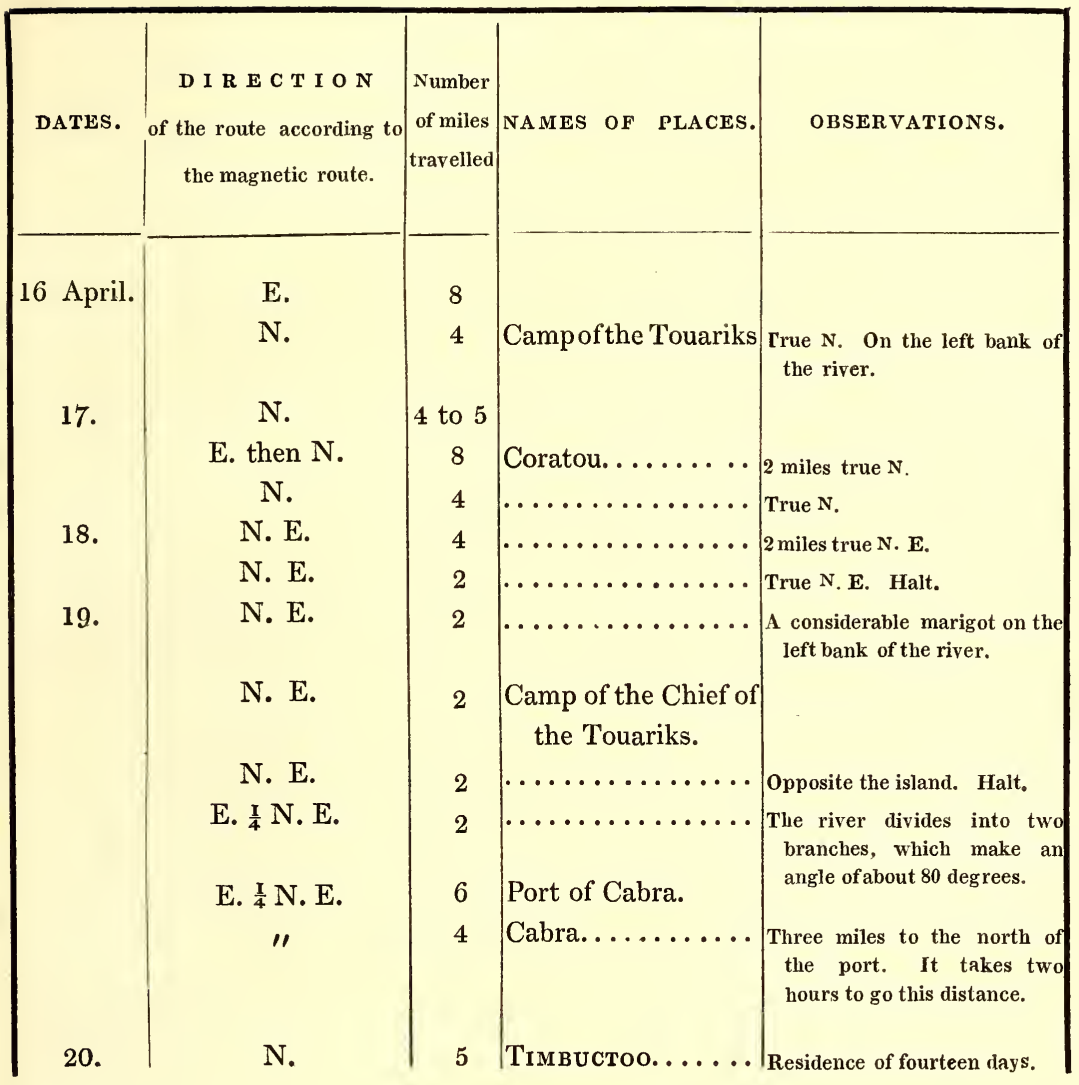


THIR D PART.

FROM TIMBUCTOO TO TANGIER.

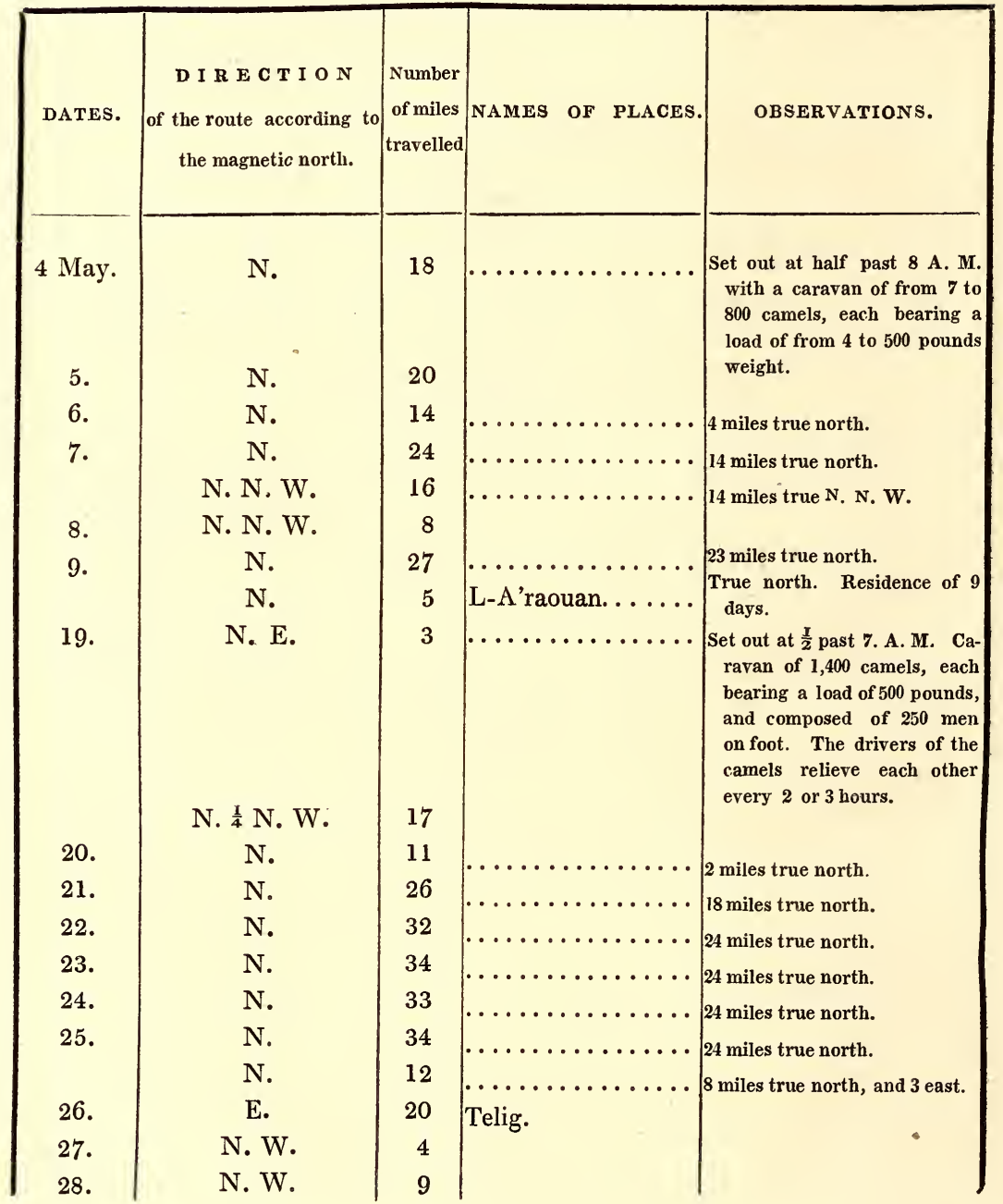




\begin{tabular}{|c|c|c|c|c|}
\hline DATES. & $\begin{array}{c}\text { D I R E C T I O N } \\
\text { of the route according to } \\
\text { the magnetic north. }\end{array}$ & $\begin{array}{c}\text { umber } \\
\text { of miles } \\
\text { travelled }\end{array}$ & NAMES OF PLACES. & OBSERVATIONS. \\
\hline 29. & N. & 6 & & \\
\hline 30. & N. W. & 26 & $\ldots \ldots \ldots \ldots$ & 16 miles true $\mathrm{N} . \mathrm{W}$. \\
\hline 31. & N. W. & 20 & Cramès........... & 8 miles true $\mathrm{N} . \mathrm{W}$. \\
\hline 1 June. & N. & 18 & Trasah........... & Stay. \\
\hline $\begin{array}{l}2 . \\
3 .\end{array}$ & N." W. & $\begin{array}{c}\prime \prime \\
13\end{array}$ & $\ldots \ldots$ & $\begin{array}{l}\text { Set out at } 5 \text { A. M. } 2 \text { miles true } \\
\text { N. W. }\end{array}$ \\
\hline 4. & $\begin{array}{l}\text { N. N. W. } \\
\text { N. N. W. }\end{array}$ & $\begin{array}{r}18 \\
6\end{array}$ & .. & 8 miles true N. N. W. \\
\hline 5. & N. & 18 & Amoul-Gragim.... & 6 miles true north. \\
\hline 6. & $" 1$ & $\prime \prime$ & $\ldots \ldots \ldots \cdots \cdots$ & Halt. \\
\hline 7. & N. N. E. & 15 & $\cdots \cdots \cdots \cdots \cdots \cdots$ & 4 miles true N. N. E. \\
\hline 8. & N. & 16 & $\ldots \ldots \ldots \ldots \ldots$ & 4 miles true north. \\
\hline 9. & N. & 20 & Amoul-Taf. ....... & 10 miles true north. \\
\hline 10. & N. & 10 & $\cdots \ldots \ldots \ldots \ldots$ & 4 miles true north. \\
\hline 11. & N. & 12 & $\ldots \ldots \ldots \ldots \ldots$ & 4 miles true north. \\
\hline 12. & N. & 16 & L-Ekseif. . . . . . . . & 8 miles true north. \\
\hline 13. & $" \prime$ & $\prime \prime$ & $\ldots \ldots \ldots \ldots \ldots \ldots$ & Stay. \\
\hline 14. & N. & 8 & $\cdots$ & 2 miles true north. \\
\hline 15. & N. & 24 & $\ldots \ldots \ldots$ & 14 miles true north. \\
\hline 16. & N. & 33 & $\ldots \ldots \ldots \ldots \ldots \ldots$ & 25 miles true north. \\
\hline 17. & N. & 16 & Marabouty......... & 8 miles true north. \\
\hline 18. & N. N. E. & 6 & & \\
\hline 19. & N. & 22 & $\cdots \cdots$ & 10 miles true north. \\
\hline 20. & N. & 18 & $\cdots \cdots$ & 10 miles true north. \\
\hline 21. & N. & 18 & El-Guedea. . . . . . . & 12 miles true north. \\
\hline 22. & N. & 10 & $\ldots \ldots \ldots \ldots \ldots$ & 2 miles true north. \\
\hline 23. & $\begin{array}{l}\text { N. } \\
\text { N. N. W. }\end{array}$ & $\begin{array}{r}22 \\
6\end{array}$ & $\left(\begin{array}{c}\cdots \ldots \ldots \ldots \ldots \\
\ldots \ldots \ldots \ldots \ldots \ldots\end{array}\right.$ & $\begin{array}{l}16 \text { miles true north. } \\
\text { True N. N W. }\end{array}$ \\
\hline 24. & $\begin{array}{l}\text { N. N. W. } \\
\text { N. N. W. }\end{array}$ & $\begin{array}{r}28 \\
4\end{array}$ & $\ldots \ldots \ldots \ldots \ldots$ & 18 miles true N. N. W. \\
\hline 25. & $\begin{array}{l}\text { N. } \\
\text { N. }\end{array}$ & $\begin{array}{r}16 \\
4\end{array}$ & 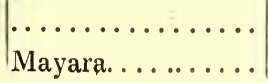 & $\begin{array}{l}\text { True north. Halt. } \\
\text { True north. Halt. }\end{array}$ \\
\hline
\end{tabular}




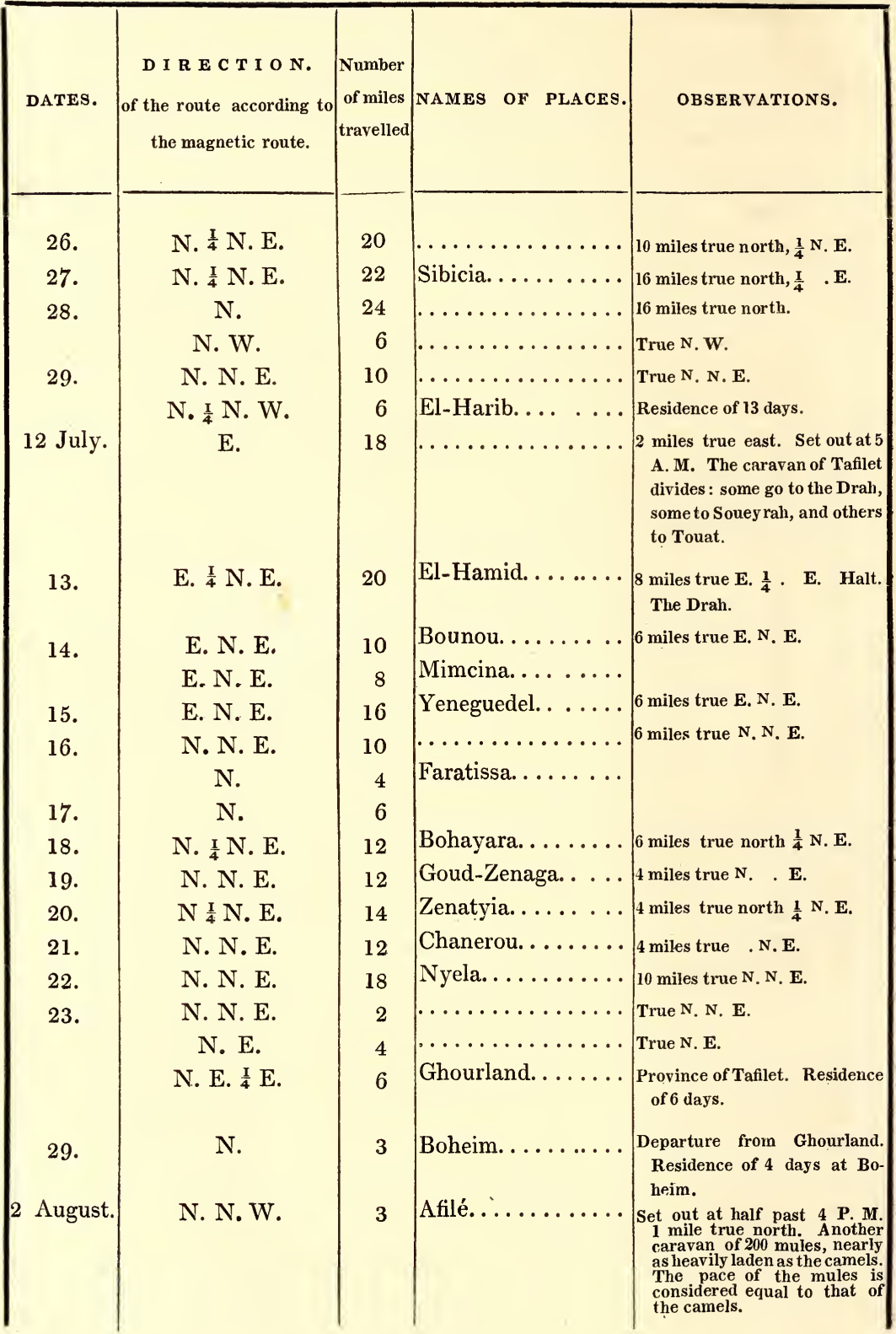




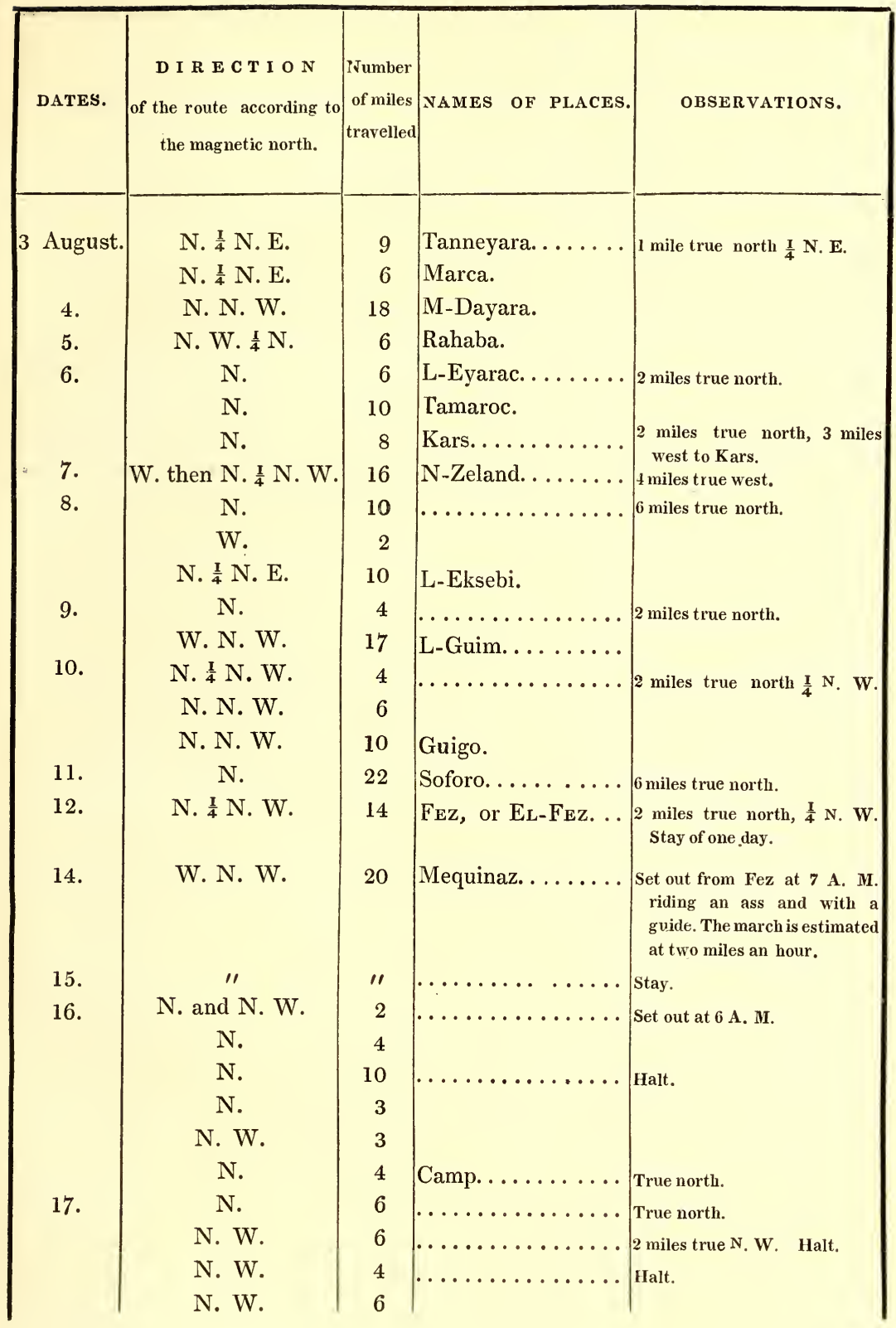




\begin{tabular}{|c|c|c|c|c|}
\hline DATES. & $\begin{array}{c}\text { D I R E C T I O N } \\
\text { of the route according to } \\
\text { the magnetic north. }\end{array}$ & $\begin{array}{l}\text { Number } \\
\text { of miles } \\
\text { travelled }\end{array}$ & NAMES OF PLACES. & OBSERVATIONS. \\
\hline $\begin{array}{l}17 \text { Aug. } \\
18 . \\
2 \text { Sept. } \\
7 .\end{array}$ & $\begin{array}{l}\text { W. S. W. } \\
\text { S. W. } \\
\text { S. W. } \\
\text { "l } \\
\text { "। }\end{array}$ & $\begin{array}{r}5 \\
10 \\
7 \\
11\end{array}$ & 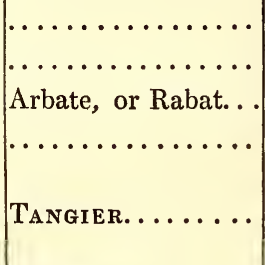 & $\begin{array}{l}\text { Halt. } \\
6 \text { miles true S. W. Halt. } \\
\text { Residence of } 15 \text { days. } \\
\text { Departure for Tangier with a } \\
\text { guide and an ass. Passed } \\
\text { through Larache. } \\
\text { Arrived at night-fall, after five } \\
\text { days journey on the sea shore. }\end{array}$ \\
\hline
\end{tabular}




\section{H A P T E R I V.}

\section{EXPLANATION OF THE PLATES,}

Followed by Notes on the Fragments of Plants brought over by M. Caillié, on some natural productions of the countries he has traversed, and on several points of geography.

P1. I. Portrait of the Traveller.

Pl. II. A woman of Timbuctoo.

Pl. III. M. Caillié meditating upon the Koran and taking his notes.

Pl. IV. Plan of the great mosque of Timbuctoo, and a view of it taken from the E. N. E.*

Fig. 1. Plan of the mosque on a scale of a thousandth.

$a$. Niche or recess for the ceremonies of religious worship; it is formed in a very ancient wall. See pl. V. fig. 1.

$b$. The great tower.

* This is the mosque called in the description the Western Mosque, and which is situated to the W. S. W. of the town. 
c. Niche, having the same destination as that marked $a$.

d. Turrets.

$e, e, e$. Buttresses.

$f$. Principal door of the mosque.

$g, g, g$. Small doors of the mosque.

$h, h$. Limit of the examined parts.

$i, i, i$. Pillars decorated with a particular kind of ornament. See pl. V. fig. 2.

$k, k$. Interior façade, with an ornament en chevron, represented in pl. V. fig. 3.

l. Very ancient part of the mosque; the arcades supported by these pillars are smaller than the new arcades on the east.

$m$. Traces of the ancient inclosure.

Fig. 2. View of the mosque taken from the E. N. E., on a double scale.

Pl. V. 1, 2, 3. Details of the great mosque of Timbuctoo. 4, 5. Plan and front of the house of Sidi-Abdallah-Chebir, in which M. Caillie resided.

Fig. 1. A wall forming part of the ancient mosque. See the point $a$, pl. IV. fig. 1 .

Fig. 2. Interior decorations, attached to the pillars. See the points $i, i, i, \mathrm{pl}$. IV.

Fig. 3. Ornament of the wall. See points $k, k$, pl. IV.

Fig. 4. Plan of Sidi-Abdallah-Chebir's house.

a. Principal entrance.

$b$. Situation of the staircase. 
$c, c, c$. Warehouses.

d. First court.

$e$. Second court.

f. Stables.

$g$. Kitchen of the slaves.

$h$. Lodging of the slaves.

$i$. Privies.

Fig. 5. The front elevation of the house. Over the door is a chamber, the window of which is closed by a wooden lattice, as in the towns of the Levant; and above are some earthen vessels for the use of the pigeons. Upon the wall are seen small gutters of earthenware, to carry off the water.

Pl. VI. View of part of the town of Timbuctoo, taken from the summit of a hill to the E. N. E.

1. The great mosque, or western mosque.

2. East, or east north east mosque.

3. Third mosque.

4. House of Osman, the chief who governs at Timbuctoo.

5. House of Sidi-Abdallah-Chebir.

6. The market.

i. Caravan coming from the Tafilet.

Pl. VII. Itinerary map, and general map of the travels. The scale of the first map is of one to a million; that of the other is one-eight millionth, or the eighth part of the former. It is to be regretted that these scales could 
not be enlarged, and that, consequently the details of the routes could not be more clearly laid down. The first chapter of the supplement will spare me the necessity of explaining this plate more at length. 


\section{PLANTS.}

In addition to the explanation of the engravings, I will say a few words respecting several fragments of plants collected in the environs of Kakondy (Rio-Nuñez), which botanists have considered either too ill-preserved or too incomplete for engraving. M. Caillié made sketches of some which appeared equally unfit to be committed to the graver.

1. Native name. SAULÉ-Kémé. The blossom has ten stamina, two of them large and of a deep yellow, and three smaller supported by a very fine and twisted fibre; the flower deserves attention for its beauty; it appears fit to adorn a garden; it emits a sweet and agreeable odour; its colour is a light yellow; the pistil is green. The shrub which produces it, grows on a bush to the height of eight or ten feet. It has not been seen in fruit.

The sketch traced by M. Caillie, and the little sample which he gathered, shew the nature of the foliage; it is of the leguminous kind: the leaves are oval, rounded; the flower in bunches, the pedicle furnished with stipulæ, the anthers bifid, the style long and filiform.

According to the learned M. Kunth, who has obliginglyexamined this and the two following specimens, this 
plant is no other than acassi a Cassia fistula, of a species of which, it is well known, there are very lofty trees.

2. Name unknown. The newly opened blossom is white; it turns afterwards yellow: the perfume it exhales is extremely agreeable. The shrub is nine or ten feet high; I at first took this flower for that of an American gourd. (M. Cailliés notes.)

The leaf is lanceolated and pointed; the corolla is large, monopetalous, funnel-shaped, with a long tube, having seven great divisions, oval and very deep; the calyx appears to have eight divisions; the fruit is ovoï ; the stalk is furnished with long blunt thorns This plant appears to belong to the rubia family.

M. Kunth considers it as a species resembling the gardenia thunbergia, but differing in having rough and smaller leaves.

3. Name unknown.-The blossoms and leaves are hairy; the petals blue; the plant is herbaceous. It is with its root that the Landamas make the purgative drink which they call jinjindhi; this root resembles the small cassava. (M. Cailliés notes.)

The fruit and stalk are also hairy. The leaves are pointed oval, of a beautiful green, marked with four longitudinal borders, and covered on one side with flat short and very glossy hairs. The flowers have 
five petals, the form of which is oval and pointed; the hairs of the calyx are long. This plant belongs to the melastomaa. This genus is known to be very numerous in America; but it had not previously been found in Africa.

M. Kunth considers it as a species of rhexia, differing from those of Africa, published by M. de Beauvoir; but it is too incomplete to admit of its species being determined, 
MISCELLANEOUS NOTES.

A. Hibiscus.-In the environs of Djenné, the traveller saw an hibiscus, of which cords are made as with hemp ; these cords serve for the construction of the canoes. At the Senegal there is also an hibiscus fit for this operation. It was found, I believe, on the banks of the Gambia, where it is known by the name of hibiscus cannabinus. In the construction of canoes, two trunks of trees are united and firmly bound together with the cords in question.

B. Cotton plant.-M. Caillié observed, on the road from Djenné, a species of cotton plant which he believes to be annual. This statement has been doubted : yet in Egypt there is also an herbaceous cotton-plant, and there is no reason against the admission of the fact.

C. The Bombax is a tree known in Senegambia; its fruit produces a very fine and glossy silk, capable of being manufactured. M. de Beaufort sent over samples of it. The narrative shews that this beautiful tree is also very common south of Senegambia.

D. Bark, yielding a beautiful red dye. M. Caillié has not made us acquainted with the nature of the tree 
that bears this bark, which on being merely washed yields a red colour. But the discovery would be easily made, since the tree grows not far from the French possessions.

E. Mimosa.-M. Caillié saw several large species of mimosas; it is a subject of regret that he has not described each. One of the most spreading is the nédé, a beautiful tree, with a globular flower of a red colour borne on a very long pedicle; the foliage is very delicate. The natives eat the pulp by which the seed is surrounded.

F. Balanites.-This tree is one of the most common along the whole of M. Caillié's route, from Kakondy to Djenné. The inhabitants extract an oil from it.

The Balanites Agyptiaca. (Delile)* is not the only tree common to this country and Egypt; the same may be said of many other natural productions, and of plants and animals in general. This remark has been frequently made since the publication of the travels of the French in Egypt, and the dis coveries in natural history made in Senegambia. The similarity of the two countries in certain respects, a great river annually overflowing, a very high temperature, the vicinity of the desert, and other circumstan-

- My learned friend M. Delile, author of the Flore d'Egypte, considers this tree as the persea of the ancients; but this opinion is disputed. 
ces seem, at the first glance, sufficiently to explain this identity.

But I do not believe that in this case the difference of the latitude has been observed. The mean parallel of Egypt is about $27^{\circ} \frac{1}{2}$; that of Senegambia 13; difference $14^{\circ} \frac{1}{2}$. If the height of the temperature is important, as it undoubtedly is, amongst the causes which encourage to a certain extent some species of vegetables and animals, it must be concluded that Egypt is the warmest region of northern Africa in proportion to its latitude. The mean temperature of Egypt is, actually higher than that of the Senegal: this was far from being suspected prior to the observations of the Egyptian Institute; and Baron Humboldt did not introduce his Memoir on the isothermal lines till after having long retained doubts, which the tables of Messis. Nouet and Coutelle dispelled. 'Thus, the isothermal line of Egypt would make a large angle with the equator. Mount Atlas is too far distant to explain the fact; the mountains of Senegambia are not sufficiently elevated; we are, therefore, led to seek the cause in the vicinity of the Sahara, the vast radiation of which must incessantly attract the lower strata of a warmer atmosphere, such as that of Senegal and of the more remote districts, on account of their nearly juxta-equatorial position : so that the mean temperature of Senegambia would, but for this cause, be much higher than it is, and far higher than that of Egypt. 
These considerations leave room to regret that we have no meteorological observations made at Timbuctoo, not only on the thermometer and barometer, but also upon the state of the heavens and the prevailing winds; such no doubt exist among the papers of Major Laing, as may be concluded from the terms of his letter, written from that city, the 21 st of September, 1826*。

\section{G. Doum.-The Doum Palm-tree, (corypha thebaica} Decire), belongs to Upper Egypt. It is remarkable that a tree of this species exists in the city of Timbuctoo; it is the only one, the other trees of the place being all balanites.

H. Lotus (nymphoea.).-This again is a plant common to Egypt. In the latter country the root only is now eaten; but the negroes, like the ancient Egyptians, use both the root and the fruit.

I. Thistle of the Desert.-This, according to the description given of it by M. Caillié, appears to be the hedysarum alhagi, (LinN.) a well known plant, and which constitutes the provender of the famished camels; in spite of its rough prickles, they eat it with delight in traversing the desert.

* See “ Rćflexions sur l'état des Connoissances relatives au Dhioliba," page 25. 
K. Butter-tree, cé, ché or shea.-Mungo Park describes this tree under the latter name of shea and sheatoulou. M. Caillié met with it all over Senegambia as far as Djenné. The nédé and the ché are the most common trees. Samples of this vegetable butter were sent to France by M. de Beaufort, and M. Vauquelin was commissioned by the Academy of Sciences, to analyse it. This tree would be a most valuable acquisition in our colonies.

We owe to M. Caillié the knowledge of a second vegetable butter called taman-toulou, preferable, he thinks, to the former. It is derived from a second tree, which appears to be different. Its name, or that of the fruit, is taman. The word toulou means butter or a fat substance in Mandingo. The oil palm-tree renders nearly the same service to the inhabitants. as the foregoing.

L. Colat-nut.-The fruit known to Europeans by this name is very common in the interior of Africa, as well as on the banks of the Rio-Nunez. The Mandingo name is ourou. According to M. Caillie this is the same fruit with that called gour by Major Denham: but, in reading the work entitled Narrative of Travels and Discoveries in Northern and Central Africa, \&c., London, 1826, I found this name neither in the description, nor in the annotations added to this important work by the learned botanist, Robert Brown. 
N.B. I pass over in silence several vegetables obtained by M. Caillié, and mentioned in the journal of the travels, having nothing to add to what he has reported, and regretting that his description is insufficient to shew their nature : for example, that of the caura, which our traveller compares to a plumtree. It will be seen by the narrative that orangetrees are indigenous in the northern part of Senegambia*.

M. Carrier Oxen. In the early part of his journal, M. Caillié mentions, by name only, this species of oxen. It is a question worthy of the attention of future travellers, both as regards commerce and expeditions of discovery.

N. Elephants and Lions. Several persons have testified surprise that M. Caillié, during so long a journey, met with neither lions, elephants, giraffes, nor any wild beast. I am far from disputing the testimony of those travellers, who affirm that such have been seen in inhabited places; but, it is certain, that any one meeting with such animals on his way cannot have any motive for passing over the circumstance in silence, and that all travellers are rather partial to

* M. Caillié has brought away some seeds and fragments of gramineous and leguminous plants, collected between Timé and Djenné, and on the banks of the Dhioliba, now deposited at the vice-consulate of Tangier, with some white stone from the wells of El-Araouan, some minerals, and the plummet of which I have spoken. 
adorning their narratives with encounters of this kind. It may, therefore, be legitimately inferred that elephants and lions are more scarce in those regions than the narratives and descriptions would lead us to believe. M. Caillié, however, in one or two passages, mentions the traces of elephants' feet; but no tragic adventures befel him, (or any individual of the numerous caravans which he accompanied for the space of a year,) by encounters with these monsters, with wild beasts, or with any other dangerous animals. The same may be said of crocodiles, which were supposed to abound in the Dhioliba. Scarcely was he once incommoded, and that by the neighbourhood of an enormous serpent, during his whole journey across the great desert.

O. Tanning. The preparation of leather is frequently mentioned in the Journal. It is known that the Africans, and the Moors particularly, are very successful in this operation. Some persons have thought that desiccation is the means they principally use; but this seems improbable, because both in Nubia and Egypt the true process of tanning is in use, and is quite as good as ours, though shorter. The natives are also skilful in working the leather; they cut and embroider it with great success.

P. Beer. M. Caillié sometimes speaks of the use of beer; but he has neglected to tell us how and with what it is made. Is it the beverage which in Egypt 
is called hachich? 'The Egyptians prepare this with hemp-seed. It is an inebriating liquor, of which the common people drink to excess, notwithstanding the rules of Mahometan abstinence.

Q. The Tankisso. We read at page 204, in the first volume of this work, that, according to the Mandingoes, this river issues from the Bafing, and flows into the Dhioliba. It is difficult, if not impossible, to admit this representation of the Mandingoes: it must be understood, I think, that the Tankisso has its source in the same mountain with the Bafing; otherwise the bason of the Senegambia would communicate with that of Nigritia or the Soudan.

R. The route from the Fouta-Toro to Mecca. The author was told (see vol. I page 259) that the pilgrims of the Fouta travelled by the Bondou, the Baleya, Kankan, Sambatikila, and Djenné, instead of by Kaarta and Sego. The former road, however, is much the longer. I believe that the real motive of these travellers is to trade in the gold of Bouré, in passing through Kankan; but why go still farther to the south, by Sambatikila? I do not see the reason.

S. The Milo. It is said, vol. 1 page 280 , that the Milo flows N. E. The first part of the course of this river is nearly N.E. by the compass; but it after- 
wards inclines to the north and west, to fall into the Dhioliba.

T. Kong or Koung. The country of this name, being situated between the magnetic S. S. E. and S. $\frac{1}{4}$ S. E. from the village of Douasso, (vol. I p. 41\%) lies to the true south of that village. Our traveller was informed by a Kong-man, that the journey required a month and a half. Part of this journey is through a mountainous country. The position, therefore, of Kong cannot be far from the seventh degree north, or its longitude far from that of Douasso, $7^{\circ} 45^{\prime}$ west.

U. Direction of the river near Djenne. The Journal states, page 444 , vol. I, that the island is formed by an arm of the western branch, which comes from the west-north-west. The island of Djenné, according to the author, is about twelve or fifteen miles in circumference; but he admits that he did not go round it, and it appears to be much larger.

V. Distance from Djenné to Isaca. The text states it at a day and a half's journey; but even in a straight line it proves to be more than three and a half. The traveller has reckoned it at four days by water; so that this passage requires correction.

X. Bousbeyah. The word Bousbehey in the text, (pages 58 and 101, vol. II) must be thus written, 
according to the orthography of the foregoing Arabic list.

There is a contradiction between pages 58 and 101: this place must necessarily be at more than two days' distance from el-Araouan, if it is only two days from Timbuctoo; I have adopted this latter distance.

Y. Oualet. The town of this name is placed, according to the Journal, (vol. I page 301) ten days distance from el-A'raouan, W. N. W.; but it is farther from Sego than stated in the text (the same page), which is fifteen days south : the interval is nearly double. This confirms the conjecture I have raised, viz: 1st, that there are two places of this name; 2nd, that this is different from the one placed in Mungo Park's first map north of Sego, but under the parallel of Lake Dibbie; and the other N. W. of Sego, a little north of Timbuctoo. This is not the place for discussing the situation of Oualet and comparing it with the Gualata of Leo Africanus, which he states* to be three hundred miles south of Nun, five hundred north of Tumbut, and a hundred from the ocean. It may suffice to say, that a single point cannot possibly fulfil these different conditions.

I think, however, that there is a very easy solution * Descript. Afric. \&c. page 429, Tigur. 1559. 
of the difficulty. Park and his editors having fallen into the error of imagining Timbuctoo much more south than it really is, have made a corresponding change in the position of Oualet : in short, the place noticed by M. Caillié is situated relatively to Timbuctoo, very nearly as it is placed in the second map of the English traveller, and both must be carried much farther north than they there appear.

It would be easy to extend these geographical remarks by a number of scientific deductions, more or less interesting to some readers; but it is time to bring this volume to a close, and in conclusion to claim the public indulgence in behalf of a work hastily drawn up, and whose only substantial recommendation to attention is the importance of its subject, and the influence which the discovery itself must sooner or later exercise over future enterprizes.*

* Consult the interesting work entitled Naufrage du brig français la Sophie, par M. Charles Cochelet, (Paris, 1821, in 8vo) where the author affirms that Sidi-Hamet did not visit Timbuctoo, and raises doubts upon the travels of Adams. (Tom. 2, chap. XV.) 


\section{CHAPTER V.}

DOCUMENTS AND MISCELLANEOUS PAPERS.

We shall place at the close of our remarks several papers which the reader will perhaps be well pleased to peruse. In 1824, the Geographical Society published a programme of a premium to be decreed to the first French, or foreign, traveller who should arrive at Timbuctoo by the way of Senegambia. It is known that this programme was distributed throughout Europe and in Africa, and that it powerfully influenced the efforts or the projects of many travellers, and especially the resolution adopted by M. Caillié. We shall give this programme as published; and afterwards, the report made to the same Society by the committee which it appointed four years afterwards to judge of the merit of the discoveries made by the French traveller. These two papers will be followed by extracts from the correspondence relative to his return to Europe. 
SOCIE'TY OF GEOGRAPHY 1824.

Premium for a Journey to Timbuctoo and the Interior of Africa.

The fortunate attempt of the English travellers who penetrated into Central Africa in 1823 has lately attracted the attention of Europe towards the interior of that continent, which now divides public curiosity equally with the polar regions, the centre of Asia, and the new countries of Australia. It was natural that the Society of Geography should direct its attention to this quarter also, pointing out as preferable the route already attempted by Mungo Park, and which touches upon the French establishments in the Senegal ; with it therefore originated the idea of a subscription for the encouragement of travels to Timbuctoo. It proposes 10 offer a premium to any traveller who shall be fortunate enough to surmount all the perils incident to this enterprise, and who shall at the same time obtain some certain information and positive results respecting the geography, the productions, and the commerce of that country and the regions lying to the east of it. France was the first country of Europe which formed permanent establishments on the Senegal, and her honour is interested in assisting those travellers who seek to penetrate into the interior of Africa, by the route approaching nearest to her settlements. Such an enterprise, if successful would not be without profit to our commercial industry; and, considering it with respect to the sciences, what an inexhaustible source of discovery would it not open to 
natural history, natural philosophy, climatology, physical geography, and mathematics! What an immense field for a knowledge of the races of mankind, for the history of the civilization of nations, for that of their language, of their manners, and of their religious opinions !

The intention of the donors is not precisely to propose a prize for competition; the lure of a sum of money could not be offered for an attempt which might be attended with the loss of life : but they hold in reserve a just and honourable indemnity for him who shall happily overcome all the obstacles, to which so many others have, up to the present time, succumbed.

As the judge and dispenser of this recompense, the Society of Geography will duly appreciate the merit, the courage, and the devotedness, of travellers, as well as the real services they may have rendered to science. It does not expect from a single individual all the results which would require the concurrence of several observers and many years peaceable residence in the country ; but it demands precise information, such as may be expected from a man provided with instruments, and who is no stranger either to natural or mathematical science. At the present moment several travellers, both French and English, are proceeding towards the banks of the Dhioliba, and the Society has reason to hope that the encouragements held out by it will not prove unprofitable.

At the meeting of the Central Committee of the 3rd 
of December 1824, an anonymous donor, a member of the Society, presented a thousand francs, to be offered as a reward to the first traveller who shall have penetrated as far as Timbuctoo by the way of the Senegal, and fulfilled the following conditions pointed out in the minutes of the said meeting: "To furnish 1st., some positive and exact observations upon the situation of this city, the course of the rivers which run in the neighbourhood, and the commerce of which it is the centre; 2ndly, the most satisfactory and precise information respecting the country comprised between Timbuctoo and the lake Tsad, as well as concerning the direction and the height of the mountains which form the bason of the Soudan." Immediately upon being made acquainted with this offer, Count Orloff, Senator of Russia, consented that the donation of a thousand francs, which he had made of the sum at the general meeting of the 26th of November 1824, for the encouragement of geographical discoveries, should be applied to the same purpose.

On being informed of the object of these donations, his Excellency the Count Chabrol de Crousol subscribed, on the 15th of December following, the sum of two thousand francs, in the name of the Ministry of the Marine, for the same undertaking; by his letter, dated the 22nd of January last, his Excellency the Baron de Damas subscribed also, in the name of the Ministry for Foreign Affairs, the sum of two thousand francs; and by another letter dated the 19th of March his Excellency the Count de Corbière subscribed, in the name of the Ministry of the 
Interior the sum of one thousand francs. Many other subscriptions have been received or announced for the same object.

The Society of Geography, charged by the donors to decree the reward, and wishing to take a direct part in the encouragement of so important a discovery, has resolved moreover to offer a gold medal of the value of two thousand francs to the traveller who, independently of the conditions already declared, shall have satisfied, as far as possible those which are explained below.

The Society demands a manuscript narrative, with a geographical map, founded upon celestial observations. The author shall endeavour to study the country with reference to the principal points of its physical geography. He shall observe the nature of the soil, the depth of the wells, their temperature and that of their sources, the width and the rapidity of the rivers, the colour and the clearness of their waters, and the productions of the countries which they irrigate. He shall make remarks upon the climate, and determine in various places, if possible, the declination and inclination of the magnetic needle. He shall strive to observe the different breeds of animals, and to make some collections in natural history, such as fossils, shells, and plants.

When he shall have arrived at Timbuctoo, if he cannot go further, he shall acquaint himself with the routes leading to Kachnah, Haoussa, Bournou, and lake VOL. II.

2 G 
Tsaad, to Walet, Tischit; and even the coast of Guinea. He shall collect the most accurate itineraries he can procure, and consult the best informed inhabitants upon that part of the course of the Dhioliba which he cannot see for himself.

In observing the people, he shall take care to examine their manners, ceremonies, customs, weapons, laws, religion, food, diseases, the colour of their skin, the form of their face, the nature of their hair, and also the different articles of their commerce. It is desirable that he should form vocabularies of their idioms, compared with the French language; finally, that he should make drawings of the details of their habitations, and take plans of the towns wherever it is possible to do so. 
REPORT OF THE SPECIAL COMMITTEE APPOINTED TO INVESTIGATE M. CAILLIÉ'S TRAVELS TO TIMBUCTOO AND IN THE IN'TERIOR OF AFRICA.

\section{Gentlemen,}

You have appointed a committee, consisting of Messrs. Eyriés, Cadet de Metz, Amédée Jaubert, Larenaudière, Baron Roger, and myself, to ascertain the facts resulting from the travels of M. Auguste Caillié in the interior of Africa. This committee has assembled, and I am charged by it to make you the following report. Our first care was to satisfy ourselves on the points of the traveller's departure, the routes which he had followed, and the countries and places which he had visited. Interrogated on these various questions, and on all the circumstances of his travels, he replied in the clearest and most satisfactory manner. The committee is struck with the tone of simplicity and sincerity which reigns throughout his narrative, and which will not admit a doubt of the reality and authenticity of his different excursions ; namely the crossing of the Dhioliba, his route to the east of the districts of Soulimana and Kissi, his navigation on the great river, his residence at Timbuctoo, and his journey across the great desert to the empire of Morocco. Baron Roger had positive information of his departure from 
St. Louis, and of his arrival the following year at Kakondy, whence he sent intelligence to the Senegal of his departure for the interior. Thus the point of his departure is proved: it is the same with the point of his arrival, since he was received, almost immediately on issuing from the desert, by our colleague $\mathbf{M}$. Delaporte, viceconsul-general at 'Tangier. With regard to Timbuctoo, besides the very circumstantial details related by our traveller, and the sketches which he took during his stay, we have a guarantee of another kind in his account of the catastrophe of the unfortunate Major Laing, who had reached this city in 1826. Notwithstanding the variety of rumours relative to this melancholy event, M. Caillié's story agrees with that of a Moor who arrived at SaintLouis in March last, coming from Timbuctoo, and who saw amongst the Touariks the books which had belonged to the Major. Moreover, our countryman resided in a neighbouring house to that which had been occupied by the English traveller, and there obtained exact information, the source of which seems to be incontestable.

The committee is enabled to add further reasons for confidence to the preceding. During the earlier part of his travels, that is, while advancing eastward across the mountains of Fouta-Dhialon, he passed between the towns of Timbo and Labey, and consequently must have intersected the route followed in 1818 by our colleague M. Mollien. Now, such is his description of the mountains, the villages, the aspect of the country, and all the localities, that $M$. Mollien perfectly recognised them in 
the picture drawn of them by M. Caillié. These two travellers then mutually confirm each other; and the result, by the way, is not unimportant to geography.

Our countryman has with so much attention and perseverance recorded his routes, their direction, and the hours of march, that one of our associates has found it easy to form, from his journal, a continued and complete itinerary from Kakondy to the port of Rabat, in the states of Morocco, in which the nature and various accidents of the soil are indicated, such as the mountains, plains, ravines, and forests, the villages and all inhabited places, the rivulets, lakes, and morasses, the torrents, cataracts, fords, wells, and every thing relating both to the running and stagnant waters. Such minute details complete our confidence in the genuineness of this narrative.

We will add that, having interrogated him as to the manner in which he made himself understood by the inhabitants, he told us it was principally through the medium of the Moorish-Arabic, spoken in Senegal, and which he had enjoyed the opportunity of learning in that country ever since 1816. And he replied in fact in this dialect to the questions proposed to him by the committee; he moreover pronounced several words in Mandingo, in a manner conformable to the existing vocabularies.

We were sensible, gentlemen, that it was our duty to lay before you all these considerations, and to insist 
upon them. It now remains for us to make known some of the results obtained, in order that the Society may appreciate the acquisitions that have accrued to science. We are not at liberty here to enter into minute detail; that would be anticipating the publication. A general retrospect is all that the committee consider themselves called upon to offer at present to the public curiosity.

The travels of M. Caillié are connected, in a manner the most useful for perfecting and confirming our geographical knowledge, with those of Watt and Winterbottom to 'Timbo, in 1794; of Major Laing in the countries of Kouranko and Soulimana, in 1822; of $\mathrm{M}$. Mollien in Fouta-Dhialon, in 1818; of Mungo Park to the Dhioliba, in 1\%95 and 1805, of Dochard to Yamina and Bamakou, in 1819; and lastly with the itineraries of the caravans, travelling from Timbuctoo to Tafilet.

No doubts can now remain of the very elevated sources of the Bafing, the principal tributary of the Senegal. Setting out on the 19th of April 1827 from Kakondy, the tomb of Majors Peddie and Campbell, M. Caillié crossed this river at Bafila; he crossed also the main stream of the Dhioliba at a point which very naturally connects itself with the situation assigned by Major Laing to its source. Thence he proceeded to Kankan, a large town in the district so named, enriched by the gold mines of Bourré, aud after some residence there, he continued his journey two hundred miles farther east, beyond 
Soulimana, to the village of Timé, where he arrived on the 3rd of August. He had till then accompanied a caravan of Mandingo merchants, travelling on foot. In this village, he was detained by sickness for five whole months, and attacked by a scorbutic affection, which for a long time endangered his life, and which was induced by the intemperance of the climate and by the violent fatigue he had undergone in traversing the steep mountains of Fouta-Dhialon. This great chain appears to be composed of several stages, and full of torrents and precipices. In this interesting portion of his route, he carefully collected intelligence of the situation of Bamakou, and of its intercourse with the Senegambia, which, it is hoped, will not prove unprofitable.

At Timé commenced another journey northwards; this is the second part of the travels. M. Caillié wished to return to the Dhioliba; he set out on the 9th of January, 1829, and after having seen or passed through more than a hundred villages, and acquainted himself pretty accurately with the situation of Sego, he again saw the river on the 10th of March, at Galia, flowing from the west, and crossed an arm of it to repair to Djenné. All this part is entirely new, as well as the route from the environs of Timbo to Timé.

The third part of the travels is on the great river; M. Caillié embarked on it on the 23rd of March, after a residence of thirteen days at Jenné. He ascended it in a large boat, forming part of a flotilla of merchant vessels. 
It was the season of low water: in some places the river is a mile in width, and in others much narrower; its depth and rapidity are variable. He noted and described, as he went along, the branches and islands, and especially lake Debo (the same which is known and designed upon the maps under the name of Dibbie, but misplaced), and he furnishes particulars, as certain as they are new, concerning the whole course of the stream.

At length he arrived at Cabra, the port of Timbuctoo, on the 19th of April, and the next day entered the town. After he had taken sketches of the dwellings and other edifices of this city, remarked every thing worthy of observation, and acquainted himself with the course of the neighbouring waters, he joined a caravan setting out for Morocco. On the 4 th of May he commenced his journey, with eight hundred camels, loaded with all sorts of merchandise from the interior, and in six days arrived at el-Araouan: there the caravan was increased by six hundred camels, and in eight days more it reached the wells of Télig. All the wells, whether of sweet or brackish water, and all the stations, are carefully noted by $\mathbf{M}$. Caillié, in this journey across the great desert. The season of the burning east winds aggravated the toils and privations of this painful journey. On the 19th of May he left el-Araouan, and it was not till the 29th of June that he reached el-Harib, where the caravan split into several divisions, and on the 23rd of July he entered Tafilet. He rested at length, on the 12th of August, in the very spot where, in the fourteenth century, 
Ben-Batouta cast away the pilgrim's staff, in the city of $\mathrm{Fez}$; he afterwards continued his route with a guide, reached the sea, and on the $17^{\text {th }}$ of the same month, September, arrived at Tangier, where the Consul of France received him, provided for his safety, and succeeded in preserving him from the dangers which he would have incurred, had he been recognized through his disguise.

M. Caillié had provided himself, before his departure, with two compasses, which he used during his travels, and by their aid he was enabled to mark the directions of his route. However imperfect such a method may be, in comparison with geometrical operations and astronomical observations, we must yet congratulate ourselves on having obtained a tracing of the route, and the information of an eye-witness respecting countries, of which we previously possessed only Arab itineraries, reckoned by days' journeys, and for the most part contradictory, vague, and confused. A further proof that he has correctly noted the length of his journeys is, that they perfectly correspond with those distances of places in the empire of Morocco which are the most accurately known.

The success of M. Caillié's enterprize is the more worthy of interest for having been accomplished solely by his own resources, without either participation or assistance from any one. He sacrificed every thing he possessed to supply his wants on these travels. He has achieved every thing possible, and more than could have 
been hoped for with such resources, and he has the satisfaction of having completely succeeded.

If such services are calculated to ensure to M. Caillié the favour of the public and of the government, how powerfully ought they to excite the interest and gratitude of the Geographical Society! It was by the Society's programme, published in 1824, that he was finally determined to penetrate into the interior of an unknown continent. One of our members, being then resident in Se. negal, and finding that he had been for several years animated by a passion for travels, communicated to him a copy of this programme; during the three succeeding years M. Caillié incessantly exerted every possible effort, till he had discovered the means of accomplishing his adventurous design. This is attested by a witness most worthy of credit, our colleague Baron Roger, at that time governor of Senegal. During this period M. Caillié quitted Saint Louis, visited several neighbouring districts, and then fixed on the Rio-Nuñez as the point for his departure; at Kakondy he was fortunate enough to meet with a caravan setting out for the interior, and he skilfully seized the favourable opportunity.

The programme published by the Society in 1824 consists of two parts. The first principally requires accurate particulars respecting Timbuctoo, and the rivers near it, with notices of the eastern countries. M. Caillié has performed most of these conditions. The second part, 
for which the Society offered a special prize, exacted, it is true, astronomical observations ; but it is questionable, whether any one penetrating for the first time into this country, even if provided with the necessary instruments, could possibly fulfil conditions so difficult and dangerous. Who is there but is acquainted with the savage jealousy which the Moors and all those in possession of the commerce of this part of Africa, have from the earliest ages conceived against Europeans; the resistance experienced by Belzoni, when he attempted to pursue this direction; the tragic end of Antonio Piloti, and the sad termination of Major Laing's enterprise?

A. Caillié penetrated as far as Timbuctoo; he went thither by way of Senegambia, as required by the Society. If he has not executed all that it was desirable to have accomplished, he has, on the other hand, made many new and valuable observations, which were not required, upon Fouta-Dhialon, the eastern districts, and the upper part of the course of the Dhioliba; he navigated the river for a month; gleaned intelligence respecting the mines of Bourré, and made other researches that were not required; all which constitutes a sort of equivalent. The discovery of these countries, and the description given of the regions of Baleya, Kankan, and Ouassoulo, are so great an acquisition to geography, that, had he even failed to reach Timbuctoo, he would have deserved a signal recompense. He has the additional merit of having collected a vocabulary of the Mandingo language, and another of the Kissour, spoken at Timbuctoo concurrently with the Moorish, as 
well as of having taken notes of what relates to the customs, ceremonies, productions, and commerce, of the several countries. On the other hand, our programme contains conditions which have been partly fulfilled, since its publication, by the celebrated English travellers, Oudney, Clapperton, and Denham; namely, those which relate to the districts east and E. S. E. of Timbuctoo : we had, therefore, no longer the same motives for requiring their accomplishment.

In awarding, therefore, to $\mathbf{M}$. Caillié the recompense promised to any one who should reach the city of Timbuctoo, and furnish a description of it, the Society will satisfy the general expectation, and be assured of possessing accurate information concerning countries nearly or wholly unknown; it will grant its honourable suffrage to a man who speaks of them, not upon hearsay, but upon the evidence of his own eyes; who, in his simple and unaffected narrative, relates, without any exaggeration, what he has observed, and does not endeavour to excite attention by extraordinary adventures. This is precisely the kind of interest which the Geographical Society attaches to discoveries - that of truth.

It is no small achievement for a man to have broken through the species of enchantment, with which every European appears to have been struck on reaching the mysterious point of the Dhioliba. It is now certain that four or five months are sufficient for a traveller to arrive in Europe from Timbuctoo. Now that the possibility of the 
journey and return is proved by the event, and not left to conjecture, all men devoted to African researches, who may have been diverted from their design by such repeated catastrophes following one another, will take fresh courage and prosecute the enterprize. This constitutes an additional important service, rendered to Science by A. R. Caillié, and for which she will hold herself his debtor, though his success may not entirely console her for the lamented loss of Major Laing.

On a subject so fertile in geographical and scientific developments, it would be easy to expatiate ; but the committee feel the propriety of confining themselves within the limits of their mission; their end is attained if they have produced conviction. They, therefore, feel it necessary equally to pass over in silence the accounts of $\mathbf{J}$. Leon, BenBatouta, and el-Adrisi; and the intercourse of the Portuguese with 'Timbuctoo in the fifteenth century; the travels of Paul Imbert in the seventeenth; the still contested journey of Robert Adams in 1810, and so many other travels which, within the last forty years, have succeeded each other. To act otherwise would be to forget that we address an auditory, who are masters of the principles of every problem in African geography, which, gentlemen is sufficiently attested by the subjects of your three prizes in favour of men determined upon braving every danger to explore this vast continent for the common benefit of science and humanity.

It will be easy, from these premises, to conjecture the 
propositions which the committee has the honour of laying before you; first, that you should grant to $\mathbf{M}$. Auguste Caillié the prize which you have offered to the first traveller who should reach Timbuctoo by way of Senegambia; secondly, that this report should be communicated to their Excellencies the Ministers of the Interior, of the Marine, and of Foreign Affairs.

We cannot conclude this report without paying a just tribute of gratitude to M. Delaporte, Vice-ConsulGeneral at Tangier, for the generous and zealous care which he lavished on our countryman; the Society owes him a particular testimonial of gratitude for having preserved the traveller and his papers.

Baron Ruger, Larenaudière, Amédée Jaubert, Cadet de Metz, J. B. Eyriés, Jomard, Reporter. 


\section{O R R ES P O N D E N E.}

[The following letter is an answer to the first letter written by M. Caillié, on his arrival at Arbate, to the Consul of France.]

GENERAL CONSULATE OF FRANCE AT MOROCCO, To M. Caillié, at Arbate.

Sir,

Tangier, 28th August, 1828.

I have the honour to be a member of the Geographical Society; you will therefore believe with what pleasure I must have perused the letter which you addressed to me, dated the $2 \mathrm{ist}$ of this month, through the medium of the agent of France at Rabat, and how satisfactory to me must be the arrival in safety of such a traveller as yourself, Sir, who may have solved the great problem of the possibility of traversing Africa. It gives me pleasure to believe that you have visited the towns you mention in your interesting letter, and particularly the city of 'Timbuctoo, the rock upon which, for two or three generations past, so many intrepid travellers have been lost; but the proofs which you furnish are not sufficient to confirm my faith: you know how far impostors are capable of deceiving us. Have the goodness, then, to 
supply me with more ample and precise information, that I may make use of it with our government, the patron of great enterprises, and with the Geographical Society, to the gratitude and admiration of which you will have acquired such unexceptionable titles.

I shall write to the agent of France at the place where you have so miraculously arrived, desiring him to give you all the assistance which your situation demands, to receive such declarations as you may wish to make, respecting the difficult and interesting journey you have just completed, and to furnish you with the means of conveyance to Gibraltar, or to me, if you should prefer coming hither.

If, however, you should fear being compromised by a declaration, a report, or other legal statement, address to me a letter for the president of the Geographical Society, which I will convey to him through his Excellency the Minister for Foreign Affairs.

If you should decide to come to Tangier, undertake the journey in such a manner as not to commit yourself, and above all, be circumspect in regard to the religion you have embraced, for the Moors are no triflers on this subject; they are inexorable. Have the goodness, also, to form into a single packet all the daily notes you may have taken during the sixteen months of your arduous journey, and the information you may have collected; request the French agent at Rabat to seal it with his seal, 
and to send it to me by a courier, according to the directions which the agent will receive from me, in order that these valuable and interesting documents, which shall be preserved for you, may not be lost.

I should think myself happy, Sir, to be the first member of the Geographical Society who should enjoy the advantage of embracing an associate who has successfully passed through all the variety of fortune, hazards, and perils of a journey, in which so many have failed; and to give assistance to a countryman under the numerous sufferings which so much exertion and fatigue must have produced.

I shall wait further intelligence from you before I communicate your arrival to those interested in it.

I request you to believe me, with admiration, Sir, your very humble and obedient servant.

Signed Delaporte, Vice-Consul of France, charged with the provisional administration of the general consulate of his Most Christian Majesty in Morocco. 
Extract of a Letter from M. Decaporte, Vice-Consul administering the General Consulate of France at Tangier, to the Commander of the French naval station off Cadiz.

Tangier, 15th September, 1828,

M. Caillié, (Réné-Auguste) has undertaken the painful and dangerous journey from the Senegal and SierraLeone to Tangier, passing through the city of Timbuctoo, and has had the good fortune to surmount all the difficulties, which, as you will judge, are inseparable from such an enterprise.

Chance has thrown him upon an agent of his majesty's government, and a member of the Geographical Society, upon me: I take the best possible care of him; and feel pride in receiving a suffering fellow-citizen, the first European who has acquired for our country a knowledge of the city of 'Timbuctoo, the search after which has cost so many lives, and so much treasure.

M. Caillié presented himself to me under the costume of a mendicant Dervish, a character which $I$ assure you he did not belie: during his journey he feigned himself a follower of Mahomet. If the Moors had suspected him of being with me, or at the consulate, he would have been a lost man; I entreat then, from your humanity, your love and admiration of great enterprises, assistance in saving this intrepid traveller, whose name will soon be- 
come celebrated, by sending to me, if at present disposable, one of the vessels under your command, or if you think it preferable, by coming hither yourself. You would land here. M. Caillié would adopt the accoutrements of a sailor, or personate an officer; he would mix with the attendants on the equipage, or with the staff; he would reach your ship, and be saved. It would be grateful to you and to myself to have co-operated in the protection of this remarkable traveller.

The English would not hesitate an instant to receive on board one of their sovereign's ships of the line a countryman of such merit. It was lately published at Gibraltar, that Major Laing had arrived there in the costume of an Arab; a king's cutter was immediately placed at his disposal, to transport him to London; instead of Major Laing, it proved to be M. Linc; the similarity of name caused the mistake, but the cutter had been dispatched to its destination.

Will you oblige me by an answer, and by informing me whether it will be in your power to render to France, if I may so express myself, and to the Geographical Society of France, the service which $I$ request of you in their name, on behalf of $M$. Caillié; that if necessary I may seek other means of restoring him to his country.

I am, \&c.

Signed Delaporte. 
Extract of a Letter from M. Delaponte Vice Consul of

France to M. Jomard Member of the Institute.

Tangier, 27th September, 1828.

M. Caillié whose name I have read in one of the numbers of the Bulletins of the Geographical Society, has traversed Africa, from Rio-Nuñez to Tangier, passing, on his route, through Timbuctoo. He will embark to-day on board a king's schooner for Toulon, where he will arrive without resources. I hope the Geographical Society will take charge of this traveller, who, I believe will do it honour. He has crossed Africa as a mendicant; as such he appeared at my door: but I received him, I paid him every possible attention, and think myself happy in being the first Frenchman who has embraced him.

He will present himself to you, and will communicate to you the materials of which he is the bearer : he proposes to intrust you with the task of editing them*.

He deplores the want of means which deprived him of the advantages of a brilliant and distinguished education; but he consoles himself under this misfortune, in the happiness of being the only European who has conquered the great difficulty, and of having enriched the reign of his Majesty Charles $\mathrm{X}$ with an enterprise which has baffled so many travellers and scientific men.

* M. Jomard's share in the publication is confined to the itinerary, the maps and the geographical discussions, the division, and the general superintendence of the work. 
Have the grodness to present him to the President of the Society, to recommend him to all its members, and to pay him the attention which he deserves.

I embrace you with all my heart and subscribe myself with affection, esteem, and consideration, \&c.

Signed Denaporte.

Exlract of a Letter from M. Decaporte to M. Jomard.

Tangier, October 3rd, 1828.

I have introduced to you the French traveller Caillié, who has crossed the burning deserts of Africa, and there contracted the scurvy, which has eaten into the bones of his palate. If God, who has been his protector as far as Tangier, should preserve his health, he will reach you two or three months' hence. Instead of confused itineraries, put together from hearsay, and taken by stealth, such as those which for several years past $I$ have furnished, he will present himself to you with authentic labours, with documents, and materials taken on the spot, of which he will request you to superintend the compilation. Do not refuse your assistance.

This traveller has deserved the prize for the journey to Timbuctoo hy the route of Senegal, because he set out from St. Louis to reach Tangier; he is also entitled to that for the most important discovery in geography, as he will prove by his work : they cannot be refused to him.

Signed Delaporte. 
Extract of a Letter from M. Caillié to M. Jomard.

Lazaretto at Toulon, October 10th, 1828.

SiR,

My zeal for geographical discoveries induced me to undertake, in 1827, a journey into the interior of Africa, to visit the city of Timbuctoo, the object of anxious research to Europe, and which has proved fatal to so many illustrious travellers. Being unable to obtain a mission from the French Government of the Senegal, I determined to undertake the journey with my private resources : for this purpose then I realized all my effects and made preparations for my expedition.

On the 19th of April 182\%, I quitted Kakondy upon the Rio-Nuñez, in company with Mandingo merchants going to the Niger : the Arab costume and the religion of the Pro. phet, which I adopted, smoothed all difficulties; I traversed without obstacle the elevated mountains of the Fouta-Dhialon, the Kankan and the Ouassoulo. I resided five months at Timé on account of severe illness. This village is inhabited by Mahometan Mandingoes; and is situated in the southern part of the Bambara. Early in January 1828, I continued my route; I visited the island and town of Jenné, and embarked on the Niger for Timbuctoo, where I arrived after a difficult navigation of a month : I resided in that town fourteen days, acquired all the information in $\mathrm{my}$ power respecting it; studied the manners and customs of the inhabitants, and the commerce and resources of the country; and thence travelled northwards to accomplish 
my return by the great desert. I passed through el-Araouan; after two months of the most painful privations, I arrived in the Tafilet, and continued my route by $\mathrm{Fez}$ and Rabat to Tangier, where M. Delaporte, the French ViceConsul in that town, lavished upon me all the assistance of which I stood so much in need. I soon after embarked on board the king's schooner La Légère, which conveyed me to Toulon, where I now am, convalescent, and without means of support, having exhausted my all in a journey of sixteen months.

I am, \&c.

signed A. Caillié.

Extract of a Letter from M. A. CAILIIE to the President of the Geographical Society.

Toulon, 10th October, 1828.

Sir,

1 had the good fortune, in 1824, to take a journey among the people who inhabit the smiling banks of the Senegal : from that period I projected an attempt to explore central Africa, to visit the towns of Jenné and Timbuctoo, in hopes if possible to surpass the English who had so far outstripped us in this career. Having been unable to obtain a mission from the Government of the Senegal, I determined to part with all my resources, convinced that on my return, the services 1 might have rendered would be recognized by Government; I realized then the small means which I possessed, the fruits of economy, and made preparations for my departure. On the 19th of April, 182\%, I quitted Kakondy upon the Rio-Nuñez, in 
company with a caravan of Mandingo merchants going to the Niger. Thanks to the Arab costume and to the religion of the country which I outwardly embraced, the numerous difficulties attendant on this laborious journey were overcome; and to this disguise I owe the success of my expedition. I crossed without obstacle the high mountains of the Senegambia, the countries of Baleya, Kankan, and Ouassoulo. I was compelled to reside five months at Timé, a village of Mahometan Mandingoes, situated in the southern part of Bambara, being detained by a severe illness which had nearly proved fatal. On the 9th of January, 1828, I was able to proceed on my journey. I visited the island and town of Jenné; and afterwards embarked upon the Niger, on board a vessel of sixty tons burden going to Timbuctoo, where I arrived after a month's tedious navigation. This town is situated five miles to the north of Cabra, in a plain of quicksand, where nothing grows but stunted shrubs: I resided there fourteen days. I inspected the town and took a sketch of it; I studied the manners and customs of the inhabitants, and the commerce and resources of the country; then taking a norithern direction to cross the great desert, I arrived at el-Araouan. This town is six days' journey north of Timbuctoo: it is the emporium of salt which is exported thence to Sansanding and Yamina, and is situated in a country still more sterile than even that about 'Timbuctoo. Not a shrub is to be seen; and camel dung is used for fuel. The burning east wind which constantly prevails renders this a very disagreeable abode. I continued my route northwards, and reached the Wells of Telig, after 
eight days' journey from el-Araouan. Here we quenched our thirst and proceeded north north west into the heart of the desert : here the soil is most barren, composed of moving sand and rocks of grey quartz veined with white; there is also a little granite. After two months' journey in this horrible country, I reached the Tafilet, a small district forming part of the empire of Marocco, and passed through Fez, Mequinaz, Rabat, and Tangier, where I was received by M. Delaporte, Vice-Consul of France, who lavished upon me all the assistance of which I stood so much in need. I soon after embarked in the king's schooner La Légère, which conveyed me to Toulon, where I have been twenty-two days in quarantine. I am convalescent and without means of support, having exhausted all in an arduous journey of sixteen months.

I am, etc.

Signed A. CaILlí́.

After having heard the preceding communications at the mecting of the 17 th of October, the central committee of the Geographical Society decided unanimously, that a first pecuniary indemnity should be immediately sent to $M$. Auguste Caillié, and that extracts from these letters should be printed in a supplement to the 66 th Bulletin. 
Letter of M. Delaporte to the President of the Geographical Society.

Mr. President,

Tangier, 3rd October 1828.

To communicate to you that a European has just conquered in Africa, for the Geographical Society, a vast extent of territory, is to impart good news both to you and the Society; but the announcement that this European is a Frenchman will render it still more agreeable.

One of our countrymen, M. Auguste Caillié, has acquired for the Society all the territories situated between Rio-Nuñez, (Sierra Leone) and Tangier, that is to say between the Ocean and the Mediterranean. He has visited the towns of Kankan, Jenné, Timbuctoo, and Araouan. He sojourned fourteen days at Timbuctoo. His house was within a few doors of that which had been inhabited by the unfortunate Major Laing. He has employed sixteen months upon this labour and in collecting the materials with which he has enriched his wallet. Nothing disheartened him, neither refusal, nor disgust, nor fatigue, nor danger; his vocation, as he has frequently repeated to me, demanded that he should cross Africa; he followed it and has solved the problem that a European may traverse this continent, a problem, the impossibility of which appeared all but demonstrated. $\mathrm{He}$ travelled without ostentation; and I saw a mendicant Dervish, with his 
leathern wallet at his back, seated at the threshold of my door, and extending to me, not the hand of indigence, not the hand of that misery of which he bore the livery, but of a compatriot, addressing himself to a servant of the King of France, and requiring his protection. He obtained it, Sir ; it was afforded to him by me, in the character of temporary administrator of the General Consulate of France, to the utmost of my power; and thanks to the co-operation of the Chevalier de Luneau, commander of the French naval station off Cadiz, who had the complaisance to send me a king's ship, I have saved the traveller and his papers. Lieutenant Jollivet received M. Caillié on board the king's schooner La Légère, which he commands ; and on the 28th of last September he set sail for Toulon where he will perform his quarantine.

Two departments, those of Foreign Affairs and of the Marine, have contributed to restore a Frenchman to his native country, and to acquire for the Society over which you preside a modest traveller, whose enterprise will reflect lustre upon it.

M. Caillié, whose health has been affected by the fatigue and labour he has undergone, embarked with a fever. It is to be hoped that it will have no ill consequences, and that he will land at Toulon in health and safety.

If M. Caillié does not possess the brilliant qualifications or the education of our modern travellers, he has the 
ingenuousness and frankness of the honest traveller of the olden time who has given us so much interesting information concerning India; if he is not the Amédée Jaubert of Asia, he will be the Marco-Polo of Africa; and he will have had the merit of achieving, at his own expense and without assistance, what others have been unable to effect with ample treasures.

After his quarantine, he will repair to Paris, where he proposes to request the assistance of the Chevalier Jomard, vice-president of the Central Committee, of the Society, in editing the rich materials in which alone his fortune consists. To bespeak, Sir, your interest in favor of this traveller, is to recommend him to all the members of the Geographical Society, to which I have the honour to belong.

$1 \mathrm{am}, \& \mathrm{c}$.

Signed Dexaporte.

Letter from M. Jomari to M. CaIllís.

Paris, 18th October, 1828.

Sir,

I have received, with all the interest it deserves, the letter which you have addressed to me respecting your Travels in the interior of Africa. You have justly thought that no one could be more deeply concerned than myself in the success of your journey, and I have not lost a moment in communicating to the Geographical Society the contents of your letters and those of M. Delaporte. 
After attending to the reading of them with marks of the most lively satisfaction, the Society decided that, while the effect of the representations $I$ am about to make to the government is in suspense, the sum of five hundred francs should be transmitted to you to relieve your immediate wants, and to assist you in your journey to Paris.

We think, Sir, that it will conduce to your interest to make the best use of your time which your situation and health will permit, in committing to paper all your recollections while still fresh in your memory; and particularly that you should note, with exactness, the hours or the days of march, the bearings you followed, and whatever from its nature is liable to be forgotten, as the names of places and proper names in general.

I offer you, Sir, all the service in my power ; dispose of my feeble interest; and, above all, take the repose which is so necessary to the re-establishment of your health after such long continued fatigue.

I have the honour to be, \&c.

Signed Jomar D.

Extract of a Letter to the President of the Academy of Sciences.

Paris, 18th October, 1828.

Mr. President,

I have the honour to communicate to the Academy of Sciences the contents of the letters which I yesterday 
received from M. Delaporte, Vice-Consul of France, administering the general Consulate at Tangier. A Frenchman has accomplished the journey to Timbuctoo. He has been fortunate enough to traverse almost the whole of Africa, north of the Equator, from the Rio-Nuñez, in about $10^{\circ} 15^{\prime}$ north latitude, to the Straits of Gibraltar, and is arrived in health and safety at the Consulate at Tangier, after having crossed the Atlas between Tafilet and Fez, and travelled during sixteen consecutive months.

As he is the first European who has succeeded in the journey to Timbuctoo, and returned from that place, I doubt not, whatever the results may prove for which the sciences may be indebted to him, that the Academy will learn the news with a lively interest.

On the 19th of April, 1827, M. Caillié set out from Kakondy on the Rio-Nuñez, whence he travelled easterly nearly three hundred leagues, to Timé, beyond the great river Dhioliba. He embarked upon it near Jenné, and after a month's navigation reached Timbuctoo, in April last. After a residence there of several weeks he pursued his route to the north and N. N. W. Seventy-five days were occupied by his journey from this capital to the Tafilet, across the Sahara, or Great Desert, amidst the severest fatigues and most painful privations.

The first part of his journey coincides with that of some English travellers*. He subsequently crossed the different stages of the chain of mountains of the Fouta-

* It is the line which Watt and Winterbottorn took in $\mathbf{1 7 9 4 .}$ 
Dhialon, in the midst of which he crossed the route taken by Mollien, and perhaps the Senegal near its source.

As he travelled little more than twelve geographical miles a day, he had time for attentive observation. $\mathrm{He}$ traversed the countries of Belia, Kankan, and Ouassoulo, which we barely know by name; and finally, before arriving at Jenné, had an opportunity of seeing Bamakou, Yamina, Sego, and Sansanding*.

Such is a sketch of the journey which M. Caillié has just completed, extending to about fifteen hundred leagues, a thousand of them through regions almost unknown. We may at once infer from it, that Timbuctoo lies much nearer to the ocean than it is marked upon all the maps. His marches confirm the conjecture which I have already brought forward that this great town is not far from the seventeenth degree of north latitude.

I have the honour to be, \&c.

Signed Jomard.

Letter of the Presidents and Secretary of the Geographical Society, to His Excellency the Minister of the Interior.

Paris, 20th October, 1828.

\section{Monseignedr,}

By the letter which Your.Excellency did us the honour

* He passed considerably to the east of these towns. 
to address to us, dated the 2nd of April last, you manifest a desire to receive information of any intelligence which may reach us upon the subject of the enterprises formed by the Society, and especially upon the discoveries which relate to the interior of Africa.

We consider it our duty to communicate, without delay, to Your Excellency, the news which we have received within the last two days. A Frenchman has been fortunate enough to penetrate into central Africa. He even appears to have resided for some time in the city of Timbuctoo. Having quitted in 18\%7 the banks of the Rio-Nuñez, he travelled eastwards to beyond the Dhioliba, crossing the high mountains of the upper Senegambia. He afterwards followed the course of that great river, and embarked upon it opposite to Jenné. After a month's navigation he landed at Cabra, the port of Timbuctoo. Having made all the observations in his power, he entered the great desert of Sahara, across which two months and fourteen days toilsome travel brought him to the Tafilet, whence he proceeded to Tangier. There, M. Delaporte, his Majesty's Vice-Consul, administering the general Consulate, received him, relieved his immediate necessities, and procured him a passage to France on board one of the vessels of the state.

This interesting traveller is named Caillié. He had been at the Senegal since 1824 : it was in the month of 
April 1827, that he repaired to Kakondy upon the RioNuñez; where he joined a caravan of Mandingo merchants. This situation is the more deserving of notice, as before his embarkation he had undergone a serious illness which detained him five months to the south of Jenné. The total length of his route is from twelve to fourteen hundred leagues, a thousand of them through regions nearly unknown.

Such is the substance of the letters we have just received from the traveller. The reception he experienced from the Vice-Consul, a gentleman well vers. ed in the languages and relations of Northern Africa, has determined that of the Geographical Society, which has hastened to present him with marks of encouragement.

We hope, Monseigneur, that this news will interest Your Excellency, that you will honour this traveller with marks of your approbation, and that you will recommend him to the Minister of the Marine, that he may obtain from him the assistance of which he stands in need to facilitate his journey to Paris. All his resources have been exhausted in a laborious journey of sixteen months. He is the first European, who, after having penetrated into this part of central Africa, has returned in health and safety. The Geographical Society takes credit to itself for having directed the attention of travellers of all countries to the interior of this continent; but it rejoices to find 
that it is a Frenchman, who has first attained the glory of success.

We are \&c.

Signed Baron Cuvier, President of the Society; Viscount Srmḱon, Vice-president; Jomard, Vice-president of the Central Committee; DE LARENAUdì̀E, Secretary.

Letter of the Presidents and Secretary of the Geographical Society, to his Excellency theMinister of the Marine.

Monsejgneur,

Paris, 20th October 1828.

A French traveller, M. $\Lambda$. Caillié has just arrived at Toulon on board the king's schooner La Légère, after having brought to a happy termination a difficult and painful journey in the interior of Africa, from Rio-Nuñez to Tangier. It appears that he has resided for some time in the town of Timbuctoo. This arduous journey has exhausted all his resources, and his health is impaired by long continued fatigue. His Majesty's Vice-Consul at Tangier recommends him to the Geographical Society, that it may procure for him from the government, the means to proceed to Paris. As this is the first European traveller who has accomplished such an enterprise, we think ourselves entitled, Monseigneur, with confidence to solicit your interest in his behalf, and to request for 
him the support of your benevolence. Thensociety entreats you to have the goodness to procure for him the means of conveyance to Paris.

We are, \&c.

Signed Baron Cuvier, President of the Society; Viscount Srmḱon, Vice-president ; JoMARD, Vice-president of the Central Committee; De Larenaudièri, Secretary.

Mr. John Barrow, to M. Jomard.

Sir,

I have the honour to address myself to you on a subject in which $I$ am persuaded you take as much interest as myself-the progress of the discoveries in Africa.

I see by the supplement to the 66 th Bulletin publish ed by the Geographical Society of Paris, that a Frenchman, of the name of Caillié, has succeeded in reaching the city of Timbuctoo; and that M. Delaporte, Vice-Consul at Tangier, observes in his letter to you, announcing the arrival of M. Caillié, that that traveller consoles himself for the fatigues which he has endured by the reflection that he is the only European who has hitherto succeeded in happily accomplishing an enterprise in which so many brave travellers have fallen.

Far be it from me to conceive the idea of detracting 212 
from the merit of this bold and adventurous traveller, or to blame the just pride which he feels at having brought his enterprise to a happy termination; but the justice which is due to the memory of another traveller, who has perished by the barbarous hand of an assassin, calls upon me to shew you, Sir, that M. Caillié is neither the only, nor the first European who has visited Timbuctoo.

The late Major Laing was the first who reached Timbuctoo, as I shall prove by the most indisputable authority-namely his own hand-writing, and that of his servant, who is now at Tripoli. In a letter, dated 'Timbuctoo, September 21, 1826, addressed to the Consul, Mr. Warrington, now lying before me, the Major says that he arrived in this city on the 18 th of the preceding month; that he intended to quit it the day following the date of his letter, that is to say, on the $22 \mathrm{nd}$ September and to proceed on the road to Ségo : he then enters into many details relative to this city, and gives a great number of curious documents which he had collected on the subject, and other materials, which will without doubt be one day published.

He accordingly left Timbuctoo, on the 22nd September, with a small caravan, having only one Arab servant ; on the third evening he was joined by several Arabs belonging to the caravan, and afterwards basely massacred. It happened that the above-mentioned letter, written from Timbuctoo, was in the possession of his servant. His baggage was entirely pillaged, and his journal and numerous papers carried off; but we have still hopes that 
they will be recovered. The servant has undergone the most rigorous examination; he is firm and consistent in all his answers; and I regret to say that there is great reason to suppose that this enterprising traveller fell a victim to the traitorous and barbarous Bello, who behaved so scandalously to Captain Clapperton.

I therefore hope from your justice, as a man devoted to the sciences, and particularly to geography, and as President of the Central Committee, that you will give the same publicity to this communication as has been given to the fortunate result of the meritorious enterprise of $M$. Caillié.

I have the honour to be,

Sir,

Your very obedient servant, JOHN BARROW.

Extract from the Answer of M. Jomard to Mr. Barrow.

$$
\text { Paris, } 31 \text { October, } 1828 .
$$

\section{SIR,}

Although a stranger to the letter which forms the subject of your appeal, I should never consent to participate, even indirectly, in an assertion contrary to truth, or 
to the reputation of the courageous traveller, whose interests you justly defend. No one is less accessible than myself to impressions exclusively national, and it is on behalf of humanity in general that $I$ am devoted to the cause of science and its indefinite progress. I should, therefore, have sincerely rejoiced in being the first to make known in France the return and success of Major Laing, as I was fortunate enough to do in regard to Captain Clapperton and Major Denham on their arrival. You must be aware, Sir, that it was I who announced to the French public the labours of these intrepid adventurers, who first published their valuable Discoveries in Central Africa, and paid legitimate homage to the memory of Dr. Oudney. With respect to Major Laing, I long questioned and withstood the premature rumours of his death, and exerted myself to point out the contradictions that pervaded the accounts circulated both in Africa and Europe; nothing, indeed, had yet persuaded me of the reality of this catastrophe, and your letter alone, Sir, could oblige me to give entire credit to this distressing intelligence, so ardently did I desire to be informed of Major Laing's success, and to have the pleasure of proclaiming it, and of contributing, however feebly, to his renown. Major Denham may have acquainted you with the reception which he experienced from me at Paris ; and told you how happy I esteemed myself in embracing this brave officer, and in conversing with a man who had ten times courageously hazarded his life, in order to penetrate as far as possible in an unknown continent. 
Now, Sir, these are the very expressions which form the subject of your appeal: " $\mathrm{He}$ (M. A. Caillié) is the only European who has hitherto succeeded in happily accomplishing an enterprize in which so many brave travellers have fallen."

You see, Sir, that the matter in question is the fortunate return of the traveller to his country, and not the discovery of Timbuctoo. The merit of having first visited that city is not ascribed to him. Thus, after the death of Dr. Oudney, his more fortunate companions, Clapperton and Denham, again reached their native land: it might then be said, on their return to England, that they were the first Europeans who had come back from Bornou, and brought this enterprise to a successful termination, and that without detracting in the least from the Doctor's wreath of glory. You will then do justice, Sir, I make no doubt, not only to me, but to M. Delaporte, Vice-Consul of France; and you will have no difficulty in acknowledging, that no one has had any intention of depriving your countrymen of the honour due to them. I take credit to myself for having contributed to establish it as a principle in the Geographical Society, that traveliers of all nations are equally entitled to its attention, that its rewards belong to all, whatever may be their nation; in short, that there is no distinction in the feelings of this Society towards foreigners and denizens.

Permit me, Sir, to deplore with yourself the sad event related in your letter; however, several circumstances 
appear still to leave some small room for doubt; I hope my incredulity may be justified by the event. But, if the catastrophe is certain, it is yet deroutly to be wished that the journal of his travels may be recovered, or that his servant may be able to furnish some information that can be depended upon; also, that the curious documents, which you mention as being in your possession, may be published as soon as possible. We shall soon, I hope, be favoured with the documents brought home by Clapperton's servant, Lander, and I shall not then be behind-hand in appreciating the merit of this new victim to the cause of science. Allow me here, Sir, to add one remark : had it devolved upon me to make a catalogue of the Furopeans who have reached the city of Timbuctoo, I should not have overlooked several individuals who appear to have visited it; I should even probably have mentioned Robert Adams, though his travels have been called in question, and opinions, as you know, are still divided upon them. Neither would M. Delaporte have failed to cite them, had this been his object: but his intention was simply to announce the fortunate return of the traveller, after having crossed the Great Desert; a happiness neither reserved for Hornemann, Park, Oudney, the unfortunate Laing, nor for so many other lamented victims.

It only remains for me, Sir, to congratulate myself on the opportunity you have afforded me for expressing my real sentiments as to what should constitute the object of all geographical discoveries, that is to say, usefulness and the increase of human happiness. I am equally gra- 
tified in the opportunity of expressing to you, individually, the high esteem which I profess for scientific men and travellers of your nation. With these sentiments I beg you to believe me, \&c.

Signed JomaRD.

Letter from His Excellency the Minister of the Interior to the Presidents and Secretary of the Geographical Society.

Sir,

I have received the letter you did me the honour of writing to me, and in which, in answer to that which I had addressed to you on the second of April last, you communicate to me the most recent intelligence that has reached you from the interior of Africa. I have read with real interest the details relative to the travels of the Sieur Caillié, the first French traveller, you observe, who has returned without danger and even with success, from such an enterprise. I see with pleasure that the Geographical Society has conferred on him marks of satisfaction; for my part, Gentlemen, in compliance, with the wishes you conveyed to me, I have written in his favour to His Exc. the Minister of the Marine. I have requested that minister will have the goodness to provide the Sieur Caillié, with the means of repairing to Paris; and the better to 
ensure his attention, I transmitted to him a copy of the succinct narrative with which you favoured me, and for which I thank you.

Please to accept, \&c.

signed Martignac.

Letter from the Presidents and Secretary of the Society to M. Delaporte.

Paris, 3rd October 1828.

\section{Vice Consur,}

In a letter from Toulon, dated 10th October, M. Auguste Caillié informs us of a journey he had just accomplished in the interior of Africa, and pays you a just tribute of gratitude for the generous manner in which you received him. In answer to your letter of the $3 \mathrm{~d}$ instant, confirming the circumstances of this journey, we hasten to address to you the thanks of the Geographical Society for the additional particulars it contains, and especially for the attention which you paid to our countryman. In thus fulfilling the duties of humanity, you have saved the life of an estimable and courageous traveller, the first amongst Europeans who has returned from Central Africa by way of Morocco.

'The Society has already strongly recommended $\mathbf{M}$. Caillié to the Ministers of the Marine and the Interior, and 
immediately forwarded to him at Toulon a first indemnity, to supply his urgent necessities.

We have the honour to be, \&c.

Signed Baron Cuvier, Jomar d,

De Larenaudière.

Letter of His Exc. the Minisler of the Marine.

Paris, 11th November 1828.

\section{Gentlemen,}

You have done me the honour of recommending to me the Sieur Caillié who has just accomplished a journey to Timbuctoo and several other parts of Central Africa, and is recently arrived at Toulon.

The Minister of the Interior has also written to me in favour of M. Caillié. My answer to His Exc. is that it belongs to his office to provide this traveller with the assistance which seems to be most necessary to him, and that I shall with pleasure concur in any ulterior measures that may be adopted by the department of the interior, to make a suitable compensation for the labours and zeal of M. Caillié, whose claims upon the favour of government I fully appreciate.

Permit me, \&c.

Signed Baron Hyde De Neuvilet. 
Extracts from the Minutes of the Meeting of the 21 st November 1828.

M. Jomard gave notice that M. Auguste Caillié, present at the meeting, wished to offer his thanks to the Society; he then gave some account of the information derived from the travels, and announced that he had been able from the journal to draw a complete itinerary from Rio-Nuñez to Tangier, by 'Timé, Jenné, Timbuctoo, Tafilet, and Fez. He proposed that a committee of five members should be appointed to take the papers into consideration and make their report before the general meeting, in order that the public may be speedily enabled to appreciate the labours and observations of this interesting traveller. The proposition was unanimously adopted, and a special commission composed of Messrs. Eyriès, Amédée Jaubert, Larenaudière, baron Roger, Cadet de Metz, and Jomard, appointed to report to the meeting upon the travels and papers of M. Caillié. The central commission will hold an extraordinary meeting to receive this report. 
Letter from the President and Secretary of the Society, to their Excellencies the Ministers of the Marine, of the Interior, and of Foreign Affairs.

Paris, 28th November, 1828.

Monseigneur,

The Geographical Society, after having attentively investigated the efforts and observations of M. A. Caillié in the interior of Africa, has aknowledged him deserving of the reward promised to the first traveller who should reach the city of Timbuctoo, setting out from Senegambia, and has decided that the annexed report should be communicated to Your Excellency. We hasten, Monseigneur, to address to you a copy* in behalf of M. Caillié, and we deem it superfluous to recommend him again to your favour. Perhaps Your Excellency may think it advisable to lay before His Majesty a statement of his services.

We are, \&c.

Signed Baron Cuvier, President; Viscount Srméon, Vice president; Girafo, President of the Central Committee; Jomard, VicePresident; De Larenaudière, General Secretary.

See the report page 451 . 
Letter from Mr. John Barrow to M. Jomard.

London, 1st December, 1828.

Sir,

I have received your obliging letter of the first of November and that of the 20th, to which you have had the goodness to add printed copies of our correspondence on the subject of the two African travellers therein mentioned. I beg you to accept my very hearty thanks. The explanation you have kindly given in your first letter is perfectly satisfactory, and of a nature to convince me that I was under a mistake, and that I had confounded M. Caillié's happy return with the successful accomplishment of his enterprise. I have long delayed thanking you, that I might be enabled at the same time to send you a copy of the map, \&c.

Signed JoHn Bar row.

Letter of His Excellency the Minister of the Marine to M. JomarD.

Paris, 2nd December, 1828.

While the definitive recompense which $\mathrm{M}$. Caillié may be entitled to expect, on account of the courageous enterprise which he has recently accomplished, remains in suspense, I have proposed to the King to grant to this traveller a provisional indemnity of three thousand francs, 
payable from the funds of the Senegal. His Majesty has been graciously pleased, by a decision of the 30th of November, to accede to my proposition. I have thought that it would be agreeable to you to be informed of this act of royal beneficence, which I congratulate myself as having been the instrument of obtaining.

Receive, \&c.

Signed Baron Hyde de Neuville.

Letter of His Excellency the Minister of the Marine to M. JomaRD.

Paris, 10th December, 1828.

I hasten to announce to you that upon my proposition, the King has deigned, by an ordinance of this day, to create $M$. Caillié a Knight of the Legion of Honour : I request you will have the goodness to announce it to him. I shall be happy to see him to-morrow, Thursday the 11th of December, between the hours of eleven and one, to communicate this intelligence to him personally.

Be pleased to accept, \&c.,

Signed Baron Hyde de Neuville. 
Letter of His Excellency the Minister of the Marine, to Baron Cuvien, President of the Geographical Society.

Paris, 11th December, 1828.

You have transmitted to me, in the name of the Geographical Society, a copy of the report of the special commission charged to draw up for the society an account of the travels of M. A. Caillie to Timbuctoo and in the interior of Africa. I have the honour to thank you for the communication of this interesting report.

I have learned with pleasure that the Society has judged M. Caillié deserving of the recompense promised to the traveller who, setting out from Senegambia, should penetrate to Timbuctoo.

Considerably as my department has already contributed to the formation of the fund appropriated to this object, I have proposed to the King to grant to $M$. Caillié, from the colonial funds, a special indemnity of three thousand francs, the allowance of which $I$ have directly announced to M. Caillié.

A favour of still higher value has since been decreed to this traveller; by an ordinance of the 1oth of December, issued upon my report, the King has named him a Knight of the royal order of the Legion of Honour. 
I congratulate myself in having to acquaint the Geographical Society with these acts of royal beneficence, which I have joyfully seized the opportunity of recommending in recompense for M. Caillié's devotedness.

Be pleased to accept, \&c.

Signed Baron Hyde de Neuvil le.

\section{Extract from the Minutes of the General Meeting of the 5th of December, 1828.}

M. Jomard, the organ of the Committee charged to draw up an account of the results of M. Caillié's travels, read the report, which was listened to with the most lively and intense attention. After having successively explained all the reasons upon which the conviction of the Committee was founded, and especially the agreement which subsists between the accounts of this traveller and those published by such of his predecessors as are the most accurate and most deserving of credit; after having announced that M. Caillié's journal contains an itinerary continued without interruption from Rio-Nuñez to Tangier; the reporter delivered a sketch of the results of the Travels sufficient to excite, but not to satisfy the curiosity of the audience. He enumerated the principal places which our countryman visited during a journey of seventeen months, and of about three thousand miles. We shall only cite his embarkation at Jenné on the Dhioliba (vulgarly called the Niger), his navigation from thence to Timbuctoo, during an entire

VOL. II.

$2 \mathrm{~K}$ 
month in the season of shallow water; his residence in this town, and his subsequent journey across the great desert, during two months and a half, to the kingdom of Morocco and to Tangier. There M. Delaporte, Consul of France and a member of the Geographical Society, received our countryman, lavished upon him all the attentions which his ill-health and exhaustion demanded, after his escape from the dangers of the climate and the perils of so long and arduous a journey.

The report was warmly applauded; and, in conformity to the conclusions of the Committee, M. Caillié was introduced, and received from the hands of the President the recompense offered to his generous self-devotion, that is to say, the produce of a susbcription opened by the Society in behalf of the person who should first succeed in penetrating to rimbuctoo by the way of Senegambia, and in furnishing a description of that town.

Letler from Ris Excellency the Minister of the Interior.

Paris, 5th December, 1828.

\section{Gentlemen,}

I have received the letter which you did me the honour to write on the 29th of November last, and with it a copy of the report made to the Society upon the travels of M. A. Caillié in the interior of Africa. 
I shall examine with interest what it may be in my power to do towards fulfilling the wishes you express in - favour of a traveller, who has executed an enterprise of the great importance of which, in its relation to science, and our intercourse with countries, hitherto, and even still, so imperfectly known, I fully appreciate, as the Minister of the Marine has done.

Be pleased to accept, \&c.

Signed Martignac.

Death of Major LAing.-Literal translation of a Letter written at St. Louis by a Moor of Timbuctoo, and addressed to M. Jomard by M. Prosper Gerardin.

Know that Chems, chief of the tribe of Darmancours, has told me that he has received a letter from Saleh, son of our Iman and of our Cheyhkh (at Tischit), relating to the christian who went to Gadamès. From this town he went towards Touat, then he proceded towards the tribe of the Cheykh Moctar (chief of the Kountas, to the east of the kingdom of the Dowiches). In consideration of a thousand drachms of gold, the people of this tribe accompanied him to Timbuctoo, where they arrived after a journey which continued seven days; afterwards they left him. 
This white man remained some days at Timbuctoo; then he quitted it. He was met by the Moors who are called Berabiches. These killed him, stole his money, and left behind the books which he possessed.

Saleh says that, if the christians wish for these books, they have only to send some one to him, and that he will restore them.

The Berabiches are the Moors who inhabit the environs of 'Timbuctoo and Arawane.

The King of Timbuctoo is named

\section{Narrative of a Moor from Timbuctoo (communicated by the Baron Roger.}

St. Louis, September, 1828.

On my way hither from my own country, I passed through Timbuctoo, when I learnt that a white man, who had resided there some days, had been murdered on his way to Ségo; and the circumstances of that unfortunate event, as related to me, in that town, are as follows :

This European, who came from Tripoli, and expressed a desire to proceed to the Senegambia, travelled with a Jew of Barbary, who acted as interpreter; he was attended by four black servants, and possessed nine camels 
laden with provisions and merchandise. He had arrived within a few days' journey of 'Timbuctoo with his caravan, when he was joined by another, composed of Moors of Tuat or Tuaris. They first demanded presents of him, and then invited him to barter. The Englishman (who is supposed to be Major Laing) consented, aud trafficked with this tribe : "but, during the night, they burst into his tent and attacked him. The white man and his servants defended themselves bravely: though wounded in the arm, the traveller succeeded in escaping on one of his camels: he was rejoined soon after by one of the blacks, who brought back two others; they fortunately reached Timbuctoo and took refuge there. But the Tuaris pursued them, and required of the King to surrender to them the white man who had killed several of their companions. The unfortunate man was obliged to flee from his persecutors: in vain he took a contrary course to deceive his pursuers and escape to Ségo; he was overtaken by the villains and put to death.

I could have easily obtained from the Tuaris the books which belonged to this European; but I durst not, lest I should be suspected of having been concerned in his murder. 


\section{LONDON:}

Printed by G. SCHUlze, 13, Poland STREeT. 



